Rhode Island College

Digital Commons @ RIC

Master's Theses, Dissertations, Graduate

Master's Theses, Dissertations, Graduate Research and Major Papers Overview

Research and Major Papers

$5-2-1985$

\title{
Cross-Cultural Patterns of Disability in non-Western Societies
}

Sara W. Weiss

Rhode Island College

Follow this and additional works at: https://digitalcommons.ric.edu/etd

\section{Recommended Citation}

Weiss, Sara W., "Cross-Cultural Patterns of Disability in non-Western Societies" (1985). Master's Theses, Dissertations, Graduate Research and Major Papers Overview. 135.

https://digitalcommons.ric.edu/etd/135

This Thesis is brought to you for free and open access by the Master's Theses, Dissertations, Graduate Research and Major Papers at Digital Commons @ RIC. It has been accepted for inclusion in Master's Theses, Dissertations, Graduate Research and Major Papers Overview by an authorized administrator of Digital Commons @ RIC. For more information, please contact digitalcommons@ric.edu. 


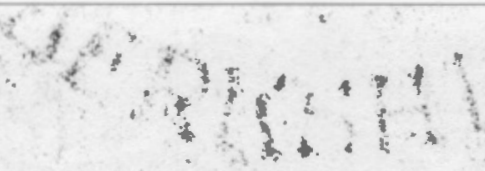

की - 3.

Anthropoiogy fGeography Department Galge Hall

Rhode Island College

Provildence, Rhode Island 02908

Cross-Cultural Patterns of Disability in non-Western Societies

Dr. R. Fidler

Sara W. Weiss

May 8, 1985 
Disability: An Investigation of Cross-Cultural Patterns in Non-Western Societies

With significant exceptions disabled persons and their disabilities have rarely been considered a topic of study by anthropologists. In fact, references to the disabled are difficult to locate in anthropological literature. Specific disabilities, such as deafness, have been researched by Kuschel: (1973); Shuman (1980); and Groce (1983). Nevertheless, anthropologists have not focused on the disabled as a separate entity in society. Goffman's (1963) work on stigma and the disabled remains an exception; important as the study is, it deals with only one aspect of disability. Until the disabled and their relationship with society is studied holistically by anthropologists and other social scientists, there will be a gap in the study of man and his culture.

Moreover, few if any theories about the disabled and disability have been developed, other than those dealing with specific handicaps. However, there are general theories such as man's adaptation to his environment and the dependence and interdependence of man as well as social systems that are applicable to the disabled. Those theories are too broad. Again, the formulation of specific theories on the subject of disability represents another challenge to anthropologists.

This investigation of cross-cultural patterns of the disabled in non-Western societies is an attempt to locate information in the anthropological record on the disabled and the problems caused by disabilities; to determine if the avail- 
able information forms a pattern when analyzed; and last, to see if any similarities exist between cultures. This study, then, is experimental and exploratory in nature, and as such, requires methodological adjustments.

Generally, when research is conducted, the researcher states the problem to be solved, asks him or herself questions about what he or she wishes to accomplish, reviews previous anthropological research material on the subject, and then forms a working hypothesis which may be modified as the study progresses. Terms and the population to be studied are defined; an accepted sampling procedure is decided upon; and a time frame with limits is set. The student formulates the methodology to be used. Then the research is conducted; the data is analyzed, and conclusions supporting or rejecting the hypothesis are reached.

Since this is an exploratory study, the research process has not proceeded as smoothly as the one described above. In the first place there are few anthropological studies to use as guides. There is little organized data on the subject of disability and the disabled, and the data tends to be fragmented. These difficulties were pointed out to the student by the faculty of the Anthropology Department at Rhode Island College when permission to conduct the study was requested. The Department's realistic approach and warning prevented this researcher from building up false hopes about uncovering great amounts of data that would be easy to analyze and to form into a report. 
The general goal of the research has been to study the disabled, their position, status, and role in non-Western societies. Ideally, the period covered would have been that time in the history of non-Western peoples when they had just been discovered by ethnologists and before those unique groups had been touched by outside influences. However, it was decided that the scarcity of information dictated that "no good data should be excluded arbitrarily." (Epple (1984; Fidler (1985). Whenever possible, the earliest ethnological study has been cited by the researcher.

As a starting point the student was asked to identify the disabled? Who are they? The following working definition has been used:

A handicapped person is one who has a physical, mental, or emotional impairment or disability which together with the existing environment and prevailing social conditions, substantially limits that person's life activities. (Rhode Island College Task Force Report of the Physically Handicapped, October 17, 1978).

In this study additional criteria are used. Disabilities may be hidden or obvious, long-term or permanent. A person may be born with a disability, or he or she may acuire a disability during his or her lifetime. Disabilities may be caused by genetic factors, disease, epidemics, accidents, war, old age, punishment or mutilation. Further, disabilities cover a wide variety of conditions: blindness, deafness, physical immobility, shortness of breath, extreme weakness, disfigurement such 
as harelip, webbed fingers, additional fingers and or toes. Albinos are considered disabled by some societies. Insanity, madness, mental illness, mental retardation, and epilepsy all fall under the inclusive term of disability. When Simmons studied the aged in society, he found that different societies viewed old age from different perspectives, and he stated that, "The simplest and safest rule to follow was to consider a person as 'old" whenever he was so regarded by his contemporaries" (1945:1). The same criteria has been followed in identifying the disabled in this research.

Since the aim of this research is to learn more about the position, the status and role of the disabled in society, the student prepared questions about the research problem that would lead to the formulation of a hypothesis. For example,

1. To what extent are persons with disabilities accepted and integrated into their societies? What determines acceptance or rejection? Is acceptance or rejection dependent. solely on the disabled individual and his or her aims and desires, or is acceptance or rejection based on the perceptions, feelings, attitudes, beliefs, and traditions of the society to which they belong?

2. Is acceptability or non-acceptability based on the availability of resources to the individual, the family, the community? That is, do opportunities for the disabled to be born, to grow up, to learn skills, depend on the resources that are available to him or to her? Further, do very poor 
societies who achieve bare subsistence for their group find the disabled more of a burden than societies with more resources at their disposal? Resources means availability of food, clothing, and shelter according to the needs of the society as well as opportunities for the individual with the disability to achieve his or her potential. Or, are there other reasons--social, environmental, or ideological--why societies and the able-bodied in them accept or reject the disabled? If so, what are the reasons?

One critical distinction between the disabled that affects acceptance and rejection is whether the disabled individual is born with a disability, or whether he or she acquires a disability sometime during his or her life. Some non-Western societies practice infanticide; this is done for various reasons. For this research it is important to learn whether the society practices infanticide to rid itself of infants with obvious disabilities according to the definition of the society, or whether infanticide is practiced on ablebodied infants as well. If a disabled infant is allowed to live, is he or she integrated into the society, and if so, how? Do minimal subsistence societies practice infanticide more often than societies with higher standards of living?

3. If an individual acquires a disability, how does her his or/society react? Does the group continue to accept the individual or do they reject him or her? This leads one to ask whether some disabilities are more acceptable to a particular group than other disabilities? If so, how is accept- 
ance or non-acceptance indicated by the group?

4. Other questions deal with the opportunities provided to the disabled by their society? Are opportunities based on social position or economic wealth according to the ways those terms are defined by the society? Or have societies, regardless of their means of subsistence and resources, found ways to assist dependent persons within their group, formally or informally?

Formulation of hypothesis: The questions listed above have led to the formulation of the hypothesis: There is a direct relationship between a society's well-being and the ability of the disabled to achieve self sufficiency. In this instance self-sufficiency means that the disabled, through individual, family, /group assistance is able to attain some control over his or her life, to participate in family and group activities to some extent, and to be of some use to his or her society. Self-sufficiency, then, is defined by the group as well as the family and the individual. The society's well-being means the subsistence level as well as the resources of the group. The inference is that the higher the subsistence level, the greater the resources, the more likely it would be for the disabled to achieve self-sufficiency.

Validity: The following measures of validity were chosen because infanticide, invalidicide, senilicide, marriage; special statuses and roles for the disabled; opportunities for individuals with disabilties, and isolation of the 
disabled provide some indication, and are a rough measure, of how persons with disabilties are accepted by their groups, and of the position of the disabled in their society.

Measures of validity:

1. Infanticide: Infanticide is the practice of killing an infant, usually new-born, but the procedure does not necessarily take place immediately. For this research it is important to determine whether infanticide is practiced on ablebodied infants as well as disabled infants or whether it is practiced on the able-bodied or disabled infants exclusively. This measure can be tested according to the resources of the society. If resources are scarce-food, clothing, and sheltef-as defined by a particular society, the likelihood that infanticide is practiced may be greater than for a society that has an abundance of resources according to their needs.

"X," the independent variable indicates the resources or subsistence level of a society; "Y," is the dependent variable; in this instance, it is infanticide. "X," causes "Y," that is, the subsistence level of the society determines whether a society practices infanticide or the degree that infanticide is practiced. Thus, a group who barely has enough to sustain it is more likely to practice infanticide or to practice infanticide more often than a group with more resources and provisions. 2. Invalidicide and senilicide are similar types of measures. Does the society abandon the sick, the disabled, and the aged infirm? Is there a custom within the group that 
permits either the individual or the group to kill persons who are no longer of use to their society? Again, do practices of senilicide and invalidicide occur more often in societies with the lowest levels of subsistence or do groups with more resources practice senilicide and invalidicide too, and to the same extent?

3. Marriage: Are the disabled integrated into societies to the extent that they marry and bear children? This question is related more closely to individuals who were born with disabilities, because persons who acquire disabilties may be married. In that case the critical question would be, did his or her spouse remain with the disabled individual, leave him or her, or obtain a divorce? Are individuals with specific disabilities such as leprosy, albinism, epilepsy, and others prevented from marrying more often than persons with disabilities such as blindness or deafness?

4. Special statuses and roles: Do minimal subsistence societies have special statuses or roles for the disabled among them? Or, are special statuses and roles provided only by societies with wealth and resources? Does the complexity of a society determine a wider variety of roles for the disabled?

5. Are opportunities for the disabled institutionalized in any way or ways? Do all societies provide care and sustenance to dependent persons, or again, is such care dependent on the resources of the society?

6. Isolation: Are all persons with disabilities iso- 
lated from the able-bodied in the society? Or, do persons with particular types of disabilities experience isolation? Methodology: Disabled persons in non-Western societies are the population under study. The Human Relations Area Files (HRAF) are being used to define and categorize the widespread population. The Files divide the world into eight "major world areas;" seven of the areas have been used in this study. Europe was excluded because the study is limited to non-Western societies. North American Indian tribes and Eskimos were included, because prior to Conquest, those societies had nonWestern cultures. "Culture Units," that is, individual groups within the Culture Areas are listed in this paper under the appropriate Culture area for purposes of convenience and clarity. HRAF

Code numbers for Culture Areas, and Culture Units have been used throughout, even for non-HRAF references; this was done for purposes of simplification and clarity.

Although the HRAF outline of World Cultures contains an tensive listing of world Culture Units, not all the Culture Units are to be found in the microfiche Files, because information for some Culture Units is not "available yet."

HRAF files were not the only source consulted; books, journals, newspapers, and other information have been used also. References within books, journals, HRAF files as well as biliographies in those sources led to information on the disabled and disability.

Sampling: Obtaining a random sample of the widespread 
heterogenous population presented a dilemma, but the HRAF Files provided a solution to the issue. The files recommend that a researcher utilize the "HRAF Probability Sample Files, a special selection of sixty Files." If the researcher is not able to complete the entire sample of sixty files, it is possible to "select randomly thirty or forty cultural Files from the total of sixty," while maintaining "roughly the same proportionate representation of the major world areas. . " (Legace, 1974:7). The HRAF sample guide was followed as closely as possible with the following exceptions:

1. It was impossible to cover the sixty cultures listed in the HRAF Probability Sample; a smaller sample was decided upon in accordance with the procedures outlined in "Nature and Use of the HRAF Files, A Research and Teaching Guide," noted above. Forty-seven cultures make up the sample. A copy of "Table 1. List of HRAF Files by Major World Areas" is included in the Appendix of this paper; the culture units covered by this research are underlined in red.

2. Information on the Dinka in the Sudan, the Barabaig in East Africa, the Besongye people of the Eastern Kasai Region, Republic of Zaire, the Woddabe Fulani of Bornu, Northern Nigeria, the Bantu of North Kavirondo, the Tharus of Uttar Predesh, India, the City of Peking, China, the City of Timbuctoo, Mali, Nubia, Maun, Botswana, and others are not available in the Files. Re-.. ferences, some of which are sparse, came from other sources. Additional information would have been welcome and useful, but the data was retained even when incomplete, because it either 
reenforced information about social institutions or was significant in itself.

Inclusion of the culture units listed in the preceding paragraph distorts the sample to some extent.

Obtaining the data: As noted previously, HRAF data is not always complete; some files are not available; other files have references for some categories and no references for others. In addition, HRAF data tends to be processed slowly and does not include the latest information from anthropological literature. Whenever possible, this researcher supplemented HRAF data with information from books, journal articles, bibliographical references, and other materials.

The HRAF files require practice to use efficiently; information on how to use the Files is scattered throughout the Adams Library at the College. Reference librarians are most helpful and cooperative in every way, but if the researcher does not know what he or she is looking for, it is impossible for the librarian to help a student. For example, a booklet, "Nature and Use of the HRAF, Research and Teaching Guide," is kept in the files of the reference librarian's office.and not with HRAF material in the Reference Section of the Library or on top of the microfiche cabinet in the Microfiche Room. This rein research

searcher was months along/before the informational booklet was discovered.

The HRAF files are categorized by subject; this.student used HRAF categories to locate as much information as possible in the Files, and as a way of locating information out- 
side the Files. The HRAF categories consulted are:

1. 101, Identification; 158 incidence of insanity; 164, Incidence of Organic Disease.

201, sign language; 220, Food Quest.

304, Mutilation.

429, Guardianship; 481, aids to locomotion.

681, Punishment; 682, Offenses against Life.

729, Care of Veterans; 732, Defectives, 734, Invalidism; 735, Begging; 736, Dependency; 737, Care of the Aged; 742, Medical Research; 750, Sickness; 752, Bodily Injuries; 753, Theory of Disease, 754, Sorcery, 755, Magical and Mental Therapy; 756, Physiotherapists, Shamans; 757, Medical Therapy; 758, Care of the Insane.

826. Interpretation of Physical Abnormalities; 828 , Interpretation of Mental Disorders; 845, Unusual and Difficult Births; and 847, Infanticide and Abortion.

References to specific disabilties such as blindness; deafness, crippling conditions, and others are located in the HRAF category, 732, Defectives.

As the research proceeded categories such as marriage, birth, rituals, and others were added.

In general, data on the disabled and the subject of disability is difficult to find. Many times the student found no obvious references to disability related topics in indexes, and tables of contents of books, but found, by chance, significant information about the disabled under other titles. For example, Chagnon (1977) has no references indicating disability in either the index or the table of contents of his book, Yanomamo, The Fierce People. However, there is an ex- 
cellent passage about a young man who lost a leg from snake bite. "The reference in the index is under "snakebite," which is now included as an important category for disability. A similar reference about "crippled, deformed, and demented girls," was found under "marriage" in The Barabaig: East Africa Cattle Herders, (Klima, 1970).

Order of Data: Data from references has been condensed. and placed on "Group" and "Individual" forms in the Appendix. The Group form provides general information about the disabled in each culture unit researched. The Individual form is an abbreviated case study of noteworthy individuals with disabilities. Group and individual information varies from a considerable amount to very small items.

The information on individuals is a measure, an indication, of how an individual with a disability is actually perceived and treated in a particular society. It also provides information about the ways that disabled persons with disabilities handle their particular problems and function in a community.

Completed group forms are to be found in the Appendix under the major culture areas: Asia, Africa, Middle East, North America, Oceania, Russia, and South America. Identification of culture units may be found in the upper right hand corner of the form. For analytical purposes, culture units are classified according to subsistence levels: hunters and gatherers, horticulturalists, pastoralists, intensive agriculturalists, and industrial societies. There may be some 
question about the classification of groups by modes of subsistence; some societies are not easily categorized.

Case studies, some are not deserving of the title, are the last category in the Appendix. They are filed according to the HRAF culture unit code, noted in the upper right hand corner of the form.

Analysis of Data: Tnfanticide, invalidicide and senilicide, marriage, attention to the disabled--positive and negative--social institutions, statuses and roles, are the major categories of the data analyzed.

Infanticide: The nuclear family, especially the mother, the extended family, and/or the community in non-Western societies decide whether a disabled, deformed, disfigured, or otherwise unusual infant should live. This analysis attempted to differentiate between infants who were unwanted because of pressures on the mother or the group. For example: Hunting and gathering societies carry their worldly goods with them. Parents, especially, the mother, carry their children. In addition, the mother generally nurses her infant from three to five years. If an infant is born, with or without a disability, while the mother is still nursing her previous child, the newborn infant is put to death; the mother can neither nurse nor carry two infants at the same time. "Unwanted infants" come under this category. (Table 3, Appendix) The second category, "Selective, other than disabled" includes infants who are killed because they are female, male, illegitimate, 
either one, or both, twins, or albinos. The third category "disabled," is provided for the killing of infants because they are disabled, deformed, or otherwise impaired according to the definitions of the community.

The data indicates that in the forty-seven societies researched, thirteen groups practiced infanticide on unwanted infants; ten groups practiced infanticide because of sex, of the infant, illegitimacy, twins, or other reasons. Thirteen groups killed disabled infants. Some groups practiced infanticide for more than one reason. There was no information regarding the practice or non-practice of infanticide in the remaining societies.

In a few instances there is a difference of opinion among ethnologists on whether infanticide was or was not practiced. In that case the researcher listed the society as having practiced infanticide. Groups who practiced infanticide in the past may not be doing so now, but thoșe groups were counted as practicing infanticide because the earlier data gives a truer picture of the society prior to acculturation.

Limited as it is, the data indicates that infanticide was practiced more often among hunters and gatherers and horticulturalists than among intensive agriculturalists and industrial societies. However, fewer communities in the last two categories were researched which is a significant defect in the sample. It is also possible that the student, after prolonged deliberation, placed a culture unit in the incorrect subsistence category. 
Interesting facts about the practice of infanticide on disabled infants have been noted. The Bantu of North Kavirondo in the Nyanza Province of Kenya kill deformed infants, not because of pressures on the mother or group, but because it is believed that deformed infants are the result of an incestuous. relationship on the part of the mother. In such an event the mother goes through a purification ceremony and is regarded with some disfavor by her community. (Wagner, 1956:297) The Dogon believe that "malformed children" are caused "by the union, perhaps involuntary on the part of the woman, with a spirit of the bush. (Paulme, 1940:410) The Besonyge are the only society encountered who do not kill disabled infants immediately; the death is postponed until the matter is brought before the council who generally suggests that time may cure the problem. Sometimes the children are advanced in age before being put to death. (Merriam, 1974:208)

It is significant that the Siriono of Bolivia, hunters and gatherers under harsh environmental conditions, do not practice infanticide, and abortion appears to be equally unknown. (Holmberg, 1950: HRAF: 847)

Senilicide and invalidicide: The senilicide category is divided into the "infirm," and "dependent." (Table 3, Appendix). The two categories were combined under the term "senilicide" for purposes of convenience, but "dependent" persons could be any age. Exposure to Christianity and to Western thoughtalso has affected groups who formerly practiced 
senilicide, but do not do so now, are categorized as practicing senilicide for the same reason as given above. There are conflicts within societies concerning the practice of senilicide. The Caingang, a hunting and gathering society in Brazil and Argentina, have been known to abandon the aged infirm when they moved their camp; (Henry, 1941:116) however, the author notes that the Caingang "carried the aged infirm on their backs when they were unable to walk or to walk fast enough."

In their book on The Native Tribes of Aboriginal Australia, Spencer and Gillen (1968:51) state that, "There is no such thing as doing away with aged or infirm people, " but Blainey (1976: 98, 101-102) disagrees with the British authors when he writes, "that infanticide, invalidicide and senilicide occurred, and he attributes the killing of infants, dependents, and the aged to other than environmental and personal reasons. He claims, "Heartless pressures were also at work."

Table 3, Senilicide, does show that twenty-three societies practiced some form of senilicide. The sole agricultural community investigated, who practiced senilicide, are the Dinka of Sudan. The author states, that the reasons for doing so were "in part to avoid the degrading consequences of senility in old age. - Dinka chiefs were not allowed to die naturally, but were buried alive when too old to function or when they thought themselves near death." (Deng, 1971:121) There is a close relationship between the aged and disability, because a significant percentage of the aged acquire disabilities. 
Marriage: Data on persons with disabilities who either allowed or not allowed to marry is also fragmentary: Thirty societies of the forty-seven researched failed to have any information about the disabled and marriage in their communities. Marriage is a significant measure of how completely the disabled were integrated into non-Western communities, because, generally, marriage in such societies is important. Examples of two deaf men in widely separated localities, provide some insight to the situation. Lorenzo, of Nohya Village, Central Yucatan, and Kangobai, Rennell Island, British Solomons, have much in common. Both men were the first persons born in their respective communities who were totally deaf and mute. Since Lorenzo's birth in 1933, eleven other deaf persons have been born in his village, but according to the oral history of Rennell Island, Kangobai, was the only deaf person in twenty-four generations. Both men taught themselves sign language, although some persons say that Lorenzo's sister taught him. There was no one on Rennell Island who knew sign language; there are no words for "deaf-mute" or "sign language" in the Rennelese language. (Kuschel, 1973:4) Lorenzo is described as being "Alert and intelligent, . . a tireless worker whose labors show extreme attention to detail and more than a hint of perfectionism. (Shuman, 1980: 361) Lorenzo is a talented artist; weaver, basket and hammock maker. The community is proud of his artistic talents, and he is highly respected. 
The same is true of Kangobai. He is an excellent worker; males in his society are expected to be good gardners and fisherman, and he does both well. So well, that he has an abundance of fish and produce which he shares with his family and friends. Kangobai, like Lorenzo, belongs to a "high status" family which the author cites as one reason for Kangobai's successful integration into the society; another reason is "his own creativity and imagination." Citizens of both towns have learned sign language in order to communicate with the two men. Both societies stress the importance of marriage, yet both men remain single. In Nohya, the institution of godparentship, compadrazgo, is practiced, but Lorenzo has never been asked to fill this important role. Similarly, Kangobai's unusual abilities are not recognized by all persons in his community. (Kuschel: 6-7). The Wodaabe Fulani of Bornu do not allow the sick, disabled, and especially the insane to marry, become betrothed, or own cattle; in addition, there is a social stigma attached to disability. (Stenning, 1959:126)

Other persons with disabilities do marry; Kawina Liwema is one. He lives in the village of Chokolatwe in Zaire, and works under the tutelage of Sanjolombo, a master woodcarver. Liwema is married and has two children. (Crowley, 1973:221-247) Embree reports that thereiwas a deaf and dumb woman in Suye Mura who had been married two times. "(she) runs her household remarkably well. Attends all buraka functions, and talks 
to her friends by making graphic signs. She even dances at the drinking parties." (1939:129) Obviously, she is integrated into her society and self-sufficient.

Special Attention to the Disabled (Positive and Negative): Under the "Positive" category, support systems such as family, community, institutional, and other types of systems have been included. Nearly all groups or communities, depending on their social structure, have ways, formal and informal, to assist and care for dependent persons.

!Kung Bushmen have informal support systems; the family is responsible for the care of dependents. LamefGao contracted a bone disease when he was a child; one leg was withered, and he walked with a cane. After LamefGao became crippled, N/aoka, his mother, carried him on her back for years. (Marshall, 1976: 288). However, Lame $\neq G a$ was able to stalk and kill a buck, and thus became a man according to Bushman practice; he also married.

The Blind Guild, a formal type of support system, developed in Peking, China. The blind have their own Guild which serves them professionally and socially. The members belong. to entertaining professions and are musicians, and storytellers. The Guild has strict rules for its members and maintains high professional standards. Members are required to serve apprenticeships and are subject to fines (in earlier times to beatings) if they did not comply with Guild regulations. At the Guild meetings blind men form queues, holding on to one another's pigtail, thus finding their way around the Guild hall. (Burgess, 1966:103,105, 131, 137, 160) 
The Migiurtini of Somali and the Kanuri of Bornu assume responsibility for the behavior of their tribesmen who cause disability to another; these two groups pay the injured person 50-she camels if one of their members has "blinded an eye" or "cut off a foot or hand." (Cerulli, 1964:94)(Cohen, 1967: HRAF: 682)

Islam provides a support system too; Moslems are expected to share their wealth with the less fortunate--poor, sick, and disabled-by giving alms for their support. This system prevails throughout the Middle East; although it is probably practiced more strictly in some places than in others.

Negative Attention to the Disabled: Ridicule, isolation, and discrimination in its many forms is included in this category. Priesthood, for instance, is denied "lepers, madmen and epileptics, and the deformed on the Island of Bali. (Covarrubias, 1938:303) In addition, "Tabooed for sexual relations are albinos, idiots, lepers, and in general the sick and deformed" on the Island of Truk. (144) On Truk Island, Gladwin and Sarason (1953: 153-154) describe a situation where a "crippled boy was taunted and teased and ridiculed by children." Marshall reported that the IKung Bushmen ridicule crippled persons. "lKung children mimic peculiarities of posture and movement, " and they, both children and adults, laugh when a crippled person falls and fail to help him up. (1976:288) In Phenix Village, South China, Kulp (1925:54) says that dependents or persons with disabilities are set apart from the larger community. "In addition to the dependence 
they suffer feelings of inferiority that develop in them abnormal psychic traits. - Especially true of marginal cases such as cripples, people with harelip, and the otherwise physically abnormal. Landor (1893:vii) noted that the mentally disabled were not treated well by the Ainu, "the unfortunate creature, thus afflicted seems to lose not only the respect, but also the pity, as well as care of all others and is treated by them as a worthless animal."

Special Statuses and Roles: Over time societies have developed special roles for the disabled; some serve as sorcerers for the Ojibwa, a very difficult role (Jenness, 1959:84) The Iban of Sarawak have a vocation for persons with disabilities, called Manang. In a complex manner of reasoning, the blind are associated with darkness, thus the spirit world and are thus eligible, along with others, to prepare them selves for the vocation. (Jensen, 1974:144-145) Geidam, an urban center for the Kanuri of Bormu, has a special section of the town reserved for blind persons who make rope; they elect their own officials. (Rosman, 1962:129) Islam has institutionalized the role of beggar for persons with disabilities, and in Rowanduz, a Kurdish town, harmless eccentrics may become Darwishes, a role that provides them with a "channelled experience for personal peculiarities that might otherwise prove dangerous. (Masters, 1953:321) The town of Suye Mura, Japan, has a long tradition of blind priests, called Kitoshi, and in Nubia, elderly blind Holy men teach the Koran to young students. (Kennedy, 1977: 26); (Embree, 1939:190) 
Other valuable information about the disabled has surfaced. In addition, to social institutions and roles, there are myths and rituals related to the disabled and disability. The Hausa, as well as other non-Western societies have a welldocumented folk-lore tradition which gives considerable insight, although it requires much further study, to the way a society observes the disabled. Tremearne $(1913: 60)$ cites games and riddles, and myths about persons with various types of disabilities; the author describes a Bori dance, no longer allowed, in which persons with disabilities are portrayed, 2 deaf-mute called Bebe, was one. The Bori dance was originally intended to help the insane, "the idea being that those who were really mad would be thereby less likely to commit acts of violence. . ." (146).

Lambrecht (1932, 1941-1955:95) describes the "U-Lap rites" an exorcism ritual to cure persons afflicted with sudden blindness. The Arunta know the whereabouts of a "blind tree," where a hunter may go if he wishes blindness on an enemy, and in Suye Mura, persons who are deaf or becoming deaf, collect a certain type of stone and add it to piles of wayside stones (stones are deaf) and present them to "Jizo."(Spencer and Baldwin, 1968:552553) and (Embree, 1939:246-247)

At least nine of the groups investigated believe that disability is caused by witchcraft or evil spirits. People such as the Hopi Indians attribute crippling conditions to an illicit love affair, and albinism to to the theft of a sacred doll. (Titiev, 1971, 1972: 88, 159) 
There appear to be pockets of similar disabilities in various parts of the world. Both the Aymara and the Siriono Indians in South America have a high incidence of clubfootedness. Holmberg estimated that, "This trait appears in 15 percent of the (Siriono) population." (1950:9). Chabot (1950: 160) reported that he found a large number of unmarried people at Makassar, and the author attributes the situation to an equally high number of deaf mutes there. Albinism is prevalent among the Cuna Indians of/San Blas Islands. It can be argued that albinism is not a disability, but there are degrees of disability, and the people of San Blas assign albinos a special status because there is a myth that albinos occupy a special place in heaven, and people want to keep in their good graces. Albinos are not expected to work as hard as other persons, and the men, particularly, are restricted from marrying. However, albino men serve on councils and are highly respected. (Marshall, 1950: HRAF categories 116,143,826).

Analysis of Individuals with Disabilities: These accounts are to be found in the last section of the Appendix.

Ogotemmele, a respected man and hunter in Dogon, lost one eye when he had smallpox as a child; he lost the other eye when his gun exploded in his face. Ogotemmele used his time after he became blind to study the complexities of the Dogon religion and to become an expert on the subject. He realized that his religion should be shared with the world, and made arrangements to meet with the French anthropologist, Marcel Griaule, to explain Dogon precepts to the Frenchman and his companions. 
The first conversation took place in October, 1946; the sessions continued for about a month. Griaule wrote about his "Conversations" with Ogotemmele in 1965. Ogotemmele probably was not self-sufficient in that he cooked his own meals, cared for his clothing, or performed daily chores. His high status ensured that others performed those tasks for him. His contributions were ideological; he served his people as a spiritual leader and guide. He became famous in Dogon and throughout the World. (Griaule, 1965:14-15)

!Kham, a Bushman of the Nyae Nyae area, was crippled. he walked with "two forked sticks." He was married and the father of four children. However, he and his wife, $\mathrm{Be}$, occupied a somewhat marginal position among the Bushmen because he was crippled and could not hunt, and because he and $\mathrm{Be}$, had few family to assist them. However, !Kham and Be made themselves useful to other Bushmen by carrying messages, gifts, news and gossuip from one band to another. In exchange, the groups he and his family visited, provided him and his family with meat. Be gathered for them. However, he and Be were constantly on the move so as not to stay with one group too long. This is an example of the way reciprocity works in a hunting and gathering society. (Marshall, 1976: 187)

Hajji Mustafa, a citizen of the Kurd town of Rowanduz, is portrayed as a slightly eccentric, but harmless individual. He was considered the "worst barber in town;" however, he was a "colorful town figure" and "beloved by the children." Haggi Mustafa became a Darwish, which gave him a social status and 
an outlet for his emotional needs. In line with Islamic precepts, Hajji and his family were, for all practical purposes, cared for by the house of Shakir Effendi who gave "gifts of food and money." However, Darwishes "charmed. snakes" and swallowed large pebbles to entertain and amuse the public. (Masters, 1935: 321, 329)

As pointed out earlier, persons may be born with disabilities or may acquire them. Two men in Azande, in different times, were accused of adultery and mutilated by having their hands and genitals cut off. One of them, Bitarangba, was photographed and described by Evans-Pritchard. The mutilated man was cared for by his blood brothers.' (Evans-Pritchard, 1933: HRAF:736) The Ainu punished thieves by cutting off both or one hand. The heel tendons were cut of murderers; the operation left the victim completely crippled. (Batchelor, 1927:38-39)

Conclusions: The hypothesis that, "There is a direct relationship between a society's well-being and the ability of the disabled to achieve self-sufficiency has not been proven or disproven. As noted, the data are not complete; some are not comparable. There are some indications that hunting and gathering societies and horticultural societies practiced infanticide more than pastoral, agricultural, or industrial societies. From the amount of data available, it appears that hunters and gatherers and horticulturalists practiced senilicide and invalidicide more frequently than pastoralists, agriculturalists, and industrial societies. It will be interesting to see if these slight trends hold up when a larger and more complete sample is obtained. 
With the limitations of the data in mind, marriage of the disabled appears to occur more often, especially among hunters and gatherers, horticulturalists and pastoralists, than one might expect.

The last category, "Special Attention to the Disabled" indicates that there are a great many systems, formal and informal, that are used by non-Western societies to assist dependent persons in their communities. As noted, some attention that persons with-disabilities receive is of a negative nature.

One goal of this research. was to determine the extent of information about the disabled in the anthropological record. Although the data is difficult to locate, information is available, and with more practice the student should be able to obtain material more efficiently. Another goal was to analyze the data in the hope of discerning trends or patterns. This aim has not been realized, but a beginning has been made. After further research it may be that a more representative sample may be obtained and compared with this first data. The last goal, to see if similarities between cultures exist, appears to be confirmed to some extent.

This student considers this project as a basis for the research that is to follow. If a graduate study were to be conducted, the procedure outlined previously would be used with some modification.

The HRAF files would be used but would be supplemented 
with other research material. The most effective way to find every possible reference on disability would be to read entire books rather than trying to locate information in the HRAF files, indexes, and tables of contents. Bibliographies have proved excellent sources for references; the articles on Lorenzo, the Mayan deaf man, and Kangobai of the Rennell Islands were found in this way. Ogotemmele was found by chance. Studying disability may be like studying the aged; the researcher may have to use every available scrap of information, regardless of what it does to the sample, because the material is fragmented.

It is important that further study of the disabled should focus on them in the entire society. In order to achieve this goal, more will have to be learned about marriage, institutions, special statuses and roles, punishment, modes of subsistence--in short all about a culture-so that the disabled may be better understood in a social context.

Abstract Proposal: Despite the difficulties inherent in undertaking a study of the disabled and the subject of disability in non-Western societies, such research is essential in order to obtain a fuller understand ${ }^{\text {of }} f$ the status and role of the disabled in society. As noted, little work has been done in the field of Anthropology. This undertaking would be a general, study, rather than an investigation of specific disabilities; however, this research would incorporate material from studies of particular disabilities 
In addition, the study would focus on cross cultural patterns of disability among non-Western peoples, preferably prior to Western acculturation.

The working hypothesis would be that there is a direct relationship between the society's well-being and the ability of the disabled to achieve a satisfactory status in a. particular society. The research would be conducted accordStandms. ing to prescribed;utilizing as mich of this work as possible. HRAF recommendations would be followed, but may not be the same as those followed for this paper. The student would like to investigate as many societies as possible, and it may be that a different sampling procedure will have to be worked out. Statistical analysis of the data would be used. By using the methods mentioned above, it is hoped that generalizations may be made about the disabled, that patterns will become apparent, and that similarities between societies will become more pronounced. Such a study would provide useful information about the disabled and hopefully give insight to the ways that society perceives and interacts with the disabled. 
Footnotes

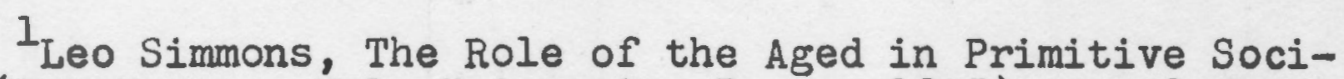
ety, (New Haven: Yale University Press, 1945), p. 1.

2 A Research and Teaching Guide,"

Legace, "Nature and Use of the HRAF Files,

${ }^{3}$ Napoleon A. Chagnon, Yanomamo, The Fierce People, (New York: Holt, Rinehart and Winston, 1977), p. 20.

${ }^{4}$ George J. Klima, The Barabaig: East Africa CattleHerders, (New York: Holt, Rinehart and Winston, 1970), p. 64.

${ }^{5}$ Gunter Wagner, The Bantu of North Kavirondo, (Iondon: Oxford University Press, 1949-1956), p. 297.

${ }^{6}$ Denise Paulme, [Social Organization of the Dogon (French Sudan)], (Paris: E'ditions Domat-Montchrestien, F. Loviton et cie., 1940), p. 410.

7 Alan P. Merriam, An African World. The Besongye Village of Lupupa Ngye, (Bloomington: Indiana University Press, 1974), p. 208 .

${ }^{8}$ Alan $R$. Holmberg, Nomads of the Long Bow, The Siriono of Eastern Bolivia, (Garden City, New York: The Natural History Press, 1950), HRAF category 847.

Jules Henry. Jungle People: A Kaingang Tribe of the Highlands of Brazil, (New York: J. J. Augustin, [C. 1941]), p. 116.

10 Baldwin Spencer and F. J. Gillen, The Native Tribes of Central Australia, (New York: Dover Publications, 1968), p. 51.

$11_{\text {Geoffrey Blainey, Triumph of the Nomads, A History of }}$ Aboriginal Australia, (New York: The Overbrook Press, 1976), pp. $98,101-102$.

12 Francis M. Deng, Tradition and Modermization, A Challenge for Law among the Dinka of the Sudan, (New Haven: Yale University Press, 1971), p. 121 . 
${ }^{13}$ Rolf Kuschel, The Silent Inventor, p. 4.

$14 \mathrm{Malcolm} \mathrm{K}$. Shuman, Culture and Deafness, p. 361.

${ }^{15}$ Rolf Kuschel, The Silent Inventor, pp. 6-7.

16. Derrick Stenning, Savannah Nomads, A Study of the Wodaabe Fulani of Western Province Northerm Region, Nigeria, . (London: Oxford University Press, 1959), p. 126.

${ }^{17}$ Daniel J. Crowley, "Aesthetic Value and Professionalism in African Art, Three Cases from the Katanga Chokwe," in "The Traditional Artist in African Societies, ed Warren d'Azevedo (Bloomington; Indiana University Press, 1978), pp. 221-247.

${ }^{18}$ John F. Embree, A Japanese Village Suye Mura, (Chicago: The University of Chicago Press, 1939), p. 129.

${ }^{19}$ Lorna Marshall, The !Kung of Nyae Nyae, (Cambridge, Mass: Harvard University Press, 197I), p. 288.

20 John S. Burgess, The Guilds of Peking, (Taipei: Ch'engWen Publishing Company, 1966), pp. 103, 131, 137, 105, 160.

$21_{\text {Enrico Cerulli, ["The Consuetudinary Law of Northern }}$ Somalia,"]: In Somalia ed. Scritti Vari Edita, (Roma: A Cura dell' Amministrazione Fiduciari Italiana della Somalia, 1959), 94.

22 Ronald Cohen, The Kanuri of Bormu, (New York: Holt, Rinehart and Winston, 1967), HRAF: 682.

${ }^{23}$ Miguel Covarrubias, Island of Bali, With an Album of Photographs by Rosa Covarrubias, (New York: Knopf, 1938), p. 303.

24Thomas Gladwin and Seymour B. Sarason, Truk: Man in Paradise, (New York: Wennergren Foundation for AnthropologicaI REsearch, 1953) pp. 153-154.

${ }^{25}$ Lorna Marshall, The !Kung, p. 288.

${ }^{26}$ Daniel H. Kulp, II., Country Life in South China, (New York: Teachers College, Columbia University, Bureau of Publications, 1925) p. 54 .

27 Arnold H. Landor, Alone with the Hairy Ainu, Or, 3800 Miles on a Pack Saddle in Yezo and a Cruise to the Kurile Islands, (London: lứray, 1893), p. vii. 
27Diamond Jenness, The Ojibwa, Indians of Parry Island, Their Social and Religious Life, Tottawa: National Museum of Canada.

28 Erik Jensen, The Iban and Their Religion, Oxford Monographs on Social Anthropology, $(1974), \mathrm{pp}$. 144-145.

29 Abraham Rosman, "Social Structure and Acculturation among the Kanuri of Northern Nigeria," (Ph.D. dissertation, Yale University, 1967) p. 129.

39illiam M. Masters, "Rowanduz: A Kurdish Administrative Center," (Ph.D. dissertation, University of Michigan, 1953), p. 321.

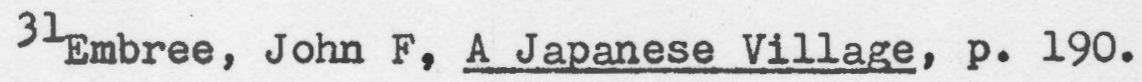

32 John G. Kennedy, Struggle in a Nuclear Community, An Individual in Society and History, (Palo Alto, California: Mayfield Publishing Co., 1977), p. 26.

33 A. J. N. Tremearne, Hausa Superstitions and Customs, An Introduction to the Folklore and the Folk, (London: Frank Cass and Company, Ltd., 1970), p. 60.

34 Ibid., p. 146 .

35 Frances Lambrecht, "The Mayawyaw Ritual VI, IIlness and its Ritual, Journal of East Asiatic Studies, 4 (1955): 1-155.

36 Baldwin Spencer and F. J. Gillin, The Native Tribes of Central Australia, (New York: Dover Publications, 1968), pp. 552-553.

37 John F. Embree, A Japanese Villiage, pp. 246-247.

38 Mischa Titiev, Old Oraibi: A Study of the Hopi Indians of the Third Mesa, (New York: Kraus Reprint, 1971), pp. 88, 159.

${ }^{39}$ Alan R. Holmberg, Nomads of the Long Bow, p. 9.

40 Hendrik Chabot, [Kinship, Status, and Sex in South Celebes.] [Groeningen, J. B. Wolters, 1950], p. 160 .

4lDonald S. Marshall, "Cuna Folk: A Conceptual Scheme Involving the Dynamic Factors of Culture, as Applied to the Cuna Indians of Darien, (Ph.d dissertation, Harvard University, 1950), pp. 116, $143,826$. 
42 Marcel Griaule, Conversations with Ogotemmeli, An Introduction to Dogon Religious Ideas, (London: Intermational African Institute. Oxford University Press, 1965),
pp. 14-15.

${ }^{43}$ Lorna Marshall, The !Kung, p. 187.

44 William M. Masters, "Rowanduz," pp. 321, 329.

45Edward E. Pritchard, "Zande Blood-brotherhood," Africa, 6 (1933): 369-401.

$46 \mathrm{John}$ Batchelor, Ainu Life and Lore: Echoes of a Departing Race, (Tokyo, Kyobunkwan [1927?], pp. 38-39. 


\section{Bibliography}

Alland, Alexander, Jr. Adaptation in Cultural Evolutions: An Approach to Medical Anthropology- New York: Columbia University Press, 1970.

Ames, David W. "A Sociocultural View of Hausa Musical Activity." In. The Traditional Artist in African Societies. Bloomington, Indiana: Indiana University Press, 1973.

Anderson, R. G. Some Tribal Customs in Their Relation to Medicine and Morals of the Nyam-Nyam and Gour People Inhabiting the Eastern Bahr-EI-Ghazal. Welcome Tropical Research Laboratories at the Gordon Memorial College, Khartoum, Report, 4B(1911).

Barton, Roy F. Ifugao Law. Berkeley University of California Press, 1919.

Batchelor, John. Ainu Life and Lore: Echoes of a Departing Race. Tokyo: Kyobunkwan [19277].

Becker, Howerd, ed. Societies Around the World. New York: The Dryden Press, Inc., 1956. A New Shorter Edition.

Bicchieri, M. G., ed. Hunters and Gatherers Today. New York: Holt, Rinehart and Winston, Inc., 1972.

Blainey, Geoffrey. Triumph of the Nomads. A History of Aborignal Australia. New York: The Overbrook Press, 1976.

Bolender, Gustaf. [The Indians of the Tropical Snow-Capped Mountains: Investigations in Northernmost South America.] Stuttgart: Strecker and Schroder, 1925.

Bollig, Laurentius. [The Inhabitants of the Truk Islands. Religion, Life and a Short Grammar of Micronesian People. I Munster in Westphalia, Ascheradorffsche Verglags-buchhandlung, 1927,8 .

Bogoraz-tan, Vladimir G. The Chukchee. By Waldemar Bogoras. Leiden: J. Brill; New York: G. E. Steehert, 1904-1909.

Brandt, Richard B. Hopi Ethics. A Theoretical Analysis. Chicago: The University of Chicago Press, 1954.

Brettes, Joseph de. [The Arthuaco-Cagaba Indians: Replies to the Sociological and Ethnographic Questionnaire of the Societe d' Antropologie.] Societe d' Anthropologie de Paris, Bulletins et Memoires, Serie 5, 4(1903): 318-357. 
Burgess, John S. The Guilds of Peking. Taipei: Ch'eng-Wens Publishing Company, 1966.

Cerulli, Enrico. ["The Consuetudinary Law of Northern Somalia." In Somalia, scritti Vari Editi ed.] Inediti. Vol 2. Roma, A Cura dell' Amministrazione Fiduciarie Italiana della Somalia, 19.59: 1-74, 382-384.

- ["The Somali Tribe," In Somalia, Scritti Vari Editii ed. Inediti. Vol. 3. Roma, Mínistero Degli Affari Esteri, 1964: $45-113,225-226,229$.

Chabot, Hendrik, T. [Kinship, Status, and Sex in South Celebes.] [Groeningen, J. B. Woltera, 1950.]

Chagnon, Napoleon A. Yanomamo, The Fierce People. New York: Holt, Rinehart and Winston, 1977.

Cipriani, Lidio. The Andaman Islanders. Translated and Edited by $D$. Taylor Cox assisted by Linda Cole. New York: Frederick A. Praeger, 1966.

Cohen, Ronald. The Kanuri of Bornu. New York: Holt, Rinehart and Winston, 1967.

Covarrubias, Miguel. Island of Bali. With an Album of Photographs by Rosa Covarrubia. New York: Knopf, 1938.

Crowley, David J. "Aesthetic Value and Professionalism in African Art. Three Cases from the Katanga Chokwe." In The Traditional Artist in African Societies. Edited by d'Azevedo, Warren L. Bloomington, Indiana: Bloomington Indiana Press, 1973.

De Smidt, Leon S. Among the San Blas Indians of Panama, Giving a Description of Their Manners, Customs, and Beliers. Troy, New York: [1948].

Deng, Francis M. Tradition and Modernization. A Challenge for Law among the Dinka of the Sudan. New Haven: Yale University Press, 1971.

- The Dinka of Sudan. New York: Holt, Rinehart and Winston, 1972 .

Du Bois, Cora. The People of Alor, A Social-Fsychological Study of an East Indian Island. Cambridge, Massassachusetts: Harvard University Press, 1960.

Eggan; Frederick R. Social Organization of the Western

Pueblo. Chicago: University of Chicago Press, 1950. 
Embree, John F. A Japanese Village, Suye Mura. Chicago: The University of Chicago Press, 1939.

Etter, Carl. Ainu Folklore, Traditions, and Customs of the Vanishing Aborigines of Japan. Chicago: Wilcox and Follett Co., 1949.

Evans-Pritchard, Edward E. "Zande Blood-brotherhood." In Africa, 6(1933): 369-401.

- "Witchcraft (Mangu) among the A-zande." Sudan Notes and Records, 12(1929): 163-249.

- "Heredity and Gestation, as the Azande See Them." Sociologues, 3(1932): 400-414.

- Man and Woman among the Azande. Edited' by E. E. Pritchard. New York: The Free Press, 1974.

Evans, Meryle. "In Botswana, Recipes from Rochester." The New York Times, 15 August 1984.

Fenton, William N. The Iroquois Eagle Dance, An Offshoot of the Calumet Dance. Washington, D. C.: The Smithsonian Institution, 1953.

- "Contacts between Iroquois Herbalism and Colonial Medicine." The Smithsonian Institution; Annual Report of the Board of Regents, 96(1940-1941): 503-526.

Firth, Raymond. We, The Tikopia. Kinship in Primitive Polynesia. Boston: Beacon Press, 1957.

- Primitive Primitive Polynesian Economy. New York: W. W. Norton and Company, Inc., 1965

Gibbs, James L. Jr., Peoples of Africa. New York: Holt, Rinehart and Winston, Inc., 1965.

Gladwin, Thomas, Truk: Man in Paradise. By Thomas Gladwin and Seymour B. Sarason. NeW York: Wennegren Foundation for Anthropological Research, 1953. [c. 1954]

Gomes, Edwin H. Seventeen Years among the Sea Dyaks of Borneo: A Record of Intimate Associations with the Natives of the Bornean Jungles. With an Introduction by the Reverend John Perham. London: Seeley, 1911.

Goodenough, Ward H. Property, Kin, and Community on Truk. Foreward by G. P. Murdock. New Haven: Yale University Press, 1951. 
Greenberg, Joseph H. The Influence of Islam on a Sudenese Religion. New York, J. J. Augustin [1947].

Griaule, Marcel. Conversations with Ogotemmeli. An Introduction to Dogon Religious Ideas. London: International African Institute. Oxford University Press, 1965.

Hansen, Benny H. The Kurdish Woman's Life: Field Research in a Muslim Society. Iraq: Kobenhavu, National Mus 1961.

Harris, Reginald F. "The San Blas Indians." The American Journal of Physical Anthropology, 9(1926): 17-63.

Hassan, Alhaji. A Chronicle of Abuja. Translated and Arranged from the Hausa of Malam Hassan and Malam Shuaibu [by Frank Heath.] Ibadan: Ibadan University Press, 1952.

Henry, Jules. Jungle People: A Kaingang Tribe of the Highlands of Brazil. [New York] J. J. Augustin [C. 194I].

Hickerson, Harold. The Southwestern Chippewa: An Ethnohistorical Study. Menasha, American Anthropological Association, 1962.

Hilger, Inez M. Chippewa Child Life and Its Cultural Background. Washington, D. C.: Government Printing Ofilce, 1951.

Hooper, William H. Ten Months among the Tents of the Tuski, with Incidents of an Arctic Boat Expedition in Search of Sir John Franklin, as far as the Mackenzie River and Cape Bathurst. London: John Murray, 1853.

Howell, William. [A Collection of Articles on the Sea Dyak.] Sarawak Gazette, (1908-1910): 38-40.

Jenness, Diamond. The Ojibwa Indians of Parry Island, Their Social and Religious Life. Ottawa National Museum of Canada, 1935.

- The People of the Twilight. Chicago: Chicago University Press, 1959.

Jensen, Erik. The Iban and Their Religion. Oxford Monographs on Social Anthropology, 1974, pp. 144-145.

Kennedy, John G. Struggle in a Nuclear Community. An Individual in Society and History. Palo Alto, California: Mayflower Publishing Co., 1977.

Klima, George J. The Barabaig: East Africa Cattle-Herders. New York: Holt, Rinehart and Winston, 1970. 
Kohl, J. G. Kitchi-Gami. London: Chapman and Hill, 1860.

Kramer, Augustus. Truk. [Truk] Hamburg: Friederichsen, de de Gruyter, 1932 .

Kulp, Daniel, H. II. Country Life in South China. Teachers College, Columbia University, Bureau of Publications, 1925.

Kuschel, Rolf. "The Silent Inventor: The Creation of a Deaf Sign Langrage by the Only Deaf Mute on a Polynesian Island." In Sign Language Studies, V. 3. (October 1973): 1-27.

La Barre, Weston. "The Aymara Indians of the Lake Titicaca Plateau, Bolivia." In Memoirs. New York: Published by American Anthropological Association, Vol. 50, (January 1948): 3-24l.

Lambrecht, Frances. The Mayawyaw Ritual, Parts 1-5. Washington, D. C. Catholic Anthropological Conference, 1932-194l.

- "The Mayawyaw Ritual, VI. Illness and Its Ritual." Journal of E. Asiatic Studies, 4, No. 4(1955): 1-155.

Landes, Ruth. Ojibwa Sociology. New York: Columbia University Press, 1937.

The Ojibwa Woman. New York: Columbia University Press, 1938.

Landor, Amold H. Alone with the Hairy Ainu, Or, 3800 Miles on a Pack Saddle in Yezo and A Cruise to the Kurile Islands. London: Murray, 1893.

Landy, David, ed. Culture, Disease, and Healing. Studies in Medical Anthropology. New York: Macmillan Publishing Company, Inc., 1977.

Larkin, P. M. "An Account of the Zande." Sudan Notes and Records, 9(1926): 1-55; 10(1927): 85-135.

McKim, Fred. San Blas: An Account of the Cuna Indians of Panama. The Forbidden Land: Reconnaissance of Upper Bayano River, R. P, in 1936. Edited by Henry Wassen. Boteborg: Etnografiska Museet, 1947.

Marshall, Donald S. "Cuna Folk: A Conceptual Scheme Involving the Dynamic Factors of Culture as Applied to the Cuna Indians of Darien." Ph.D. dissertation, Harvard University, 1950.

Marshall, Lorma. The !Kung of Nyae Nyae. Cambridge, Massachusetts: Harvard University Press, 1976. 
Masters, William M. "Rowanduz: A Kurdish Administrative and Mercntile Center." Ph.D dissertation, University of Mi chigan, 1953.

Merriam, Alan P. An African World. The Besongye Village of Lupupa Ngye. Bloomington, Indiana: Indiana University Press, 1974.

Metraux, Alfred. "The Caingaing." In Handbook of South American Indians, V. I. Edited by Julian H. Steward, 1946.

Mirsky, Jeanette. "The Ammassalik Eskimo of Greenland." In Societies Around the World. Edited by Howard Becker. (a new shorter edition) New York: The Dryden Press, 1956.

Morgan, Lewis H. League of the Ho-da-no-san-nee or Iroquois. 2 vols. Edited and annotated by Herbert M. LLoyd: New York: Dodd, Mead, 1901.

Munro, Neil G. Ainu, Creed and Cult. Edited by B. Z. Seligman. Introduction by H. Watanable. New York: Columbia University Press, 1963.

Murray, Louise $W$. The San Blas Indians. Athens, Pennsylvania: Tioga Point Museum, 1925.

Noon, John A. "Law and Government of the Grand River Iroquois." Indian Notes and Monographs, 2(1920): 103-108.

Nordenskold, Erland. An Historical and Ethnological Survey of the Cuna Indians. Edited by Henry Wassen. Preface by Walter Kaudern. Editory Chapter by Henry Wassen. Goteborg: Goteborg Museum, Etnografiska Avdelningen, 1938.

Nordenskold, Nils, Adolf E. The Voyage of the Vega around Asia and Europe with a Historical Review of Previous Journeys along the North Coast of the Old World. Translated by Alexander Leslie. New York: Macmillan, 1882.

Paulme, Denise. [Social Organization of the Dogon. (French Sudan)] Paris: E'ditions Domat-Montchrestien, F. Lovifon et Cie., 1940.

Pitsudski, Bronislaw. Pregnancy, Birth, and Miscarriage among the Inhabitants of Sakhalin Islands. (Gilyak and Ainu)] Anthropos, 5(1910): 756-774.

Pittier, Henry L. "Known Parts of Panama." National Geographic Magazine, 23(1912): 627-662.

Plog, Fred and Bates, Daniel. Cultural Anthropology: New York: Alfred A. Knopf, 1976. 
Reichel-Dolmatoff, Gerardo. [The Kogi: A Tribe of the Sierra Nevada de Santa Marta, Columbia. v. I]. Institutio Ethnologico National, Revista, 4(1949/1950): $1-319$.

Reynolds; Harold. "Notes on the Azande Tribe of the Congo." African Society Journal, 3(1904): 238-246.

Rosman, Abraham. "Social Structure and Acculturation among the Kanuri of Northern Nigeria." Ph.D. dissertation, Yale University, 1962.

Roth, H. Ling, ed. The Natives of Borneo. Edited from the papers of the late Brookes Low, Esq. Anthropological Institute of Great Britain and Ireland, Journal, 2(1892): 110-137.

Seligman, Charles G. "The Azande." In Pagan Tribes of the Nilotic Sudan. London: George Routledge and Sons, 1932.

Shuman, Malcolm K. "Culture and Deafness in a Mayan Indian Village," in Psychiatry, vol. 43, November 1980.

Simmons, Leo. The Role of the Aged in Primitive Society. New Haven: Yale University Press, 1945; reprint ed., Anchor Books 1970.

Skinner, Alanson. Notes on the Eastern Cree and Northern Saulteaux. New York: American Museum of Natural History, I9I2.

Smith, Mary F. Baba of Karo: A Woman of the Muslim Hausa. With an Introduction and Notes by M. G. Smith. Preface by Darylle Forde. London: Faber and Faber, 1954.

Spencer, Sir Baldwin and Gillen, F. J. The Arunta, A Study of a Stone Age People. 2 vols. The Netherlands: Oosterhout N. B., 1966.

- The Native Tribes of Central Australia. New York: Doner Publications, 1968.

Srivastava, S. K. The Tharus, A Study in Culture Dynamics. Agra: Agra University Press, 1958.

Stefansson, Viljalmur. The Stefansson Arctic Expedition of the American Museum: Preliminary Ethnological Report. New York: American Museum of Natural History, 1914.

Steggerda, Morris. Maya Indians of Yucatan. Washington, D.C.: Carnegie Institution of Washington, 1941. 
Stenning, Derrick. Savannah Nomads. A Study of Wodaabe Pastoral Fulani of Western Province Northern Region, Nigeria. London: Oxford University Press, 1959.

Stewart, Kilton. Pygmies and Dream Giants. New York: Harper and Row, Publishers, 1954.

Stout, David B. San Blas Acculturation: an Introduction. New York: Viking Fund, 1947.

- "Further Notes on Albinism among the San Blas Indians, Cuna, Panama." American Journal of Physical Anthropology, n. S., 4(1946): 483-490.

Sutlive, Vinson H., Jr. "From Longhouse to Pasar: Urbanization in Sarawak, East Malaysia." Ph.D dissertation, University of Pittsburgh, 1972.

Sverdrup, Harold U. [With the People of the Tundra.] Oslo: Gyldendal Norsk Forle, 1938 [I]

Sweet, Louise E. Tell Toqaan: A Syrian Village. Ann Arbor: University of Michigan, 1960.

Talayesva, Donald C. Sun Chief, The Autobiography of a Hopi Indian. Edited by Leow. Simmons. New Haven: Yale University Press, 1942.

Temple, Richard C. The Andamans and Nicobar Islands: Report on the Calcutta Office of the Superintendent of Government Printing; India, 1903.

Thomas, Elizabeth M. The Harmless People. New York: Vintage Books. Division of London House, 1959.

Titier, Mischa. Old Oraibi: A Study of the Hopi Indians of the Third Mesa. New York: Kraus Reprint, 1971. (Reprint of 1944 edition).

- The Hopi Indians of Old Oraibi: Change and Continuity. Ann Arbor: University of Michigan Press, 1972.

Tremearne, A. J. N. Hausa Superstitions and Customs. An Introduction to the Folklore and the Folk. With a new Introduction by Mervyn Haskett. London: Frank Cass and Company, Ltd. ,. 1970.

Tschopik, Harry, Jr. "The Aymara." In Handbook of South American Indians. v. 2. Edited by Julian Stewart. Washington, D. C.: Government Printing Office, 1946: 501-513. 
Vrangel, Ferdinand P. Narrative of an Expedition to the Polar Sea in the Years 1820, 1821,1822 , and 1823. By Ferdinand von Wrangell. Translated from the German by M. Engelhart. Edited by Edward Sabine. London: James Madden, 1844.

Wafer, Lionel. A New Voyage and Description of the Isthmus of America. Oxford: Hakluyt Society, 1934.

Wagner, Gunter. The Bantu of North Kavirondo. Vol. I. London: Oxford University Press, 1949-1956.

Watanabe, Hitoshi. The Ainu Ecosystem, Environment and Group Culture. Seattle: University of Washington Press, 1972.

Waugh, Frederick W. Iroquois Foods and Food Preparation. Ottawa; Government Printing Bureau, 1916.

Williams, F. E. Orokaiva Society. Oxford: At the Clarendon Press, 1930. 


\section{Bibliography \\ (Authors Consulted but not Used)}

Beardsley, Richard K., Hall, John W., and Ward, Robert E. Village Japan. Chicago: University of Chicago Press, 1972.

Geertz, Hildred and Clifford. Kinship in Bali. Chicago: Chicago: The University of Chicago Press, 1975.

Goffman, Irving. Stigma, Notes on the Management of Spoiled Identity. Engelwood Cliffs, New Jersey: PrenticeHall, Inc., 1963.

Groce, Ellen. "Everyone Here Spoke Sign Language." Natural History. 89(June 1980): 10-16.

- "Hereditary Deafness on the Island of Martha's Vineyard: An Ethnohistory of a Genetic Disorder." $\mathrm{Ph} . \mathrm{D}$. dissertation, Brown University, 1983.

Hart, Don V., Rakadhon, Phya A., and Coughlin, Richard J. From Pregnancy through Birth in a Biscayan Filipino Village. New Haven: Human Relations Area Files Press, 1965.

Pelkin, A. The Australian Aborigines. New York: Doubleday and Company., 1964.

Potter, Sulamith Heins. Family Life in a Northern Thai Village, A Study in the Structural Significance of Women. Berkeley, California: University of California Press, 1977.

Ross, Edward Aleworth, ed. The Ways of Man. New York: AppleCentury-Crofts, Inc., 1948.

Sharp, Evelyn. The African Child. An Account of the Intermational Conference on African Children. Westport, Connecticut: Negro University Press, 1931.

Siegal, Bermard J., Beals, Alan R., and Tyler, Stephen A., eds. Annual Review of Anthropology. Vol. II. Palo Alto: Annual Reviews Inc., 1982.

Sussman, Marvin B. ed. Sociology and Rehabilitation. Published by American Sociological Association in cooperation with the Vocational Rehabilitation Administration. U. S. Department of Health, Education, and Welfare. VRA Grant No. RD-1684-G.

Wellin, Edward. "Theoretical Orientations in Medical Anthropology: Continuity and Change over the Past Century." In Culture, Disease, and Healing, Studies in Medical Anthropology. Edited by David Landy. New York: Macmillan Publishing Co., Inc., 1977. 
Whiting, Beatrice B., ed. Six.Cultures. New York: John Wiley and Sons, 1963. 


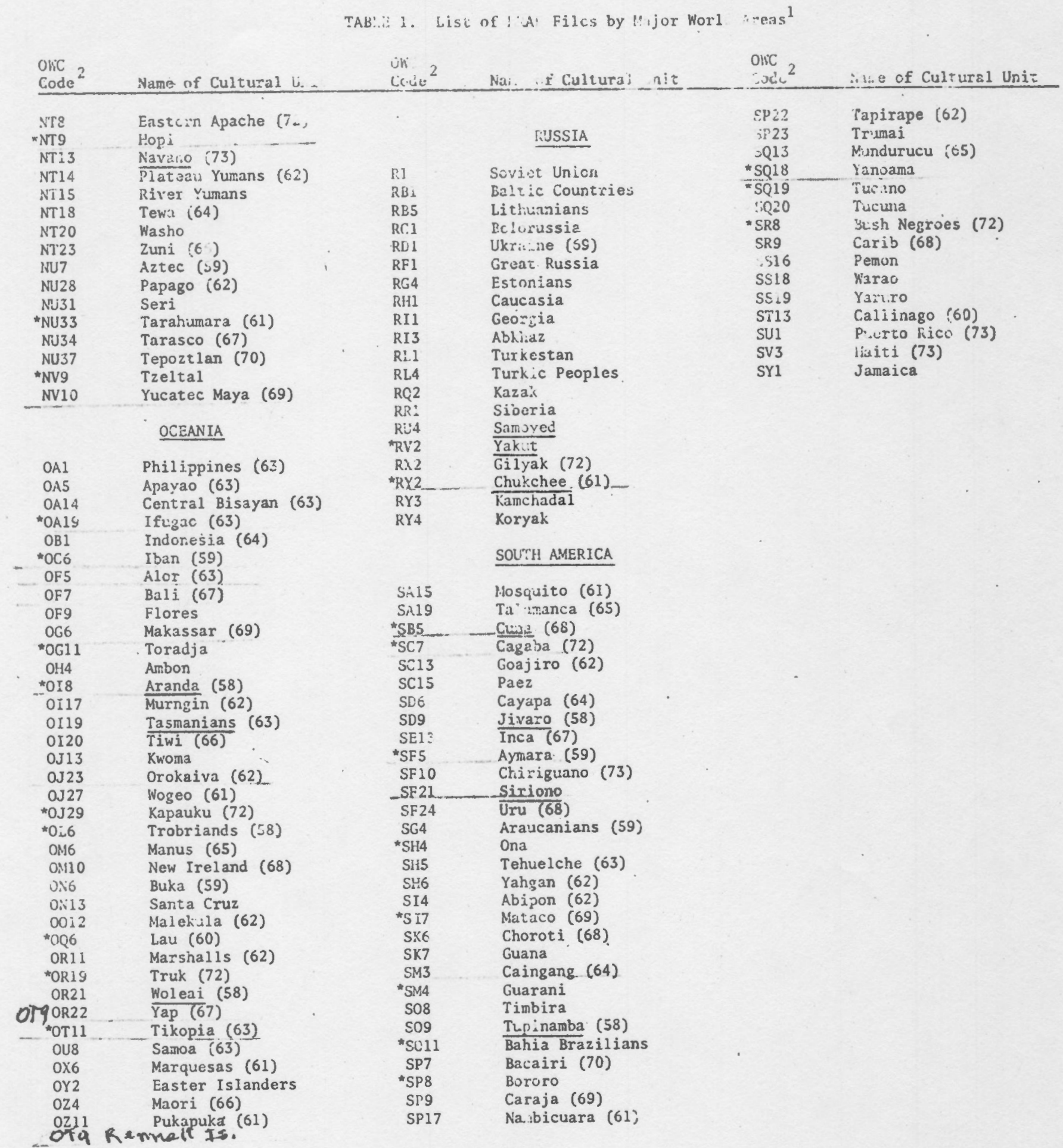

1 The eight major world areas are :' ose delincated in the Our'ine of World Cultures.

2 These are the alphisumeric corle lesignations for the respective cultural units as lisfed in the Outline of World Cultures.

3 Files also included in the IIRAT-Vicrofiles Collection as of 1973 are indicated by the :thunal series numpler in parentheses following the name of the cultural unit.

4 Unde:lining of the cultural unit name inclicates a Fïle macle uy substantially of old style fïle pagges.

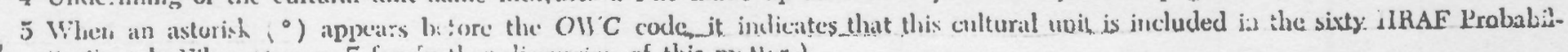

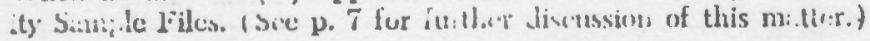


SUMANAT:

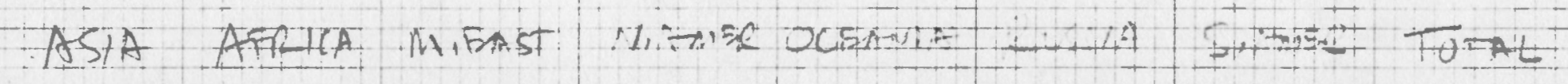

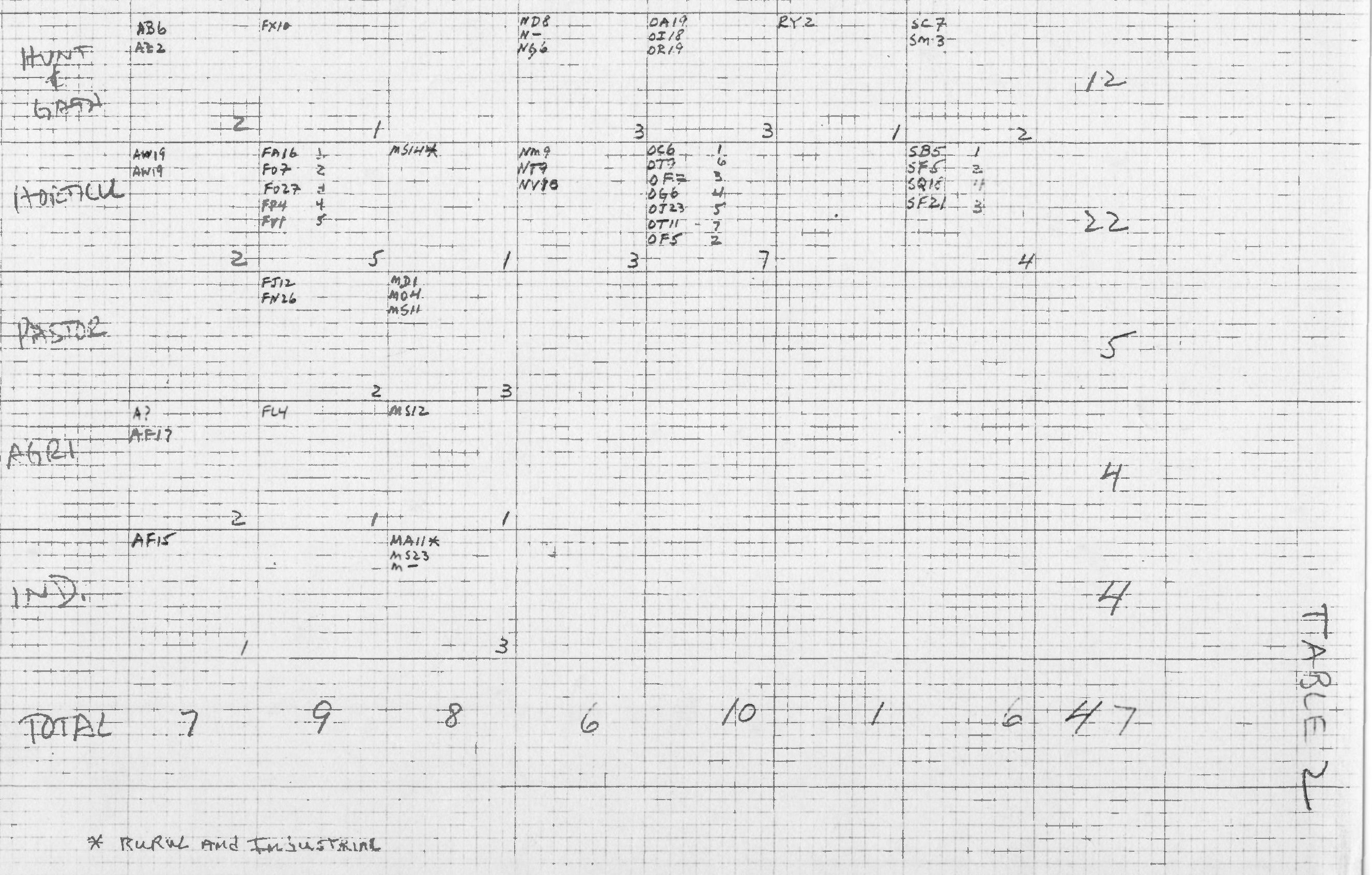


TABLE 3

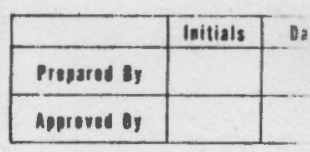

CROSS CULTURAL PATTERNS

OF

DISABILITY

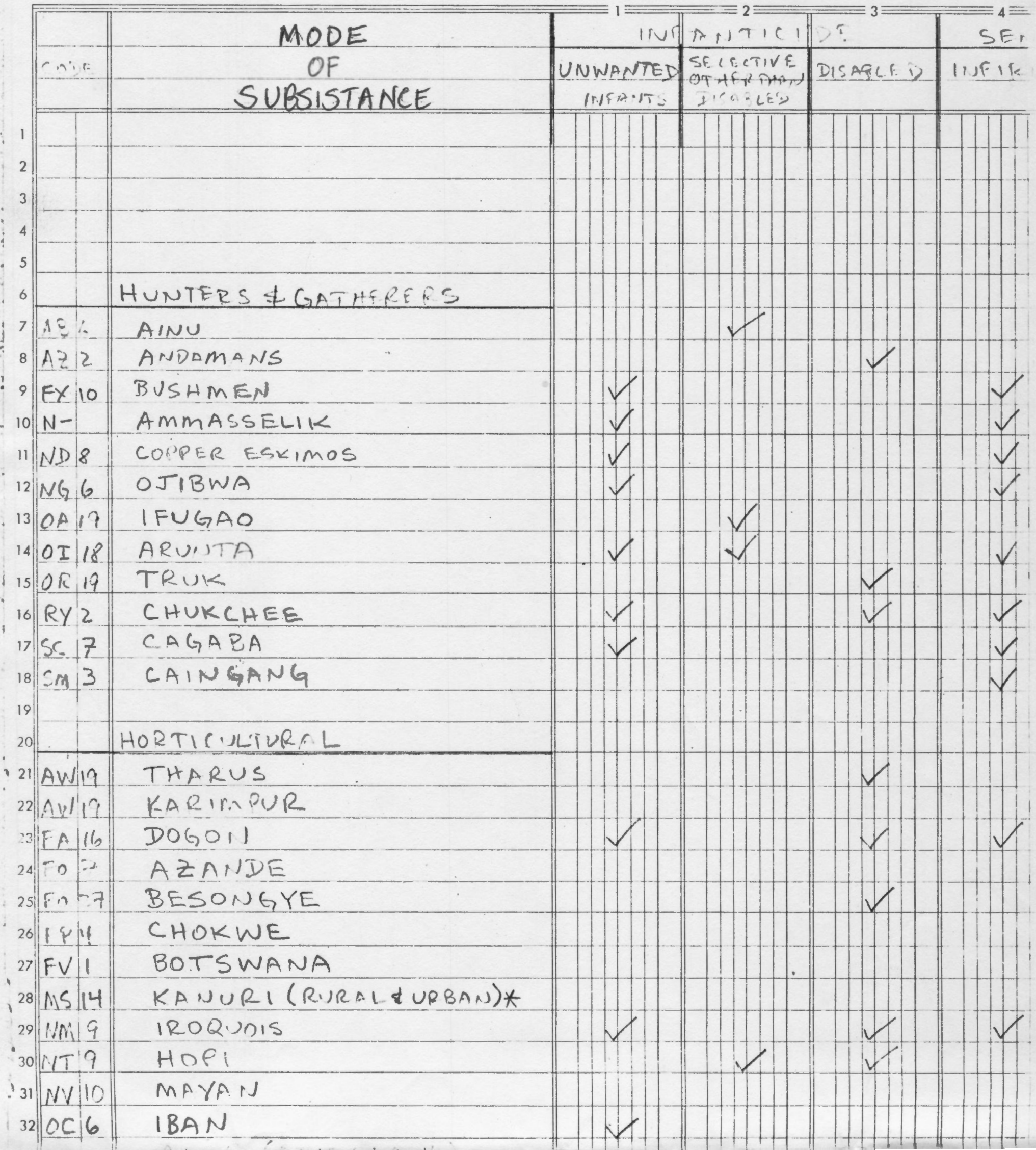




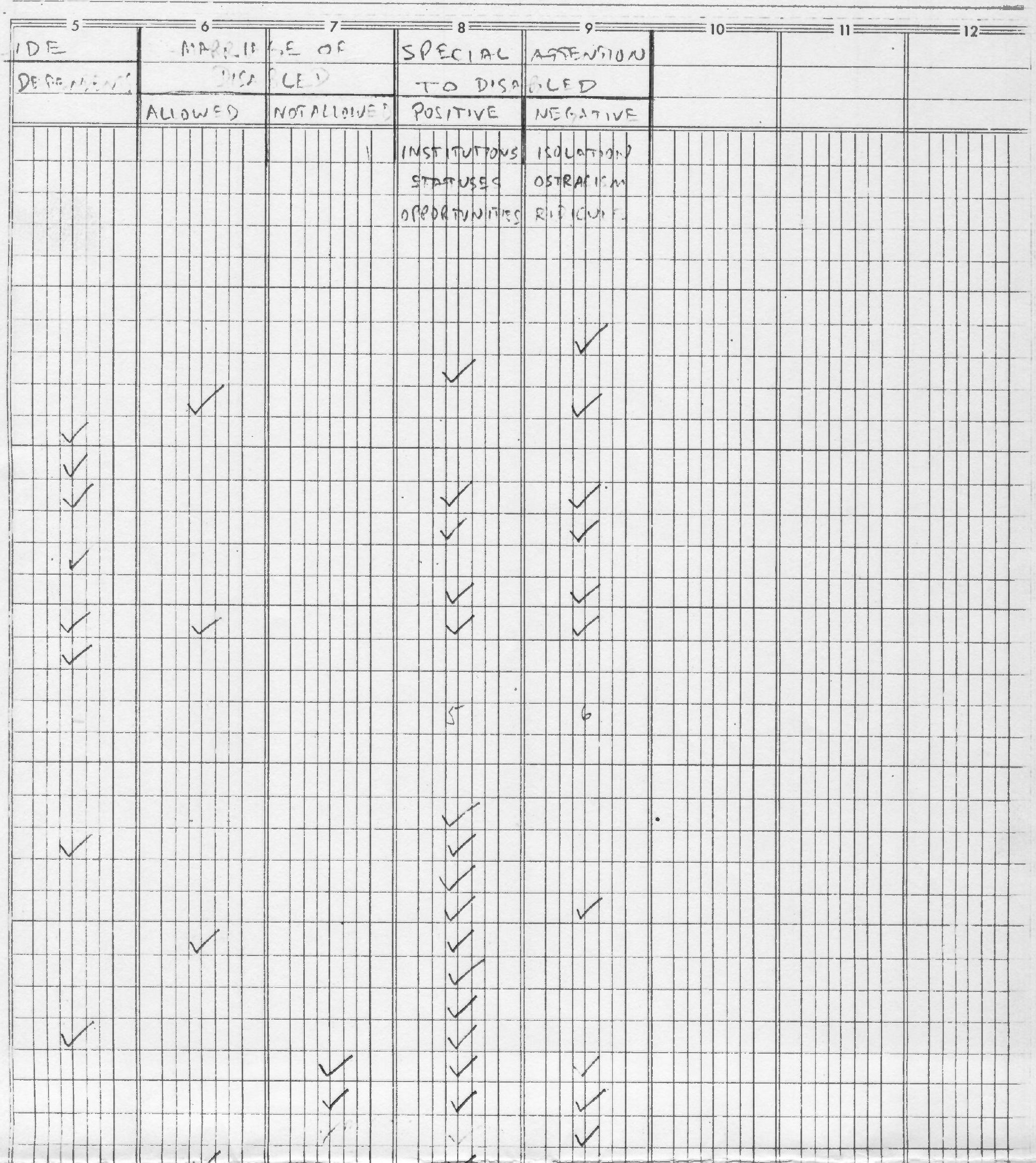


TABLE 3

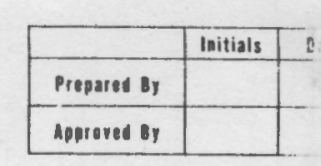

* A Ross cultural PATTERNS

OF

DISABILITY

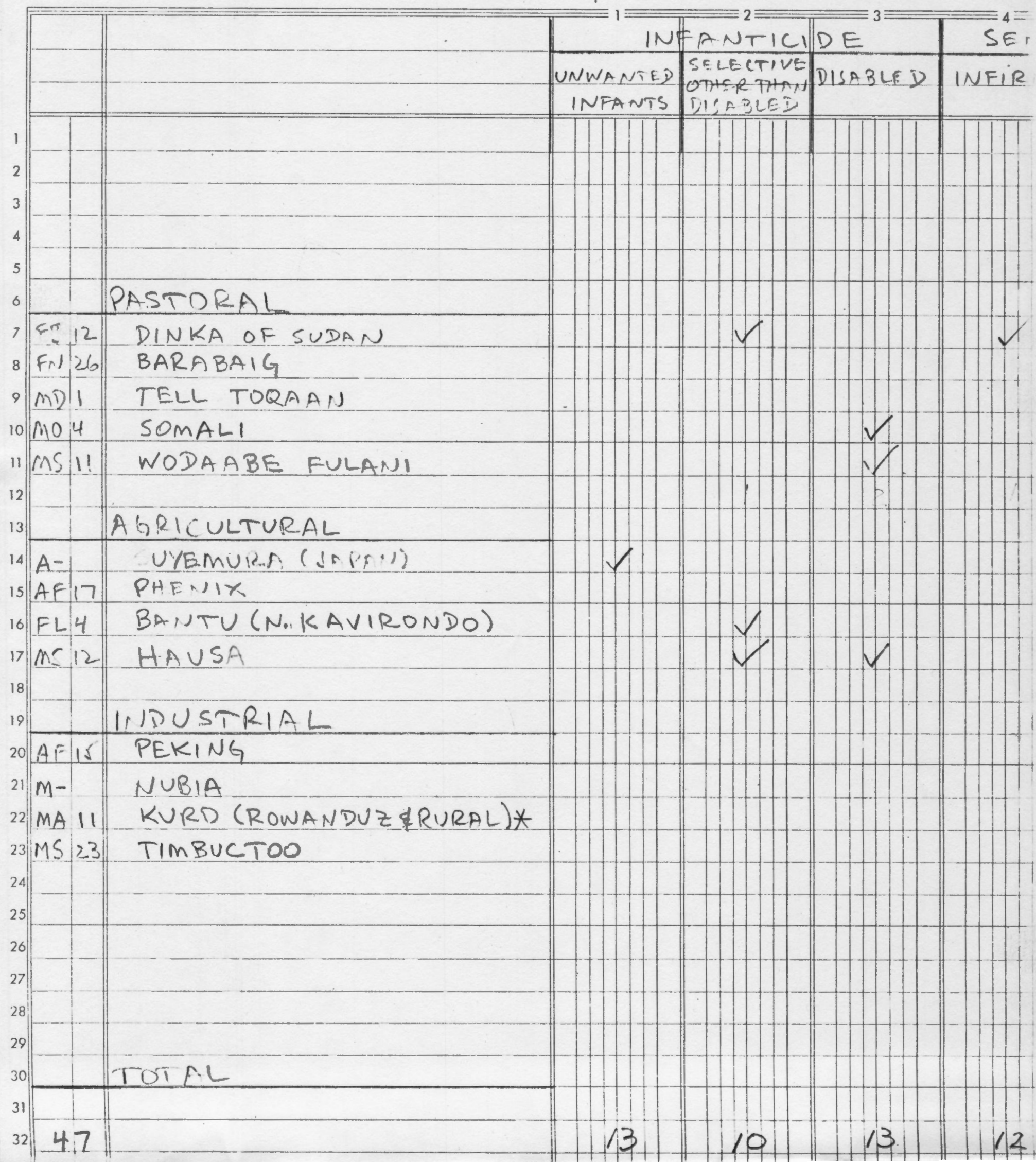


TABLE 3

(2)

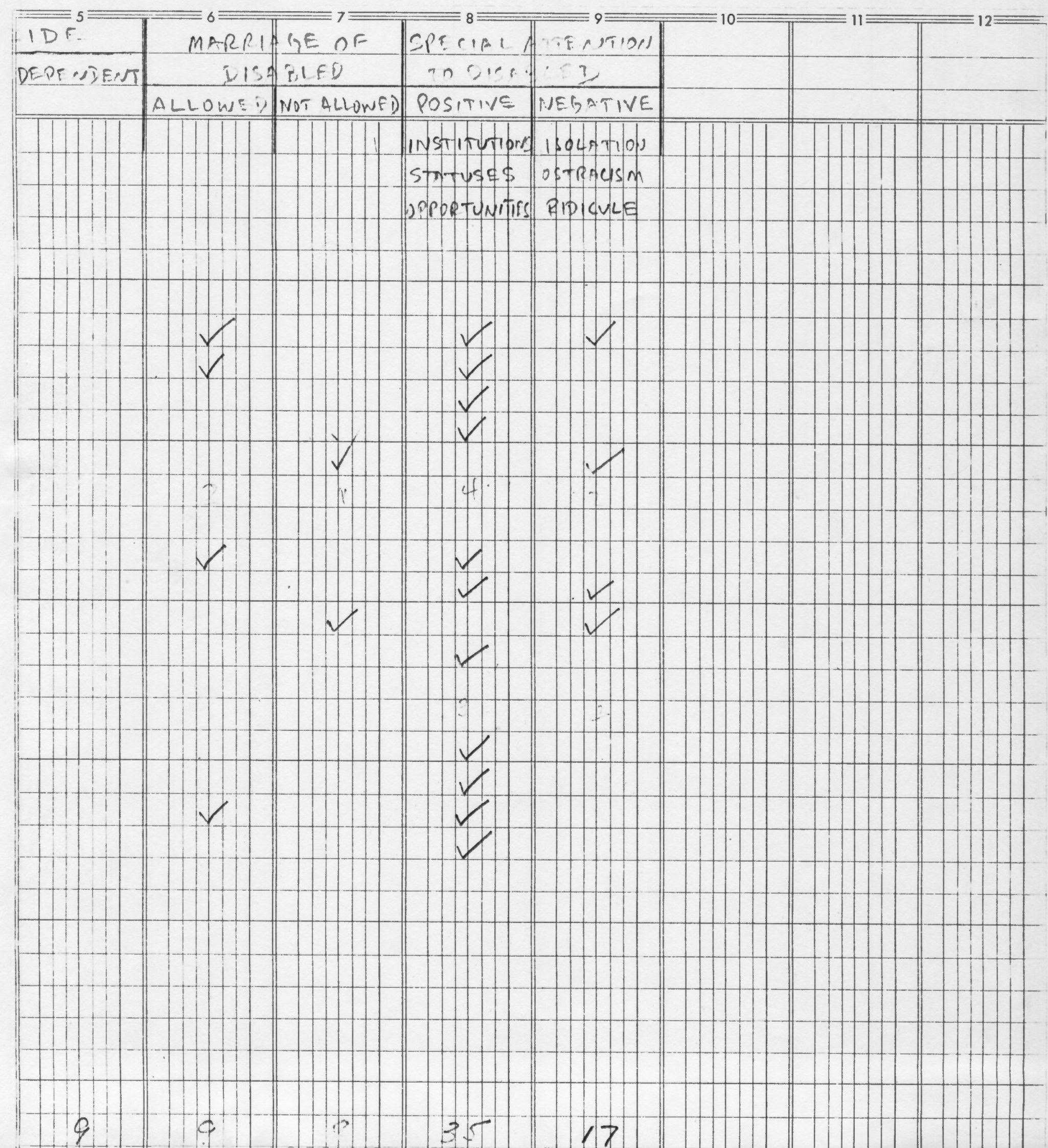


Just.t. 2: Batchelor

Reference:

Jisability

Group Data

Asià

AB6

HRAF Code: AB6 Card: 047 Category:

Japan

Name of Culture Unit: AInu

Ainu

Location of group, society, culture: Hokkaido Island

Time Frame: (1877-1924).1927

Type of Society: Means of Subsistence: Fishing, hunting, gathering

Number and/or Type of disabled persons: Numbers not given.

Types: mad persons

Special Attention to Disabled:

Positive:

Negative: "TX,ing up with cords and beating was the most common method of punishing offenders. - The mad were sometimes treated in this way." (38?)

General Infanticide/Senilcide:

Infanticide/senilicide (disabled only):

Comments:

Other Punishment resulting in disability: 1) "for breaking into a granary (second offense) "sometimes the tip of the nose or the lobes of the ears were cut off and the offender was driven out of the village and boy cotted." (38?) 2) "For murder it was customary to cut the tendons of $t$ feet, thus maiming the culprit for life. The tendons were severed close to the heels. This was a terrible punishment for a persons . . could not possibly do any work or go hunting. He was a burden both to himself anc to his friends. . I saw one man. . he had to crawl about on his hands and knees." (38-39?) 


\section{HRAF Code: AB6 Card: 048 Category: 732, 847}

Name of Culture Unit: Ainu

Location of group, society, culture: Hokkaida Island, Japan

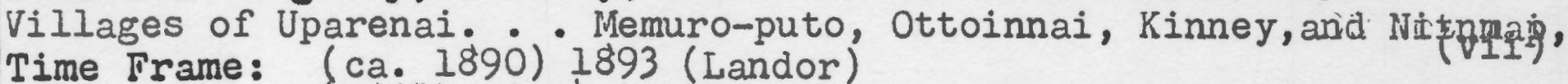
(188क्षै) 1891) (Hitchcock)

Type of Society: Means of Subsistence: fishing, hunting (HItchcock: 467)

Number and/or Type of disabled persons: Numbers not mentioned; Types: "Abnormal formations are sometimes transmitted to many members of one tribe (athor ascribes to intermarriage). . . the harelip and webbed fingers of which deformities twor or three specimens could be found in a small village numbering fifteen to twenty houses."(267) Malformation of the umbilicus is common. . ." Leproxy, common. (270) Spexial Attention to Disabled:

Positive:

Negative: Mentally disabled not treated well; "the unfortunate creat ture, thus afflicted seems to lose not only the respect, but also the pity, as well as care of all the others, and is treated by them as a worthless animal." (vii).

General Infanticide/Senilcide: Author mentions a lot of abortion but does not mention infanticide. (296)

Infanticide/senilicide (disabied only):

Other than leprosy,

Comments: The abnormalities mentioned by the author are not necesaarily disabling unless considered to be so by the Ainu. A hare-lip may be considered a disfigurement in the West, but is it considered to be such elsewhere?

other 


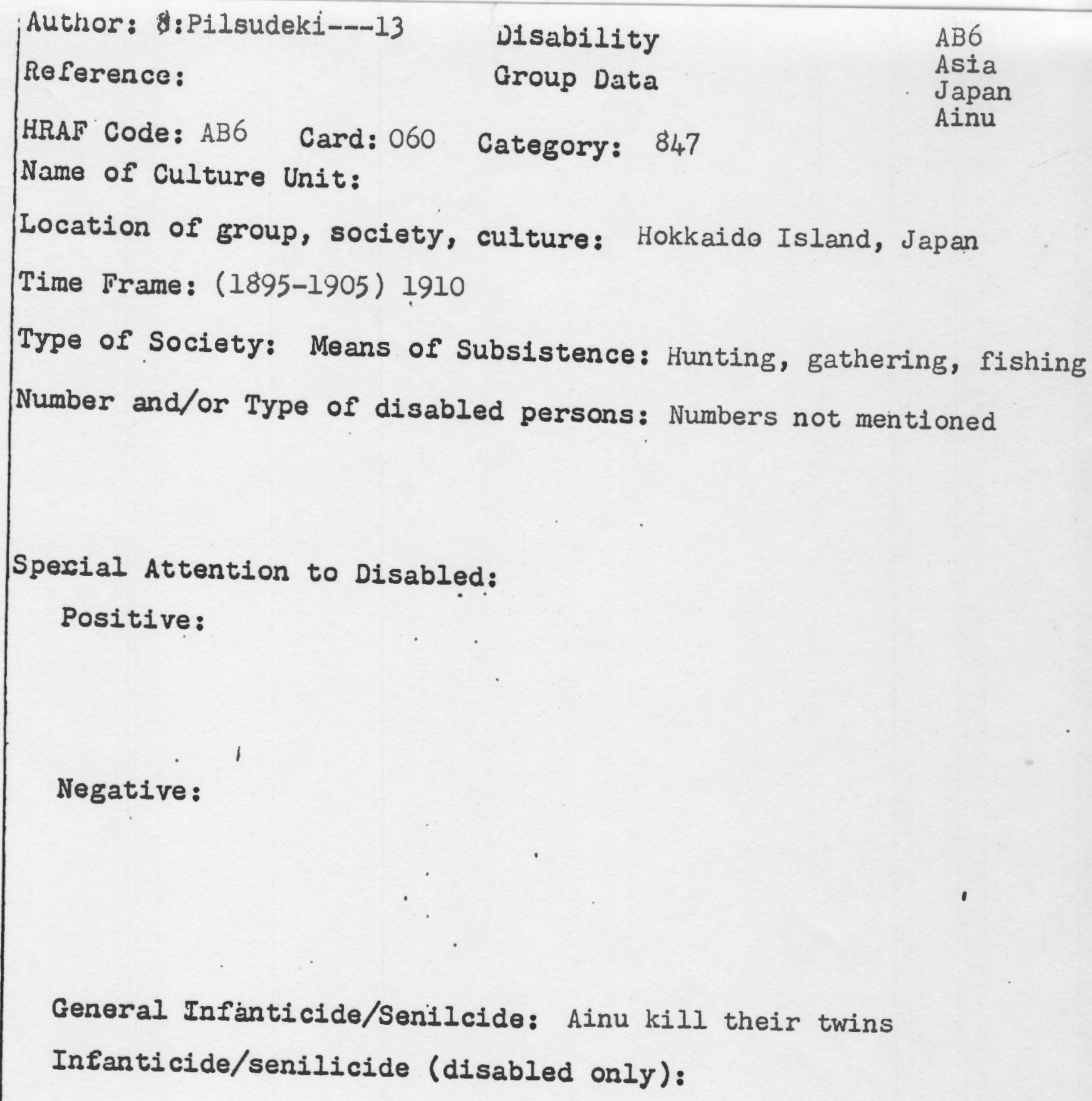

Comments:

Other 
Author: Munro, Neil G.

Disability

Reference: Ainu, Creed

Group Data

Japan and Cult

HRAF Code: AB6 Card: Category:

Name of Culture Unit: The Ainu

Location of group, society, culture: Hokkaido Island, Japan

Time Frame: 1930's to $1944^{\prime} \mathrm{s}$ teathes

Type of Society: Means of Subsistence: hunting, fishing, gathering later (bare subsistence asy iculture)(xi)

Number and/or Type of disabled persons: Number not mentioned Epidemics from measles, whooping cough, smallpox, typhoid cause disabilities and are mentioned, but none of the disabled. (49) Unconsciousness or sudden seizure mentioned. (49) Deaf and dumb are mentioned, not specifically, but caused from not following proper marriac patterns. (149) Psychoneurosis (161)

Special Attention to Disabled:

Positive: Special praygers, exorcism used to help victims of disdease, accidents, childbirth that might have resulted in disabilities.

Negative: If marriage regulations not followed, it was believed tha children from the marriage would have some misfortune: deaf and dumb in one case and a child with a harelip in another(149) "the breach of matrilineal exogamy" would have been "punished by death in the old day $(148)$

General Infanticide/Senilcide: Infanticide/senilicide not mentioned, but does not seem probable. (12I) Elders respected. Infanticide/senilicide (disabled only):

Explanation of disabilities/disease/misfortune: "Paralysis and rheumatism were generally attributed to a cantankerous dead person. Smallpox the most dreaded of plagues, though chiefly inflicted by Pakpro Kan was also thought to be die to the action of lost souls. " "(122) comments:

\section{pther}


Author: 7: Munro and Reference: Seligman

HRAF Code: AB6 Card: 046 Category: 755

Name of Culture Unit: Ainu

Location of group, soclety, culture: Hokkaida Island, Japan

Time Frame: (1900-42) 1963

Type of Society: Means of Subsistence: Hunting, gathering, fishing Number and/or Type of disabled persons: not mentioned:

Sperial Attention to Disabled:

Positive:

Negative:

General Infänticide/Senilcide:

Infanticide/senilicide (disabled only):

Comments:

Other Cause of Disability: Where there is serious illness, mind or bod (the Ainu) are quick to suspect the action of a cantankerous or evil spirit). Purification (exorcism) is necessary for the expulsion of suc spirits, or their influence, from humans, places, or things.: 
$\begin{array}{lll}\text { Author: Etter, Carl } & \text { Disability } & \text { Japan } \\ \text { Reference: Ainu Folklore } & \text { Group Data } & \text { Ainu } \\ \text { Traditions and CuIture of the Vanishing Aborigines of Japan } & \text { AB6 }\end{array}$

HRAF Code:AB6 Card: Category:

Name of Culture Unit: Ainu

Location of group, society, culture: Kurile Islands, and Saghalien

Time Frame: c. 1949

Type of Society: Means of Subsistence: Hunting, gathering, fishing

Number and/or Type of disabled persons: 1/mentioned who hom (a maid in the house) burned w/ a pressure cooker (138)

Sperial Attention to Disabled:

Positive:

Negative: Burned woman feared that the scars (disfigurement rather than a disability) "would prevent her from becoming a bride" "If the scars were noticeable, the Japanese boyds would think she was possesse
by a demon."

General Infänticide/Senilcide:

Infanticide/senilicide (disabled only):

Comments:

Other 
Author: Embree, John F.

Disability

Asia

Reference: Japanese Village Group Data

Suye Mura

HRAF Code: Card: Category:

Name of Culture Unit: Village of Suye Mura

Location of group, society, culture: Suye Mura Village, Kuma County, Time Frame: c. $1940^{\prime} \mathrm{s}$

Japan, Kyushu Island.

\section{Type of Society: Means of Subsistence: Agriculture}

Number and/or Type of disabled persons: There: are a few cripples an feebleminded in Suya Mura; One deaf and dumbrwoman and "a feebleminded boy, more handicapped by blindness than a weak mind. . ."(129) "Iany cases of insanity and most of hysteri are clearly due to sexual maladjustments." $(175-176)$

Spexial Attention to Disabled: "Physical malformation does not necessa ily disqualify one from a:normal life in Suye; there is a blind priest

Positive: Deaf and dumb woman "runs her household remarkably well. \$he had had two successfve husbands, attends all buraka functions, and talks with friends by means of graphic hand signs. She even dances at the drinking parties. The blind/feebleminded boy has been given job as permanent nursemaid in his household.

The blind priest (kitoshj) is the most popular and influential one in 25 Thegative: The villagers believe in witchcraft andipresumably . Suy could bring sickness and death or disability; the latter was not specifically mentioned. (192)

General Infanticide/Senilcide: "There is practically no known infan ticide in the Mura; last case occurred with an "insane mother. (1;.

Infanticide/senilicide (disabled only): Does not appear to be.

Religious Practices: "Wayside Stones. The stone Jizo' is one of the cor monest of roadside images. . . Jizo being a stone is deaf.. . He is cor sidered to be a god who can cure deafness. If a man is deaf or growin. leaf, he sbauld collect particular kinds of stone and present them to $\mathrm{Ji}$ Comments: and he will be cured of deafness. $246-247$

Kitoshi are healing priests and"is usually the keeper of a small shrinc or temple; they may be either Shinto or Buddhist.(187) "In Suye the m. popular Kitoshi is a blind one. $\cdot$ in Oade.(188) The temple is one 0 ten surviving from an original 16 in Kuma County and is said to be 300 years old. Formerly these temples had only blind priests, but more reOther cently seeing priests have come in. The keeper of the Oade temple was adopted by the former blind priest as that priest did not have a blind son, but the present heir apparent is the blind priest's son who is not blind."(189)

*1633: Tokugawa Regime; laws passed to prohibit infanticide,"but economic necessity continued stronger than law or parental love."(4-6)

"Peasant farmers had a very rough time" during that period.

Flderly practice sanfition of "ridicule; elderly not subject to ridicule Hafter man or woman freaknes sixty-one, he or she does and says pretty much what he or she.likes."(172) argument against practice of senilcide 
Author: Embree, John F. Disability

Reference: Japanese Village, Group Data $A B$ Suye Mura

HRAF Code: Card: Category:

Name of Culture Unit: Japanese village of Suye Mura

Location of group, society, culture: Suye Mura Village, Kuma County, Time Frame: c. 1940's (field work: 8-1935 to 12-1936)

Type of Society: Means of Subsistence: rural, farming district

Number and/or Type of disabled persons: Number not known. In Suye Mur healing priests are known as Kitoshi; "In Suye by far the post pppuli and influential kitoshi is a blind one in the little Tendai temple in Oade."(188) "Formerly these temples had only blind priests*, but more recently seeing priests have come in. The keeper of the Oade temple was adopted by "togformer blind priest as that priest did not have a Spexial Attention to Disabled:

Positive: Suye or Japanese village society have made a role for the blind and it is appropriate for them to serve as Kitoshi; "The blin priest is so busy at his business that he follows no other occupation;" some of the other priests are farmers. The Kitoshi do not occupy a high social status.(190)

Negative:

General Infänticide/Senilcido:

Infanticide/senilicide (disabled only):

Comments: The Buddhist religion followed by the villagers allows them to designate wayside stones to protect the villagers from harm. "The stone Jizo is one of the commonest roadside images. . . Jizo, being of stone is deaf. . He is considered to be a god who can cure deafness. If a man is deaf or growing deaf, he should collect stones with holes them and present them to some particular Jizo--not all Jizo will do-Other and he will be cured of his deafness." (184)

* "The temple is one of ten surviving from an original sixteen in Kum: County and is said to be three hundred years old. Formerly these temp had only blind priests. . "**This leads one to believe that there were a large number of blind persons in the Kuma area. **(189) 
Author: Burgess, John S.

Disability

Asia

The Guilds of Peking

Rererence:

Group Data

China

AFl5

HRAF Code: Card: Category:

Name of Culture Unit: Guilds for blind in Peking

Location of group, society, culture: Peking, China

Time Frame: Spring, 1919

Type of Society: Means of Subsistence: Urban;

Number and/or Type of disabled persons: Number not known, but the executive council was composed of $48 \mathrm{men}$. Gild of Blind was composed 0 blind persons who made their living by singing, story telling and entertaining.(103)

Spexial Attention to Disabled: Singing, story teliing and entertainin were evidently considered appropriate roles for the blind.

Positive: Establishment of gild for blind persons; It was a highly organized group, in fact "the most complicated and detailed of any gui in the city."(103) The gild conducted business, held court, socialize at their meetings; helped its members who were in economic trouble $/$ who "have received unjust injury inflicted by others."(131) Gild required members to serve apprenticeship and had high standards. $(137,160)$

Negative: The master was not responsible for accidents that apprentices might suffer such as"being run down in the streets."(160)

"In the olden days, the gilds used to punish their younger members whe convicted of violating the important rules of the association, by sentencing them to 50,70 or 100 strokes of the bamboo, according to the degree of their guilt. The older members were punished by a fine. "( 1 .

General Infänticide/Senilcide:

Infanticide/senilicide (disabled only):

Comments:

other 
Author: 1 Kulp, Danie1 H. Disability

Roference: Country Life in

Group Data AF 17 South Chin

HRAF Code: AF17 Card: 002 Category: 847,888

Name of Culture Unit: Phenix village

Location of group, society, culture: Phenix village outside city of Chaochan, South China (Pukien Provinces) Kwantung, China.

Time Frame: c. 1925 (1918-19)

Type of Society: Means of Subsistence: Arutgrowif, a gricultwe

Number and/or Type of disabled persons: "Nearly 5\% of the total popul tion are defective and leprous. (see attached chart)

(cripples, w/harelip, phys. abnorma.

Special Attention to Disabled: "They/are set off from the rest of the population by their physical peculiarities and marked for spec. attn. Positive: Evidently, there is some sort of community system for $(54$ caring for dependent persons.

Negative: Dependents or persons with physical disabilities are set apart from the larger community. "In addition to the dependence they suffer because of the degree of t: inadequacy, they suffer feelings of inferiority that develop in them abnormal psychic traits. Especially. . true of the marginal cases such as cripples, people with harelip, and the otherwise physically at normal. (54)

General Infánticide/Senilcide: not mentioned "No cases of infanticide in Phenix Village known; no senilicide*

Infanticide/senilicide (disabled only): not mentioned

Comments: * "Old age is one of the chief family values; every attention is bhowered on the aged so that their lives may be long among their children. They are considered an honor not a burden." (200)

Other 
Author: Srivastava, S.K.

Reference: Thamis, A Study in Cultural Dynamics

HRAF Code: AW19 Card:

Name of Culture Unit: Tharus pisability

Group Data

Category:
AW 19

Asia

India

Uttar Prade

Naini Tal

District

The Tarai

Location of group, society, culture: The Tarai, Government Estate in the Naini Tal district of Uttar Pradesh (INdia)

Time Frame:

c. 1950's

Type of Society: Means of Subsistence: Hunting, fishing, collecting forest fruits and roots, stock-raising and a crude form of agriculture Númber and/or Type of disabled persons: Not mentioned. (number)

Type: deformed infants; the tillagers experience many diseases and and epidemics some of which could lead to disability, providing the victims survive. Epidemics such as smallpox often result in deafnes blindness, or both; the author does not mention such disabilities. He does mention that adults suffer from eye diseases.(222)

Spexial Attention to Disabled:

Positive: More often than previously the Tharus are acceptin medic: treatment provided at the Estate dispensaries of Khatima, Sitarganj an Nanakmata, but they are still afraid of inoculations and other methods of prevention and cure.

(233)

Negative: "Abnormal births among the Tharus are of rare occurrence

1) but whenever they occur they create consternation not only the family but in the neighbourhood."('129 Superstitions about abnormal

births cause the infant to be neglected so it will die.

2) In arranging marriages an intermediary is hired to determine among other things whether "members of either family is suffering from lepros that they are not inflicted with evil spirits, and that the girl and th boy to be engaged do not suffer from a physical disability. "(14l)

General Infanticide/Senilcide: Author states that unnatur al vices. . infanticide are very unusual, non-existent among them. ( 24 Infanticide/senilicide (disabled only): "The death of such a child hastened by showing to it every possible neglect. The mother does no give her milk and does not keep the child with her. Sometimes the child is even buried alive in an earthen pot. They believe that if it allowed to live some disaster will follow. . such events are a "rarc

p.247-Foccurrence and author mentions that infanticide is very unusual, rather non-existe

comments: "The common belief is that the evil spirits affect the child

in the womb, deform it and fill it with their own demoniac qualities and so the child comes to have the name of RAksa which means demon.' (130)

Other The Tharus trace disease and epidemics to evil spirts who punish thepeople for any untoward behavior. Different deities cause differer things: "Sitala is responsible for small-pox; Purwa causes insanity, which is rare." $(224-225)$

"Indigenous prescriptions cited by the author prove the prevalence of abled persons: For Paralysis... they tie up the paralysed limbs with 7 ropes; they mix the roots of tobacco, white brinjal and 'ghunghuchi' the patient to drink."(232)

Note: Evidently author does not consider extreme neglect of abnormal infent as infanticide. 
$\begin{array}{lll}\text { Author: 2: Wiser and Wiser } & \text { Disability } & \text { AWl9 } \\ \text { Reference: } & \text { Group Data } & \text { Asia } \\ \text { India } & \text { Uttar } \\ \text { HrAf Code: AWl9 Card: } \quad \text { Category: } 732 & \\ \text { Name of Culture Unit: Village of Karimpur } & \\ \begin{array}{l}\text { Location of group, society, culture: United Provinces, a village eas } \\ \text { of Agra in North India }\end{array}\end{array}$

Time Frame: (c. 1925-1930) 1930

Type of Society: Means of Subsistence:

Number and/or Type of disabled persons: 1 mentioned. Blind girl.

\section{Sperial Attention to Disabled:}

Positive: Kept with family who tried to find a husband for her, which parents considered "their greatest obligation to her." (121)

Negative: Missionaries wanted to send child to blind school, but parents refused in the event they might find husband for her.

When a prospective husband was found; it war found that he was a thief and was sent to jail. .

Difficult to marry Shanti with "her disfigurement." (sightless eyes)

2) elderly widow who "would no longer work, cast off." (83)

General Infanticide/Senilcide: Not mentioned.

Infanticide/senilicide (disabled only):

Comments: 1) Caste system in India might detemine how infants and elderly treated; elderly widows with no male relatives may have a diffi cult time: " missionaries knew of only "one widow tho had been cast 0 because she could no longer work."(83)

Other 
Author: Man, H. Roference : HRAF Code: AZ2 Card: Category: 757, Name of Culture Unit: Andamans Location of group, society, culture: Andaman Islands Time Trame: (1869-1880) 1932

Type of Society: Means of Subsistence: Hunters, gatherors, fishers Number and/or Type of disabled persons: "Two or three cases of hunchback or lateral curuabure of the spine. . "(14)

"Pathology.--1. No idiots, maniacs, or lunatics have ever yet been observed among them, and this is not because those too afflicted are killed or confined by their fellows. . "(14)

\section{Sperial Attention to Disabled:}

1)

Positive: The aged, sick, helpless are evidently cared for by the

2) society. (14)

"Their method of treating epilepsy is to sprinkle the patient with col water and then scarify his brow. "I (Not persecuted or isolated)

\section{Negative:}

General Infanticide/Senilcide: No infanticide/senilicide because the "greatest care and attention are invariably paid to the sick, aged, an Infanticide/senilicide (disabled only): helpless."(14)

"It seems hardly necessary to add that the unnatural cusbum of infantic is unknown to the Andimanese. . . lavish attentions bestowed on the lit ones by their ighorant but well-intentioned elders."(109)

\section{Comments:}

\section{Other}


Author: 3: Temple

Reference:
Disability

Group Data

HRAF Code: AZ2 Card: 014 Category:

Name of Culture Unit: Andamans

Location of group, society, culture: Andaman:Islands

Time Frame: (1901) 1903.

Type of Society: Means of Subsistence: Hunters, gatherers, fisher

Number and/or Type of disabled persons: Numbers not cited.

Types: "epileptics are recognized."

"Idiocy, insanity and natural deformities are rare among them."

Sperial Attention to Disabled:

Positive: ".

Negative:

General Infanticide/Senilcide:

Infanticide/senilicide (disabled only):

Comments:

Other 
Author: 11: Cipriani

\section{Reference:}

HRAF Code: AZ2 Card: 014 Category: 158, 787, 732, 847, 734, 752, Name of Culture Unit: Andamans, Onges 462

Location of group, society, culture: Andamans, Crficieds

\section{Time Frame: (1951-1955).1966}

Type of Society: Means of Subsistence: Hunters and gatherers, fisher.

Number and/or Type of disabled persons: "two cases of abnormalities" mentioned (15)

Epileptics (495)

"two cases of incipient lameness, a young man and a yonng woman."(491) "lcase of dementia in a woman." (495)

\section{Spexial Attention to Disabled:}

Positive: Rather than being persecuted, "Epileptics are considered a 'possessed by spirits who speak through their mouths, and respectuflly question them like the oracie." (495)

2) "Women assume men's work (hunting and fishing) during severe illness of of the husband. Similar help given in care of aged or if wife or mothe ill; food is provided for them."( 49

\section{Negative:}

General Infanticide/Senilcide: No" "twins are gladly. • accepted, s eager are the Onges to have children."(15)

Infanticide/senilicide (disabled only): Author\% thinks so. "premature births are common so are malformations and other anomalies. Imperfect infants are quickly eliminated by their parents. . There are no blind, and deaf and dumb people in little Andaman. . "(49I)

Comments: There is a difference of opinion about practice of infanticid between Man and Citriani, but even if infanticide is practiced, the natives could acquire disabilities from polio, smallpox, measles or other epidemics. (19) Cipriani argues that infanticide probably occurred because "Fear of bepther weight. . " (15) 


\section{COUNTRY LIFE IN SOUTH CHINA}

167 tions; in short, a decadence of fomilism and a forsaken struggle against environment constitute the main disadvantageous tendencies arising from emigration. That they are increasingly costly can readily be admitted; that they can be offiset through trained village leadership wisely exerted is without question.. With such leadership, emigration could be turned from a curse in to a blessing.

\section{HEALTH AND SANITATION}

732 One of the first avenues for improvement in village life could be created by making more sanitary all parts of the village. But before discussing health and village

TABLE VIII

POPULATION: DEFECTIVES AND LEPERS

\begin{tabular}{|l|c|c|c|}
\hline \multicolumn{1}{|c|}{ Types } & Number & \multicolumn{1}{|c|}{ Types } & Number \\
\hline Lepers & 7 & Deal & 2 \\
\hline Ineane & 5 & Harelip & 2 \\
\hline Feebleminded & 2 & Dumb & 1 \\
\hline Cripples & 4 & $\begin{array}{c}\text { Otherwise Physi- } \\
\text { Cally Abnormal }\end{array}$ & 2 \\
\hline Blind & 3 & & 28 \\
\hline Total & & 4.3 \\
\hline Per Cent Total Population
\end{tabular}

732 sanitation-or lack of it-it will be of interest to note types and distribution of infirmities recognized by the villagers to exist in their midst.

Nearly five per cent of the total population are defective and leprous. The most important consideration 
Reference:

Rererence:

$017 \quad 164$

FAl6

HRAF Code: FAl6 Card: O40 Category: $847,732,887-888,2215$
Name of Culture Unit: Dogon

Location of group, society, culture: Dggon, Lower Ogo, Mali, W. Afric Time Frame: (1935) 1940 ; fist conversation, October 1946

Type of Society: Means of Subsistence: Hortishing, hunting, stock raisin

Number and/or Type of disabled persons: Numbers not mentioned.

Types: malformed children; since elderly are held with great respect, aged infirm would be cared for. (not specifically mentioned.) Ieprosiy, smallpox (which leadeto disabling conditions)

Spexial Attention to Disabled:

Positive: Aged infirm probably cared for. ...

Negative: Infanticide of malformed infants.

General Infanticide/Senilcide: ". . 2bortion and infanticide; llthou:

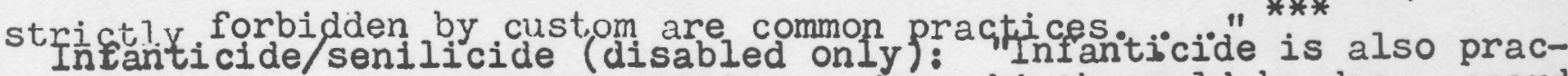
ticed,openly, on malformed children, whose birth would be due, according to a very general belief, to the union, perhaps involuntary, of th woman with a spirit of the bush."(410)

Senilicide not mentioned and probably not practicedbbecause old men held property for group, were respectedciand revered. *

Comments: A poosible explanation for practice of abortion/infanticide despite social disapproval, is thkt/there"rigid convention that birth b regular," that infant be legitimate. "If pregnant and unmarried, woman suffers scorn/ cruel humiliation."

Other *later research: ". . In former times the abandonment of old or infirm individuals was not an unknown practice in the region, and in Sanga people mentioned the case of an old woman who had died of starvation in this way only a few years ago in the village of Koundou." (/89 cont/

***Infanticide rllegitimacy "(if woman) unable to bring about an aborti in the required time, the matrons who assist her during her delivery smother the newborn child immediately."(/433 cont/) 


\begin{abstract}
Author: HRAF guide Disability Reference:

HRAF Code: AB6 Card: Gaîlde Category: Guide to file

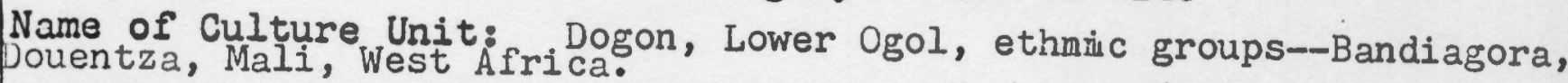
Location of group, society, culture: Lower Ogol, Mali, West Africa

Time Frame: First conversation; October 1946

Type of Society: Means of Subsistence: Horticulturalists

hunting, fishing, stock raising
\end{abstract}

Number and/or Type of disabled persons:

Spexial Attention to Disabled:

Positive: ...

Negative:

General Infäticide/Senilcide:

Infanticide/senilicide (disabled only):

comments:

Other 
Author: Griaule, Marcel

Reference: Conversations

Group Data

with Ogotermele.

HRAF Code: FAl6 Card: Category:

Name of Culture Unit: the Dogon

Location of group, society, culture: Dogon Country, Lower Ogol, West Africa

Time Frame: October 1946 (time of first conversation between Ogotemmê and Marcel Griaule); conversations continued for 33 successive daj

Type of Society: Means of Subsistence: Horticulturalists

Number and/or Type of disabled persons: Ogotemmêli, one of Dogon's elders, a blind man.

Sperial Attention to Disabled: Ogotemmeli's high rank and status testi fy that the Dogon recognize that some of the disabled have unusual Positive: abilitie:

Negative:

General Infänticide/Senilcide:

Infanticide/senilicide (disabled only):

Comments: The purposes of the conversations between Ogotemmêli and Griaule were to acquaint Europeans with important Dogon institutions: custons, and rituals, especially "cosmogony, a metaphysic, and a religion which put them on a par with the pooples of antiquity, and which Christian theology might...study with profit."2

pther 
Reference: 1) Demg: The Dinka Croup Data

of the Sudan 2) Deng: Tradition and Modernization... Dinkas

HRAF Code:

Card:

Category:

Name of Culture Unit: Dinka of Sudan, Ngok, southern tribe

Location of group, society, culture: see map (attached)

Time Frame: contemporary, but with historical/traditional information

\section{Pastoralists}

Type of Society: Means of Subsistence: Cattle raisers (dairy product and mainstay of society), cultivators,

Number and/or Type of disabled persons: numbers not given

Types: epileptic, crippled, blind, drastically deformed (156:Traditior leprosy, tuberculosis(223:Tradition),

\section{Sperial Attention to Disabled:}

1)

Positive: consent is given to marry: epileptic, crippled, blind or drastically deformed persons (considered sppxitually dangerous to objec to marriage. - as it may inflict a curse on the refusing kin.)(156: Traditions):

2) "A sick, aged, or otherwise needy person must be taken care of by his re

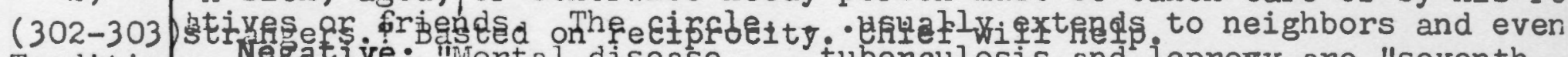
Traditiols Negative: "Mortal disease. : tuberculosis and leprozy, are "seventh 으. 3)* cause for divorse"(180: Traditions) Husband usually persuaded against di vorce in that disease is an "Act of God."(180). Another obstacle imputi disease. . considered defamatory."(180) Parents usually urge children not to marry tubercular or leperous persons; to investigate individual' $s$ background(223: Eraditions)

"physical wholeness. is highly valued and deformity miserably degrading, hunchback is among the most dreaded disease of infancy. "( 43: Tradition)

General Infanticide/Senilcide. Infanticide: yes illigi imate childre exposed in pastj- tody they pray for their death and babies usualiy die.

Intanticide/senilicide (disabled only):

but twins are allowed to live with an elaborate ceremony(ies) connected with them. The Dinka associate having twins "with menttal abnormalities" thus "There would seem to be a link between the fact that it is abnormal to have twins, that such abnormality implies a religious and ritual status, that mental disorders are normally associated with similar religiou colments.

If a "disease (child's) considered curable becomes fatal or uncontrollab moral wrong is attributed to adult relatives or to an envious evil eye." (43: Tha-Dimbain)

1. Other ${ }^{*}$ mpensation is made for bodily injuries(eyes, limbs, teeth)in cour ( 298 ) Traditions.

2. Dinka believe in curers, diviners; "The magician came. He was a bulky, short, and crooked-looking man who must have been born defective and was deformed in almset every way."(129)(Dinka)

**

Senilicide: When elderly become senile"Such old persons, if they are frol modest backgrounds with no extra requirements for respect, run the risk of being viewed as idiots in whom people, especially children, find amus ment... many reasons for the custom. . in part to avoid the degrading consequences of senility in old age that Dinka Chiefs were not allowed t die naturally, but were buried aliye when too old to function or when they thought themselves near death. "(121: Dinka)

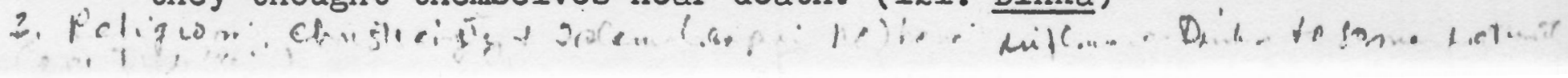


Author: Wagner, Gunter.

Reference: The Bantu of North Kavirondo

HRAF Code:

Card:
Disability

Group Data

Africa

Bantu of No

Kavirondo

FL4

(Nyanza Provinc

Category:

of Kenya)

Name of Culture Unit: Bantu Kavirondo

Location of group, society, culture: Kavirondo is situated to the nort east of Lake Victoria on either side of the Equator, part of Kenya. . Time Frame: c. 1940's

Type of Society: Means of Subsistence: Most fertile area in Kenya. Extensive farming, herd goats/sheep; large scale cash crops. Number and/or 'Type of disabled persons: No numbers mentioned. Types: epilepsy, leprosy, serious ulcers, eye diseases, and accidents.

Spexial Attention to Disabled:

Positive:

Infanticide of deformed infants.

Negative:/A man can be "rejected as a suitor" (marriage) "by the people who know him" if he suffers from a disability; in that case he looks for a wife from a territory distant from his own. Other diseaseas such as epilepsy, leprosy, serious ulcers . . are a "bar against marriage." Such persons "often have to live by themselves in the bush at a safe distance from other homesteads. (392) Epilepsy thought to be contagious like leprosy; insist on such persons being isolated.

General Infäticide/Senilcide:

Infanticide/senilicide (disabled only): Yes. "Deficiences or major abnormalities in a child are commonly attributed to incestuous intercourse. If it is beyond doubt that the marital relationship between hu: band wife does not infringe the laws of exogamy, the birth of an abnor= mal child is quite logically attributed to incestuous adultery on the part of the wife. The child in that case is put to death and the wifecomments: A diviner is consulted in situations in which sudden and violent illness. - eye diseases.. - sudden possession or insanity - . or accidents" occur.(22l-222)

No senilicide since the elders are respected and are leaders. Senilicide not mertioned. (76-77)

Other **undergo a purification ceremony, and a sacrifice is made for her before her husband resumes sexual relations with her. A miscarrlage which occurs suddenly and without causing much pain to the woman is regarded as the consequence of an act of adultery committed by the wife during her pregnancy. It is said in that case that the child was kille in the womb by 'the thighs of her lover. '(297) 
Author: Klima, George J.

Reference: The Barabaig: East African CattIe-Herders HRAF Code: Card:

Name of Culture Unit: The Barabaig, Datog

Location of group, society, culture: Tanzania, East Africa

Time Frame: c. 1970

Type of Society: Means of Subsistence: "Cattle complex" (pastoral)

Number and/or Type of disabled persons: Specific number of disabled not mentioned, but author stresses that infants are born into a "diseas ridden environment" and even if it reaches adulthood, an individual wil never experience good health. Blindness is prevalent; "blind children remain in the Kraal and never go out unacompanied."(52) Blindness occur. among people of al ages, and may be due to veneral infection, aisease sperial Attention to Disabled:

1)

Positive: Elders who reach their fifties are "accorded special rater tim consideration. and deference," which infers that the aged infirm are cared for. ( 46 )

2) Blind children (and adults) appear to be cared for too.(52)

3) "In crises of sickness and disease. . the neighborhood council of men assembles to discuss the issue and arrive at Bome consensus about actio: Negative: Their world (of a blind child) is restricted to the confines of the Kraal and a small area outside the gate."(52)

General Infanticide/Senilcide: Infanticide/senilicide not mentioned; as father loses part of herd to sons at their marriages, he also loses*
Infanticide/senilicide (disabled only):

*authority over his sons and some of his own power and prestige as a cattle owner; this may result in less attention and care as he ages or becomes aged and infirm, but no mention is made of this possibility.

Comments: The high infant mortality rate due to being fed on raw cow's milk immediately after birth, diseases and epidemics, may argue against the practice of infanticide because every infant may be valued, (48) and the weak and disabled infants probably don't survive.

Other Marriage: "Every Barabaig girl must marry, whether or not she is physically desirable. Crippled, deformed, and demented girls must have a wedding in order for them to be eligible to gear the hanah() wend, a There are no unmarried women in Barabaig society." $(64)$ significance. isis 
suthor: Czekanowski:20--56 Disability

Reference :

Group Data

Afr_ca

*Azanide

F07

HRAF Code: F07 Card: 145 Category: 752,847

Name of Culture Unit: Azande

Location of group, society, culture: Faradje,

Time Frame: (1907-08) 1924

Type of Society: Means of Subsistence: Horticulturalists

Number and/or Type of disabled persons: Number not mentioned;

Disability through mutilation: a man (Babandara, (son of Delaw)

who "lost his genitals and both hands. His testicles had been cut

off, as well as his penis. . the mutilated arm stumps. . " (

Spexial Attention to Disabled:

Positive:

Negative: Adultery punished eeverely by mutilating the adulterer.

General Infanticide/Senilcide: Not mentioned, "abortion prevalent" "Even natives consider abortion a punishable offence."

Infanticide/senilicide (disabled only): Not mentioned

Comments: Since legitimacy of bifints is so importanteto the Azande, (but abortion is practiced), that unwanted infants are prevented from reaching the birth stage; they are disposed of through abortion in the early stages of pregnancy.

Other 
Author

21: Evans-Pritchard (88\&)

FO7

HRAF Code: FO7 Card: 145 Category: 736, 888

Name of Cultyre Unit: Azande Location; Azande region bounced by parallels $23^{\circ}$ and $30^{\circ}$ Longitude E. and $2^{\circ} 50^{\prime}$ and $6^{\circ}$ Latitude North. Location of group, society, cuiture: Horticulturalists, cultivate soi kill animals and lish, collect wild fruits, roots, and insects.

Time Frame: (1926-1929) 1937

Type of Society: Means of Subsistence:(see above)

Number and/or Type of disabled persons: Numbers not mentioned.

Type: "Occasionally a man is largely dependent on his blood brothers for the necessities of life. Such a case if that of the mutilated man Bitarar Also," "congenital abnormalities as harelip"

The social institution of

Special Attention to Disabled: "Blood bobthers" provides a method of caring for persons with disabilities who were dependent.

Posltive: B1tarangba "lived with one of his blood bodthers. . .(he)

had exchanged blood with several other neighbours and was always a welcome guest at their meals. Being physically helpless, he had made a point of contracting alliances ofblood with two or three influential ms of the nimghbourhood who were able to assist him through their influenc at court and by their authority in the locality." He was not on "good Negative: terms"w/relatives.

Practice of mutilation

General Infanticide/Senilcide: Infanticide not mentioned, witchcraf combined with age "contrive to put an end to an old man."

Infanticide/senilicide (disabled only): senilicide of aged infirm attributed to $\mathrm{w} / \mathrm{craft}$ insome instances. Azande. not sad about old people who have lived to be elderly; they say they have eaten their 35: fvans-Pritchard. $(1966-1930) 1932$ cardc 184 category 847 would spare would sometimes kill a male child if it were illigitemate by Comments: Azande attribute sickeness, disease, accidents. . to witchcraft except in "diseases which only attack infants. Congenital abnormalities as harelip, constitute exceptions to this general rule in that they are attributed to Mbori (Supreme Being) and recognized as incurable." ( 0 : FML 75; category 753: Theory of Disease)

2) Other "Mutilated individuals, invalids, the impoverished, the aged, and so on, are cared for by the immediate family or by members of the sib. The institution of blood brotherhood absorbs many of these cases. . ." (card 135: category 73:FML 
Author: 10: Anderson

Reference:

Group Data

HRAF Code: FO7 Card: Category: 732, 753(0:FML 75)

Name of Culture Unit: Azande

Location of group, society, cuiture:

Time Frame: (no date) 1911 and (1950)

Type of Society: Means of Subsistence: Horticulturalists

Number and/or Type of disabled persons: Numbers not mentioned. author mentioned: "A supplementary fifth finger or first toe are surprisingly common among these savages who are usually proud of the addition. Acquired disabilities: umbilical hernia in children and prepatellar bursae in women from kneeling; scar deformities are most frequently met. with."

Spexial Attention to Disabled:

Positive: ...

Negative:

General Infäticide/Serilcide:

Infanticide/senilicide (disabled only):

Comments:

"Bodily injuries" "According to Anderson, surgical techniques among the Azande are few in number"...splints applied to fractures, snakebites scarred and sucked. "Severe wounds caused by mutilation were treateg with burning palm oil." This statement leads one to believe that ser.riously disabled persons probably died at birth, when accident occurred, or sickness/disease other Explanations for disability: In addition to bause of accident or dis-
dease, Azande attribute problem to witchcraft and sorcery. If the individual had an accident, the accident occurred because of witchcraft or sorcery and not because the individual fell or whatever. 
Author: 8:Larken- -40

Disability

Reference:

Group Data

HRAF Code: FO7 Card: 067 Category: 158, 481

Name of Culture Unit: Azande

Location of group, society, culture:

Time Frame: (C. 1925) 1926

Type of Society: Means of Subsistence: Horticulturalists

Number and/or Type of disabled persons: Numbers not mentioned;

Types: Exogamy and imbreeding practiced"(only forbidden relation is child of the same mother) Author states: Perhaps owing to imbreeding greater proportion of imbeciles. - . stammering common among them."
category: 158)

Sperial Attention to Disabled:

Positive:

Negative:

General Infäticide/Senilcide:

Infanticide/senilicide (disabled only):

Comments: Aluthor mentions a variety of cangsi. and crttches, "walkingsticks," some ornamented and of interesting shapes "grotesquely exaggerated and twisted." Author did not say if they were used by ablebodied of population or the disabled. Were the canes, crutches, etc., used as an aid in walking or as some type of status symbol?

Other 
Author: 27: De liratr--2)U
Reference:

Spexial Attention to Disabled:

Positive:

Negative:

General Infäticide/Senilcide:

Infanticide/senilicide (disabled only):

comments:

pther 
$\begin{array}{lll}\text { Autbor: 50: Baxter is butt } & \text { Disability } \\ \text { Reference: } & \text { Group Data } & \text { Africa. Fol } \\ & & \text { FOR7 Fade }\end{array}$

HRAF Code: FO'7 Card: 1844 Category: 845,848

Name of Culture Unit: Azande

Location of group, society, culture:

Time Frame: (no date) 1953

Type of Society: Means of Subsistence: horticulturalists

Number and/or Type of disabled persons: numbers not cited.

Type: misshapen children

Sperial Attention to Disabled:

Positive: ...Misshapen children are treasured like sound ones."(72) - (Baxter and Butt)

Negative:

General Infánticide/Senilcide: "Formerly, male child, born of adultery, was generally killed by the husband of the guilty woman. It the only

the only case I know of the murder of a newborn child. It is not the generally not killed." (

Comments:

pther 
Author: Merriam, Alan P. Disability

Reference: An African World Group Data

The Besongye Village of Lupupa Ngye.

HiRA Code: Card: Category:

Name of Culture Unit: Besongye, Bala people (xviii)

Location of group, society, culture: Besongye Village of Lupupa Ngye E. Kasai Region, Republic of Zaire; roughid tet 5 th s $6 \mathrm{~h}$ parallels Sou Time Frame: c. 1959 (July) tó $1960(\mathrm{JuIy})^{4}$ to 270 east.

Type of Society: Means of Subsistence: Horticulturalists (60)

Number and/or Type of disabled persons: Numbers not mentioned.

Types: albinos, deformed child, and so-called deviants.

extra fingers and/or toes

insanity

Special Attention to Disabled: The disabled or deviant given "useful role in village life, that of musician."

Positive: The term deviant may or may not refer to persons with physical disabilities, but it does mention physical weakness of persons who were labeled deviant and who served as musicians." Thes people are allowed a place in their society. . "music is a vital necessity in Lupupa Ngye, and their musicians are at a premium." (318'

Negative: Although allowed a role and a niche, the deviant/disabled (?), some are ridiculed and "the constant butt of jokes about his physical weakness." (318)

Albinos considered to be witches and possibly malevolent'which could be negative. (151)(210)

General Infäticide/Senilcide: not practiced/at birth but practiced after birth. Yes, all malformed children

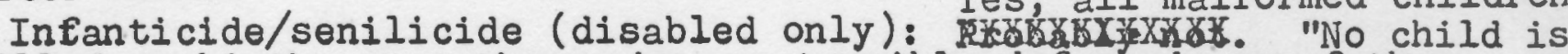
killed at birth, even those who are terribly deformed; on of the bantasha once saw a child born without a mouth, and it was allowed to die naturally."(208) "Whild no child is killed' at birth the practice o of killing children happened in past and may continue today." "Malformed children, Mongoloid, a dwarf, all have special terms. (209)

Comments: "Albinos are automatically considered to be witches."(151) "Because of their ability to capture men's spirits, and because of their malevolent abilities, witches are the subject of much discussion and action in Lupupa Ngye, and means of recognition of them is a frequent topic of conversation."(151)

Other "In cases of insanity, Mongoloidism, or other highly visible malfunction, the father requests permission to explain situation; notables

usually ask him to wait to see if condition improves, if not, father pe tions them again; child is killed.(209) "This kind of killing may exten to children of considerable age."(210) Midgets,

2) At one time midgets were probably killed and eaten. Moday. $\cdot$. Fre thought to be under the special protections of the chite dya Bala. $) 266$ 
Author: Crowley, Daniel J.

Disability

Reference: Aesthetic Value Group Data

Chøkwe

and Prolessionatism In AIt and personal letter.

FP4

HRAF Code: Card: Category:

Name of Culture Unit: Born in Katanga Chokolatwe, probably in the Altc Zambeze Province of Angola; moved to the Congo, Dilolo Territory* Location of group, society, culture: Two brothers moved, to join other
members of chokwe tribe Time Frame: January to August 1960.

Type of Society: Horticulturalists

(andicultural community

Number and/or Type of disabled persons: one crippled man; Kawina

Liwema, "he was a younger brother and sidekick of Sanjolombo, possibly

his maternal cousin rather than a biological brother since they use

Special Attention to Disabled:

Positive: Kawina Liwema lived in Sanjolombo's/villabe curve, every way a full.member of the community... (letter) Kawina Liwema was married and had two children

Negative: --

General Infanticide/Serilcide:

Infanticide/senilicide (disabled only):

Comments: * Sanjolombo is village chief and considered "dean of Katanga Chokwe songi (carvers) in the Dilolo territory."(236)

Pther * "The Chokwe region form the southern boundaries of the sculptur producing area of Africa stretching northwestward to the Gambia 
Dear Ms. Weiss,

Your project sounds excellent, something I'd long wished someone would do. Dr. Epple will have told you that we share more than anthropological training, i.e. polio.

As for bibliographic references, I can't help much. Have you had a chance to see if the Human Relations Area Files references disabiad people. Its beadquarters is at Yale Library, 6i maybe you could find out by phone. If they have it, jou'd get a long and useful list of bibliographical items.

As for Kawina Linema, he was a younger brother and sidekick of Sanjolombo, possibly his maternal cousin rather than biological brother since they use the term for both. He walked with both knees slightly bent and kegs stiff, possibly from an injury. He lived in Sanjolombo's village, since villages are family affairs in Zaire, and he carved, helped Sanjolombo in the fields, and was in every way a full member of the community even though he couldn't do stoop labor or hard harvesting. Remember women do the planting and weeding and most harvesting there. Chokwe like most Africans are very family-oriented and cooperative.

In that line, Liwema was able to do almost everything needed. More seriously disabled Africans do have special roles. In Islan, the blind are professional beggars led by a child, and it is the duty of believers and non-believers to give alms. The beggars clamor around and shout until you give them something, "baksheesh," and y.ou soon learn to carry plenty of local change. In Zaire the lepers all came on Saturdas morning after the market, some walking, some sliding on wheeled boards, some ringing warning bells, and each household was supposed to put money into a bowl they'd put in the yard. Quite a sight: In Trinidad, the blind also go around together, one's hand on another's shoulder, and beg at each market stall or street shop, and they get a few coins at every place to divide among them. It's bad luck not to contribute, and worse for business.

On a recent committee, I discovered that disabled people are almost never sent to Education Abroad programs, and of course getting around is vers difficult in European, African, and Asian cities, but the countryside is easier. One blind student found Ghanaians afraid of his seeing-eye dog. 
Deaf and learning-disabilities people have much more trouble both here and in the Third 'World, because people don't understand their problems. An mr girl about 12 in Zaire kept running awat from the nuns where the govt. had sent her, and since she always took off her clothes, everyone was afraid she'd get raped and pregnant. The amount of effort expended on keeping that girl out of trouble was impressive. Of course "the village idiot" is a standard character, the most poignant one being in the opera Boris Godounow.

Physically disabled men tend to.be pushed toward carving or arrow making or other technically-skilled jobs if their arms and hands are functioning. Similar women become weavers and basketmakers, but ceramics usually takes more agility. Music is the realm of the blind, not only Stevie Wonder and George Shearing, but also in many other societies such as calypsonians Blind Blake in Bahamas and King Radio in Trinidad.

I am very conscious of being treated differently in different countries. The British act like I'm sick and coming to England for treatment, and just hang over me, offering all kinds of unneeded help. The French act like I should know better and stay home, and actually give me shoves when I'm negotiating a high curb--really the worst! Most people are just intensely curious--I stop conversations dead when I enter a restaurant, though I hardly notice it anymore. I almost enjoy the ploys of those trying to find out what happened to me, what my private life is like, whether my kids were test tube babies, etc. In Aruba nobody would help me or push my wheelchair, "infra dig." Finally I found a Portuguese kid working in a kitchen and hired him. Aruba is Netherlands West Indies. In Brazilian Carnivals, the samba schools have amputees, wheelchair-bound "dancers," and blind members, and this year special seating for wheelchair cases. I was kissed by a minimum of 20,000 drunken Black ladies in a two-night period, a record even by my standards.

I'm afraid much of this is beside your point, but the subject certainly needs research. I think it'd get Foundation support too. So if you decide to go on, by all means count on my supnort. And even if you're in a wheelchair, do plan on doing fieldwork abroad. Being disabled is a kind of protection, since we obviously are trusting them not to hurt us, since we obviously can't run away.

Tell Dr. Epple it's nice to hear of him, and to know he is "mekin' style" as Chair, and even getting paid for it. Pearl and I were back in La Trinitee last March, and I had a few days there in November as well. This summer we're hoping to do Iceland, Greenland, Lapland, the Soviet Baltic, the trans-Siberian Railway, Outer Mongolia, and maybe Korea, but nothing definite yet, and maybe Carnival next Feb. in ex-Portuguese Goa south of Bombay. 
42 Walnut Street

Newport, Rhode Island 02840

June 7,1930

Dr. Daniel J. Crowley

Department of Anthropology

University of California, Davis

Davis, California 950616

Dear Dr. Crowley,

Dr. George Epple, Anthropology Depertment Chair, Rhode Island College, Providence, Rhode Island, is my advisor for an honors paper. He suggested that I write you because he thought that you might be able to direct me toward some bibliographical references on my topic. Also, he told me to remind you that you and he had worksed together in Trinidad.

The subject of my paper concerns persons with disabilities in the non-western world with the exception of the American Indian. As you know, persons with disabilties are accepted or not accepted in society. Dr. Epple and I have discussed how some persons occupy particular or specific niches in their society, that is, they have a special status and role while other societies assimilate persons with disabilities rather easily and make any necessary provisions to assist them.

My first objective is to compile a bibliography of all such references in Anthropological literature and then to see $i \hat{i}$ the data indicates that the presence of persons with disabilties tends to follow any particular pattern.

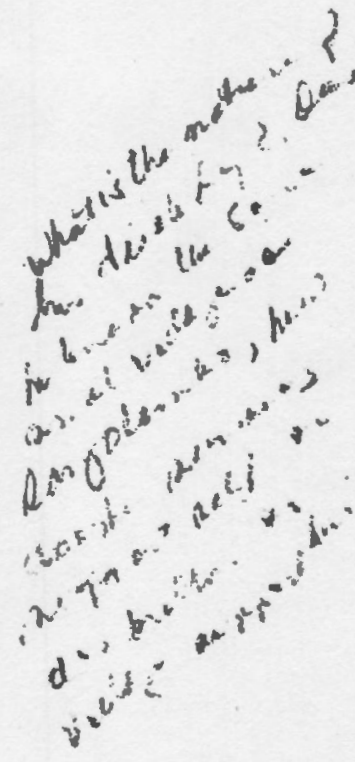

In an article you wrote, "Aesthetic Value and Professiona?ism in African Art: Three Cases from the Katanga Cho!swe," in The Traditional Artist in African Societies, edited by Warren L. d'Azevedo, you mention that "Sanjolomoo... and his crippled younger brother "Kawina Liwema decided to emigrate to the Congo." (p. 236) The reference reflects the presence of persons with disability in the society, and it infers acceptance, at least from his brotiner. If it would not be too inconvenient for you, would it be possible for you to give me a little more detail about Nawina Liwema, that is, how he survives and supports himself, or whether his family or the society does this for him? In addition, I was wondering if you have encountered any persons in your travels and research who are encouraged to be artists or musicians because of their disabilty, or anything else?

The subject of disabiltty is of interest to me because I Welik th-erutches/because of polio. and ths an inthropolozy major, it struck me that there is little or no research on the subject

I know that you are a very busy person, so please do not inconvenience yourself. It would be great to hear from you, though.

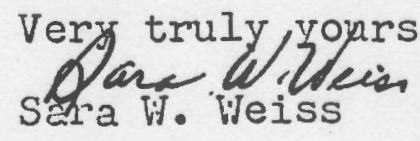


Author: Evans, Meryile

Reference: "In Botswana, Group Data

Recipes from Rochester" in New York Times, 8-15-54

HRAF Code: FVI Card: Category: no HRAF data available

Name of Culture Unit: safari lodge, Maun, Botswana

Location of group, society, culture: Maun, Botswana

Time Frame: August 1954.

Type of Society: Means of Subsistence: gardening and other sources

Number and/or Type of disabled persons: 1 blind man

Special Attention to Disabled:

Positive: Blind man worke as gardenerd in small safari lodge

Negative:

General Infäticide/Senilcide: unknown

Infanticide/senilicide (disabled only): unknown

Comments: Information indicates that a blind man was able to obtain employment and had developed skills as a gardener.

Other 


\section{Botsain \\ THE NEW YORK 'I'IMES, WEDNESDAY, AUGUS'I \\ Fr. \\ Botswana, Recipes From Rochester}

\section{BY MER YLE EVANS}

MAUN, Botswana $\mathrm{ACH}$ evening at 8 a rhythmic drum roll summons guests to dinner at San-ta-wani, a small safari lodge on the Okovanggo River in the middle of this south-central ican country. As the drums beat the candles are hted in the boma, a round, roofless enclosure ide of tightly woven reeds, high enough to disurage an inquisitive giraffe from peering over at - semicircle of tables arranged around a crackig fire.

When the diners have taken their seats under a nopy of brilliant stars, two waitresses of the Itawana tribe from a nearby village serve bowls steaming mushroom soup and pass thick slices fragrant freshy baked white and whole-wheat ead. At a sideboard across the boma, Bruceiller carves a succulent roast leg of lamb and "lis, "Come on up and bring your napkins - the Ites are hot!" There is mint sauce and gravy, an ortment of fresh vegetables - braised yams, uns, baked stuffed summer squash - and tossed lad with crisp lettuce and ripe tomatoes.

Other culinary surprises await guests at this de intful outpost in the wilderness, but the biggest rprise of all is the cook: a young American from chester. How did Nanette Ebersol, a soft-spoken tory-psychology major at the University of :hester come to San-ta-wani? And how did she $\eta$ to cope with such problems as marauding unkeys and temperamental gas generators? ace Corps training is the answer.

"Ever-since high school," the 25-year-old Miss versol explained, "I had wanted to join the corps, I applied and was accepted during my senior ar at college." Assigned to a school in the mining wn of Lobatsi, Botswana, she taught mathemat and science to 55 students aged 12 to 23 . Virtu ly no.scientific equipment was available, only a ackboard, so she made do with ingenuity and perverence and was awarded a coveted commendaon in December 1983, at the end of the two-year ogram.

During a Christmas vacation, when Miss Eberl's parents, two sisters and brother came for a isit, the family spent a week in Botswana's vast, ispoiled wildlife reserves. Their photographic sain was arranged by Gametrackers International, consortium of local companies and the Botswana - Jvernment, which operates four camps in remote $r$ as. Miss Ebersol loved the atmosphere at the IIIps, so, after completing her stint in the Peace oriss, she applied to Gametrackers for a job and - as offered that of caterer-housekeeper at San-taani. "I had never had the least interest in cookIg," she acknowledges, "but I came from a imily jo excellent cooks." Soon letters were flying ack and forth between Botswana and Rochester it th requests for favorite recipes and replies from ur mother, Rita Ebersol.

There was also on-the-spot assistance from Wit ess, a native of the area, who, though blind since irth, tends a flourishing vegetable garden behind te kitchen. Walking barefoot, Witness counts the umber of steps between the rows of cucumbers, bgplants, cahbages and beans he has planted. He an point out each variety, and by gently touching le tops of the plants he knows when to pull up carts and onions. His garden, protected by a strong nce, from, the hippopotamuses that ilumber isugh : San-ta-wand at night, supplies all the

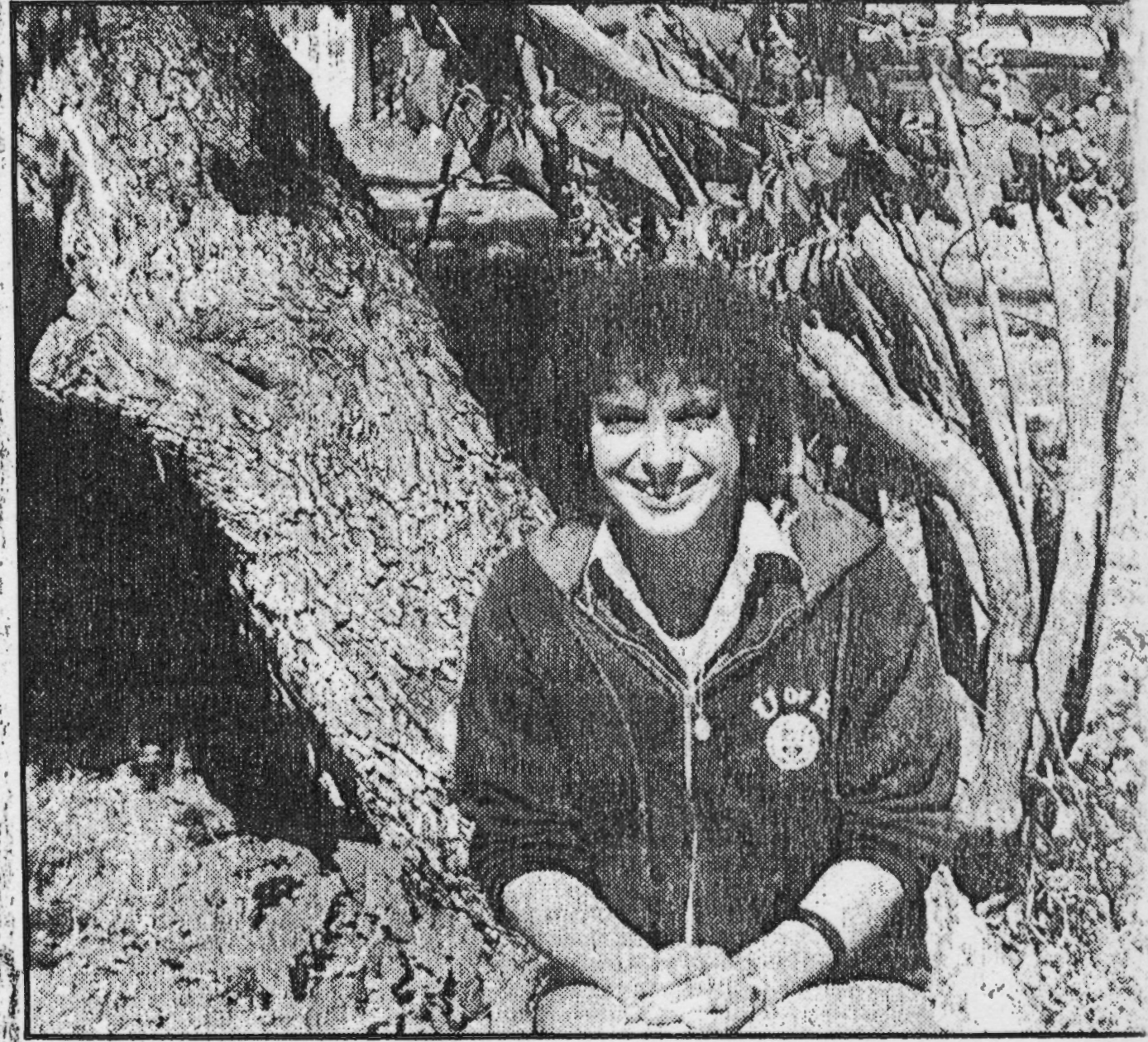

Nanette Ebersol is caterer-housekeeper at an African game lodge.

Culinary surprises prepared deep in

\section{Africa by a former Peace Corps aide.}

Gametracker camps with fresh produce.

Like other perishables, including eggs and the Stilton, Camembert and cheddar servea for dessert at lunch, the vegetables are transported (when there is space) in the single-engine Cessna that flies guests to the camps. Haphazard airborne deliveries are a minor inconvenience for Miss Ebersol. The havoc wrought by hungry hyenas is more of an annoyance. Each dawn she checks to see if the night prowlers liave attacked the garb cans or chewed up the uphulstery in the lour Then the stove is lighted for wake-up tea and col sent to the cottages at 7.

Half an hour later a dozen guests and staff mo bers with luuge appetites plow through a break of papaya, cold cereal and hot porridge, coun sausage, thick slices of bacon, scrambled and, perhaps, corn fritters or broiled tomat Then everyone is off for the morning game dr bouncing around the bush in Land-Rovers or dling canoes through the winding Okovan waterways, while the caterer-housekeeper st behind to supervise the staff, plan meals and cl supplies. Culinary. staples are brought by tit from Maun, a 70-mile trip over ruugh dirt roads.

Some fresh chickens arrive, and when the gu return at 1 P.M. there is chicken stew with and peppers, shredued carrot salad and coles tossed with pineapple cubes. There is also a $\mathrm{g}$ deal of aninuated table conversation - a T drawl mixing with German and New York ac and clipped New Zealand Englisl - as the g discusses the herds of zebra, mating lions triches and crocodiles seen lazing in the sun.

After lunch everyone - even the staif nap. But by teatime Miss Ebersol has bak batch of ralsin cookies. They disappear as qui at Saul-ta-wani as they would in the family kit in Kochester 
Author: Marshall, Lorna Disability Reference: The !Kung of Group Data

HRAF Code: FX10 Card:

Category:

Name of Culture Unit: The Kung of !Nyae Nyae, Kalahari Desert, Africa

Location of group, society, culture: Kalahari Desert, Africa, Nyae Ny area.

Time Frame: Contemporary; field trips: 1951,1952,1953,1955,1959,1961

Type of Society: Means of Subsistence: Hunting and gathering

Number and/or Type of disabled persons: 1) childiess old blind woman, Band 9, N/aoka; Di//khao and an old great-grandmother... only gathered occasionally (aged infirm?) (97) 2) Short Qui who lost his leg when he was bitten by a puff adder. $\left.\left(142: 7^{n}\right) ; 3\right)$ ! Kham crippled by bone disease and LamefGao another cripple;(186-187);

Special Attention to Disabled: When person becomes dependent. . His firewood woulbe. brought; meat given, someone would gather for him. "(97)

Positive: "When a person becomes genuinely dependent because of age or disability or.is. temporarily sick, he is provided for by close relatives... The foremost responsibility belongs to relatives... spouses, par ents, and offspring, parents-in-law and son- or daughter-in-law, and si lings in that order." (98) Mothers carry sick or lame children for days. even years. (288) Disabled accepted by band. (187) Pisflpled given meat.

Negative: Infanticide and possibily senilicide. Ridicule of lame and crippled persons. (288) Kung children mimic "peculiarities of posture and movement." (315) They do not help the crippled person to get up ificandiuger-they fall. (288)*

*This may be Marshall's own interpretation and biak; even in Western society, many disabled prefer to reject assistance unless absolutely necessary.

General Infanticide/Senilcide: The Kung practice infanticide when there would be two infants to nurse at the same time, possibly senilicid (Ibofzuticide/senilicide (disabled only): The Kung practice genenal infanticide so 1t 'Is likely that tabnorial infants are not allowed to live because they! could not be expected to be strong enough to keep up with the band; the Kung nurse their infants until 3-4 years of age to provide them with strong legs and base their practice of infanticide on the necessity of providing mother's milk for their babies. (188:2660) Comments: Family and kinship ties are the imost important factor for the !Kung, especially for the disabled; without families the disabled are more vulnerable, but they are given meat when unable to hunt; appeared to be welcome visitors; (187) and have found ways of making themselves useful to the band. (187).

other 
Author: Thomas, Elizabeth M. Disability

Reference: The Harmiess Group Data

people

HRAF Code: FX10 Card: Category:

Name of Culture Unit: Bushmen--Gautscha Pan

Location of group, society, culture: Southwest Africa, Gautscha Pan in N.W. corner, Ralahari Desert.

Time Frame: 1958-1959

Type of Society: Means of Subsistence: Hunterssand gatherers.

Number and/or Type of disabled persons: Lame boy mentioned; man who had lost an eye; Short $\mathrm{KWi}$ who had lost part of his leg when bitten by a puiff adder. $(197,229,231,238,239)$ Tu's brother, the lame boy. (197

Sperial Attention to Disabled: Family, near relatives, band (to some extent care for disabled and provide for them. Positive: Bushmen do not "(239gndon cripples or people who are old or
sick or who cannot.travel."

Negative: Infanticide. If unable to hunt, not eligible to inherit headmanship. (197) In Bushman practice a boy does not become a man until he has shot his first animal and killed it; then he is initiated by being scarified with a paste made from the animal's meat (in this case, a Kudo), and becomes a man. Thus, unless the kill takes place, he is not looked on an adult.

Negative attitude; depressed about anyone who becomes disabled. (246) Disabled shunned/avoided by their "remote" kin. (246)

General Infanticide/Senilcide: General infanticide (163) Senilicide not mentioned.

Infanticide/senilicide (disabled only): Infantioide of deformed infants expected (163).

\section{Comments:}

Other 
Author: 2: Masters,

Disability

Middle East

Reference :

Group Data

MAII

HRAF Code: MA:Il Card: 034 Category: 735

Name of Culture Unit: Kurd, Rowanduz

Location of group, society, culture: Rowanduz

Time Frame: c. 1950's

Type of Society: Means of Subsistence: Industrial, heterogeneous population, administrative town, eoonomic specialties, yerieffsošcial

Number and/or Type of disabled persons: Numbers not mentioned.

Types: Demented persons who appear to be harmless and deformed infants.

Spexial Attention to Disabled: Eccentric members of community allowed to become darwishes, a religious mendicant $(177)$

1)

Positive: ". . abberrant members of any community whose eccentrici ties have been adjudged harmless to others. - are absorbed into the darwish movement, because. . it offers social status of an extraordin ary sort, and. - a channelled expression for personal peculiarities which might otherwise prove dangerous."(321) Most darwishes become sna

2) Deformed infants loved and kept at home.(255) charmers or swallow large pebbles for alms

3). Alms and charity to beggars/menuicants/other disabled persons part of Moslem religion; Muslims are expected to give part of earning, income to the poor in alms. (303). Wealthy families sometimes suppor, "slightly demented" persons and their families. (329)

General Infänticide/Senilcide: Evidently not.

Infanticide/senilicide (disabled only): "Deformed infants, if they survive, are kept within the "house and their parents 'thank God for them" just as with other normal children," which leads one to believe that infanticide is not practiced. (255)

Comments:

Other 
Author: 4 :Hansen

$$
\begin{aligned}
& \text { Disability } \\
& \text { ool-Gurdeup Data }
\end{aligned}
$$

Reference:

$037-\cdots-\cdots 4$ (infanticide)

HRAF Code: IMA 11 Card: 034 Category: 735

Name of Culture Unit: Kurds

Location of group, society, culture: "yillage of Top awa '(148)

to the West $8 \mathrm{f}$ Rowanduz and in "Sulaimani"(148)

Time Frame: 1950's

Type of Society: Means of Subsistence: not known

Number and/or Type of disabled persons: "Two beggars, the younger of whom being blind, was led by his hand being placed on the shoulder of the other, both had sugar and flour poured into their begging bags, iv invalid women. . on crutches. Deformed feebleminded girl deposited at "entrance to the mosque" with a bowl between her deformed hands.

Special Attention to Disabled: Muslim practice of giving alms to begge

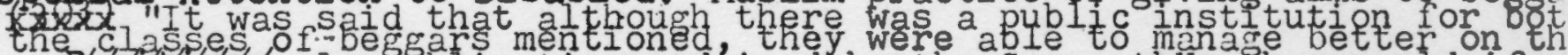
Bostity $y^{\circ}$ alms obligation ordained by the Coran than they would if they entered the.institution. . ." 1486149$)$

Begging for alms, an acceptable social institution, and a method of social responsibility to the poor and disabled. Keeps the disbbled in sight, rather than hidden, but are objects of pity.

Negative: Almsgiving not rehabilitative; disabled objects of pity rather than seen as individuals with specific needs.

General Infäticide/Senilcide: (Evidently not; see Masters:255) No birth control permitted; many births; many natural abortions. Infanticide/senilicide (disabled only): See above

Comments: Hansen describes the giving of alms to the disabled sick and poor at the "aristocratic village home at Top ara and at the entrance to the mosque in Sulaimani and in the street there. 


$\begin{array}{lll}\text { Author: Sweet, Louise } & \text { Disability } & \text { Middle East } \\ \text { Reference: Tell Togaan, } & \text { Croup Data } & \text { Syria } \\ \text { A Syrian Village } & \text { Tell Toqaan } \\ \text { HRAF Code: MDL Card: } & \text { Category: } & \text { MDI } \\ \text { Name of Culture Unit: Tell Toqaan } & \end{array}$

Location of group, society, culture: See attached map.

Time Frame: c. 1950's

Type of Society: Means of Subsistence: Pastoralists and

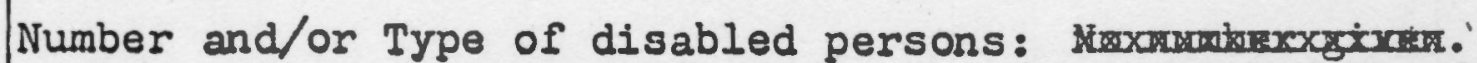

Types: "Several members of one family showed marked dwarfism or spinal curvature. One boy from another family suffered from a deformed hip,

so he was only able to hobble with a stick. . . There was one small

child. . who was unable to sit up and was quite unresponsive."* (This

is out of a population of 319 permanent residents).(23-24)

Spexial Attention to Disabled:

Positive: The little boy who used a stick for a crutch "crawled mos of the time or was carried about the village by his older cousins or by playmates which indicates that he was included in village activities an not left to himself.

Negative: "The "possessed" woman was "tolerated amicably," but the "slept wherever she found shelter. . . begged or scavenged enough to keep herself alive."(23)

\section{General Infanticide/Senilcide:}

Infanticide/senilicide (disabled only):

Comments: *Another boy was hunchbacked." One woman in the village, decribed as majnuunii, "possessed" was irrational." (23)

Other Religious "rituals" are resorted to in times of illness and a great deal of faith is placed in the efforts of "curing shayxs" $(218-219)$ 
Author 21:erulliz-

Reference:

Disability

Group Data
Middle East Somali

$\mathrm{MO} 4$

HRAF Code: MO4 Card: 074 Category: 735, 429,681

Name of Culture Unit: Migiurtini, a Somali group or tribe

Location of group, society, culture:

Time Frame: (1916) 1959

Type of Society: Means of Subsistence: Pastoralists, camel camps, nomadic hamlet or important elder residents live in towns and movebet

Number and/or Type of disabled persons: Numbers not mentioned. Types: abnormal births and demented persons.

27:Cerulli -blind, cut off nose, one hand or foot ( 94 cont) reparation for the fingers

Spexial Attention to Disabled:

Positive: "If a Migiurtino, because of mental infirmity, is unable tc

1) administer his property, . . paternal relatives assume responsibility. to assume the administration of incapacitated man's property." No mention was made of incapacitated females.

2) ". . only have the obligation to feed the incapacitated man."

3)*

If No relatives, the 'gems' adiume responsibility.

Since care is limited to administration of property and only providing food for the mentally disabled, their other needs are not addressed. The family andisociety see their function as purely the individual concerned and to care for economic resources; not rehabilitative.

*life sustaining; it is not even custodial.

General specicl (other than disabled)Yes

and low-caste man is kilied at birth." $(27)$ No senilicide.

Infanticide/senilicide (disabled only): "In fact-abnormal births were killed at once; thrown into the sea by coastal populations, burien alive by inland peoples."

abnormal children killed at birth.(27)

4)*

Comments: If an individual is disabled by another then compensations are paid, "If, because of the blow, he has blinded an eye, 50 she-camels; "If because of a wound, he' has cut off a hand or a foot, 50 she-camels. (27: Cerulli $/ 94$ cont/ Means of social insurance -reparation for ilsability

Other 
Author: Lewis

18: Lewis

Reference:
Disability

Group Data
Middle East

Somali

$\mathrm{MO} 4$

HRAF Code: $\mathrm{MO}_{4}$ Card: Category: 829-854

Name of Culture Unit: Somali (formerly Berbers)

Location of group, society, culture: See map

Time Frame: (no date) 1955

Type of Society: Means of Subsistence: Cattle grazing, animal husbanc ry, agriculture depending on region (see map and description)*

Number and/or Typo of disabled persons: Not given

Types: 1) abnormal births--see infanticide; 2) respect for aged/woul include aged infirm; 3) mentions "mundanely helpless" 4) prevalence of opthalmia(which can lead to blindness) in native population." (112, 113 $181 ; .197)$.

Spexial Attention to Disabled: "Only rarely is a wounded person or crippled person seen mounted on a camel."(62)

Positive: 1) aged infirm probably cared for since the aged are honor in Somalia society.(197)

2) "Poverty and weakness in general are blessed in the sense that God is believed to accord special protection and help to the mundanely help less." (112)

3) almsgivingi institutionalized-informal method of caring for depende Negative: practice infanticide in event of abnormal birth.

General Infänticide/Serilcide:

Infanticide/senilicide (disabled only): Yes. (Lewis, Cerulli) Infanticide considered rare by: "Drake, Paulitschke)

*Influential elders/sheikhs spend much of their time in the towns, hold town pooperty but"holds ties with pastoral agnatic kinsmen."(93)

Comments: There is a conflict or contradiction heze: Lewis speaks of how "poverty and weakness" are blessed, but on the other hand abnormal infants are thrown into the sea or buried alive. Cerruli studied the $\mathrm{Sab}$ groups (outcastes) who may have differed from other Somalies in the practice of infanticide; however Lewis cited it too.

pther "To refuse alms and kindness to the unprotectdd and helpless is un wise for two reasons. Those who are poor and defenceless are considere to enjoy the special protections of God. . Acts of kindness to them ar rewarded; acts of aggression punished. . .2) The power of casting a spell upon someone who refuses alms is generally described as gabrro an and the poor are said to possess the evil-eye ('awri) which is associated with covetousness." Thus to the impoverished, and in a sense the underpriviliged, mystical power is attributed."(263)

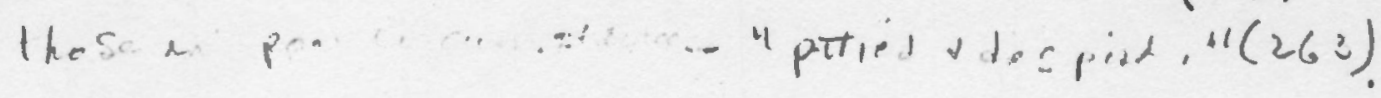


Author: Drake

Disability

Reference :

HRAF Code: $\mathrm{MO}_{4}$ Card: Category: 847 (infanticide)

Name of Culture Unit: Somali

Logation of group society culture: "inhabit area of approx. 1,000 t 5oundary, Indian ocean; west and southwest boundary/Ethiopla, Kenya. East

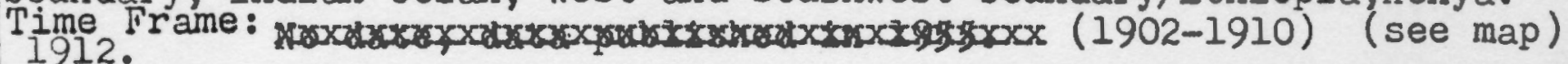

Type of Society: Means of Subsistence: Cattle-grazing, animal hushandry 3 tittle agriculture in northern regionsiosguthern territories Number and or Type of disabled persons: neither mentioned. see infanticide

Special Attention to Disabled: "old age is honored"(147) which leads to assumption that aged infirm are cared for.

Positive:

Negative: Occasional practice of infanticide.

General Infanticide/Senilcide: Author claims infanticide rare, only knew of one case in years he lived among Somali." (147)

Infanticide/senilicide (disabled only): Infanticide,poobably. (see Paulitschke (1880) HRAF Mo4 Somali; category: 847) and Lewis, Cerulli. Cerulli dealt with Sab tribes, "who are markedly different - . from the rest of the population." (Orientation--MO4--10(categors

Other 
Author: Stenning, Derrick J. Disability

MSII

Reference: Group Data

Middle East

West Bornu

Province

HRAF Code: MSIl Card: Category:

Northern Reg

Name of Culture Unit: Wodaabe, Fulani

Nigeria

Location of group, society, culture: Western Borna: Province, Norther Region, Nigeria

Time Frame: c. 1950's

Type of Society: Means of Subsistence: Pastoral, Stenning refers to

PP.6-7. Them as Savannah Nomads and semi-sedentary; combine farming/stoshrfasic

Number and/or Type of disabled persons: No number mentioned. Types: deformed infants, people who are crippled, congenitally infirm, congenitally insane.

Impotent males.are referred to as "a bent, withered, or maimed one." (a man's homestead may not be formed until he has begotten a child." (163)

Special Attention to Disabled: The chronically sick, permanently deformed do not fit well into the pastoral life, seasonal movements.

Positive: Sick, deformedpersons arent to sedentary relatives or friends "unless they can'get around on crutches and move long distances seated on a donkey." (168) Sick children, or deformed ones. . . are given no preferential treatment and may die of what amounts to neglect." (168) However, Wodaabe Fulani had a system to help the poor/unfortunate that hadbeen deve'loped prior to Islam/lakat (62)

Negative: Sick or deformed children. . are given no preferential treatment and may die of what amounts to neglect." (168)

"If the congenitally infirm or deformed survive the rigours of a child hood in Pastoral Fulani camps, they are not betrothed since their condition carries with it a sort of moral stigma. This is particulary tr of those who are in some degree congenitally insane."(126) Social conventions are not applicable to them, they are not betrothed or married or allotted cattle."(126)

General Infäticide/Senilcide: not mentioned

Infanticide/senilicide (disabled only): If not in theory, then in practice.

Comments: By not giving sick or deformed infants/special.treatment the Wodaabe "recognize the operation of this natural selection when they state that if a child reaches the age of five, it will attain maturity. (168)

Other "The harshness of the conditions under which Pastoral Fulani live

1) is accompanied by an attitude which allows little sympathy for the congenitally deformed or for the sick, be they adult or immature."(16" Stenning mentions "Zakat," the charitable fund of Islam for the poor and destitute, but he does not mention it in relation to the disabled, or are they not included? ( 61-62) 
Author: Tremearne, A. J.N. Disability

Middle East

Reference: Hausa Superstitiong froup Data

IMS12

and Customs, in Introduction to the Folk-Lore and the Folk

Hausa

HRAF Code: IIS12 Card: Category:

Name of Culture Unit: Hausa

Location of group, society, culture:"Hausa States forming the greater part of what is now Northerm Nigeried Frengh possessions to West, and Time Frame: lst ed. 1913; ;

Type of Society: Means of Subsistence: "Primarily agricultural, with shifting cultivation " following a crgp rotation, use of animal manure an

Number and or type of disabled persons: numbers not cited.

Types: Blind, idiots, deformed children, leper, deafness, mutilated persons w/one hand and foot, albinos, half-beings, deaf-mute, paralysis dwarf, insanity, cripple,

\section{Sperial Attention to Disabled:}

disabled persons in Hausalar

Positive: There must be a care system for in kaddue "Although "The

is carried does not realize that the town is far off. '" (62) Bori dancing originally treatment for the insane "the idea being that those who were really mad would be thereby less likely to commit acts of violence. . funatics are never shut up amongst pagan people but regarc as people specailly set aaprt by the gods. " "(1469*

Negative: Punishment for theft, cutting off of a hand (left hand lst. or foot. (457)

Author cites games and riddles: "The Hausa is an inveterate gambler. . loaded cowries are not unknown, for it is not only a blind man who cheat (58) "The blind man cannot see our bitter grapes, although 'Since he lac eyes he says that eyes smeli:" (60)

\section{General Infänticide/Senilcide:}

Infanticide/senilicide (disabled only): "albinos once killed and eaten by an army before setting off for war". . . "faırly widespread prac tice of throwing idiots and deformed children into the river (Zaria prov ince)."(93) (see stories $70 \times x \times 173$ ).

Comments: "Blindness is very common in Hausaland so is lameness, the fe often being eaten away by leprosy, or through the destruction of the toe. by the 'jiggers." (512)

1)

*

Other The author describes the "Bori" dance which is "absolutely forbida now."(530) In the "Bori" there are disabled characters: "(12) Bebe-Deaf Mute...(34) Inna--Stuttering. . . (40) Kuruma--Deafness, (41) Iuturu Leper" have a well-developed sign language (55-57) which is used to commu

icate with deaf-mutes. (49)

*Bori--"is self-induced hysteria. During possession by the spirit\$, the patients imitate certain persons or animals or iill-trgat themselves. The spririt is usualy expelled by sneezing. "frontispie"ce 
¡uthor:L: Wurdock

Reference:

Group Data
Fl Africa

Ml Middle East

MS12 Hausa

\section{HRAF Code:MSI2 Card: Category:}

Name of Culture Unit: Hausa (see attached identification)

Location of group, society, cuiture: "inhabitants of former states of Bora,. Raura, Gobir, Kano, Katsena, Kebbi, Rano, Zamfara, and Zaria

Time Frame: (No date) 1958

Type of Society: Means of Subsistence: agricultural, with shifting cultivation, fallowing, crop rotation, use of animal manure, irrigation Number and/or Type of disabled persons:

Special Attention to Disabled:

Positive:

Negative:

General Infänticide/Senilcide:

Infanticide/senilicide (disabled only):

comments :

Other 


\begin{abstract}
Author: 2: Greenberg
Disability

Reference:

Group Data

MiddleEast

Hausa

MS12

HRAF Code: MS12 Card: Category: 753

Name of Culture Unit: Hausa

Location of group, society, culture: See description/location attach.

Time Frame: (1938-39) 1946

Type of Society: Means of Subsistence: intensive

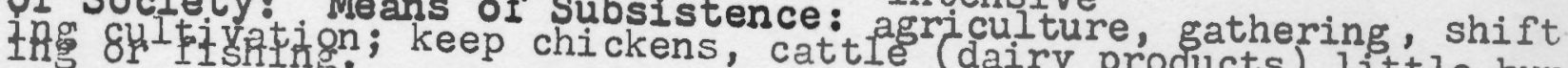

Number and/or Type of disabled persons: No number given."
Type: lameness, loss of soul
\end{abstract}

Spexial Attention to Disabled:

Positive: ...

Negative:

General Infänticide/Senilcide:

Infanticide/senilicide (disabled only):

Comments: Spirits may be "malevolent or good" and can cause sickness there is a belief in witchcraft.

One spirit, "Gurgu, who is/was a lame hunter and lives in the forest,
causes lameness. (, 34 )

\title{
pther
}


Autror: 10: Hassan ic Shuaibu Disability Middle East Reference: Group Data

HRAF Code: MS12 Card: 073 Category: 8Th

Hausa

Name of Culture Unit: Hausa, Abuja

Location of group, society, culture:

Time Frame: (ca. 1940) 1952

Type of Society: Means of Subsistence: agriculture, gathering Number and/or Type of disabled persons: numbers not given no:-disabled

Sperial Attention to Disabled:

Positive:

Negative:

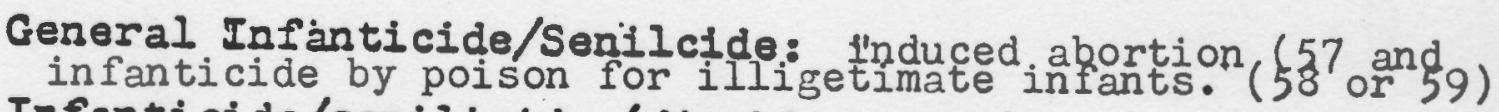
Infanticide/senilicide (disabled only):

comments:

pther 
Author: 3: Smith

Reference:

HRAF Code: MS12 Card 007, 073

Name of Culture Unit: Hausa

Location of group, society, culture: see attached identification and

Time Frame: (No date) 1958 location

Type of Society: Means of Subsistence: agricultural, gathering (15-1

Number and/or Type of disabled persons: no number mentioned.

Types: madness, aged infirm $(53,155)$

\section{Sperial Attention to Disabled:}

Positive: "Hausa fathers own property until death"which ensures that they are cared for; women not mentioned. (53)

People who go mad are cared for; sometimes they are "bound" when they are violent or aggressive, but they are given "medicine" and returned to society if, their condition improves.

\section{Negative:}

General Infanticide/Senilcide: Infanticide not mentioned. Infanticide/senilicide (disabled only):

Comments: It is believed that men go mad if they fail "to give alms to the spirits, a bull and chickens. - "( 155 )

pther 
Author: Ames, David W.

Warren L. The Traditional Artist in African Societies

HRAF Code:

Card:

Category:

i. MSl2

Name of Culture Unit: Warsan Location of group, society, culture: settled in Hause communities Time Frame: Field work - 1963 and 1964

Type of Society: Means of Subsistence: agriculture--basic economy(12 Iria City/larger towns - little farming; specialists in eco. pursuits. Number and/or Type of disabled persons: reference to "blind beggars" who "are also heard chanting in homes and markets. - "(133) The autho lists them as "non-professional musicians."(133)

Spexial Attention to Disabled: Begging institutionalized. Positive: Begging a method of social care of dependent persons.

Negative:

General Infäticide/Senilcide: Infanticide/senilicide (disabled only):

Comments :

Other 


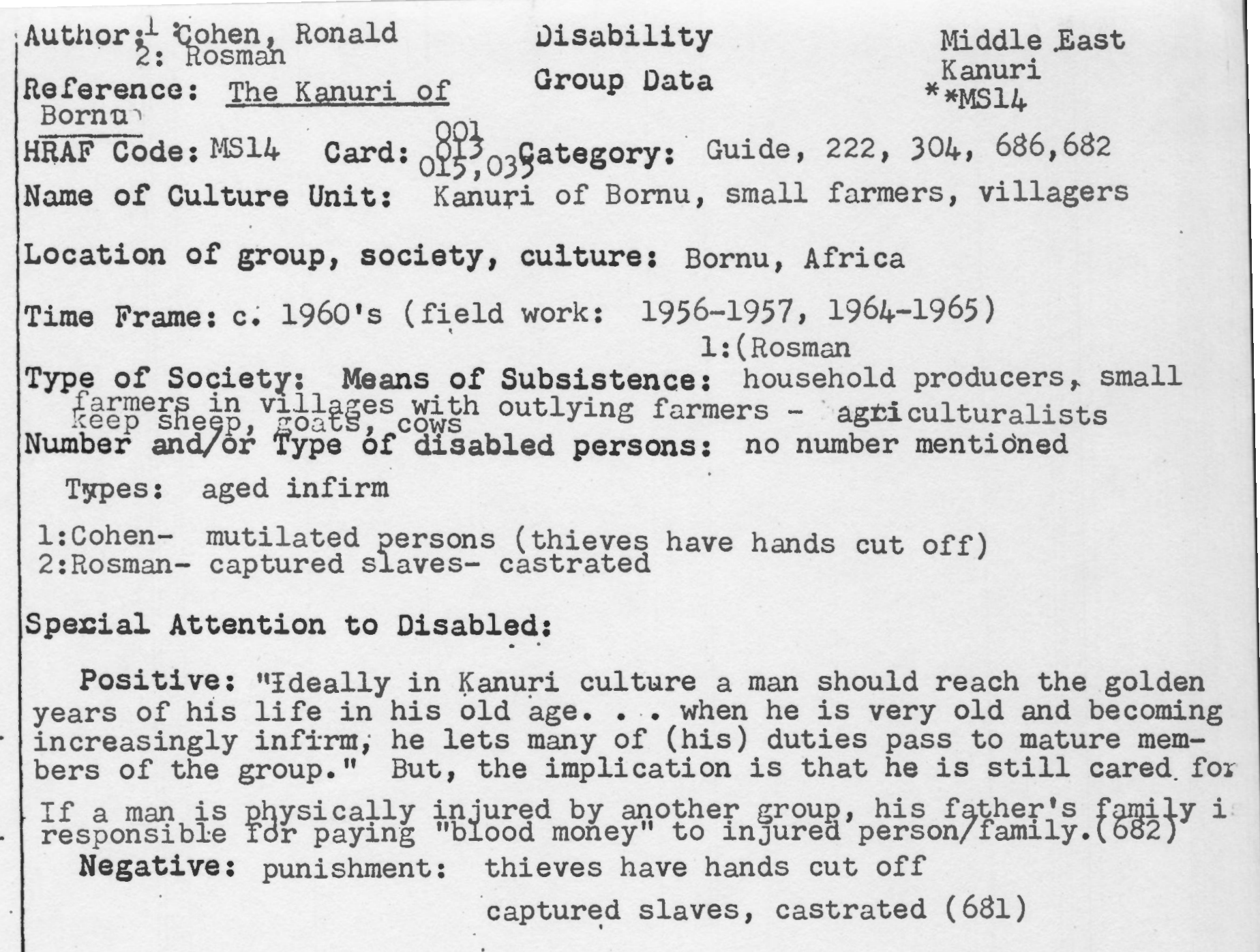


HRAF Code: MS14 Card: 036 Category: 732, 563, 783,621,622, Name of Culture Unit: Kanuri

Location of group, society, culture: Town of Geidam, adm. center of Geidam District, Bornu

Time Frame: (1956-1957) 1966

Type of Society: Means of Subsistence: Town- several economic specialties: tradesmen; ropemakers(blind), tanners/dyers/craftsmen, beggar Number and/or Type of disabled persons: numbers not mentioned.

Type: blind

\section{Spexial Attention to Disabled:}

Positive: "The blind specialize in making rope, and live as an organized sub-community in their quarter. They have their own head, callc the Kaigama, because he is to the Shehu of the blind, who lives in Maiduguri, as the-real Kaigama is to the Shehu of Bornu."(129)

Negative:

General Infänticide/Senilcide: not mentioned Infanticide/senilicide (disabled only): not mentioned

\section{Comments :}

Other 
Author: Minor, Horace

Reference: The Primitive

City of Timbuctoo

HRAF Code: Card:

Name of Culture Unit:

Disability

NLUULe van

Africa

Mali

Timbuctoo

MS23

Location of group, society, culture: Mali, Africa

Time Frame:

Type of Society: Means of Subsistence: Urban

Number and/or Type of disabled persons: No numbers given.

Type: blind mendicants

Spexial Attention to Disabled:

Positive: 'Almsgivers share their' wealth with the poor at "The end of Haome and the beginning of Ferme, ...occasion for feasting, dancing, and gaiety. . ." so the poor can celebrate too. Blind beggars position themselves within a tomb and the donors give alms through a small opentigg; the beggars hand out sand which the donor sprinkles on his body. (133)

Negative: "Blindness falls in a special category of belief concerning the baraka of the blind and concepts concerning the evil eye. The affliction may simply be considered the will of Allah."(220)

General Infänticide/Senilcide:

Infanticide/senilicide (disabled only):

Comments: Explanations for blindness: Evil eye; will of Allah, or that if a pregnant woman"sees certain objects or they are left in her presence for several days, 'so they may pass out of her heart.' Deformations are attributed to the aleone, to the breaking of Kabi restrictions, or to natural causes such as a mother's fall." (र20)

pther 


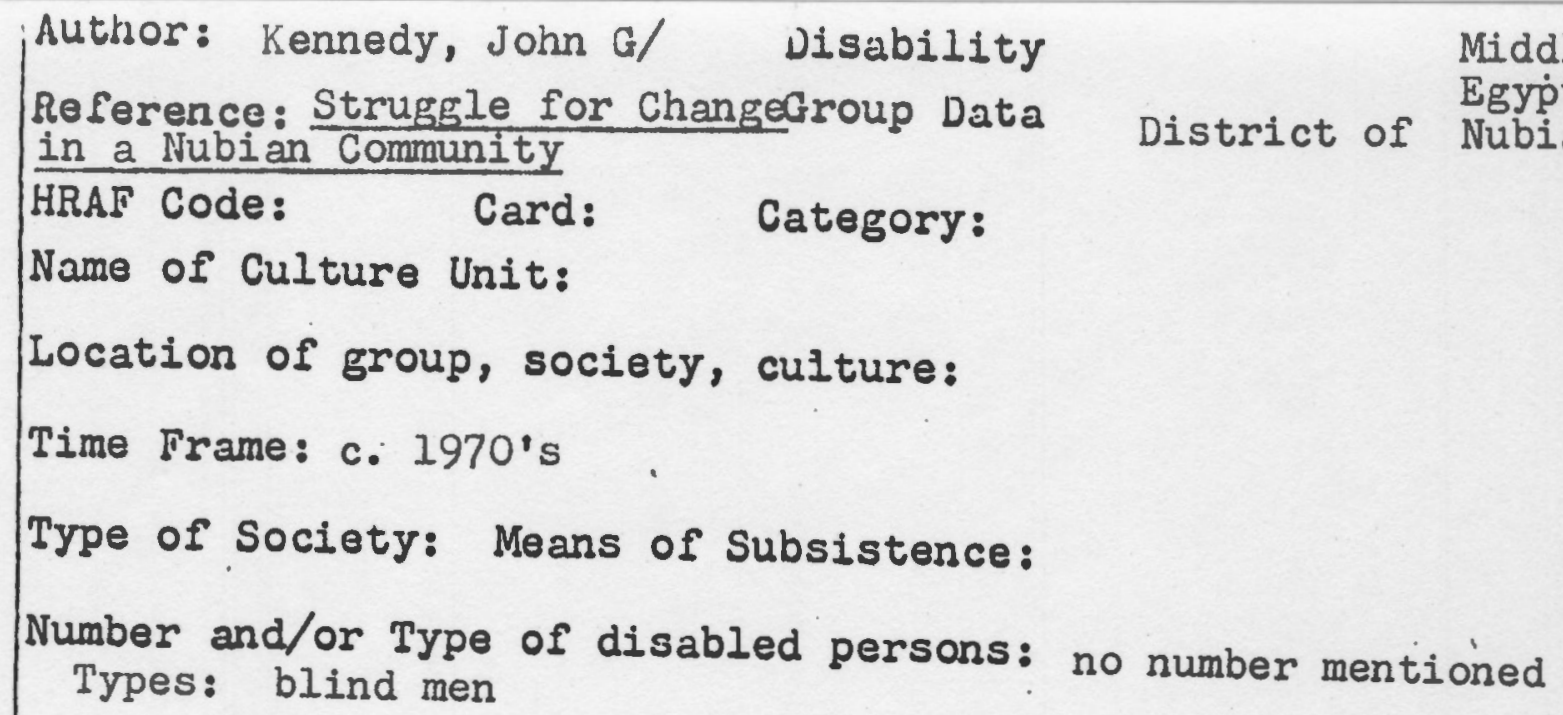

Negative:

General Infänticide/Senilcide: Infanticide/senilicide (disabled only):

Comments:

\section{Other}


Author: 1: Jinness

Reference: Categorj: $104 f_{4} 040$ Group Data

HRAF Code: ND8 Card:/\% Category: 171, 752, 166, 845, 847,753

Name of Culture Unit: Copper Eskimo; relatively unacculturated until about 1910

Location of group, society, culture: Coronation Gulf nrea of the Canadian Northwest

Time Frame: (1913-1916) 1922

Type of Society: Means of Subsistence: 'Caribou, seal, and fish were their mainstays"

Number and/or Type of disabled persons: No specific numbers mentionec

Types: limbs were amputated if frozen.

defective child

\section{Special Attention to Disabled:}

Positive: Tried to cure, help them according to their limited medical knowledge.

Negative: "One woman exposed a child about three years old; it as be witched, she said, and only a burden to her. The child was probably defective, for, though it had grown.in size, it had not developed properly and could neither stand alone or walk."

General Infanticide/Senilcide: Yes. "If twins are born one at least must be killed or given away; boys are given preference to live.

Infanticide/senilicide (disabled only):

Comments: The climate and conditions are so harsh that "an Eskimo woman could not possibly rear both children at the same time." Some times someone in the tribe adopts the unwanted infant or child.

Explanation of disability: ". . death, accidents, and sickness the Eskimo knows only one cause, the maligmant activities of evil spirits bther or of the shades of the dead."

According to author The People of the Twilight, the Eskimos were killed off by exposure to white men's diseases such as smallpox; some of those persons probably did not die from the disease but were left disabled. 
Author 8 S

Reference:

HRAF Code:NDơ Card: 072 Category: 731,736,

Name of Culture Unit: Copper Eskimo

Location of group, society, culture: Coronation Gulf area of the Canadian Northwest

Time Frame: (1908-1912), 1914

Type of Society: Means of Subsistence: "Caribou, seal, and fish

Number and/or Type of disabled persons: Numbers not mentioned but examples given: 2 blind men; Avranna, Clouston Bay

blind man, Prince Albert village

Special Attention to Disabled:

Positive: "Care of Infirm. One man of about forty-five, Avranna, is totally blind [297]. and has been 'for a long time.' He seems tenderly card for and goes walking about outside with his cane, guided by the shouts of grown people or children warning him of obstacles and telling him where to go."(category: 736)

Negative: Exposing of children and abandonment of aged, "it may be considered a direct result of the scarcity of food, for it is found rarely or not all in such prosperous, well-fed communites as those of Cape Smythe (Point Barrow). and the McKenzie Delta, while among all inlanders it is so common as to scarcely induce comment."(category:731)

General Infanticide/Senilcide: Yes, probably depends on location anc scarcity of food and harshness of environment.

Infanticide/senilicide (disabled only):

Comments :

Other 
Author: Becker, Howard

Disability

North America

Reference: Societies Around

Group Data

East Greenland the World

\section{HRAF Code: Card: Category:}

Amasselik Eskimos

Name of Culture Unit: Ammasselik Eskimos

Location of group, society, culture: Greenland--E. Greenland coast ex. tending from 65 th to 68 th degree of latitude around Sermilik, Ammasse

Time Frame: c. be50dsx 1930's

Type of Society: Means of Subsistence: Nomadic; furahing, hunting, (look to the sea for food, clthes, shelter)gathering in season

Number and/or Type of disabled persons: numbers not mentioned disabled infants, adults, or aged infirm

Special Attention to Disabled: The society preticticed invalidicide, senilicide and suicide (105) Positive:

Negative: Because of environmental conditions, the Eskimos practice or practiced invalidicide, senilicide, and suicide. ( 705 )

General Infanticide/Senilcide: Yes, prof female infanticide moxe not

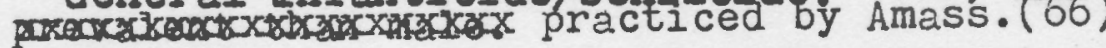

Infanticide/senilicide (disabled only): Yes. This is based on "principle that only those may survive who are able (or potentially able) to contribute actively to the subsistence economy of the community." (105) Mothers nurse children "two to four years" which makes it impossible for a woman to have to infants at one time; the "mobility" of the $:$ tribe and "unceasing effort of women's work" are additional comments for the practices.

The practice of senilicide is based on the same reasons: sometimes the aged request death, if not "others may decide that the day of an aged one is done. . "(106) Same applies to Ammasselik(70) * (Caribou Eskimo--live on barren grounds of Hudson Bay).

Other These practices occurred in the past; most modern day Eskimos were told about infanticide, invalidicide, or senilicide by their parents, but they have never witnessed or hear about it now.

* live in long houses in different places each winter in family/group unj in summer break up into indiv. family units; live in tents and move from place to place. Mobility imp to them. Impossible to accumulate large amt of food so can go from plenty to starvation quickly. 
Author / Skinner

Roference :

Group Data

Q3.7,

Card: 115 Category:

164

North America

NG6

HRAF Code: NG6

Name of Culture Unit: Northern Ojibwa

Northern Ojibwa

Location of group, society, culture: Centered about upper Great Lakes (Superior and Huron) in Canada and United States

Time Frame: (1909) $\$ \$ 142$.

Type of Society: Means of Subsistence: Fishing (trolling), hunting, gathering, later cultivation of wild druits, berries, vegetables

Number and/or Type of disabled persons: Numbers not cited.

Types: aged and infirm

$$
\text { insane }
$$

idiots

Sperial Attention to Disabled:

Positive: "aged and infirm were well taken care of, but this was not always the case according to me of the older observers."

Negative: In earlier days "the aged men were sometimes killed by thej sons and when an old man was reluctant to die, his children would sometimes offer him the alternative of being put ashore on some island with a canoe and paddles, bow and arrows, and a bowl from which to drink, to run the risk of starving:. .old people usually preferred to be killed according to custom" A "dog feast" was given, song sung (see quote) songs and dances followed;'sion killed father with a tomahawk." The body was prepared and buried according to ritual.('152) (Long quoted)

General Infanticide/Senilcide: Senilicide practiced in early times

Infanticide/senilicide (disabled only): Senilicide practiced in early times

Comments: Senilicide evidently not practiced around 1909.

"Owing to the hard life led by these people, cripples and deformed persons are frequent." (161)

2)* Other "idiots are throught to be possessed of devils and are accordingly killed by shooting or strangling and their bodies burned. Formerly, they were burned alive and it is strongly suspected that this is still occasionally done. - (161)" Insane burned alived also. (167) 
duthor: arant, Peter

North America

Reference: HRAF Guide

Group Data

NG6

Ojibwa

HRAF Code: NG6 Card: 115 Category: 888

Name of Culture Unit: Ojibwa

Location of group, spciety cuiture: Centered about upper Great Lakes (Superior and Huron) in Canada and United States

Time Frame: (1791-1804) 1890

Type of Society: Moans of Subsistence:/fishing, hunting, gathering, later, cultivated or wild fruits, berries, vegetables

Number and/or Type of disabled persons: numbers not mentioned. Types: aged and infirm

Special Attention to Disabled: If, "from extreme age or other infirmit the become incapacitated to follow their encampments, they are considere Positive: (useless) "dead to society" and are left behind to die.( 36

Negative: Practice senilicide

General Infanticide/Senilcide: Yes, Infanticide/senilicide (disabled only): Yes

Comments: "They respect their old men while they are of some use in society, but if, from extreme age or other infirmity, they become incapacited. - they are considered dead to society and their nearest relations no longer think themselves bound to maintain them."(365)

\section{Other}


Author: 1: Jenness

Roference:
Disability

Group Data

North America

NG6

Eastern Ojibwa

Perry Island

HRAF Code: NG6 Card: 061 Category: 683, 732

Name of Culture Unit: Eastern Ojibwa

Location of group, society, culture: Perry Island,

Time Frame: (1:929) 1935.

Type of Society: Means of Subsistence: Fishing (trolling), hunting, gathering, later domestication/cultivation of vegetables, fruits, berri Number and/or Type of disabled persons: numbers not cited.

Types: cripples or persons who suffer from other infirmities (84)

\section{Sperial Attention to Disabled:}

Positive: Disabled given role of sorcerer; this had po. sitive effect in that it provided them a place in their society.

Negative: Many sorcerers are cripples or suffer from some gther infirmity because their medicine power has turned against them. "2 The author explains that "medicine" i's given powers of its own; if a man is particularly successful, it is because he possesses a medicirfe that he is not sharing with others. "Witchcraft is, therefore, a very dangerous profession." ". . medicine power of a sorcerer or may be ployed for either good or evil, but if he refrains altogether from its use, it will turn and kill either himself or his children." $(84)$

General Infanticide/Senilcide:

Infanticide/senilicide (disabled only):

Comments: In earlier times sorcerers were put to death by the Indians when they believed that sorcers were not using their "medicine power" for the benefit of the tribe, group. "2This explains why cripples and other unfortunates were particulary exposed to charges of sorcery, and suffered accordingly." (84)

\section{other}


Author: ${ }^{<:}$Landes

Reference:
Disability

Group Data
North America

NG6

Southern Ojibwa

\section{HRAF Code: NG6 Card: 112 Category: 847}

Name of Culture Unit: Southern Ojibwa

Location of group, soclety, culture: Around Lakes Superior and Huron

Time Frame: (1932-35) 1937; (8: Landes; ca 1932) 1938

Type of Society: Means of Subsistence: fishing, (trolling), hunting, gathering, later cultivation of berries, fruits, vegetables.

Number and/or Type of disabled persons: numbers not given; one woman cited.

Woman "notorious for the abortive measures she practiced on herself;"

it was suspected that these abortions were actually murders, for she carried her pregnancies through, or nearly. through, the full term." Special Attention to Disabled:

Positive: (8: Landes) Women who loved their husbands took care of them when they were "incapacitated" in some way. "Marsh Woman's husbanr was paralyzed by sorcery," after two years of marriage and she had a baby. "He became paralyzed in his legs and one arm the was able to move just one arm. For ten years he suffered like that." Marsh woman workec so shpport hind and their children; her parents helped some; her son-inNegative: infanticide (2: Landes)

\section{General Infanticide/Senilcide:}

Infanticide/senilicide (disabled only): Infanticide labeled "abortion" being practiced as late as 1932-35.

Comments: The author states "There is very slight interest in birth control.

*The condition (hydrocephaly) was disagnosed by the Medicine Man to be caused by "abnormal relations between an cunt and her ndiece."(54)

Other Wives who cared for husbands with disabilities did not appear to be unusual; it would be interesting to know if this type of husband/ wife relationship existed in the early days. 
juthor: 15: Hilger

Reference:-
Disability

Group Data
North Aluerica NG6

Southern Ojibwa

HRAF Code: NG6 Card: 110 Category: 826,843

Name of Culture Unit: Southern Ojibwa

Location of group, society, culture: Around Lakes Superior and Huron Time Trame: (198z-1940),1951

Type of Society: Means of Subsistence: Fishitig (trolling), hunting, gathering and later cultivation of berries, vegetables, and fruits

Number and/or Type of disabled persons: numbers not cited.

Types: large head and feeble limbs (infant)

crippled, club-footed, pigeon-toed

Spexial Attention to Disabled:

Positive: "respect for older people, evidenced in speaking to them in a civil way and in listening to them attentively, was well impressed upon children. - Mother would tell us that if we met a blind man, to lead him; if a hungry man, to feed him; or if we found an old person. alone to help him." ( 98$)$

\section{Negative:}

General Infanticide/Senilcide: Senilicide seems to have died out by 1930's; infanticide

Infanticide/senilicide (disabled only): illegitimate infants. author states: "Infanticide of either illegitimate children or other children had not been heard of by any informants, other than the two accounts given above (pp. 30,33)."

Comments: Author relates disablities caused from eating certain foods during pregnancy; information based on "Old Indian superstitions.) (7) vertebrate animal - child's head large and limb's feeble porcupine - crippled, clubfooted, or pigeon-toed

\section{Pther}




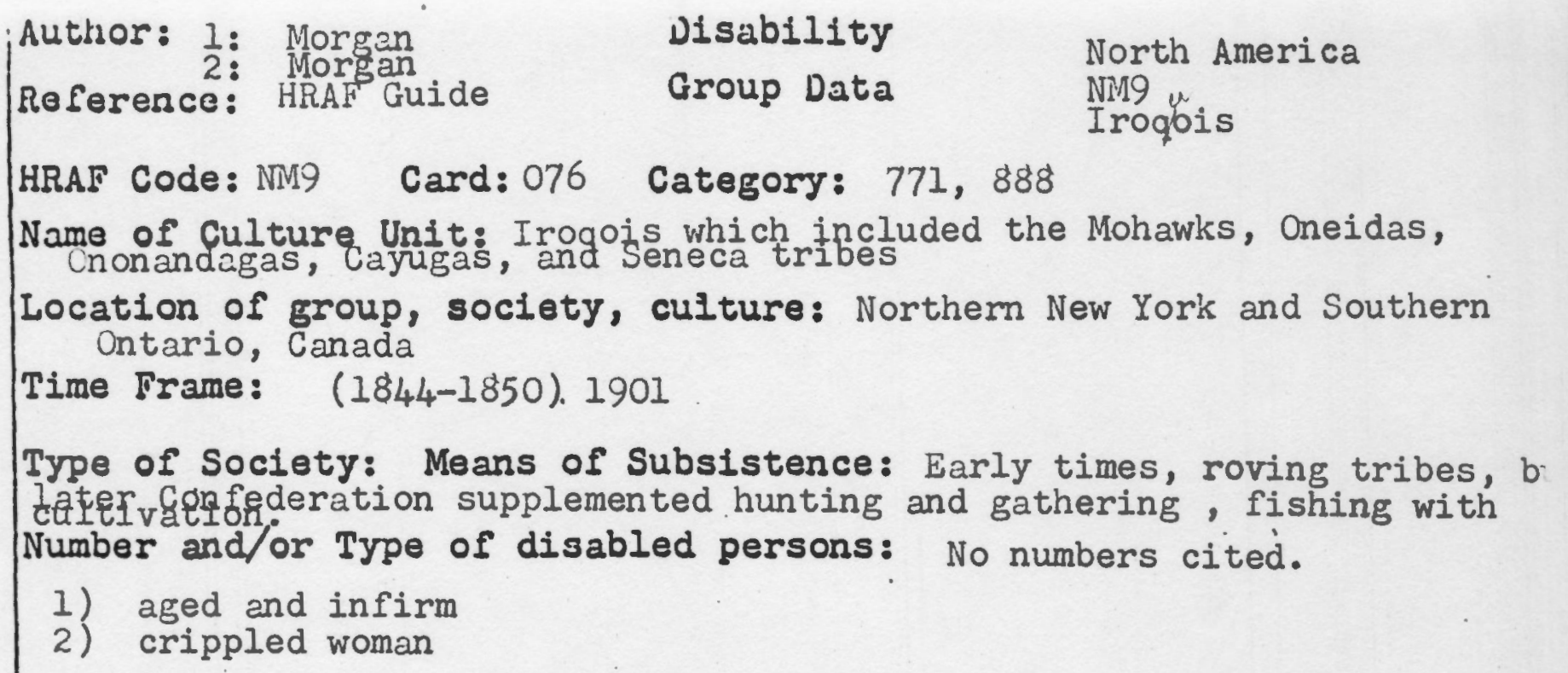

\section{Spexial Attention to Disabled:}

Positive: "roving tribes" probably practiced senilcide, but "at the epoch of the formation of the League, (the Iroqois) resided in ariog permanent villages," which afforded a refuge for the aged.". " "their religious leaders inculcated the duty of protecting their aged parents, as divinely enjoyed." "It is the will of the Great Spirit that you reverence.the'aged, even though they be as helpless as infants."

Negative: Iroguois practiced infanticide, invalidicede, and senilicide; they put cripples to death if they were not mobile.

General Infanticide/Senilcide: Senilicide: "The custom of putting to death the aged and helpless is widespreat. It was intended as an act Infanticide/senilicide (disabled only): of kindness, not as a cruel ty. . Thus a cripple who could not be carried on a journey would be des patched as would.a young infant whose mother had died or an old person belonging to an indigent house. If the house were wealthy, the old woul be preserved alive. . ."

\section{Comments :}

\section{Other}




$\begin{array}{lll}\text { Autbor: 40: Fenton } & \text { Disability } & \text { North America } \\ \text { Reference: } & \text { Group Data } & \text { NM9 } \\ & & \text { Iropótis }\end{array}$

HRAF Code: NM9 Card: 024 Category: 164

Name of Culture Unit: Irogois Location of group, soclety, culture: Northern New York and Southern Ontario Canada

Time Frame: 1750's and earlier;

Type of Society: Means of Subsistence: Hunting, gathering, fishing, and later cultivation

Number and/or Type of disabled persons: 1 crippled woman cited;

types of disabilities found: rheumatism "often leading to lameness, deafness or blindness." (509)

Spexial Attention to Disabled: No special attention noted, but the fact that disabiling sonditions are listed and that disabled persons are Positive: present in society indicates, that they are part of their society.

Negative:

General Infäticide/Senilcide:

Infanticide/senilicide (disabled only):

Comments:

other 
$\begin{array}{lll}\text { Author: 25: Waugh } & \text { Disability } & \text { North America. } \\ \text { Reference: } & \text { Group Data } & \text { Iroquiśs }\end{array}$

HRAF Code: NM9 Card: 075 Category: 847

Name of Culture Unit: Iroquois

Location of group, soclety, culture: Northern New York and Southern Ontario, Canada

Time Frame: (1912-1915), 1916

Type of Society: Means of Subsistence: Hunting, gathering, fishing and later cultivation.

Number and/or Type of disabled persons: Numbers not cited.

Type: In a description of "corn bread.liquor", the author notes that it was sometimes used"as a food for infants. Infants "are said to have been sometimes put to death by the Onondagas, when the mother died, by way of making sure that they should not suffer from neglect." If the mother died, the father "sometimes took corn meal gruel in hismouth and

spexial Attention to Disabled: : let the baby suck it out." (84)

Positive: Society/tried to find way to feed infant if mother not alive to nurse it. ....

Negative:

General Infanticide/Senilcide: In early days, yes.

Infanticide/senilicide (disabled only): Probably not often or not known during this period:

Comments:

Other 


$\begin{array}{lll}\text { Author: 7: Talayesva } & \text { Disability } & \text { North America. } \\ \text { Reference: } & \text { Group Data } & \text { NT9 } \\ & & \text { Hopi }\end{array}$

HRAF Code: NT9 Card: 037 Gategory: Categ

Name of Culture Unit: Hopi, Oraibi

Location of group, society, culture: Center of Black Mesa, Arizona

100 miles east of Grand Canyon; 60 miles north of Sante Fe railroad

Time Frame: (1890-1940) 1942

Type of Society: Means of Subsistence: horticylturalists;

Number and/or Type of disabled persons: numbers not cited.

type: aged infirm

crippled man

insane man

\section{Special Attention to Disabled:}

1) Positive: Crippled man cared for by his family; the elderly were cared for. One, "He was nearly blind now but an important old man, and whenever he talked everyone listened closely. 1 ."(306)

2) "Although he was somewhat deaf, he was still an important man in the Soyal. - "By then the Hopi rule of respect for old age was breaking down. . "(312)

Negative: "and, except on ceremonial occasions, some of the children teased Kayayeptewa, treated him unkindly, and even played practical

jokes on him, such as throwing sticks at him and tying dirty rags on his back. - But during the last two or three years of his life he was of $n$ use to anybody." "the storyteller's mother cared for the old man) (312

3) Crippled man, Naquima, was cared for, but had to crawl or be carried in order to get around . nothing rehabilitative was done for him. Whe Naquima's grandfather died, fe worried about who would care for hij

General Infianticide/Senilcide: Evidently not at this time, but probably earlier

Infanticide/senilicide (disabled only):

Comments: The insane were allowed to be free, and in the instance described by the author, the family departed to "Shongepavi our ancestral home" in order to escape being around "a middle-aged ceremonial son" who had become violent. (74)

Other Naquima, the cripple, had attempted to follow the family, and when the grandfather found him, he put him on his back and carried him to Shongepari too. (74) 
HRAF Code: NT9 Card: 101 Category: 159, 826 card 078;732

Name of Culture Unit: Hopi, Oraibi

Location of group, society, culture: Center of Black Mesa, Arizona

Time Frame: (1932-1966) 1972

Type of Society: Means of Subsistence: Horticulturalists;

Number and/or Type of disabled persons: number not cited:

Type: albinos

cripple

blindness

\section{Sperial Attention to Disabled:}

Positive: "His sister is an albino, but is normally accepted in the community." (88) ... .

whe new leader was an albino who was nicknamed Qotctaka (literally,

white man, but not to be confused with Bahana). ". Nakwaiyamptiwa neve married."

Blindess - if father becomes blind, son will delay marriage so as not $t$

Negative: 1: Titiev: Nakwaiyamptiwa never married,"'because in those days " ladies did notlike albinos."

*deprive household of his services."( card 078: 732)

General Infanticide/Senilcide:

Infanticide/senilicide (disabled only):

Comments: "The Hopi lack explanations of this phenomenon, but do not ascribe it to the supernatural. 1?. [More than two decades later Ned repeated the same ideas on albinism but added that he knew of one case where a married man had had an albino child because he had stolen a sacred doll." ( 88$)$ There is a conflict here.

Other Hopi also believe that "while crippled man's mother was carrying him, she had an affair with a man in ceremonial costume. As sexual relations are taboo for all participants in rites, the child was born badly crippled."(159) (Is this same person that Talayesva called called "Naquima?" This man's name: Nakwavei'ma.

Footnote refers to Parsons, 1925, p. 101 who noted that if a Powamu chie had sexual relations with women while engaged in a ceremony, the poople will have rheumatism and be crippled." (p. 206-A) 
Autsor: Brandt, Richard B.

Reference : Hopi Ethics A Theoretical Analysis

HRAF Code: NTY Card:

Name of Culture Unit:
Lisability

Group Data
North Americz NT9

Hopi

Location of group, society, culture: Northerm Arizona, about 75 mile: northwest of Winslow and about 100 miles east of the Grand Canyon.

Time Frame: c. 1950's but author refers to Hopi's long occupation of area, c. a. d. 1200 .

Type of Soclety: Means of Subsistence: Horticulturalists;

Number and/or Type of disabled persons: numbers not mentioned. Types: blindness (156) insanity ( 358 )

\section{Sperial Attention to Disabled:}

Positive: Aged and helpless cared for by some families and in some instances.

Nothing restrictive is done to an insane person because he/she is "possessed" this has advantages and disadvantages because insane person can be destructive. (358)

Negative: Punishment of children could be severe enough to kill them in that case, some children were probably permanently disabled because of punishment. (78)

Care of aged: "There is evidence. . that the obligation ta care for even needy parents is not strong enough to induce some Hopi to undertak his burden." (193) 24 "A man or woman with ceremonial position or some other basis for respect is more likely to be well treated; those with affectionate relatives. The prospect of the others is more bleak."(193

General Infanticide/Serilcide: Yes, rare, but illegitimate children are a disgrace. Mother or family could kill infant. (189-190)

Infanticide/senilicide (disabled only): Yes, "The parents letting a child die because it was born deformed." Total blindess was suggested that the parents, had in mind that the child would have a hard, unhappy existence and be a problem to raise." (156)

"We can't kill a child even if it suffers. You can pray he'll be taken away." (359) In days of famine It was flaimed that henipldren were eatsp.

Comments: "Hopi views about the neglect/were not investigated in the systematic survey in 1966."(193)

\section{Dther}


Author: Shuman, Márcolm K. Disability

Reference: "Culture and Deaf-Group Data

North Americ Yucatan

ness in a Maya Indian Village," in: Psychiatry, Vol. 43, November 1980 HRAF Code: NV10 Card: Category:

Name of Culture Unit: Mayan Indians

Location of group, society, culture: Village of Nohya, in central par of the Yucatan. Peninsula of Mexico.

Time Frame: "Until about 1976-1977, Indians cut off from rest of world electricity installed in 1977.

Type of Society: Means of Subsistence: hagricultureficorm;

Number and/or Type of disabled persons: Predominance of deaf persons: In 1980(?) there were 300 inhabitants in village;"12 persons or $4 \%$ of population was deaf. There were seven deaf males, and 5 deaf females who ranged in age from 47 for oldest to 3 for youngest. 1 female is only partially deaf; the phenomenon appears to be relatively recent, appearing in only two generations." (359-360) Probably from a recessiye Spexial Attention to Disabled:

Positive:". . it is difficult to detect any overt stigma attached $t$

1) their handicap. ...the deaf villagers are regarded rather matter-of-fac ly as disadvantaged persons "who are, nontheless, capable of functinning adequately within the society. They are referred to as mudos, the spanish word for "mute,". . . but this term is not pejorative." (361)

2) Deaf use sign language to communicate.

Negative: "However, there are subtle, or covert, differences between their position and that of the hearing. The fact that as yet no deaf person has married is one example; also, there is some tendency for the deaf to "form a single association."(36i) Deaf males associate more wit the hearing than deaf women who tend to stay more at home. ". . . for purposes of casual socializing, the deaf are largely excluded by the nature of the oral medium, and often prefer to converse among themselves,

3)* using their sign language."(361)

General Infanticide/Senilcide:

Infanticide/senilicide (disabled only):

Means of subsistence for deaf: same as other villagers. "...all the deaf seem to be excellent workers, the males going into the corn fields and participating in communal projects alongside the hearing and the wo men cooking and caring for younger siblings." (also women make hammocks) Comments:

The people of Nohya appear to have adjusted or adapted to the deaf in community in a non-traditional way. Shuman says: "Traditionally, the

* handicapped have been regarded with fear and awe by the Maya (Juan Ramoi Bastarrachea, personal communication), but there is no indication that these attitudes exist toward the deaf in Hohya."(361)

other

"In Nohya, everyone knows the manual communication system utilized by th. deaf, and there is no onus attached to its use; on the,contrary, sign language is positively valued as another tool which people use." (367)

But the author points out that there are problems of "ambiguity and imprecision," which causes "confusinn" and "insome cases increases isolation." (367)

*3) There is a fatalistic tendency in the "cultures of MesoAmerica" which is found in Nohya and villagers explain deafness as "destiny" This infers

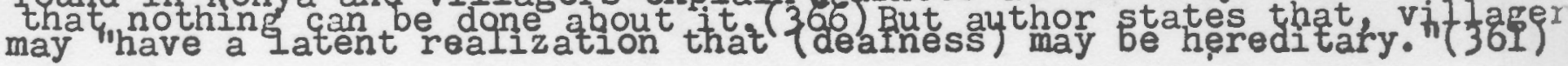


juthor: 1:Steggerda

Reference: Thompson

Group Data

HRAF Code: NVLO Card: 065 Category: 732,847

Name of Culture Unit: Mayan Indians

Location of group, society, culture: Yucatan

Time Frame: (1931-1939)-Steggerda; (1927-1929)-Thompson

Type of Society: Means of Subsistence:

Number and/or Type of disabled persons: Numbers not mentioned.

Types - feebleminded mental illness

aged

Sperial Attention to Disabled:

Positive:

Negative:

General Infanticide/Senilcide: "abortion and infanticide are rela-
tively unknown."(Stezgerda:87) Infanticide/senilicide (disabled only): Senilicide--no; "Respect seems entirely reserved for those of considerable age." (Thompson:86)

comments:

Other 
AuEdo-: 2: Barton

disability

Reference:

Group Data

Oceania

OAl9

HRAF Code: OAl9 Card: 067 Category: $672,554,732,164$,

Name of Culture Unit: Ifuago

Location of group, society, culture:

Time Frame: (1308-1914). 1919

Type of Society: Means of Subsistence:

Number and/or Type of disabled persons: Numbers not cited.

Types: "cripples and unfortunates (68).

1) ichthyosis - skin disease

2) paralysis from knees down; crawled on dill fours.

1)

Special Attention to Disabled:

Positive: Author quotes from legal provisions: "89a Cripples and Unfortunates. - Eripples and those afflicted by disfigurements or disfiguring diseases are often in.a desperate mood for the reason that li is not at all precious to them. They are likely to be erratic and to constitute exceptions in punishment of crimes and procedure. . " )69)

2) There seems to be a family care system for the aged. (187)

Negative: Ridicule of persons with disabilities (69)

General Infänticide/Senilcide: Infanticide not mentioned, but "parri cide" of worthless fathers practicesso senilicide seemed possible.

Infanticide/senilicide (disabled only):

Comments: *Author cites case of crippled man, (see individual form) but does not mention the punishment meted out for the crime. Author also mentions "parracide"; this is related to disability in that "the be-all and end-all of Ifugao existence is the family, and not the individual." (120)

Other 
$\begin{array}{ll}\text { Author: Stewart, Kilton } & \text { Disability } \\ \text { Reference: Pygmies and Dream Group Data }\end{array}$

Oceania

Phillipines

Ifuago 3 Giants

HRAF Code:

Card:

Category:

Name of Culture Unit: Ifuago, Ilongots, Kalingas, Kankanai, Bontocs?

Location of group, society, culture: North Central Luzon, Northern territory of the Zimbales Mountains,

Time Frame: c. 1950's.

Type of Society: Means of Subsistence: Hunting and gathering (30)

Number and/or Type of disabled persons: Excepting for mentallyill, cribing deities and their powers author mentions: "The Taiyaban-flying monsters--whom he mentioned as the twenty-sixth order of the gods, devoured the Souls of the Dead and the Soul-stuff of the living, causing blindness, paralysis, deafness and the like. . " (231,242-3) Disabled persons exist among the Negritos,

Special Attention to Disabled:

Positive:

Negative:

General Infanticide/Senilcide: "practiced infanticide in that the natives killed the younger of all twins." (161)

Infanticide/senilicide (disabled only):

Comments:

Other 
Author: Stewart, Kilton Disability

Oceania

Reference: Pygmies and Dream Group Data Phillipines Ifuago 3 Giants

HRAF Code: Card: Category:

Name of Culture Unit: Ifuago, Ilongots, Kalingas, Kankanai, Bontocs .

Location of group, society, culture: North Central Luzon, Northern territory of the Zimbales Mountains,

Time Frame: c. 1950's.

Type of Society: Means of Subsistence: Hunting and gathering (30)

Excepting for mentallyill, Number and/or Type of disabled persons: /None mentioned but when decribing deities and their powers author mentions: "The Taiyaban-flying monsters--whom he mentioned as the twenty-sixth order of the gods, devoured the Souls of the Dead and the Soul-stuff of the living, causing blindness, paralysis, deafness and the like..." (231,242-3)

Disabled persons exist among the Negritos,

Spexial Attention to Disabled:

Positive:

Negative:

General Infinticide/Senilcide: " practiced infanticide in that the natives killed the younger of all twins." (16I)

Infanticide/senilicide (disabled only):

Comments:

Other 
14: Lambrecht; 9:Lambrecht

Disability

Reference:

Group Data

Oceania

OA:19

Ifuago

HRAF Code: OA19 Card: 067 Category: 732,755,

Mayawyaw

Name of Culture Unit: Ifuago, Mayawyaw

Location of group, society, culture:

Time Frame: (1924-1940) .1955; 9:Lambrecht (1924-ca. 1940) 1932-1941

Type of Society: Means of Subsistence:

Number and/or Type of disabled persons: Number not mentioned.

Type: The "Ullap Ritts" described, whichllists the icauses of blindness. The Mayawyaw admit that, if some one becomes blind after a long disease of the eyes, becoming worse year after year, no rites or sacrifices will ever cure the blindess; they also admit the incurability of someone born blind. But if someone is struak blind suddenly, rites tho Sperial Attentión to Disabled:

1)

Positive: Rites and rituals for blind performed in order to restore them to sight.

2) "aged widows and widowers. . may live in the house of one of their mar ried children, or, if they happen to have no children; even in the hous of one of theif neices or nephews. "(187)

Negative:

General Infanticide/Senilcide: There does not appear to be infanticide or senilicide.

Infanticide/senilicide (disabled only):

Comments: See xerox for quotes from ritual. "Here your victim/ Bright Being Bugan wife of the Sun and lingan the Moon/ who sent (/) the blindnesses all of them,/ your blindness Bright-being Bugan wife of the Sun Lingan the iloon, $\%$. . ."(95)

"The Mayawyaw Ritual - The priest repeats then the invocations of the mi - He kills then a smali chicken saying: Here your victim,/Night-bei bther of the Skyworld and Star-deities/ we offer it to you so that you may drive away the clouds from the eyes of Wigan, etc. . "(96) 
Author: Jensen, Erik

Roference: The Iban and Their Group Data Religion

HRAF Code: Card: Category:

Name of Culture Unit: Iban, and Dyaks, Sea Dyaks

Location of group, society, culture: Malaya, Sarawak, Borneo

Time Frame: c. 1974

Type of Society: Means of Subsistence: Horticulturalists;

Number and/or. Type of disabled persons: Specific number' not mentione Types: "physical disability, in particular, their blindness or poor sight."(145)

Spexial Attention to Disabled: Disabled given special niche, "a legitimate social place," (145) as a manang.

Positive: The manang. "vocation" has several characteristics--1) it has to do with transvestites, homosexuals, and hermaphrodites, but it a so deals with "the world of spirits." "This ties in with. . their ph ical disability. . .their blindness or poor sight." "The world of men and the spirit world are associated with certain opposite values: visib and invisible, light and darkness,. . . which includes seeing and not se Ing Negative: There is a question among anthopologists about the "manan being physically incapable of fatherhood. (FNI, 144-145)

General Infanticide/Senilcide:

Infanticide/senilicide (disabled only):

Comments:

Other 
Author: 7:Gomast.

Reference:

HRAF Code: 0c6 Card: 848
Disability

Group Data

\section{Name of Culture Unit: Iban, Dyaks}

Location of group, society, culture: Malaya; Saxawak; Island of

Time Frame: (ca 1890) 1911

Type of Society: Means of Subsistence: agriculture, fishing

Number and/or Type of disabled persons: Numbers not mentioned. Types: madness (322); Leprosy (322); "Only three cases had muscle wasting that might have been attributable to poliomyelitis, or encephalitis." (326)

\section{Spexial Attention to Disabled:}

1)

2)

1)

2)

Positive: "Harmless lunatics and idiots are allowed their freedom." (322). No mention is made as to subsistence or care. Lepers, although the author only encountered a few, are allowed at large until "the disease is so far advanced as to make it unsafe to let them life with others in the long Dyak house ${ }^{2}$ separate little hut is put up for them at some distance away. "(322)** placed in a wooden cage (bubong). (322) "Nadness is looked upon by the Dyaks as possession by some levil spirit."( 322

) Author cites case of an old/woman; people generally brought,her food a water, but her fire was out for two days before anyone came and she co not cook. She was isolated. and not necessarily cared for.

General Infanticide/Senilcide Yes "if mother "died in childbirth, i was former practice to bury live infant with her." Who would suckle ch" Infanticide/senilicide (disabled only): No mention is made of deformed infants.

Gomes said it has been a long time since such infanticide has been carried out; now Dyaks adopt them. (card o\$3)

, (see card 048; categorgowy 847: Roth for oonfirmation on infanticide.) Comments:

** They are considerate to the aged-and parents who are past work are generally treated kindly."(62)

\section{Other}


Author: Du Bois, Cora

Disability

Oceania

Reference: The People of Alor Group Data

Psychologycal Study of an East Indian Island, Vol. I. ARAF Code: OF5 Card: Category:

Name of Culture Unit: Wountain people at Atimelang in the Barawahing, district.

Location of group society " cuitures "communjty lies above the northwe Time Frame: c. 1950's

Type of Society: Means of Subsistence: horticulture harvest of cassava crop, natives burn over lields.

Number and/or Type of disabled persons: Two insane women; a simpletor and a man who was considered crazy. Another man was blind in one eye as well as crippled. (157-158, 285)

Spexial Attention to Disabled:

1)

2)

General Infäticide/Serilcide:

Infanticide/senilicide (disabled only):

Comments:

Other 


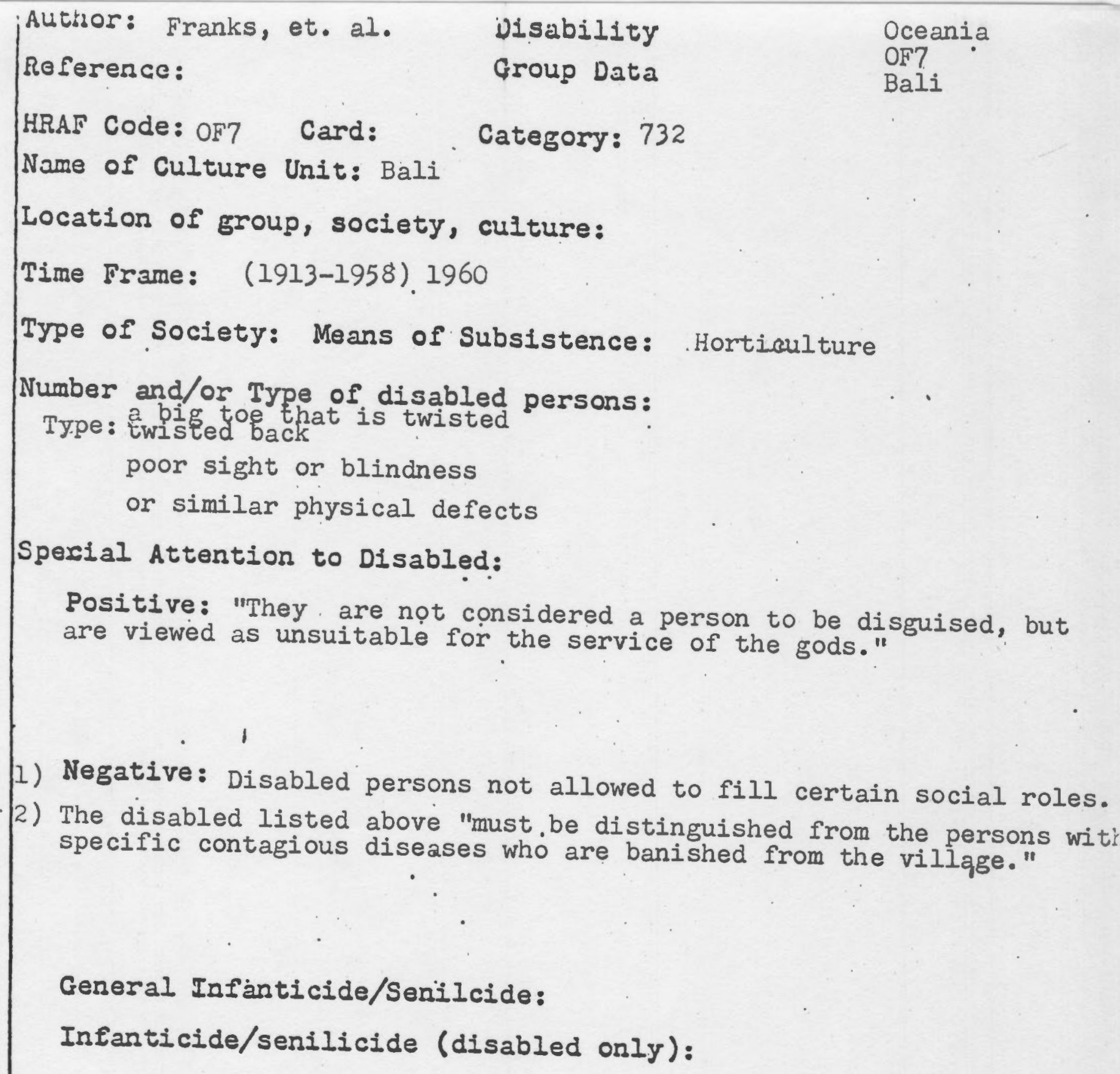

Positive: "They are nọt considered a person to be disguised, but are viewed as unsuitable for the service of the gods."

1) Negative: Disabled persons not allowed to fill certain social roles.

2) The disabled listed above "must.be distinguished from the persons with specific contagious diseases who are banished from the village."

General Infanticide/Senilcide:

Infanticide/senilicide (disabled only):

\section{Comments:}

Other 
Author: Covarmbias

Disability

Reference:

HRAF Code: OF7 Card:

Name of Culture Unit: Island of Bali

Category: $133,754,755,164,732,845$

Location of group, society, culture: part of Malay Archipelago

Time Frame: (1930-1933), 1938

Type of Society: Means of Subsistence: Horticulture;

Number and/or Type of disabled persons: number not mentioned. (144, 303)

Spexial Attention to Disabled: A belief in witchcraft could bring harm to an enemy or cause disability.
Positive:

Negative: Priesthood is denied "lepers, madmen, epileptics, and the deformed."(303) Not allowed to marry, have children. "Tabooed for sexual relations are albinos, idiots, lepers, and in
general the sick and deformed." $(144)$

General Infänticide/Senilcide: Infanticide/senilicide (disabled only):

Comments:

Other 
jAutbor: 2: Wilkin

Reference :

Group Data

HRAF Code: 0G6 Card: 006 Category:

Name of Culture Unit: Sudra, Wesja, Brahman, Satrya, Igorot, Nissans

Location of group, society, culture: Makassar, Southeast Asia

Time Frame:

Type of Society: Means of Subsistence: Fishing and horticulture Number and/or. Type of disabled persons: None mentioned. .

Sperial Attention to Disabled:

Positive:

Negative:

General Infanticide/Senilcide: Yes, twins; some killed immediately; others offered for adoption; if not adopted, they are strangled, or Infanticide/senilicide (disabled only): buried alive. (298' contd) Senilicide not mentioned; appears unlikely since the elderly maintain a great deal of authority over younger people and family.

Comments: There is not " 847 " infanticide category for Makassar which is incorrect since infanticide is practiced in the event of twins. Disabled infants not mentioned.

bthes 
Author: Chabot

Disability

Reference:

Group Data

HRAF Code: OG6 Card: 023 Category: 732

Name of Culture Unit: Kampong Bontorama

Location of group, society, culture: Makassar

Time Frame: c. 1940's

Type of Society: Means of Subsistence:

Number and/or Type of disabled persons: The author points out that the were a high percentage of unmarried people in the population and that c that number there was a high percentage of deaf mutes: "Among the $15 \mathrm{r}$ there were four deaf-mutes. . Among the 24 women there were three deaf mutes ( 1 ) in addition to one blind and one abbino woman. "( $2 \$ 8 / 160$ icont"

Spexial Attention to Disabled:

Positive:

Negative: The author infers but does not state that being deafmute or otherwise disabled, prevented those persons from marrying. (160 con

General Infänticide/Senilcide:

Infanticide/senilicide (disabled only):

Comments:

other 
$\begin{array}{ll}\text { Author: Spencer, Baldwin } & \text { Disability } \\ \text { and Gllen, F.J. } & \text { Group Data } \\ \text { Reference: The Native } & \text { Tribes of Central Australia }\end{array}$

HRAF Code: OII8 Card: 101 Category: 854,847

Name of Culture Unit: Arunta and other tribes of Central Australia

Location of group, society, culture: Central Australia

Time Frame: (1896-c1925) 1927

Type of Society: Means of Subsistence: hunters and gatherers

Number and/or Type of disabled persons: Not specifically mentioned.

Types: aged or infirm people mentioned.(854)

\section{Sperial Attention to Disabled:}

Positive: "There is no. such thing as doing away with aged or infirm people."(854) (book:51)

Negative:

General Infanticide/Senilcide: Yes; infanticide is practiced when th mother is still nursing an infant and does not think she can care for*

Infanticide/senilicide (disabled only):

*another child.9 Twins are killed immediately.(847)

Comments: The natives believe in magic and that it causes sick ness and disaster. In line with this "Near to Charlotte Waters. . . is a tree which sprung up to mark the spot where a blind man died. . . it is call the Apera okilchya, the blind tree, and the spot where it stands, the Mira okilchya, or blind camp."(552) If the tree is cut down, the'men i the bcality would become blind or "if anyone wishes to produce blindnes other in an enemy, he has to go to the tree alone and while he is rubbi it, mutter his desire and an exhortation." (552) Another way a native can produce blindness is to point his "pointing stick". or he will "char a chilora or forehead band, and then present it to his enemy, who after time loses his sight."(553)

No mention is made about how blind get along among natives, but from th above, the blind are present in the group, and much thought is given to the subject. 


$\begin{array}{lll}\text { Author: Spencer and Gillen } & \text { Disability } & \text { Oceania } \\ \text { Reference: The Arunta } & \text { Group Data } & \text { OIld } \\ \text { HRAR Gode. OTl8 } & & \text { ARunta }\end{array}$

MRAF Code: $I I 8$ Card: Category:

Name of Culture Unit: Arunta

Location of group, society, culture: Central Australia

Time Frame:

Type of Society: Means of Subsistence: Huntersand Gatherers Number and/or. Type of disabled persons: none mentioned.

\section{Special Attention to Disabled:}

Positive:

Negative:

General Infanticide/Senilcide: yes, infanticide

Infanticide/senilicide (disabled only): yes, probably. Senilicide: The authors do not mention, if so; they mention haw the elderly men were respected. See senile decay, p. 399. v. II. pp. 300 and 381 - young men open their own veins and give blood to

Comments: The Arunta had a well-developed sign language which they used to communicate with one another when they could see but not hear one an other and when there was a ban on speech.

The author did not mention deafness or k: deaf persons, but if they had deaf people, they could and would have used it. Were there deaf person: pther 
Name of Culture Unit:

Location of group, society, culture:

Time Frame: C. 1970

Type of Society: Means of Subsistence: Hunters and Gatherers

Number and/or Type of disabled persons: Number not cited:
Type: aged infirm

lame

deformed infants

Special Attention to Disabled:

Positive:

Negative: infanticide, invalidicide, senilicide

General Infanticide/Senilcide: Yes, infanticide; yes, venilicide;
also abandoned lame and infirm. ( $98,101,102)$. Infanticide/senilicide (disabled only):

Comments: Auther attributes infanticide, invalidicide, and senilicide to fatalistic attitude of aborigines and not solely caused by ecologic

Other 
Author: Williams, F.E.

Disability

Reference: Orokaiva Society Group Data
OJ23

Oceania

Papua, New Gui: Northern Divis: Orokaiva

\section{HRAF Code: OJ23 Card: Category:}

Name of Culture Unit: Orokaiva Society, Aigu and other tribes

Location of group, society, culture: Northerm Division, Papua, New Guinea

Time Frame: c. 1930

Type of Society: Means of Subsistence Hunters, fishers, gatherers

Number and/or Type of disabled persons: A possible epileptic mentionc (275)

A young man with a congenitally malformed foot. (97)

Spexial Attention to Disabled:

Positive: The young man who appeared to be an epileptic was evider cared for by the tribe.

Negative:

General Infänticide/Senilcide: Possibly; (95-96)

Infanticide/senilicide (disabled only): "It is said that abnormal children would be strangled at birth and buried, and this is probably true." (95)

Comments: Explanations for disabilities, other than the most casual, are supernatural. Attributed to "fiend or hobgoblin the souvai. The epileptic boy who had been missing all day was found in the evening with "cuts on his cheek and hand and traces of earth on his face and body. He offered the explanation that he was taken by a souvai

who caused the wounds by biting him. No one hesitated to belief him, Other though, as he was accustomed to fits of violence and was known to fall into the fire on accasion, we should probably...suppose him. to be epileptic." (275) 
$\begin{array}{lll}\text { Auctor: 24: Kramer } & \text { Jisability } & \text { Oceania. } \\ \text { Reference: } & \text { Group Data } & \text { ORI9 }\end{array}$

HRAF Code: OR19 Card: 037 Category: 757, 755, 164 Name of Culture Unit: Truk:

Location of group, society, culture:

Time Frame: (1907-1910) .1932

Type of Society. Means of Fishing and gathering

Tye of Society: Means of Subsistence: breadfruit (main crop;

Number and/or Type of disabled persons: Numbers not cited.

Truk words Br disabilities listed:. "fens," Trukese Beriberi...
atrophy of the muscles of the limbs.

"Iigayecu," atrophy of the muscles on one side; "peteka," paralysis of Sperial Attention to Disabled:

Positive:

Negative:

General Infäticide/Senilcide:

Infanticide/senilicide (disabled only):

Comments: *"mesedjun, conjunctivitis, blindness; emot, stammering, unin-with these disabilities were present in the population/

bther 
Autnor: 2: Gladwin and Sarasof plsability Reference : Group Data

HRAF Code: OR19 Card: 086 Category: 754, 732 Name of Culture Unit: Truk

Lotion of fishing and gathering

Location of group, society, culture: bread fruit, main crop

Time Frame: (1947-1951). Location:

Type of Society: Means of Subsistence: (see above)

Number and/or Type of disabled persons: 1 ten year old crippled boy;

1 crippled man aged persons

1 paralyzed man

Sperial Attention to Disabled:

) Positive: crippled man trained to be a carpenter under Japanese; "able to be married and support his wife's family rather munificently.

2) generally, elderly not well cared for with exception of those who were "master magicians," spirit mediums,. . ." "Even when they could no longer walk, they were sought after." They" were exceptions because they played an important role in the community." (154)

Negative: Crippled boy teased and ridiculed by children after he

1) became angry "and rushed at the person." He used "a pole which he gripped with his hands. . . one leg was withere."

2) Elderly aged fed enough to be kept alive, but neglected otherwise. (153)

3) Paralyzed man. . ."was kept clean and well but never had company."(154)

General Infántícide/Senilcide:

Infanticide/senilicide (disabled only): "disposal of deformed infants. Unsanitary conditions militate against the survival of any congenitally deformed or traumatized infants." (247)

Comments: Explanation of disability: "Those cases of afflictions, (blindness, psychoses, paralysis which were definitely attributed to given sorcerer" werte hard to check out and "always applied to another island."

pther 
$\begin{array}{lll}\text { Reference: } & \begin{array}{c}\text { Disability } \\ \text { Group Data }\end{array} & \begin{array}{l}\text { Oceania } \\ \text { ORl9 } \\ \text { Truk }\end{array} \\ \text { HRAF Code: ORl9 Card: } 086 \text { Category: 832, } 847 & \text { Name of Culture Unit: Truk } & \\ \text { Location of group, society, culture: } & \\ \text { Time Frame: (1947-1951). } & \text { fishing, gathering } \\ \text { Type of Society: Means of Subsistence: agriculture; breadfruit } & \text { main crop, coconuts }\end{array}$

Number and/or Type of disabled persons: Numbers not cited.

Type: deformed infants

Spexial Attention to Disabled:

Positive:

Negative:

General Infanticide/Senilcide: Some general infanticide.

Infanticide/senilicide (disabled only): / Yes; deformed infants were regarded as work of evil spirits and put to death.

Comments:

pther 
Reference: "The Silent Inventor Group Data

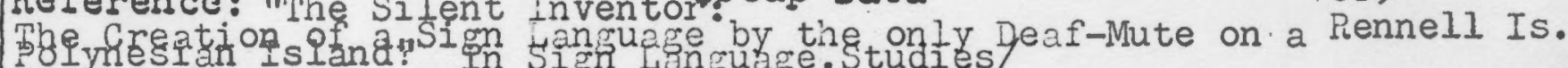
HRAF Code: OT9 Card:

\section{Name of Culture Unit:}

Location of group, society, culture: Rennell Island, part of British Solompn Tstrand Time frame: $1915+$ five years deafmute born on penneli) and March and Type of Society: Means of Subsistence: Gatherers and fishing

Number and/or Type of disabled persons: 1 mentioned, a deaf mute who is the only deaf and dumb person ever known on the Island. The oral tradition goes back twenty-four generations. (3)

\section{Spexial Attention to Disabled:}

Positive: "Despite his exceptional handicap (as viewed with Rennellese eyes) Kangobai must be considered as generally accepted and relatively well integrated in the Rennellese society." (But not totally) $(6 \div 7)$

Kangobai developed the sign language he uses to communicate with the other natiyes but "Without "their cooperation and their wish to bridge the communication gap.". "the sign lanjuage would not exist today. $(7$

Negative: He is not married which is "atypical" on the Island. one person remarked to Kuschel that Kangobai did not speak. "Everyone on the Island speaks." And another man remarked that "Kangobai does be have like a monkey."

\section{General Infänticide/Senilcide:}

Infanticide/senilicide (disabled only):

Comments: Kangobai has developed the only sign language ever used on the island; there is not even a word for a "mute person." (4).

Other Explanation of deaf mutism: There are two native versions of why Kangobai cannot speak: I) his mother broke a taboo when she was pregnan and remarked that "This coconut makes a lovely sound. I would dearly $1 i$ for my son to be able to speak in the same manner."(5) She wished for

- "something not allotted to man." 2) Kangobai's father stole bananas from a burial ceremony his grandfather's brother was performing. (5) 


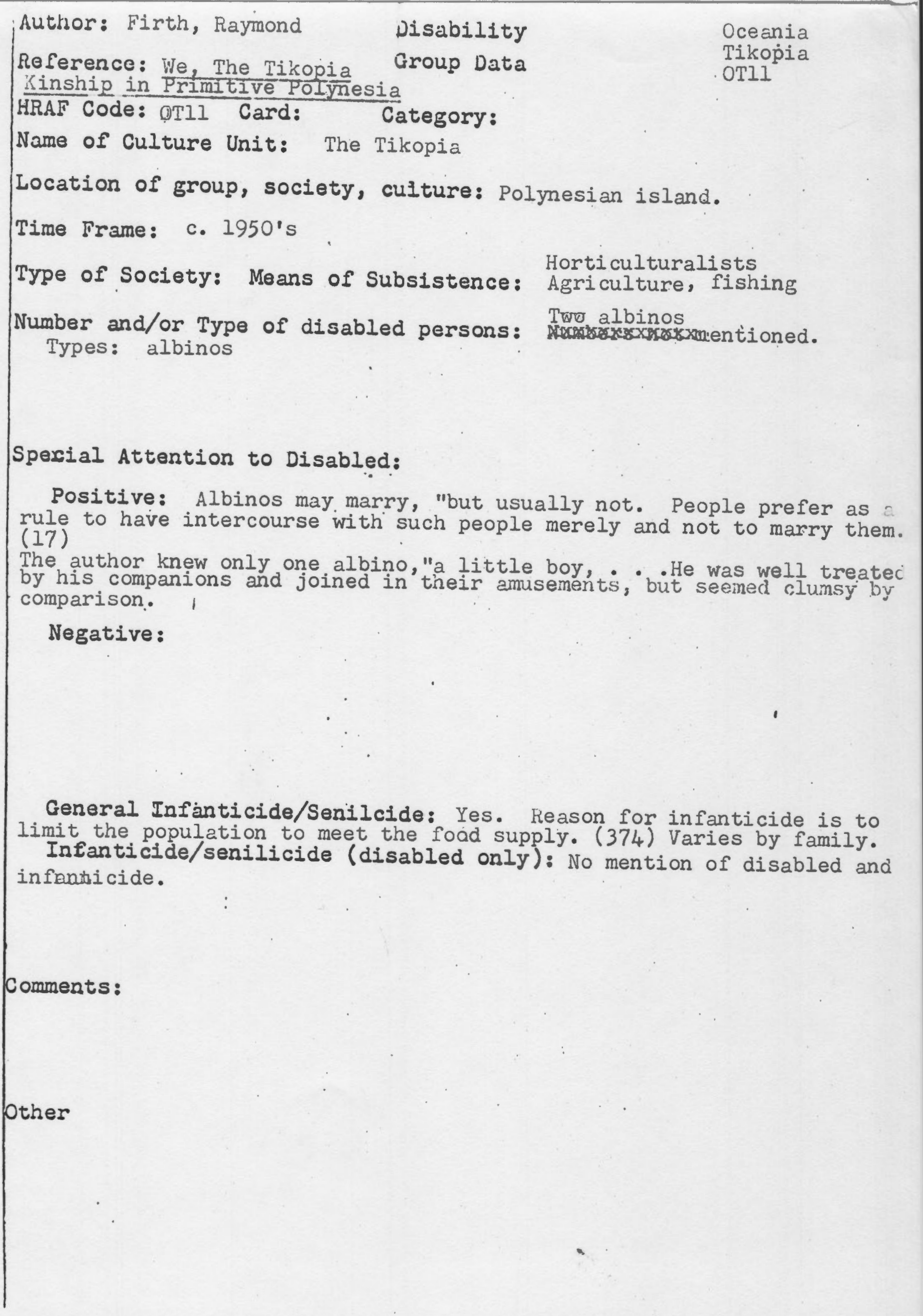




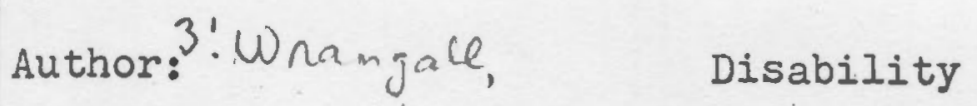

Group Data
Russia

Siberia

Chukchee

RY

Reference:

HRAF CODE: Ry 2, Card: , Category: 847

Name of Culture Unit: Chikchee

Time Frame: $(1826-18) 1844$

Location of Group, society, culture:

Type of Society: nomadic

Means of Subsistence: fishing; walrus, seal, whale hunting other hunting; reindeer grazing; gathering in season Number of Disabled in Group: - - gathering in season Types of Disabled: -

Special Attention to Disabled:

Positive:

Negative: "Killed all deformed child re..), chider wto appeared difficult diner ; and are then oed people" unfit

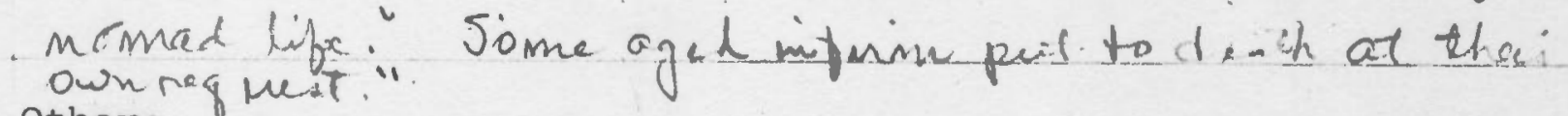
Other:

Gomenal Imfanticil: ?

other. 
Author:6': Hooper

Reference:
Disability

Group Data
Russia Siberia Chukchee RY2

HRAF Code: RY2, Card: 114; Category: 758.

Name of Culture Unit: Chukchee (Maritime)

Location of group, society, culture: Russia Time Frame: (1848-52) 1853

Type of Society:

Means of subsistence: fishing, walrus, seal, whale hunting; reindeer grazing, gathering in season.

Number of disabled in group: Evidently significant number of people suffer from snowblindness/opthalmia

Types of disabled mentioned: Snowblindness and opthalmia disabilities

Special Attention to Disabled:

Positive:

Negative:

Other: anthropologist surprised that no spectacles or protection used against "blinding glare of snow in springtime." 
Author: $6:$ Hooper
Bogoras
Reference:
Disability

Group Data
Russia

Siberia Chukchee RY2

HRAF Code: RY2 Card 131, Category-84?

Name of Culture Unit: Chukchee

Location of Group, society, culture: Russia

Time Frame: (1848-52) 1853 Hooper (1890-1901) 1904-09 Bogoras

Type of Society: nomadic

Means of subsistence: fishing, walrus, seal, whale hunting, other hunting; reindeer grazing; gathering in season Number of disabled in group:

Types of Disabled mentioned:

Special Attention to Disabled:

Positive:

Negative:

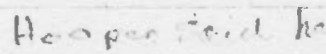

Other: Never heard of instances of infanticide as reported by Wrangell, but also never saw any "deformed children or "children with sickly constitution," so/Wrangall was probably correct.

Bogoras stated, "I know of no such practice (exposure of misshaped infants) in modern times." (Bogozas cited Sarytcheff as first mentioning infanticide of disabled infints) 


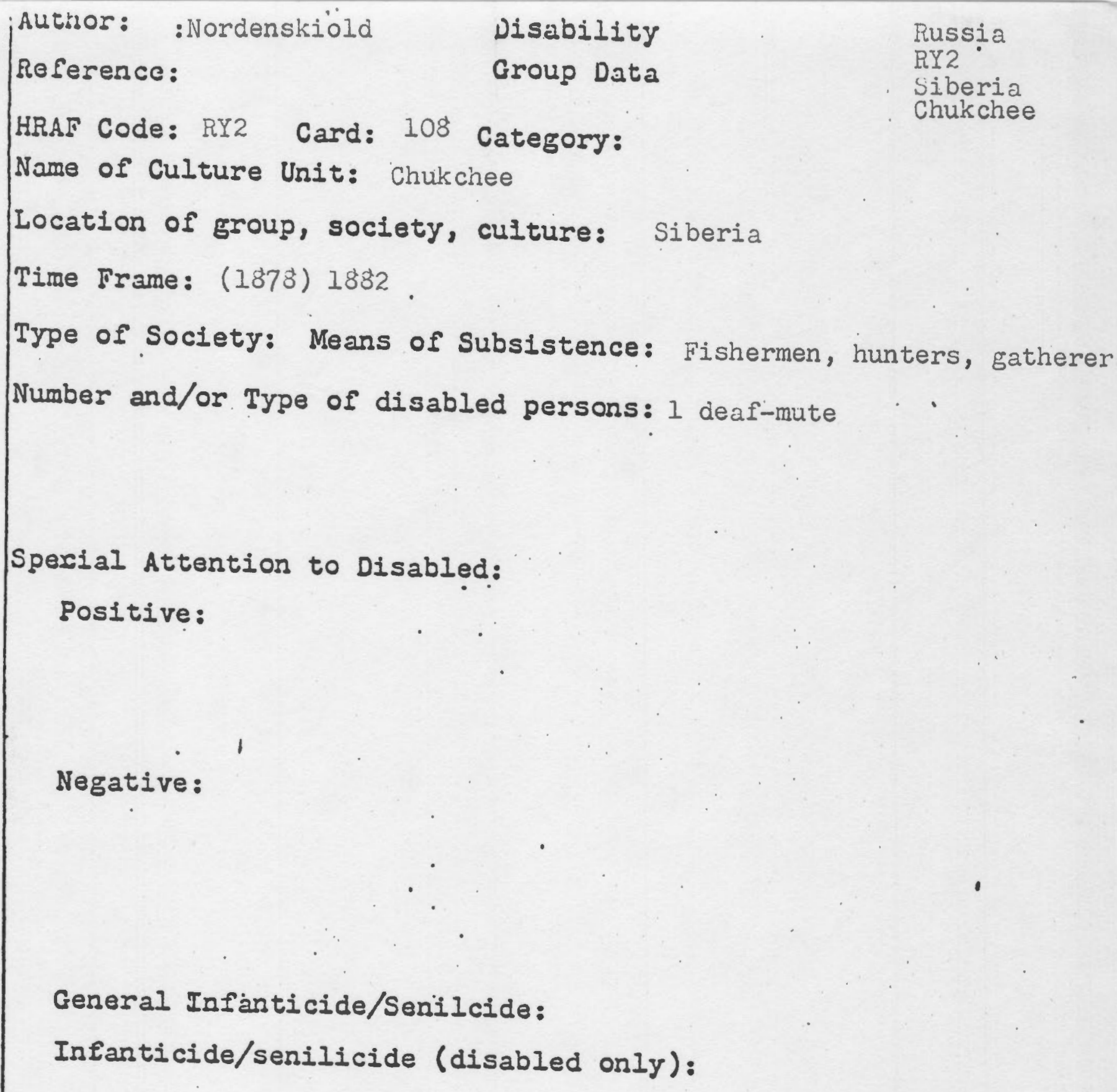

Spexial Attention to Disabled:

Positive:

Negative:

General Infäticide/Senilcide:

Infanticide/senilicide (disabled only):

Comments: Author stated that "Kwuro(JMR: a deaf half-idiot) was however an obliging youth, who during our stay in the tent, did all he could to be of use to us. . He was a skillful archer. .

other 


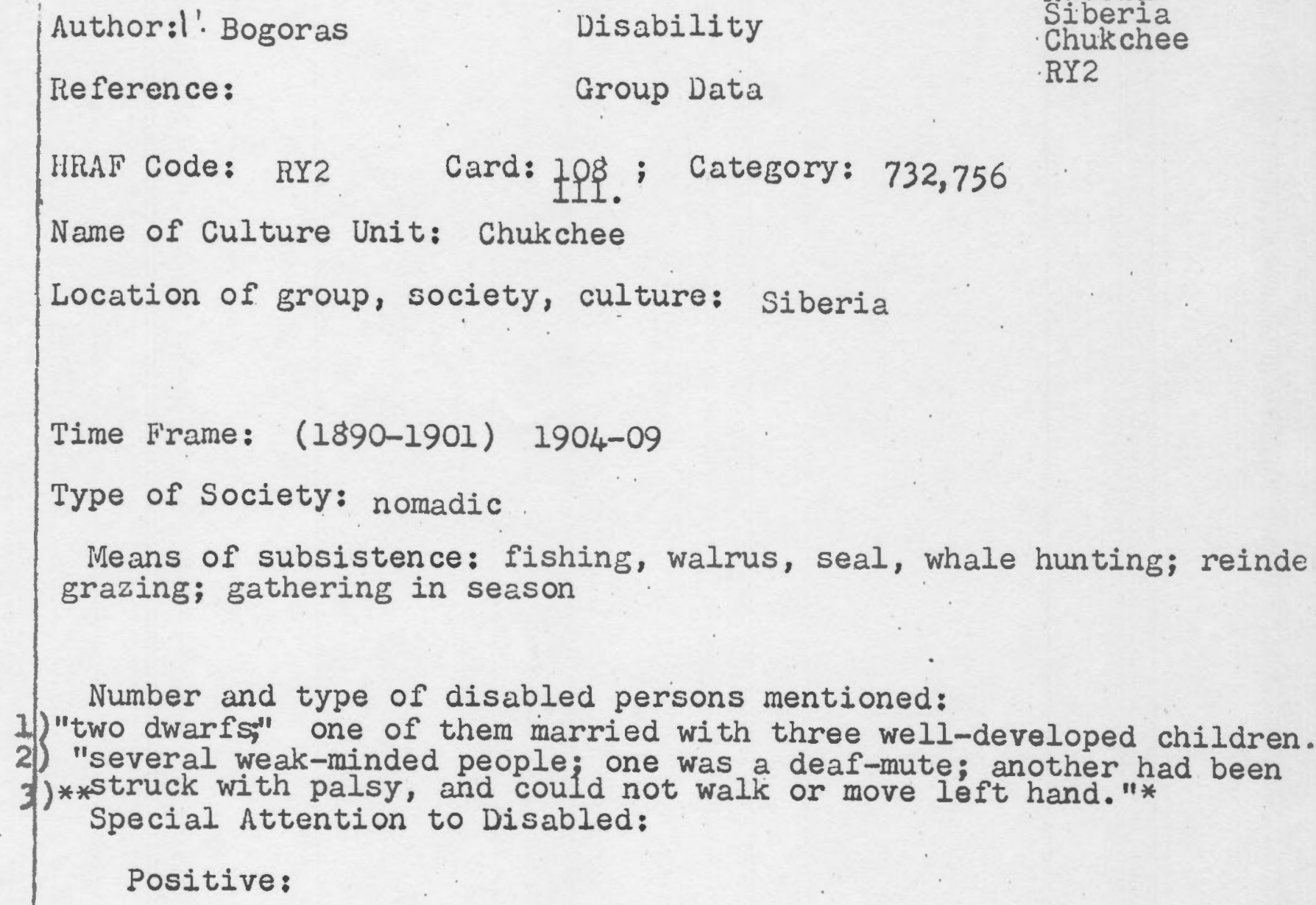

Means of subsistence: fishing, walrus, seal, whale hunting; reinde grazing; gathering in season

Number and type of disabled persons mentioned:

1) "two dwarfs" one of them married with three well-developed children. 2) "several weak-minded people; one was a deaf-mute; another had been Special Attention to Disabled:

Positive:

Negative:

Other Bogaras said, "the Chukchee had no notion of supernatural power possessed by such people, as is held by the American Eskimo."

Bogoras noted that, "Satytchiff says that in his time the Chukchee exposed misshaped infants... I know of no such practice in modern time **"Blindness occurs often, especially among old people." 
Author: I'. Bogoras

Name of Culture Unit: Chukchee

Location of group, society, culture:

Time Frame: (1890-1901) 1904-09

Type of Society:

Means of subsistence: deaf mutes "took part in all the daily pursuits of their camp."

"5 deaf mutes; three full-grown"

Special Attention to Disabled:

Positive: Communicated with deaf by using simple signs, the samc signs that were used in communicating with people who did not understand their language

Negative:

Other 


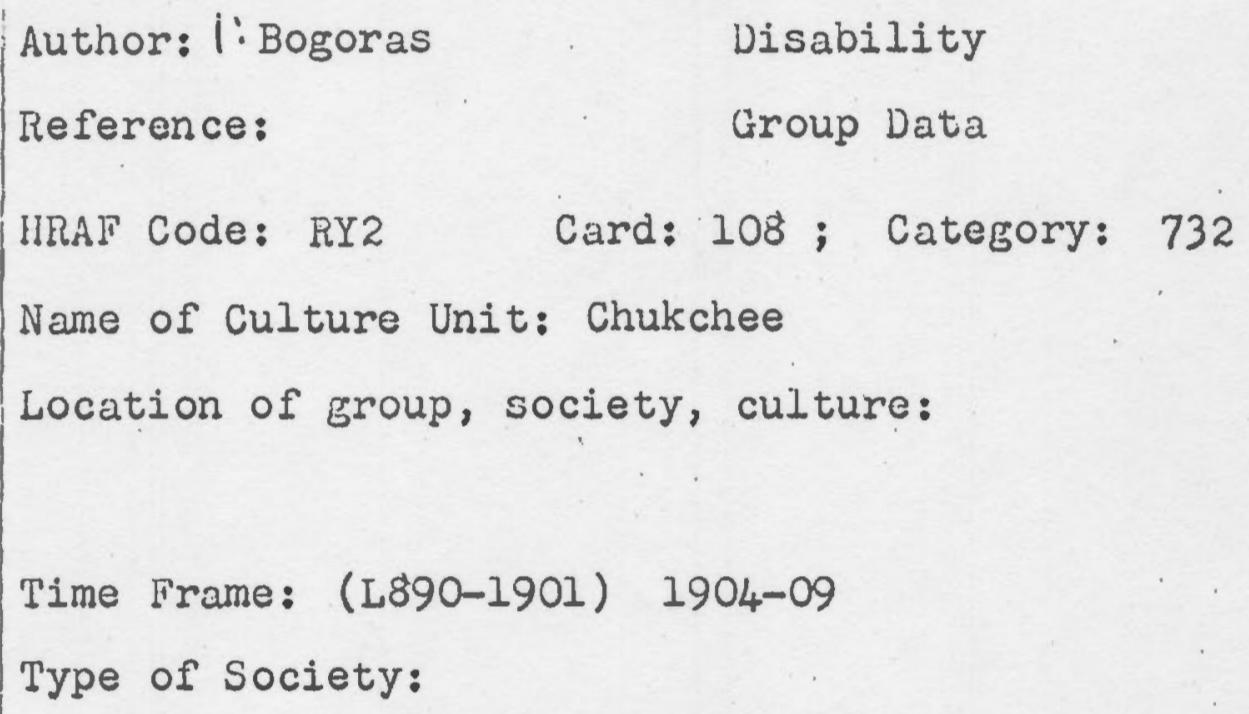

Number and type of disabled persons mentioned: "physically fit men who remain bachelors because of a grafe physical defect which hinder. sexual life."

Special Attention to Disabled:

Positive:

Negative: "incapable of sexual life and (man) cannot have a wife and a home of his own."

Other: "Abnormality expressed in the Chuckchee language by a special verb...'thou acquirest the swelling on the membrum virite." 


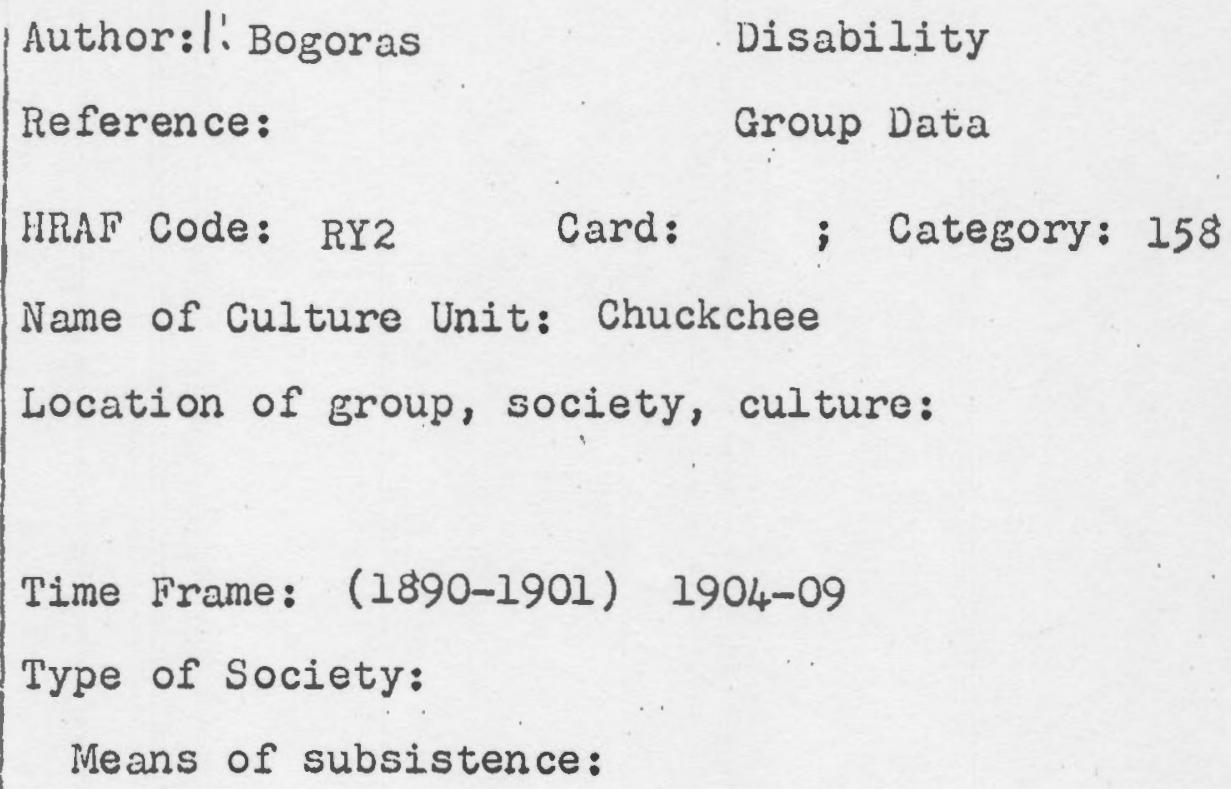

Number and type of disabled persons mentioned: Nervous diseases:

1) "ite'yun, akin to epilepsy

2) "iu'metun, a kind of violent nervous affection which comes on at night like a violent nightmare." (numbers not mentioned) Special Attention to Disabled:

$$
\text { Positive: }
$$

Negative: Nervous diseases "... are dreaded and subject to shunni ... man suffering from iu'metun (if afflicted while travelling) may be almost sure that he will not be allowed to enter any house, nor will he be given either fire or warm food."

Other: 


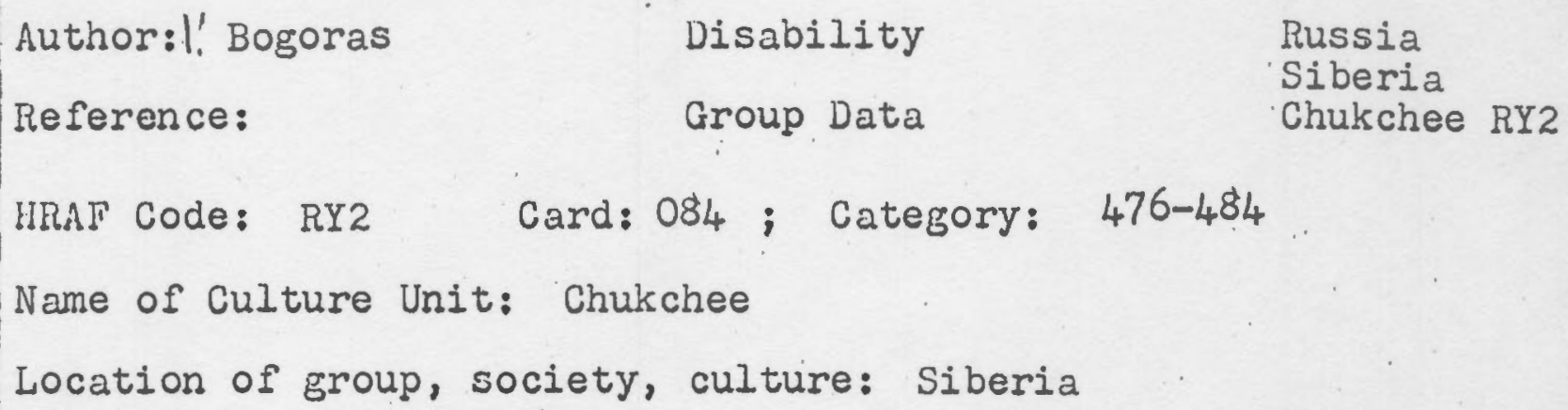

HRAF Code: RY2 Card: 084; Category: 476-4844

Name of Culture Unit: Chukchee

Location of group, society, culture: Siberia

Time Frame: (1890-1901) 1904-09

Type of Society:

Means of subsistence:

Number and type of disabled persons mentioned: no number mentione "Lame people use crutches of various shapes, made in the same way as those used by civilised people."

Special Attention to Disabled:

Positive:

Negative:

Other 
Author:l'. Bogoras

Reference:

HRAF Code: RY2

Name of Culture Location of group, society, culture:

Time Frame: (1890-1901) 1904-09

Type of Society:

Means of subsistence:

Number and type of disabled persons mentioned: 2 mentally disabled mentioned.

1

Card:

; Category: 158

Group Data

Special Attention to Disabled: Positive:

Negative: When woman became violent and would want to harm other people, her housemates would"tie her hands and bind her to one of the house-poles."

2) When man became violent and tried to "injure his companions" was finally put "out of the way" by mutual consent of his companions.

Other: 


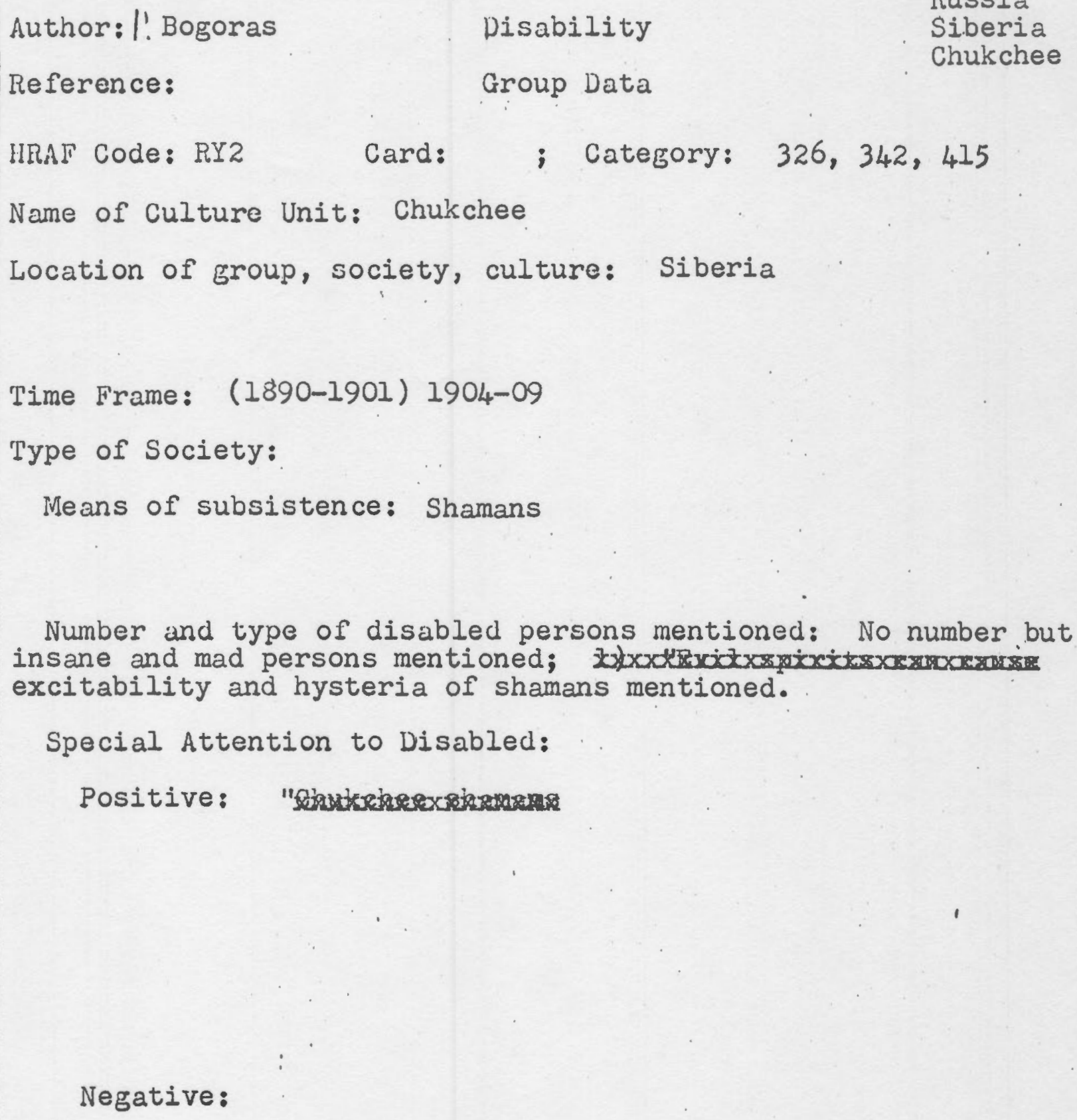

Number and type of disabled persons mentioned: No number but

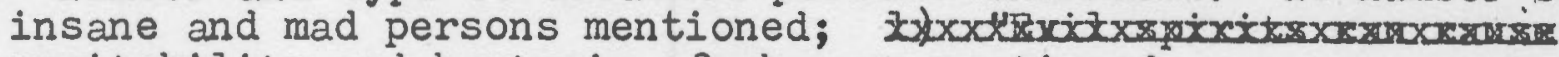
excitability and hysteria of shamans mentioned.

Special Attention to Disabled:

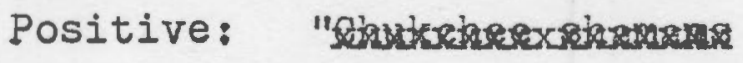

Negative:

Other. Bogoràs commanted that "Chukchee shamans are extremely excitable, and not a few of them were half crazy." "Their cunning in the use of deceit in their art closely resembled the cunning of a lunatic." 


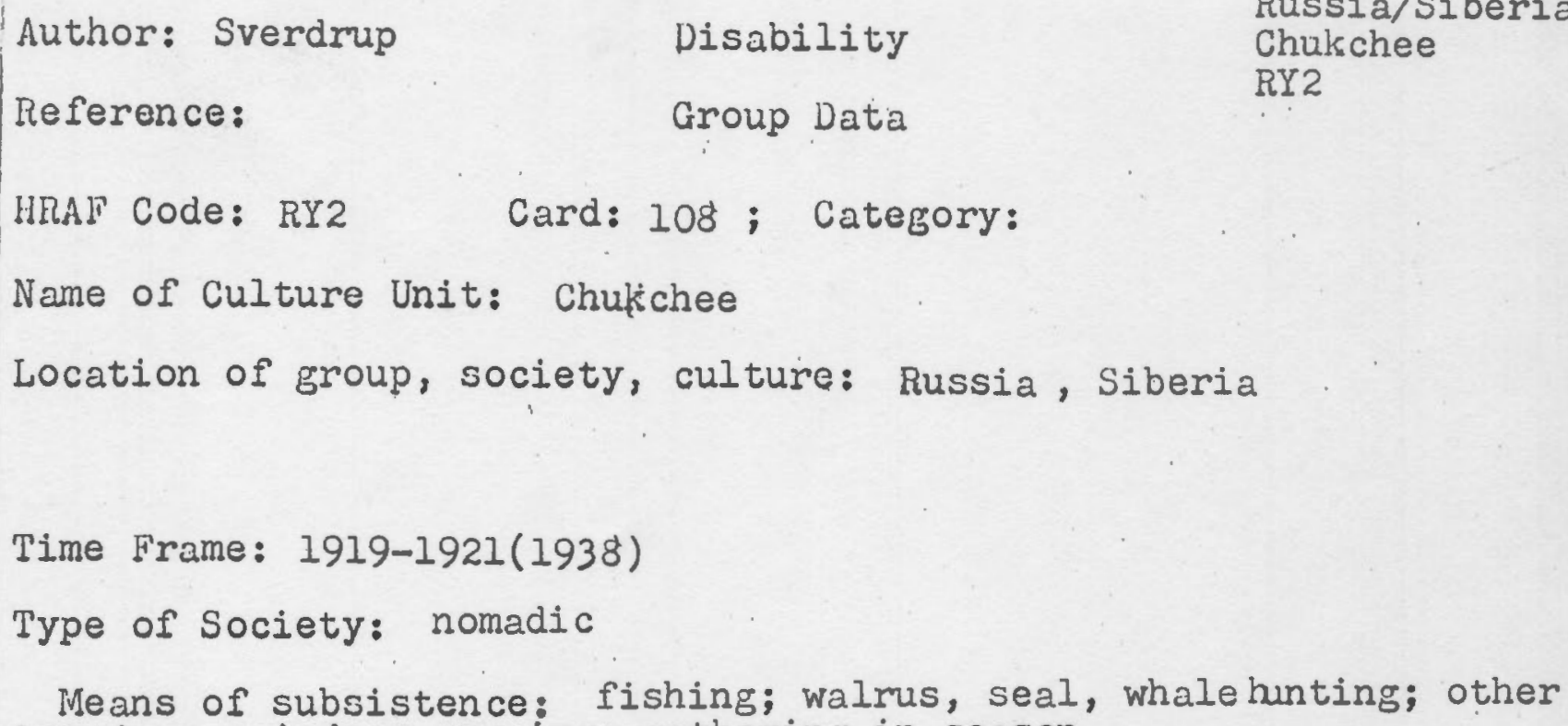

Number and type of disabled persons mentioned: general statement that "corralling reindeer was a risky business... and many a Chuckche $\epsilon$ has lost an eye." Thus blindness or partial blindness not uncommon. Special Attention to Disabled:

Positive:

Negative:

Other: 
HRAF Code: SB5 Card: 064; Category: 143

Name of Culture Unit: Cuna Indians

Location of group, society, culture: San Blas Islands and mountain dwelling cuna of interior. Island Indians have plańtations on mainland: obtain fresh water; cut cooking wood; shoot game; bury dead. Mountain and Island Indians appear to have same customs anc beliefs.

Time Frame: (1680-81) 1934

Type of Society:

Keans of subsistence: Hunting, gathering

Means of subsistence (disabled):

Number and type of disabled persons mentioned: Albinos form "...2 to 10 per cent of the population." Albinos do not see well in sun and are considered weak when compared to other cuna; not fit for hunting or other laborious exercise."

Special Attention to Disabled:

Positive: Interaction between albinos (white) and other Cuna.

Ablino girls allowed to marry.

Infanticide/senilcide: Disabled (albino) infants only in early times unless mother could hide infant for "some days;" (Mtn. Indians)

Negative: Infanticide. Brown Cuna did not respect white Indians as much as other Brown Indians, "looking on them as somewhat monstrous."

White male adults not allowed to marry. Albino males and female not allowed to marry. "Albino girls maymarry but not at all admired."

Other Wafer was a doctor who accompanied a Pirate, Dampier, in 1699. (Nordenskold: 418) 


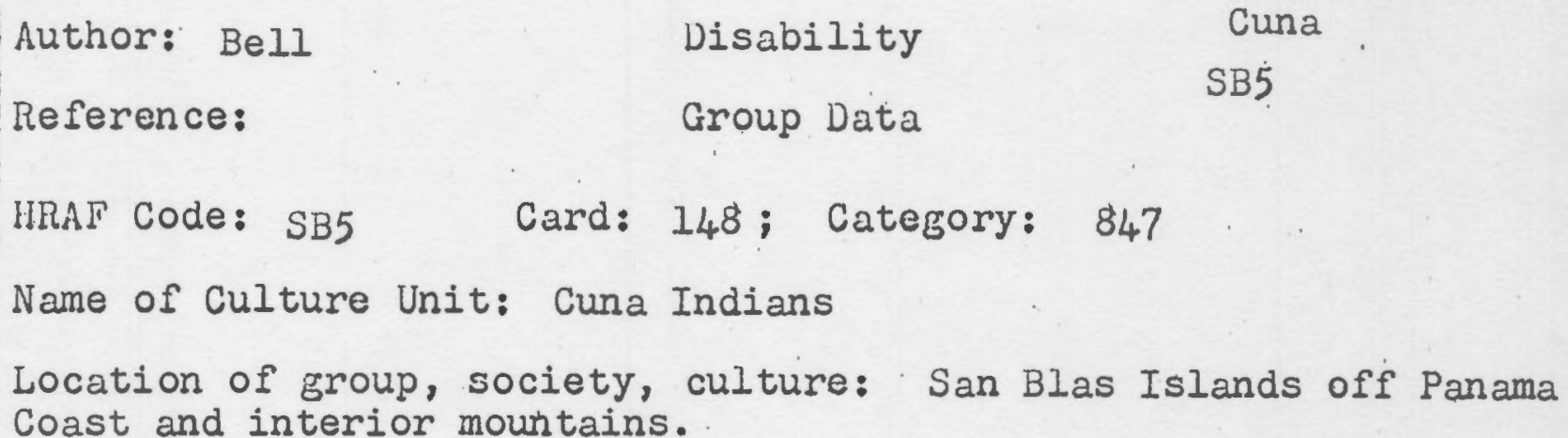

Time Frame: (no date) 1909--quotes early source [Lss: this section taken from Valdes Ramon, Geographia del istmo de Panama."

Type of Society:

Means of subsistence: -- Horticulture fishing, hunting.

Number and type of disabled persons mentioned: -- deformed infant and illegitimate children.

Special Attention to Disabled:

Positive:

Negative: Infanticide.

"'Children are buried alive or drowned if illegitimate; also those born deformed." (according to some writers)" "

Other: 
Author: Nordenskiold

Reference: pp. 417-421

HRAF Code: SB5 Card:
Disability

Group Data
South America

Cuna

SB5

Name of Culture Unit: Cuna Indians, but not all of them;

Location of group, society, culture: San Blas Islands and mountain interior; albinoes not along Rio Caimanes, East of Gulf of Uraba, or among Choco Indians." (p. 420)

Time Frame: (1927) 1938; author cites historial data

Type of Society: Fishing and horticulture and hunting.

Weans of subsistence: Fishing, agriculture, hunting

Number and type of disabled persons mentioned: Quotes Wafer, docto who accompanied Dampier (a pirate) in 1699. "estimated about one whi Indian to every ordinary Indian." (p.4l8) *Other defectives seldom seen: 1 blind man, 2 deaf mutes; 4 idiots. * (Nordenskiold:480)

Special Attention to Disabled:

Positive: Part of society and interacted with community if they survived infancy.

\section{survived infancy.}

In times

Negative: Early/infanticide of albino or deformed infants. (Nordenskiold: 418 )

Albinoes not allowed to marry (Nordenskiold: 420)

Explanation of Albinism: "The Cunas imagine a certain connection between the sun, the moon, and the white Indians...Wafer said (that)

Chief Lacenta said that "an Indian woman would bear a white child if if she looked at moon while pregnant.

Other: Nordenskiold stated that many more albino children may have been killed than noted because "to some extent among the Cunas they are regarded as children of evil spirits." (420)

*Three epilemtics (480) 
Author: Marshall

Reference:

HRAF Code: SB5 Card: 148 Category: $847,826,1,16,143$,
South America

Cuna

SB5

Name of Culture Unit: Cuna Indians

Location of group, society, culture: San Blas Islands and mountain dwelling Cuna of interior.

Time Frame: (1940) 1950,

Type of Society: Means of Subsistence: Horticulture fishing, and hunting.

Number and/or Type of disabled persons: Albinos, significant percentage of population.

Means of subsistence of disabled: Albinos not able to perform hard labor but "at night are able fishermen." (card 065:143)

Spexial Attention to Disabled:

Positive: "At inter-island conference...albino councilmen frequently entered discussion and enjoyed same confidence as other Indian spoksmer (category 826);"albino accorded special place in tribal ititual life; oc cupy high place in many councils; some becoming chiefs or even Neles;" (categories: 116,143); albinos thought tohave special place in heaven and are special charges of God; brown Indians need to associate with a binos on earth to have same home in heaven.*

Negative: Infanticide still practiced, but less prevalent than in seventeenth century and may be due to Christian influences.

Albinos not considered good workers; they suffer marriage, restrictio:

General Infänticide/Senilcide: Illegitimate children.

Infanticide/senilicide (disabled only): . Practiced in past; less prevelant in 20th century.

* Special status in heaven counteracts the effect that albinos are not good workers and do not marry.

Comments: "There are medicines for preventing or producing albino birthe"from Shamans.

Other *albino children not given as hard tasks as brown children in family, but they are"considered to be of superior intelligence." 
Author: 3: Brettion

Reference:

HRAF Code: SC7

Card: 050

Name of Culture Unit.

Location of group; society, culture:

Time Frame: (1891-1895).1903-Brette): Bolender: (1914-1915) 1925

Type of Society: Means of Subsistence: hunting and gathering

Number and/or Type of disabled persons: numbers not mentioned

Types: aged infirm/sick

Spexial Attention to Disabled:

Positive:

Negative:

General Infinticide/Senilcide: In the past the aged infirm were put to death.

Infanticide/senilicide (disabled only): (Brettes: "at the present time infirm old people are treated with indifference, as are all sick people, They are not put to death any more."(330 contd)

(Boldender) "Burying sick or old people alive is not regarded as a cr nor is suicide." ( 114 contd)

Bolender: "Burying sick or "9ld people plive is not regarded as a crime
Disability

Group Data
South Amẹrica

SC7 
¡Author: 1: Reichell-Dolmatoff Disability Reference:

Group Data

HRAF Code: SC7 Card: 88z Category: 847, 158

South Ameriça SC7 Cagaba:

Name of Culture Unit: Cagaba, Kogi

Location of group, society, culture:

Time Frame: (1946-49) 1949-1950

Type of Society: Means of Subsistence: Hunting and gathering

Number and/or Type of disabled persons: No numbers cited

Types; aged infirm or sick and infants (well or not)

Sperial Attention to Disabled:

Positive:

Negative: infanticide/senilicide practiced

General Infanticide/Senilcide: Yes

Infanticide/senilicide (disabled only): Yes, probably (not specifically stated) $(267-268)(145)$

"Infanticide is emphatically prohibited, but it occurs at times in a "disguised farm when a mother 'sticks' a baby while it is sleeping." "The rule according to which babies ought to sleep apart from their mothers seems rather to be to protect children against this form of* Coments: (1) "T never encountered madmen or idiots in Arthouaque territory." (1349 cont'd)

*infanticide (mothers'flatten'babies during sleep. (/167/ cont)

Other 
Author: La Barre, Weston

Disability

Group Data

Reference: "The Aymara South America. SE5 Indians of the Lake Titaca Plateau, Boliviar" in: HRAF Code: SF5 Card: Category:

Name of Culture Unit: Aymara Indians

Location of group, society, culture: Deparmentos (or "states") of La Paz, Urura and Cochabamba, centered abdut Lake Titica, on Boliviar Time Frame: altoplano.

Trme November 1937-illay 1938 .

Horticulturalists;

Type of Society: Means of Subsistence: Bulk of food, vegetable stuf mainstay is potato rather than corn; Animal husbandry and agriculture Number and/or Type of disabled persons:

1900 census showed: 15 blind persons per thousand population, 14.1 I 8 insane, 6.5 one-armed, 11.8 mute, 10.1 deaf, 3.1 deaf-mute, 11.4 oneeyed, 5.8 with the loss of the use of a member, and 14.2 with othar infirmities are traumatic and indicative of the physically violent life which the Aymara lead; other... infirmities originated in diseases."(46)

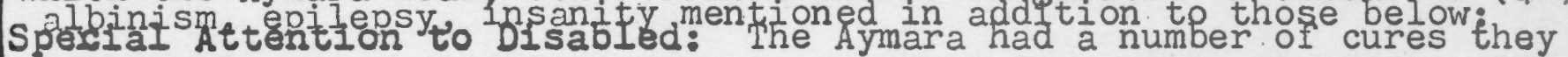
have developed; medicine, meteorology, other factors involved.

Positive: The Aymara are concermed about their health; have a highl 1) medical vocabulary with names for the blind, deaf, mute, lame, one-eyec one-armed, armless or handless, harelipped (which is very common), hunc. backed, dwarfs, and hands or feet with too many digits, which indicates that the Aymara know something about their bodies. (46)

2) Aymara try tol cure individual according to their own beliefs,knowledge

Negative: Aymaras believe in witchraft; believe that disease is caus by "evil machinations."(214) Several methods of divination used to ric persons of evil spirits.(220)

In early times the Aymara may have sacrificed children "in order to $t a$ omens in the time of war. "(.173)

General Infanticide/Senilcide: Yes, twins, especially if male and female, are allowed to die because they bring "bad luck on house."(120)

Infanticide/senilicide (disabled only): Abortion is mentioned but infanticide; however, the Aymara have a name for. "Any unusual or monstr birth (d.g., harelip, syndactyly, polydactyly) is called waka."(120)

Forbes, an earlier anthropologist, is cited by the author saying that t] infants who are not strong do not survive because their life is so hars. thus only the sturdy survivors are left. (126)

\section{Coments:}

1) "Wen children or babies have white hair (?albinism) the Aymara say it "beloved of the Lord."(123)

2) Practice of trephining may have been used as a cure for epilepsy as wel 3) The Aymaras use "inymphaea alba" (a plant) to cure.epilepsy and hysteria. pther

4) Aymara probably do practice senilicide; "respect old age considerab and the oldest man is often consulted, feared and obeyed." but, "It is known that the Indians...occasionally put an end to the sufferings of $t$ relatives, when about to die, by strangling them with a rope, under the impression that by doing so they can prevent the ghost of the deceased turning to this world to haunt and trouble them."(135)

At the time of the studity there was still a lot of smallpox, scarlet fever and "is greatly feared by the Indians since, in addition to the treat mortality rate, it also often leaves, them blind, with twisted li and otherwise incapacitated." (48) 
Author: 1: T'schopils Reference :

HRAF Code: SF5 Card: 066 Category: 847

Name of Culture Unit:

Location of group, society, culture: Bolivian and Peruvian Altoplanc
around Lake Titaca Time Frame: (1940-1942).1946

Type of Society: Means of Subsistence: Horticulturalists, ing, fishing, Number and/or Type of disabled persons: numbers not citèd.

\section{Spexial Attention to Disabled:}

Positive:

Negative:

General Infanticide/Senilcide: Probably, sometimes. Infanticide/senilicide (disabled only): Deformed babies, yes. $(548)$ (1) is not approved, but deformed babies are allowed to die." ". revent the deliberate murder of mortality serves effectively to public knowledge." ( comments:

Explanation for disability:

Other"If the mother visits cemeteries, particularly ancient burials, or handles human bones, the child will be deformed." (548) 
;Author: 4: Nino

Reference:

HRAF Code: SF5 Card: 051 Category: 732

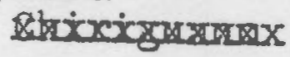

Name of Culture Unit: Aym ara

Location of group; society, culture:

Time Frame: (1893-1911) 1912

Type of Society: Means of Subsistence: agriculture, hunting, gather.

Number and/or Type of disabled persons: numbers not cited.

Types: defective children

aged infirm

seriously.ill. (the same yardstick for treatment could be applied to persons who are disabled and dependent)

Special Attention to Disabled:

Positive:

Negative:

General Infäticide/Senilcide:

Infanticide/senilicide (disabled only): "They kill their defective children, and, as a philanthropical act, those who are sick with prolonged illnesses and the old who are fatally ill are buried alive so that they may not suffer so much.'(I)( 318 cont)

Comments:

other 
$\begin{array}{lll}\text { Author: 12: } & \text { Buechier and Disability } \\ \text { Buechler } & \text { Group Data } & \text { SF5 Amerioa }\end{array}$ Roference: HRAF Code: SF5 Card: Category: 732 Aymara

Name of Culture Unit: Aymara

Location of group; society, culture:

Time Frame:

Type of Society: Means of Subsistence:

Number and/or Type of disabled persons: Numbers not cited. deformed infants

Spexial Attention to Disabled:

Positive: "Ambivalent attitudes mark the birth of deformed infants as well (as those of twins). The following deformations were related to us: children with six toes or fingers (pulu pulu), webbed fingers (karachi), birth marks, children borm with eyes open, deformed legs. and arms, club feet. These children are said to be "beloved of God" That is perhaps the reason why they are asked to intercede at the aton ment ceremony of the twins." Negative:

General Infanticide/Senillcide:

Infanticide/senilicide (disabled only):

Comments:

Other 


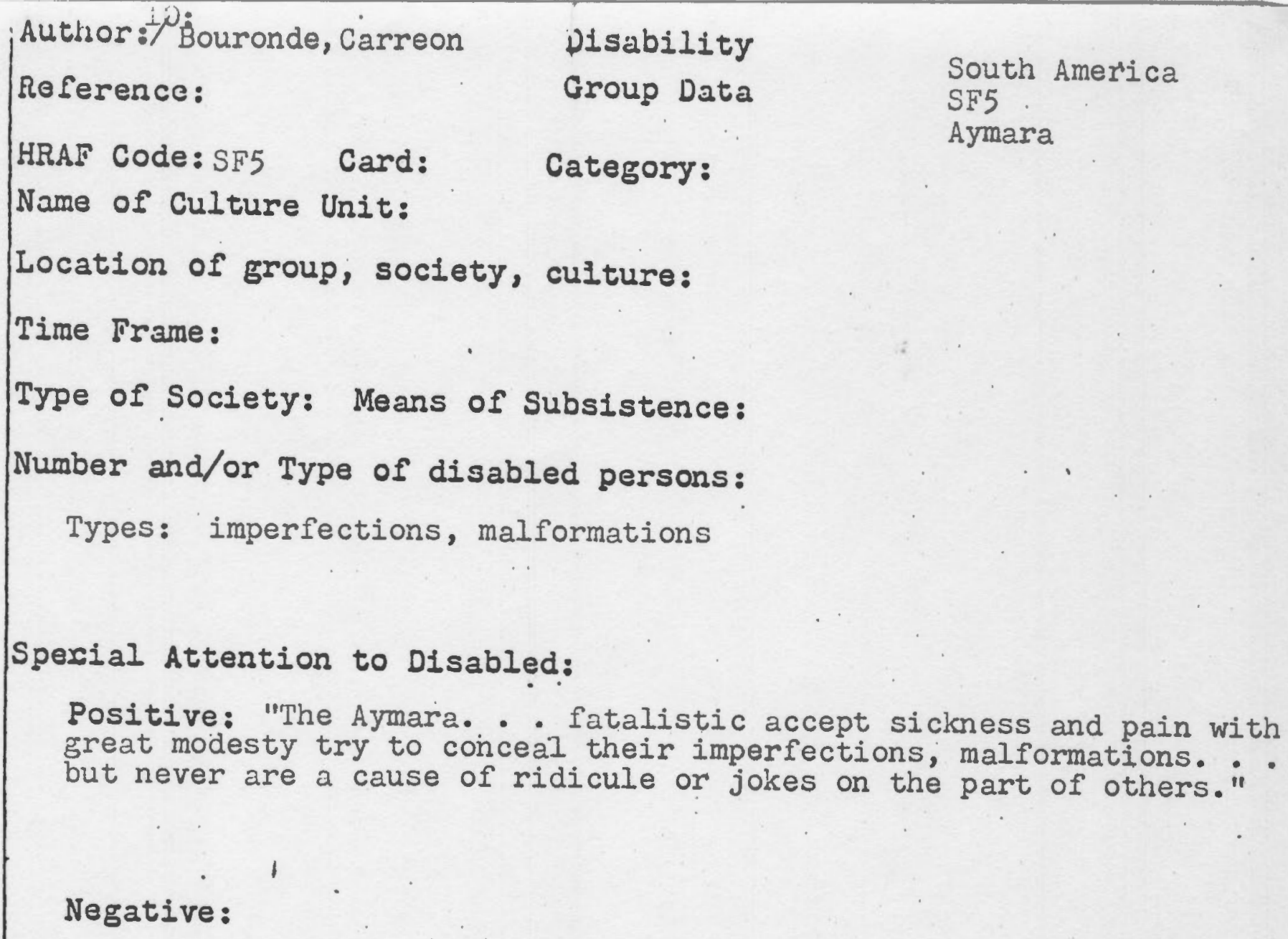

Sperial Attention to Disabled:

Positive: "The Aymara. - fatalistic accept sickness and pain with great modesty try to conceal their imperfections, malformations. . but never are a cause of ridicule or jokes on the part of others."

Negative:

General Infäticide/Senilcide: Infanticide/senilicide (disabled only):

Comments:

bther 


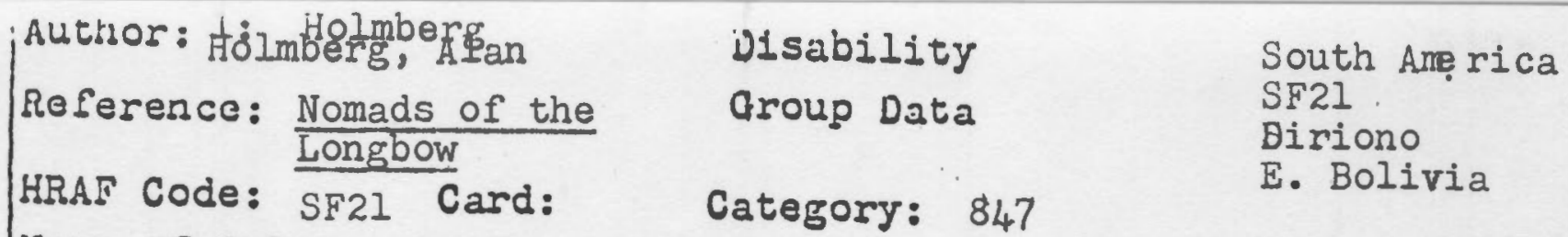

Name of Culture Unit: Siriono

Location of group, society, culture: E. Bolivia

Time Frame: July 15, 1941 to March 1942, excepting occasional returns to the outside world for medical care or "refreshing author's mental Type of Society: Means of Subsistence: Hunters and gatherers stat $\epsilon$ Number and/or Type some cultivation

1) lation had club feet. $(9)$ Number - about $15 \%$ of popu-

2) deformed infants

3) a cripple, Ekwataia (260)

4) aged infirm (225)

Spexial Attention to Disabled:

Positive: "Even clubfooted children and other deformed infants are shown no lack of partiality in this respect." (202) (fondling infants)

Negative: "When a person becomes too ill or infirm to follow the fortunes of the band, he is abandoned to shift for himself.) (225)

General Infanticide/Senilcide: ". . other offenses against life, abortion, infanticide seem to be unknown."

Infanticide/senilicide (disabled only):

Comments: Explanations of disability: "Anteater causes clubfootedness" if eaten by any except the old. (206) Porcupine also believed to cause clubfootedness. (213)

Evil spirits, abacikwaia "enter the mouth or nose when a person is sleep (especially when he is snoring) and settle in the regions where the pain is felt. (227)

pther 


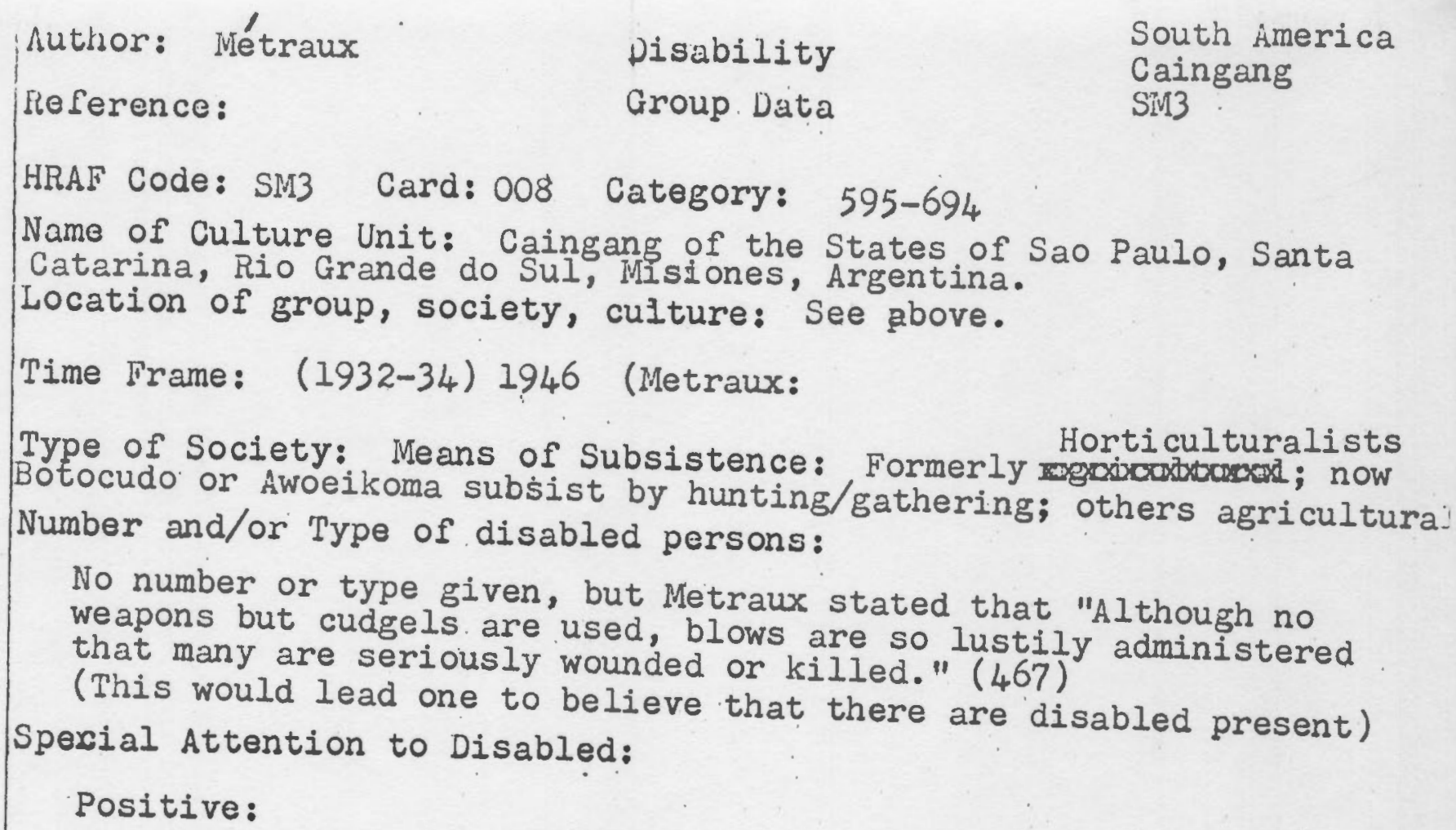

Type of Society: Means of Subsistence: Horticulturalists Botocudo or Awoeikoma subsist by hunting/Formerly mowixom Number and/or Type of disabled persons:

No number or type

weapons but cudgels are used Metraux stated that "Although no

that many are seriously wounded

(This would lead ously wounded or killed." (467)

Sperial Attention to Disabled:

Positive:

Negative:

General Infénticide/Senilcide:

Infanticide/senilicide (disabled only):

Comments:

pther 


$\begin{array}{lll}\text { Autior: Henry } & \text { Disability } & \text { South America } \\ \text { hoference: } & \text { Camgang-Aweikoma }\end{array}$

HRAF Code: SM3 Card: OlO Category: $888^{\circ}$

Name of Culture Unit: Caingang-Aweikoma

Location of group, society, culture: State of Santa Catarina, Brazil Time Frame: (1932-34) 1941

Type of Society: Means of Subsistence: Nomads/hunters and gatherers

Number and/or Type of disabled persons: No number given;aged infirm noted. "...Kaingang were handicapped by those who too old to move about easily...carried them on their backs both men and women when they could not walk or walked too slowly... Few of Kaingarg lived to a ripe old age ...but when they did they were cherished to the last." (2) man with only one arm mentioned.

Special Attention to Disabled:

Positive: Carried aged infirm on backs when the elderly were unable to walk or to walk fast enough.

Allowed man with one arm to become a Quati (a type of Shaman)

Negative: In extreme instances the Caingang probably left the aged infirm behind when they moved on. (116)

General Infanticide/Senilcide: Probably practiced both in extreme situations; but no mention of infanticide. Infanticide/senilicide (disabled only):

Explanations for Disability: Loss of arm attributed to his "refusal of power from Snake, who therefore bit him in anger." (77) Comments:

Other 
;Author: Chagnon

Disability

Group Data
South America.

SQ18

Yanomamó

Reference: Yanomamo, The Fierce People

\section{HRAF Code: SQ18 Card: Category:}

Name of Culture Unit: Yanomomo

Location of group, society, culture: Southern Venezuela and adjacent portions of northern Brazil

Time Frame: 1964, later field trip 1975

Type of Society: Means of Subsistence: Hunting, gathering, fishing, cultivation of gardens slash/burn agriculture ( 1 , ' Number and/or Type of disabled persons: / Numbers and types lez ( 20 ) However, society is so violent that there must be injured/disabled persons, if from no other cause.

"unother man chopped his wife on the arm with a machete; the missionaries in that village feared that the woman. would lose the use of her hAnd because 3 gime of the tendons to her fingers were severed."(83)

Sperial Attention to Disabled:

loss of limb (20) ( 30 years old)

Positive: "When sickness is deemed to be the result of soul loss, $t$ people who are closely related to the sick person hunt for his noreshi. (The Yanomamo are trying to help the disabled person in their way.)

\section{Negative:}

General Infanticide/Senilcide: Yes, especially female infanticide. (74) "A child is killed at birth, irrespective of its sex, if the mothe Infanticide/senilicide (disabled only): already has a nursing bab. $(74)(75)$

Little mention jis made of age; "A woman gains a measure of respect wi she becomes old. By then she has adult children who care for her and treat her kindly. ( 83 )

Senili cide (?)

\section{Comments:}

"The Yanomomo do not employ medicines made from plants or animals. . . they rely exclusively on the cures that the shabori effect, fighting supernatural ills with supernatural medicine." (52)

But 12Two percent of all adult deaths are due to snake bite; 54 percent due to malaria, and other epidemic diseases (Chagnon 1966)' and 24 perce other of adult males die in warfare."(20n)

(Some of the persons who have diseases or are injured are left with per maent disabilties) What happens to them?

Loss of limb: Limb lost from snakebite when about 15 yrs. old and "w. spend the rest of his life hopping on one leg, a form of locomotion $h$ has mastered so thoroughly the he almost manages to keep up with the group when they visit other villages." (20) 
Author: Embree, John I. Reference: Suye Mura
Disability

Data on Individual
Asia

Japan

$A B$

Kyushu Island

HRAF Code: Card: Category:

Name of Culture Unit: Village of Suye Mura

Location of Group, Society, Culture: Suye Mura Village, Kuma County, Japan.

Time Frame: c. 1940's

Individual: Name or description: Blind Kitoshi in Suye, "most popular and influential one." He tended the Tendai temple in Oade.

Type of Disability: Blind

Age Disability Acquired: Not known.

Status and Role: The blind Kitoshi belonged to the Tendai sect, which combined Shinto and Buddhist elements; he was a priest.

Position in Family: Father

Dependent:

Independent: "The blind priest is so busy at his business that he follows no other occupation." Other priests served as farmers, etc (190)

Infanticide/Senilcide-General-practically none. (134) Infanticide/senilcide (disabled only): Evidently not.

Comments: Embree refers to custom where the temple in which the bli Kitoshi served was one of ten from an original sixteen and was said $t$ be 300 years old. "Formerly these temples had blind priests, but mor recently seeing priests had come in. "(189) This infers that theze ma: have been more blind persons in the past.

Other: 
Author: Embree, John F.

Reference: Japanese $\frac{\text { Dillage Suye Mura }}{\text { Via }}$

\section{HRAF Code: Card: Category:}

Name of Culture Unit: Village of Suye Mura

Location of Group, Society, Culture: Suye Mura Village, Kuma County, Japan.

Time Frame: c. 1940:ss

Individual: Name or description: "One deaf and dumb woman. .."(12

Type of Disability: Deaf and dumb

Age Disability Acquired: Not known; probably at birth.

Status and Role; Widow and housekeeper.

Position in Family: Widow two times (she had two successive husbanc

Dependent:

Independent: ". . mins her household remarkably well."(129)

"Attends all buraka functions, and talks to her friends by means of graphic signs. She even dances at the drinking parties.

Infanticide/senilcide (disabled only): Not practiced. (134)

Comments:

Other: 
Author: Embree, John F.

Reference: Japanese Villagobata on Individual
Asia

Japan. () (is $\because$ :

$A B$

Kyushu Island

\section{HRAF Code: Card: Category:}

Name of Culture Unit: Village of Suye Mura

Location of Group, Society, Culture: Suye Mura Village, Kuma County Japan.

Time Frame: c. 1940's

Individual: Name or description: "A feebleminded boy more handicapp by blindness than a weak mind." (129)

Type of Disability: blind (the author leaves some doubt as to the extent of the boy's feeblemindedness.

Age Disability Acquired:

Status and Role; son in household and permanent nursemaid

Position in Fumily: son

not totally

Dependent: Probably/dependent on family, but able to take care of babies or children.

Independent: Independent to the extent that he could be useful to the household.

Infanticide/senilcide (disabled only): Evidently not. (134)

Comments:

Other: 
Author: 2: Wiser and Wiser Heference :
Disability

Data on Individual
Asia India Uttar Pradesh i i

HRAF Code: AW19 Card: O10 Category: 732

Name of Culture Unit: Village of Karimpur

Location of Group, Society, Culture: United Provinces

Time Frame: (c. 1925-1930) 1930

Individual: Name or description: "Shanti," living living just acros the road Irom our camp, in the outcase section of the village." (120)

Type of Disability: blind from_smallpox

Age Disability Acquired: Sometime during childhood.

Status and Role: Daughter, attends Missionary School; engaged to man who turned out to be a thief

Position in Fimily: Daughter prospective bride

Dependent: Yes

Independent:

Infanticide/senilcide (disabled only): no mention

Comments: The missionaries made arrangements for Shanti to attend school for the blind, but her parents would not let her go, first ge"Her mother will cry if she has to p'art with her," and secondly, because parents feared that they would lose opportunity to marry Shanti if she was away at school.

Other: 
Author: Griaule, Marcel

Reference: Conversations with Ogotemmele. •

\section{HRAF Code: FAl6 Card: Category:}

Name of Culture Unit: Dogon Country, Lower Ogol, West Africa

Location of group, society, culture: same as above

Time Frame: 1946

Individual: Ogotemmêle

Name or Description: Ogotemmêle, "a venerable individual. . This man, a hunter who had lost his sight by an accident, was able, as a result of his infipmity to devote long and careful study to these things,

(cosme of bisability: Blind adult

Age Disability Required: As an adult, he became totally blind, but he had lost the sight in one eye in childhood from smallpox. (15) Having only one eye had not prevented him from being an expert hunter. Status and Role: Dogon elder.

Position in liamily: Father of 21 children.

Dependent: Probably for food, but he had a family and they probably took care of his needs.

Independent: Intellectually and probably economically

Means of Subsistence: Ogotemmêle did not have to work like ordinary men because hi. occuppied such a high status in his community and country.

*Endowed with exceptional intelligence, a physical capacity which was still apparent despite his affliction, and a wisdom, the fame fame of which has spread throughout his coutry. (2)

"His skill as a hunter was the fruit of his profound knowledge of nature, of animals, of men and of gods. After his accident he

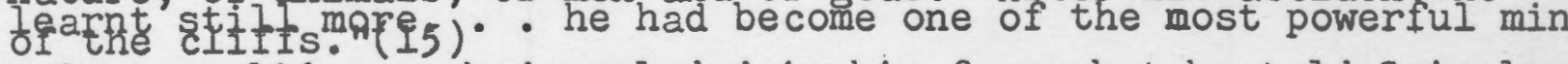
Other: Ogotemmeli's gun had exploded in his face, but he told Griaule that although losing his sight was an "accident," "But it was also a last warning. I knew by divination that I was to give up hunting if I wanted to protect my children. Hunting is a work of death, and it attracts death. I have had twenty-one children, and now only five are left."(14) 


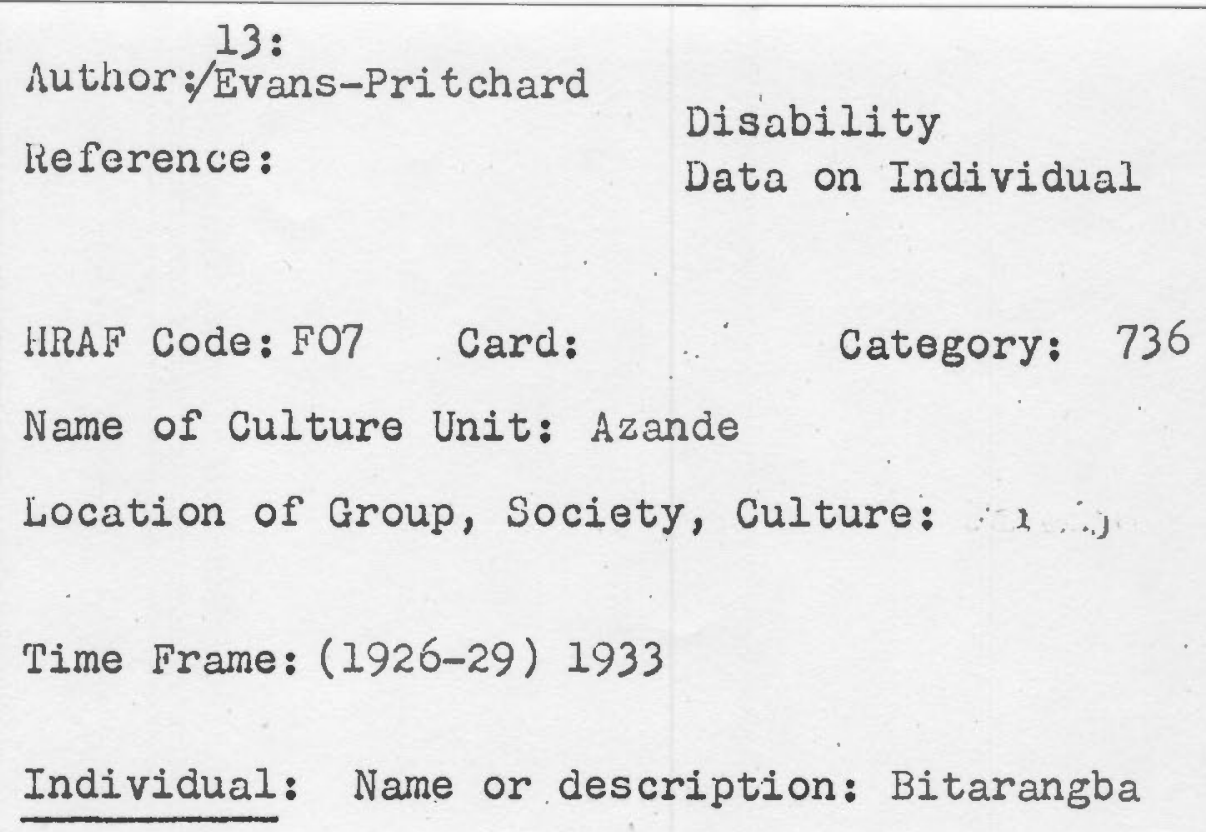

Type of Disability: Hands and genitals cut off.

\title{
Individual: Name or description: Bitarangba
}

\begin{abstract}
Age Disability Acquired: As an adult
\end{abstract}
Status and Fole; Blood brother with "two or three influential men of the neighborhood. . .".

Position in Family: "He was not on good terms with his relatives."

Dependent: Yes, but not completely. "He lived with one of his blo brothers, whose food he ate and whose household he assisted by making nets and by snaring guinea-fowl. Besides this man, whose home he shared Bitarangha had exchanged blooe with several other neighbours*

* and was always a welcome guest at their meals. Being physically help less he made a point of contracting alliances of blood with 2-3 influential men. . who were able to assist him through their influence at Infanticide/senilcide (disabled only): court andtheir authority in

Comments:

Other: 
Author: 20: Czekanowski

Reference:

HRAF Code: FO7 Card: Category: 752

Name of Culture Unit: Azande

Location of Group, Society, Culture: "in Faradje, (author photograph Babandara)

Time Frame: (1907-08) 1924

Individual: Name or description: Babandara, (son of Delaw) who had to atone bitterly for seducing a wife of Sanango's.

Type of Disability: Mutilated. "The unfortunate man was mutilate by Sanango, (son of Ngerria) who lives along the Gada, a tributary of the Duru. He had lost his genitals and both hands. His testicles haci been cut off, as well as his penis, and only a raw scar was left."

Age Disability Acquired: As an adult.

Status and role;

Position in Family:

Dependent:

Independent:

Infanticide/senilcide (disabled only):

Comments:

Other: 
Author: Crowley, Daniel J.

Reference: in: d'Azevedo, Disability
Warren. The Traditional

Artist in African Societies;

letter from Crowley, 6-19-84

HRAF Code: Card: Category:

Name of Culture Unit Katanga Chokwe

Village of Chokolatwe probably in Alto Zambeze Province; later Zaire and Congo.

Location of Group, Society, Culture: see above

Time Frame:

Individual: Name or description: "Kawina Limema, he was a younger lombo's village. . "(letter)

Type of Disability: "He walked with both knees slightly bent and legs stiff, possibly from in injury."(letter)

Age Disability Acquired: ?

Jusband Father of 2 childre

Status and Role: Kawina Limema. . . Was in every way a full member of the community. A carver under tutelage of Sanjolombo

Position in Fumily: Kawina Liwema lived in Sanjolombo's village, since villages are family affairs in Zaire, and he carved, helped Sar jolombo in the fields. . ." (letter)

Dependent: no

Independent: yes;"... even though he couldn't do stoop labor or hard harvesting. Remember women do the planting and weeiling and most harvesting there... "Iñ that line, Liwema was able to do almost everything needed." (letter)

Infanticide/senilcide (disabled only):

Comments:

Other: 
Author: Evans, Meryle

lieference: New York Times Data on Individual

FVl-Botswana

HRAF Code: FX18-Maun

Name of Culture Unit: Maun, Botswana

Location of Group, Society, Culture: Maun, Botswana, Safari lodge: San-ta-wani on the Okovanggo River in the middle of/thouth Central African Country.

Time Frame: 1984

Individual: Name or description: "Witness", a native of the area, who is a blind gardner for the safari lodge

Type of Disability: Blind

Age Disability Acquired: Born with.

Status and Role: Gardner

Position in Family: not known

Dependent:

Independent: works as gardner. "Walking barefoot, Witness counts the number of steps between the rows of cucumbers, eggplants, cabbage and beans he has planted. He can point out each variety, and by gent touching the tops of the plants he knows when to pull up carrots and onions.

Infanticide/senilcide (disabled only):

Comments:

Other: 
Author: Evans, Meryle

Reference: New York Times Data on Individual

$8-15-84$

FVI-Botswana

HRAF Code: FXI8-iHaun Card:

Name of Culture Unit: Maun, Botswana

Location of Group, Society, Culture: Maun, Botswana, Safari lodge: San-ta-wani on the Okovanggo River in the middle of/thouth Central

African Country.

Time Frame: 1984

Individual: Name or description: "Witness", a native of the area, who is a blind gardner for the safari lodge

Type of Disability: Blind

Age Disability Acquired: Born with.

Status and Role; Gardner

Position in Family: not known

Dependent:

Independent: works as gardner. "Walking barefoot, Witness counts the number of steps between the rows of cucumbers, eggplants, cabbages and beans he has planted. He can point out each variety, and by gentl touching the tops of the plants he knows when to pull up carrots and onions.

Infanticide/senilcide (disabled only):

Comments:

Other: 
huthor: Evans, Meryle

Reference: New York Times Data on Individual

$8-15-84$

FVI-Botswana

HRAF Code: FXI8-IVaun Card:

Name of Culture Unit: Maun, Botswana

Location of Group, Society, Culture: Maun, Botswana, Safari lodge:

San-ta-wani on the Okovanggo River in the middle of/thisth Central

African Country.

Time Frame: 1984

Individual: Name or description: "Witness", a native of the area, who is a blind gardner for the safari lodge

Type of Disability: Blind

Age Disability Acquired: Born with.

Status and Fole: Gardner

Position in Family: not known

Dependent:

Independent: works as gardner. "Walking barefoot, Witness counts the number of steps between the rows of cucumbers, eggplants, cabbages and beans he has planted. He can point out each variety, and by gent. touching the tops of the plants he knows when to pull up carrots and onions.

Infanticide/senilcide (disabled only):

Comments:

Other: 


\section{¿ Botswana, Recipes From Rochester}

\section{BY MERYLE EVANS}

Maun, Bolswana $\mathrm{ACH}$ evening at 8 a rhythmic drum roll summons guests to dinner at San-ta-wani, a small safari lodge on the Okovanggo 5 River in the middle of this south-central an country. As the drums beat the candles are d $d$ in the boma, a round, roofless enclosure of tightly woven reeds, high enough to disge an inquisitive giraffe from peering over at rnicircle of tables arranged around a crack. re.

en the diners have taken their seats under a iy of brilliant stars, two waitresses of the wana tribe from a nearby village serve bowls aming mushroom soup and pass thick slices igrant freshly baked white and whole-wheat 1. At a sideboard across the boma, Bruce $r$ carves a succulent roast leg of lamb and "Come on up and bring your napkins - the " are hotl" There is mint sauce and gravy, an ment of fresh vegetables - braised yams, , baked stuffed summer squash - and tossed with crisp lettuce and ripe tomatoes.

ar culinary surprises await guests at this.deul outpost in the wilderness, but the biggest se of all is the cook: a young American from ster. How did Nanette Ebersol, a soft-spoken $y$-psychology major at the University of ster come to San-ta-wani? And how did she 10 cope with such problems as marauding tys and temperamental gas generators? Corps training is the answer.

ver since high school," the 25-year-old Miss iol explained, "I had wanted to join the corps, ipplied and was accepted during my senior it college." Assigned to a school in the mining uf Lobatsi, Botswana, she taught mathematid science to 55 students aged 12 to 23 . Virtuu scientific equipment was available, only a voard, so she made do with ingenuity and pernce and was awarded a coveted commenda" December 1983, at the end of the two-year am.

ing a Christmas vacation, when Miss Eber. varents, two sisters and brother came for a the family spent a week in Botswana's vast, 'led wildlife reserves. Their photographic savas arranged by Gametrackers International, jortium of local companies and the Botswana nment, which operates four camps in remote Miss Ebersol loved the atmosphere at the $\mathrm{s}$, so, after completing her stint in the Peace she applied to Gametrackers for a job and ffered that of caterer-housekeeper at San-ta"I had never had the least interest in cookshe acknowledges, "but I came from a y of excellent cooks." Soon letters were flying and forth between Botswana and Rochester equests for favorite recipes and replies from uther, Rita Ebersol.

re was also on-the-spot assistance from Wita native of the area, who, though blind since tends a flourishing vegetable garden behind tchen. Walking barefoot, Witness counts the or of steps between the rows of cucumbers, ints, cabbages and beans he has planted. He int out each variety, and by gently touching is of the plants he knows when to pull up carad onions. His garden, protected by a strong from the hippopotamuses that lumber in San-ta-wani at night, supplies all the

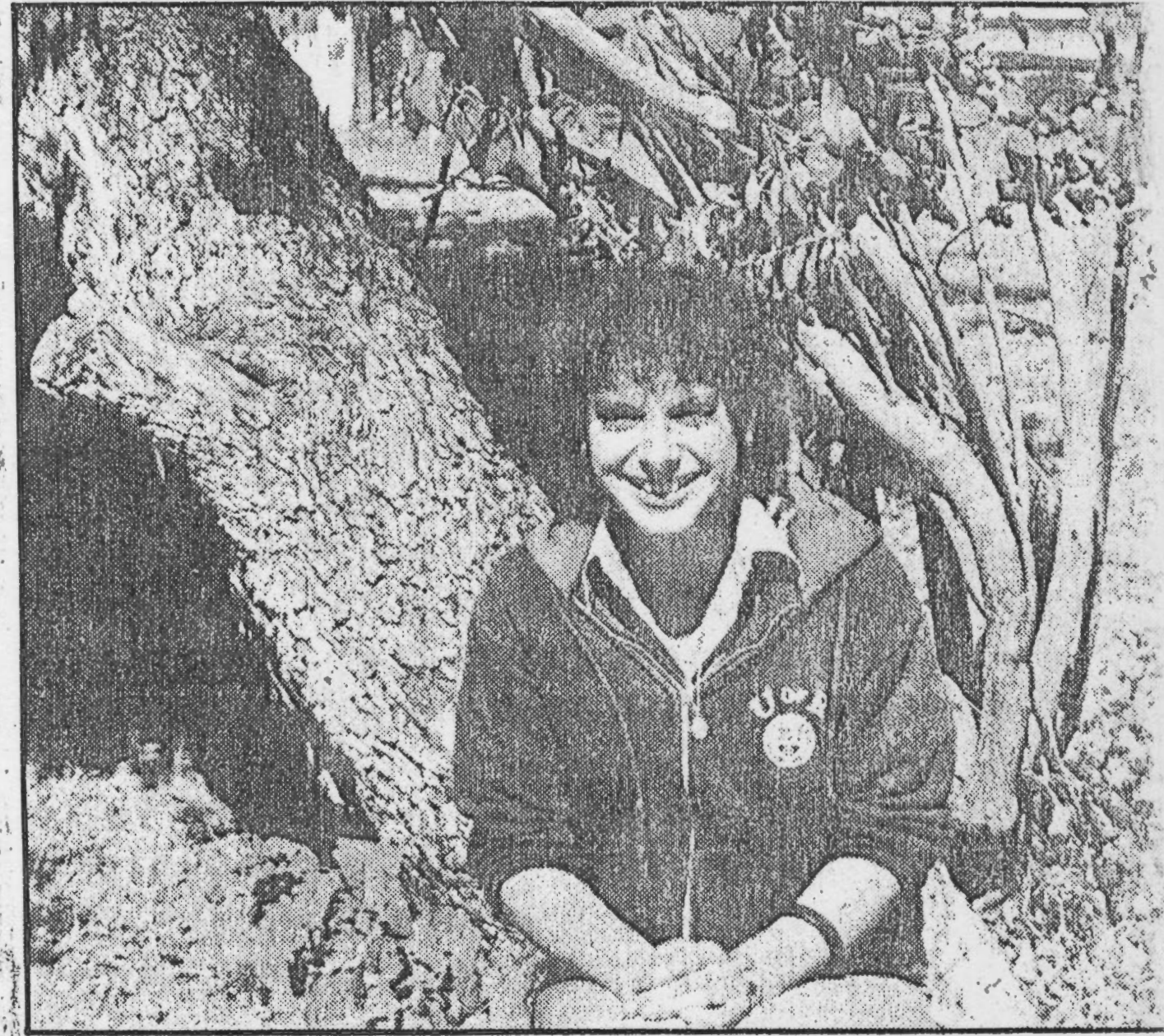

Nanette Ebersol is caterer-housekeeper at an African game lodge.

Culinary surprises prepared deep in

\section{Africa by a former Peace Corps aide.}

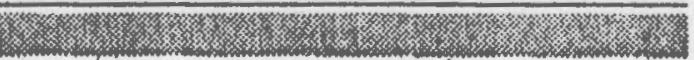

Gametracker camps with fresh produce.

Like other perishables, including eggs and the Stilton, Camembert and cheddar servea for dessert at lunch, the vegetables are transported (when there is space) in the single-engine Cessna that flies guests to the camps. Haphazard airborne deliveries are a minor inconvenience for Miss Ebersol. The havoc wrought by hungry hyenas is more of an annoyance. Each dawn she checks to see if the night prowlers have attacked the garbage cans or chewed up the upholstery in the lounge Then the stove is lighted for wake-up tea and culfe: sent to the cottages at 7 .

Half an hour later a dozen guests and staff men. bers with huge appetites plow through a breakfas of papaya, cold cereal and hot porridge, cousits sausage, thick slices of bacon, scrambled egt and, perhaps, corn fritters or broiled tomatocs; Then everyone is off for the morning game drive, bouncing around the bush in Land-Rovers or pac dling canoes through the winding Okovangg: waterways, while the caterer-housekeeper stay: behind to supervise the staff, plan meals and cliecl supplies. Culinary. staples are brought by trucl from Maun, a 70-mile trip over rough dirt roads.

Some fresh chickens arrive, and when the guest return at 1 P.M. there is chicken stew with cor. and peppers, shrculded carrut salad and coleslaw tossed with pineapple cubes. There is also a great deal of aninated table conversation - a Texi drawl mixing with German and New York acces and clipped New Zealand English - as the grou, discusses the herds of zobra, mating lions, os triclies and crocodiles seen lazing in the sum.

After lunch everyone - even the staff - has nap. But by teatime Miss Ebersul has baked batch of raisin cookies. They disappear as quicki at Sall-ta-wani as they would in the family kitclse in Kochester. 
Author: Marshall; Lorna

Reference:

The !Kung of Nyae Nyae

Disability

Data on Individual

AFrica

Bushmen .",

FXI0

\section{HRAF Code: FXIO Card: Category:}

Name of Culture Unit: !Kung of Nyae Nyae

Location of Group, Society, Culture: Nyae Nyae area, Kalahari Dese

Time Frame: c. 1976 (probably 1952-53)(187); 1961(187)

Individual: Name or description: !Kham

Type of Disability: IKham crippled by a bone disease. (186)

"Both legs withered. !Kham propelled himself by lifting himself

by his hands, holding on to two forked sticks taller than himself, and swinging his whole body forward between his sticks."(187)

Age Disability Acquired:

"as a young man" (186)

Status and Role: Husband and father of four children; but they hac few relatives, "if not utterly unattached, was on edge of being so Position in ramily: Husband and father of four children.

Dependent: !Kham could not hunt; his wife Be, "the smallest of the !Kung women. - gathered for !Kham and herself and their four dimin tive children... Kham and $\mathrm{Be}$ had six children by 196!. They travellec almost constantly, and"People in the bands they visited gave them me Independent:

others gave the family meat.

semi-independent; Be gathered roots and vegetation, bu

Infanticide--general ( 166 )

Infanticide/senilcide (disabled only): not disabled only.

Comments: !Kham adapted to his disability and he and Be "made ther selves useful by carrying messages and gifts from one person to another and brought the news and gossip to the countryside"(187) in exchange for meat from the poople they visited. Marshall associates their "hold on a group and a place to belong," as the most "tenuous" of any other Bushmen she knew. This was partly because they were "landless and unattached" and partly because of his disability. Other: !Kham's marriage, despite his inability to hunt, indicates that the band did not prevent him from marrying. 
Author: Marshall; Lorna

Reference:

The !irung of Nyae Nyae

HRAF Code: FXIO Card:

Disability

Data on Individual
Africa

Bushmen

11: 19

FX10

Name of Culture Unit: !Kung of Nyae Nyae

Location of Group, Society, Culture: Nyae Nyae area, NW corner, Kalahari Desert,

Time Frame: 1950's to 1960's

Individual: Name or description: Lame $\neq$ Gao

Type of Disability: one leg withered from bone disease. (186-187) "he limped with a cane."

Age Disability Acquired: Probably around 17 years of age. $(194,9 n)$ Status and riole: He achjeved manhood"by killing (a byck and was Position in Family: Husband.

Dependent: After he becarne crippled LamekGao's mother N/aoka carried him on her back for years. (288)

Independent: Hunter. This had occurred by 1959.

Infanticide/senilcide (disabled only):

Comments: This account ties in with that of Elizabeth Marshall Thomas's, The Harmless People (197.).

Other: 
Author: Marshall; Lorna

Reference:

The !Kung of Nyae Nyae

\section{HRAF Code: FXIO Card: Category:}

Name of Culture Unit: !Kung of Nyae Nyae

Location of Group, Society, Culture: Nyae Nyae area, NW corner, Kalahari Desert,

Time Frame: 1950's to 1960's

Individual: Name or description: Lame $\neq$ Gao

Type of Disability: one leg withered from bone disease. (186-187) "he limped with a cane."

Age Disability Acquired: Probably around 17 years of age. $(194,9 n)$

Status and Krole: He achieved manhood"by killing a buck and was Position in Family: Husband.

Dependent: After he becane crippled LamefGao's mother N/aoka carried him on her back for years. (288)

Independent: Hunter. This had occurred by 1959.

Infanticide/senilcide (disabled only):

Comments: This account ties in with that of Elizabeth Marshall Thomas's, The Harmless People (197.).

Other: 
Author: Marshall; Lorna

Reference: The !Kung of Data on Individual of Nyae Nyae

HRAF Code: FXIO Card:

Category:

Name of Culture Unit: !Kung of Nyae Nyae

Location of Group, Society, Culture: Nyae Nyae area, Kalahari Deser Africa

Time Frame: Contemporary, c. 1950 's-1960's.

Individual: Name or description: Short/Qui

Type of Disability: Lost leg after being bitten by a puff adder; wears a wooden leg. The band saved his life by sucking out the pois but gangrene set in and he lost his foot. The Marshall's took him to Windhoek where he was operated on and given a wooden leg. (142)

Age Disability Acquired: Adult, considered best hunter in Nyae Nyae area. (142) After accident, continued to hunt.

Status and Role: Respected member of community; best hunter.

Position in Family: Short/Qui's family took care of his needs whe he was bitten by the snake and after he was well he evidently resumec his position.

Dependent:

Independent: Hunted after accident, but/last contact with him, Short/Qui "evaded giving a direct answer to question about his huntin by making a joke. His wife now did the running he said." $(142,7 \mathrm{n})$

Infanticide/senilcide (disabled only):

Comments:

Other: 
luthor: Thomas, Elizabeth $\mathrm{M}$.

IReference:

The Harmless People

\section{HRAF Code: FXIO Card: Category:}

Name of Culture Unit: Nama Warf Bushmen

Location of Group, Society, Culture: Nama Pan, Kalahari Besert, N.W. Corner, Africa

Time Frame: c. 1958-1959

Individual: Name or description: Short Kwi, the same person that Lorna Marshall refers to as Short/Qui.

Type of Disability: Short Kwi lost lower part of leg as a result of being bitten by a puff adder. His foot became gangrenous, fell of The band buried his foot "as if it was a person."(238)

Age Disability Acquired: Adulthood, best hunter in band.

Status and Role: His status probably changed when he became cripple Thomas says: "It depresses Bushmen terribly to see one of their mem-

Position in Fumily: bers crippled, which of course, in almost every case means the end of that person's productive life as a support of the people.

Dependent: Short Kwi was dependent during the time his foot was gangrenous and fell off.

Independent: Short Kwi became independent after being fitted with a peg leg that he could repair; he resumed hunting and was still considered the best hunter for a time. (See Marshall, Lorna: 142,7n)

\section{Infanticide/senilcide (disabled only):}

Comments: Thomas points out that a disabled person becomes "a poor person and depends upon the enforced charity of one's near relatives while suffering avoidance by one's remoter kin." (246)

Also, Thomas that even with his peg leg Short Kwi "was still a crippl and always would be. They did not relate his type of disability with that of the "lame boy" who had hunted successfully. (250)

Other: The Band had hoped for a miracle to occur to heal short Kwi's gangrene. Their attitude linked to supernatural events. 
Author: Thomas, Elizabeth M.

Reference: The Harmless Data on Individual

People

HRAF Code: FXIO Card: Category:

Name of Culture Unit: Bushmen, Gautscha Pan

Location of Group, Society, Culture: Gautscha Pan, N. W./Kalari Desc

Time Frame: c. 1958-1959

Individual: Name or description: Tu's brother, lame boy.

T'ype of Disability: "crippled in one leg since childhood."(197)

Age Disability Acquired: childhood/"He could hobble only with aid of one stick."(197)

Status and Fole: Member of band and family, but "despaired of ever becoming a hunter or inheriting headmanship. "(197)

Position in Pamily: son.

Dependent: while growing up.

Independent: After he shot Kudo, he had been scarified and ininitiated into adulthood.

Infanticide/senilcide (disabled only):

Comments:

Other: 
Author 2: Masters,

Reference :

Disability

Data on Individual
Miunte was

Kurds $:$ MAIl

HRAF Code: MA 11 Card: 034

Category: 732

Name of Culture Unit: Kurds in Rowanduz

Location of Group, Society, Culture: Rowanduz

Time Frame: c. 1950's

Individual: Name or description: Hajji Mustafa who is considered slightly demented.

Type of Disability: slightly demented/mentally ill

Age Disability Acquired: Not known.

Status and Role: / The worst barber in the bazaar."(329)

of Hajji liustafa, who ahds colour and noise to town people are fond

Position in Fumily: dearly loved by the children.

Position in ramily: Husband and father

Dependent: Yes. ". . he and his family are tacitly supported by the house of Shakir Effendi with 'gifts' of food and money. "(329)

Independent: To the extent that he lives outside an institution and moves about the town freely; lives with his family; and evident has some say about how family resources are used.

Infanticide/senilcide (disabled only): Evidently not; (255) Islamip."precepts prohibit any type of birth control, abortion. . .

Comments:

Other: "I cheerful egotist, he (Hajji Mustafa, . . .discovered soi thing in the Darwish movement which offered him the social status he desired, having been dissatisfied with otber fields of endeavor."(329 
Author: $2:$ Stefansson

lieference :
Disability

Data on Individual
North America Copper Eșkimo ND\&

HRAF Code: ND8 Card: 072 Category: 736

Name of Culture Unit: Copper Eskimo

Location of Group, Society, Culture: Coronation Gulf area of the Canadian Northwest

Time Frame: (1908-1912) 1914

Individual: Name or description: l) "Avranna," about forty-five totally blind, Clouston Bay

2) "at Prince Albert village--old man--about 60)

Type of Disability: blind

Age Disability Acquired: as an adult (both)

Status and Role; Husband

Position in Family: Husband

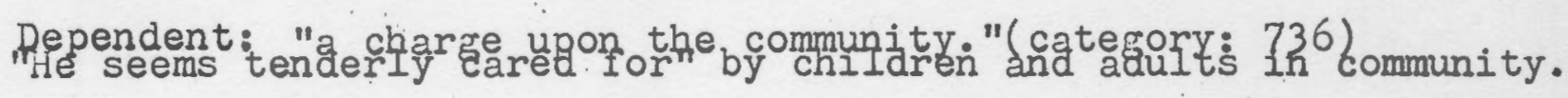

\section{Independent:}

1) Explanation for blindness: Avranna was seal fishing; other men were distance. He killed a large seal (bearded) without anyone seeing him the group were supposed to share large seals but not small ones; "he pledged his wife to secrecy"when he cut it up. But others found out and were angry with him and took away the skin and meat. He was

Other: "crushed" by the "disapproval" of the people; in a year he began to go blind. (736)

He attributed his blindness to his selfishness.

2) The blindness of the other old man was attributed to selfishness too because "he grudged to let them help themselves" when he kill a large ugrug. (category: 736) 
Author: Shuman, Malcolm K.

Reference: "Culture and

Deafness in a Maya Indian

Disability

Data on Individual
North america Nucatdn : * :

Village," in: Psychiatry, Vol. 43, Nov. 1980.

\section{HRAF Code: NV10 Card: Category:}

Name of Culture Unit: Mayan Indians

Location of Group, Society, Culture: Nohya Village, Central Yucatan peninsula, Yucatan, Mexico

Time Frame: 1970's

Individual: Name or description: Lorenzo, is the oldest and first deat person in village. "Alert and intelligent" (361) "Lorenzo,.. a talented artist and cuts out tissue papaer decorations for the oc(360-362) casional dances; indefatigable worker, a leader, not officeholder." Type of Disability: deaf.

Age Disability Acquired: at birth; Lorenzo's deafness, probably genetic in nature. $(360-361)$.

Status and Role; Highly respected. Village proud of Lorenzo's accomplishments. (361)

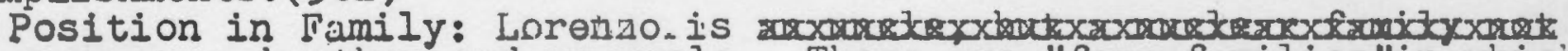

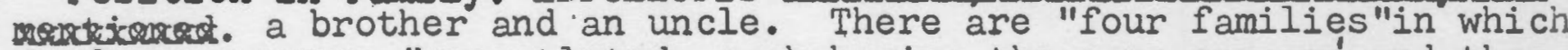
deafness occurs, "are related, each having the same surname and the

Deprendenter oldest deaf person; Lorenzo, is the brother of the head of two of those families, and nephew of the other two heads."

Dependent: No.

Independent: Lorenzo is not only a hard worker, but he is meticulou about detail and insists on performing takks properly; he tends to do ineer to tell others how to do things. In addition to his artistic ability,-ho-is a "talented weaver," and "makes baskets as well as ham mocks:" He also works in the fields and on communal work details.

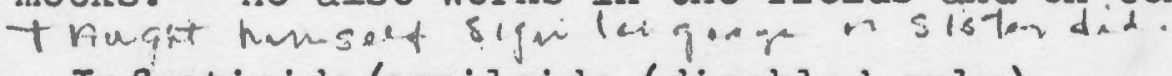

Infanticide/senilcide (disabled only):

Comments: Lorenzo is not included in two thajor social activities; he has not married (although he has tried), and he has never been ask to be a godfather; thidrias important because the "institution of co"It is significant that Lorenzo has never been asked to serve in this capacity "( 364 ) it helps the godfather to "forge "a link with

Other: Explanation for deafness: Regarding the failure of the deaf to marry, the author pointed out that, "People in Nohya do not know what causes deafness and tend to attribute it to destiny, but one sus pects that they have a latent realization that it may be hereditary." (3 61) 
Author: 2: Barton

Reference:

Disability

Oceania

Ifugao

Data on Individual

OA19 (1) $\therefore$

HRAF Code: OA19 Card: 067 Category: 164, 627, 732

Name of Culture Unit: Ifugao

Location of Group, Society, Culture:

Time Frame: (1908-1914) 1919

Individual: Name or description: Piklud, a fairly wealthy man of Kurug

Type of Disability: "paralyzed from the rees down and in his locomotion he had to crawl on all fours." (69)

Age Disability Acquired: not known

Status and Role; wealthy man

Position in Family:

Dependent:

Independent: Probably, since he was wealthy

Infanticide/senilcide (disabled only):

quotes from Laws:

Comments: "ihe author quamest: "Cripples adn those afflicted by disfigurements or disfiguring diseases are often in a desperate mood for the reason that life is not all precious to them. They are likel to be erratic and to constitute exceptions in punishment of crimes an procedure."(69) Author citels example: Piklud loaned a neighbor a chicken and they quarrelled over repayment of it; bad feeling between the two men. "X little while after the quarrel, the neighbor met

Other: Piklud crawling along the path through the village, and called to him as to a dos. . Piklud pretended not to notice and even feigned amiability. He gossiped a little about the drought which was parching the rice fields. Finally he said, "Let me see your spear." Be felt the edge with the words, 'It is pretty sharp, isn't it?' he thrust it upward into the other's abciomen." (69) Author does not note Piklud's punishment, if any. 
Author: Dubois, Cora

Reference: The People of Data on Individual

Alor, Psychological Study of an East Indian Island

HRAF Code: OF5 Card: Category:

Name of Culture Unit: Mountain people at Atimelang in the Barawahir district.

Location of Group, Society, Culture: "community lies above the nort west coast in the radjahship of Alor proper." (17)

Time Frame: c. $1950^{\prime} \mathrm{s}$

Individual: Name or description: "Rilpada: of five iblings. He is a seer. . He is a dreamer and an inter preter of dreams. " $(285)$ "He is as much of a mystic as one can expe to find in this society." $(284)$

Type of Disability: "... he is blind in one eye, is crippled and emaciated, and has an irritating skin disease."(285)

Age Disability Acquired: Probably as a young adult. (24l-242) (about twenty-six) (243)

wealth." 2 ans

Position in Family: He is one of five children; his father is dea but was a "prominent seer. . The son not only follows his afather's $v$ cation as a seer, but he is constantly occupied with" father's financ

Dependent: Rilpada is married to a woman who is ten years older th he and who has two daughters from a previous marriege. (285)

Independent: He is probably independent receiving food and other necessities from offerings of villagers.

Infanticide/senilcide (disabled only):

Comments:

Other: 
wuvar: kuschel, Rolf

Disability Oceanie

Reference :

"The Silent. Inventor: The

Dato on Individual OT9

OT9 $(1) \ldots 0^{\circ}$

Creation of a Sign Language by the only pear-Mute on

e. Polynesian Island." in: Sign Language Studies

HRAF Code: OT9 Card: Category:

Name of Culture Unit: Rennell Island

Location of Group, Society, Culture: Bennell Island, part of Britis Soloman Islands

Time Frame: 1915 \pm years; and March and July 1972 when Kuschel vis: Rennell Island.

Individual: Name or description: Kangobai the only deaf mute on renreII fland in twenty-four generations of oral history. He was bo in 1915 E five years. "His handicap notwithstanding Kangobai is phys. ically apdisinsofar thave been able to determine mentahly) well deve opype of Disability:

Dear and mute.

Age Disability Acquired: Born with disability

Status and Rolej Respected as hardworking and "skilled at whatever he undertakes." (6)

Position in Family: Son from a high-status family on the island.

Dependent:

Independent: "He' often plants large gardens and frequently gives away food according to the Polynesian custom. He is also a skilled fisherman. These two skills are prized in Polynesian culture and brin Kangobai social status.(6)

Kangobai stayed and worked on the Russells Islands for eight months on a sugar plantation. (7)

Infanticide/senilcide (disabled only):

Comments: Kangobai invented the sign language he uses which shows "creativity and imagination." He gețs along with the hearing members of population as well as possible. However, he is not married, and the extent of his problem is not fully understood by everyone.

Other: 
Author: Bogoras

Reference:
Disability

Data on Individual
Russia

Siberia

Chukchee RY2

HRAF Code: RY2 Card: Category: 158

Name of Culture Unit: Chuckchee and Reindeer Division of Tribe Location of group, society, culture:

"'ime Erame: (1890-1901) 1904-09

Individual:

Name or Description: 1) woman shaman, "out of her mind for three years.

2) Man of Reindeer tribe afflicted with fits.

Type of Disability: madness and fits

Age Disability Required: ?

Status and Role:l)Shaman 2) man (?)

Position in family: --

Dependent:

Independent:

Means of Subsistence:

Other: I) Woman "frequently would want to harm other people, and ther her housemates would tie her hands and bind her to one of the housepol 2) Man "...for a long time afflicted with similar fits, (and) kept ma ing attempts to injuee his camp companions, and ultimately was put out of the way by common consent." 
Author: De Smidt

Rieference:
Disability

Data on Individual
South America

Cuna

SB5

HRAF Code: SB5 Card: Category: 826, 116, 143, 582, 81 Name of Culture Unit: Cuna Indians

Location of group, society, culture: San Blas Islands and mountain interior. Time Frame: (1947?) 1948

Individual: Name or Description: "two albino brothers about. 50 years of age."
Both highly respected.

Type of Disability: Albinoes

Age Disability Required: at birth

S.taths and Role: 7 lo chanter. Of Hot position in lamily: unmarried regular medicine man and chanter." not marry them)

Dependent:

Independent: As councilmen, medicine men, and other official positions, they must be independent, but no feferences found as to their specific means of subsistence.

Means of Subsistence:

Other: 
Author: Henry

lieference:
Disability

Data on Individual
South America

Cuna-Aweikoma $\mathrm{SM} 3$

HRAF Code: SM3 Card: Category:

Name of Culture Unit: Caingang--Aweikoma

Location of Group, Society, Culture: State of Santa Catarina, Brazi

Time Frame: $(1932-34) 1941$

Individual: Name or description: "Kemblin was one of those rare Individuals about whom supernatural influences seemed to cluster."

Type of Disability: Kemblin had only one arm.

Age Disability Acquired: As an adult when he"refused power from snake, who therefore bit him in anger."

Status and Role: As Kemblin "grew older he gradually accumulated the powers of Quati, Monkey, Wind, and Fish..."

Position in Family: unknown

Dependent:

Independent: Probably independent but not known; he had power.

Infanticide/senilcide (disabled only): --

Comments: His death was attributed to the day Quati "was out of sorts with Kemblin for some unknown reason, and he fell sick and died." (77)

Other: 
Author: Bogoras

Disability

HRAF Code: RY2 Card: 108 Category: 732

Name of Culture Unit:

Location of group, society, culture:

;ime Frame:

Individual: a man with sexual abnormality

Name or Description: an old man

Type of Disability: sexual abnormality

Age Disability Required: infancy from mother not cleaning infant's bottom frequently and thoooughly.

Status and Role:

Position in Family: no family; not allowed to marry

Dependent:

Independent: "lived as herdsman in a camp of a rich reindeerbreeder. He slept in the house of his master...

Means of Subsistence: herdsman

Other: "Sometimes when feeling dull, he woüld take a drum and begin to drum and sing, 'Oh, oh, oh! From the hands of my mother I got a swelling on my penis." "

Note: Bogoras did not meet this man, but had heard about him. 
Author: Wrangell

Reference:
Disability

Data on Individual

HRAF CODE: EY2; Card: Name of Group: Chukchee Location of Group: Russia

Time Frame: (1826- - )1844

Individual:

Name or Description: "Waletka's father"; "one of richest and most respected chiefs."

Type of Disability: aged infirm

Age Disability Acquired: old age

Status and Role:

Position in Family: Respected chief and father

Dependent:

Independent:

Means of Subsistence: rich

Other: "Waletka's father became infirm and tired of life, and wa. put to death at his own express desire, by some of his "nearest relatives." 
:

HRAF Code: RI2 Card: 108 Category: 732:

Name of Culture Unit: Chukchee/Reindeer

Location of group, society, culture: Russia

Time Frame: (1878)1882

Individual:

Name or Description: "Keuto(JMR: a deaf half-idiot) *

Type of Disability: a deaf half-idiot

Age Disability Required: born with

Status and Role: worked for anthropologists

Position in liamily: --

Dependent:

Independent: at least to some extent--Nordenskiold repórted that Keuto was "an obliging youth who did all he could to be of use to them "and was a skillful archer."

Means of Subsistence: probably hunting and being useful to other:

Other: *Many deaf persons considred to be idiots; may have been perceived in the same way in Russia. 


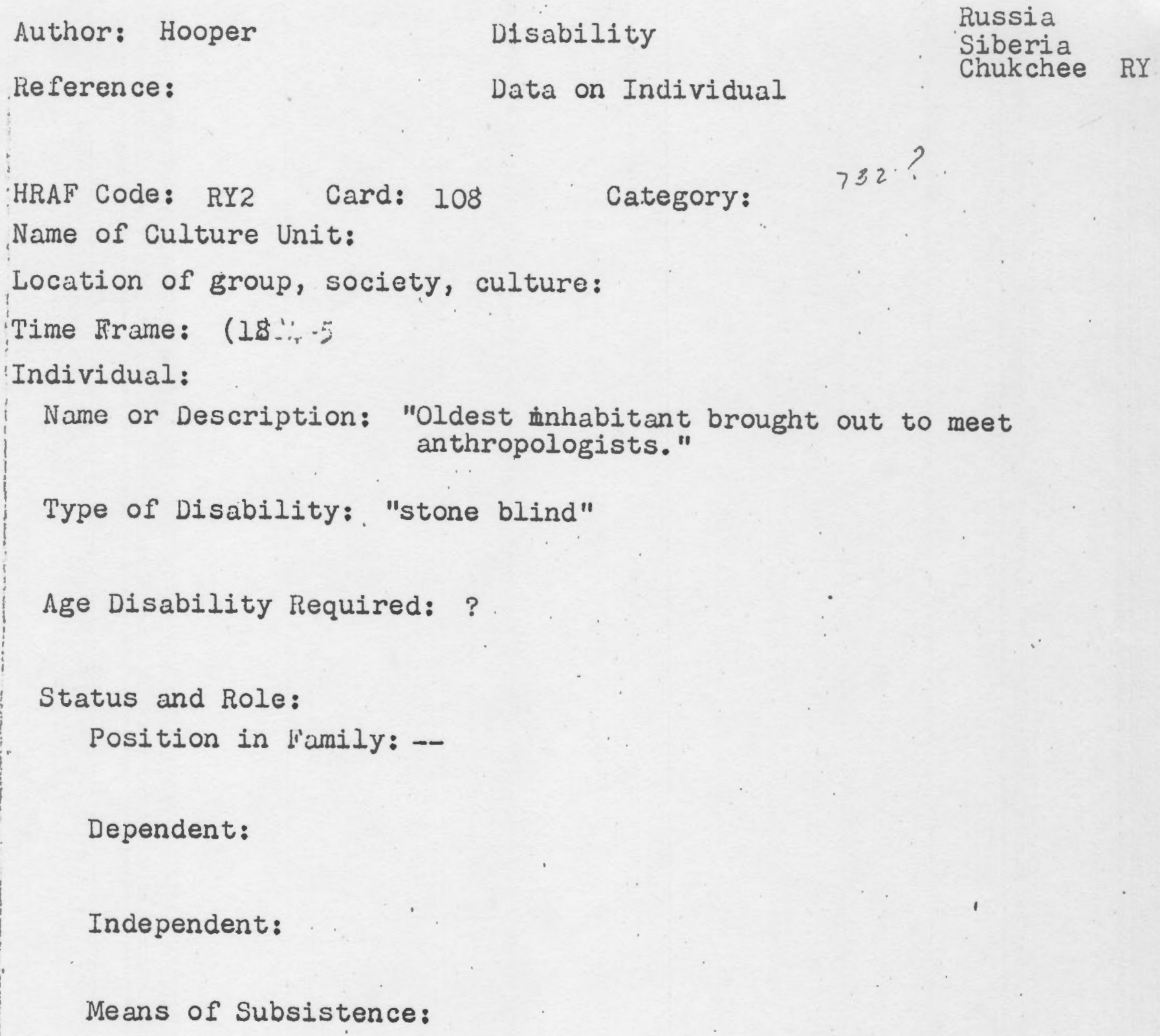

HRAF Code: RY2 Card: 108 Category:

Name of Culture Unit:

Location of group, society, culture:

Time Frame: (18:,-5

Individual: anthropologists."

Type of Disability: "stone blind"

Age Disability Required: ?

Status and Role:

Position in framily: --

Dependent:

Independent:

Means of Subsistence:

Other: 


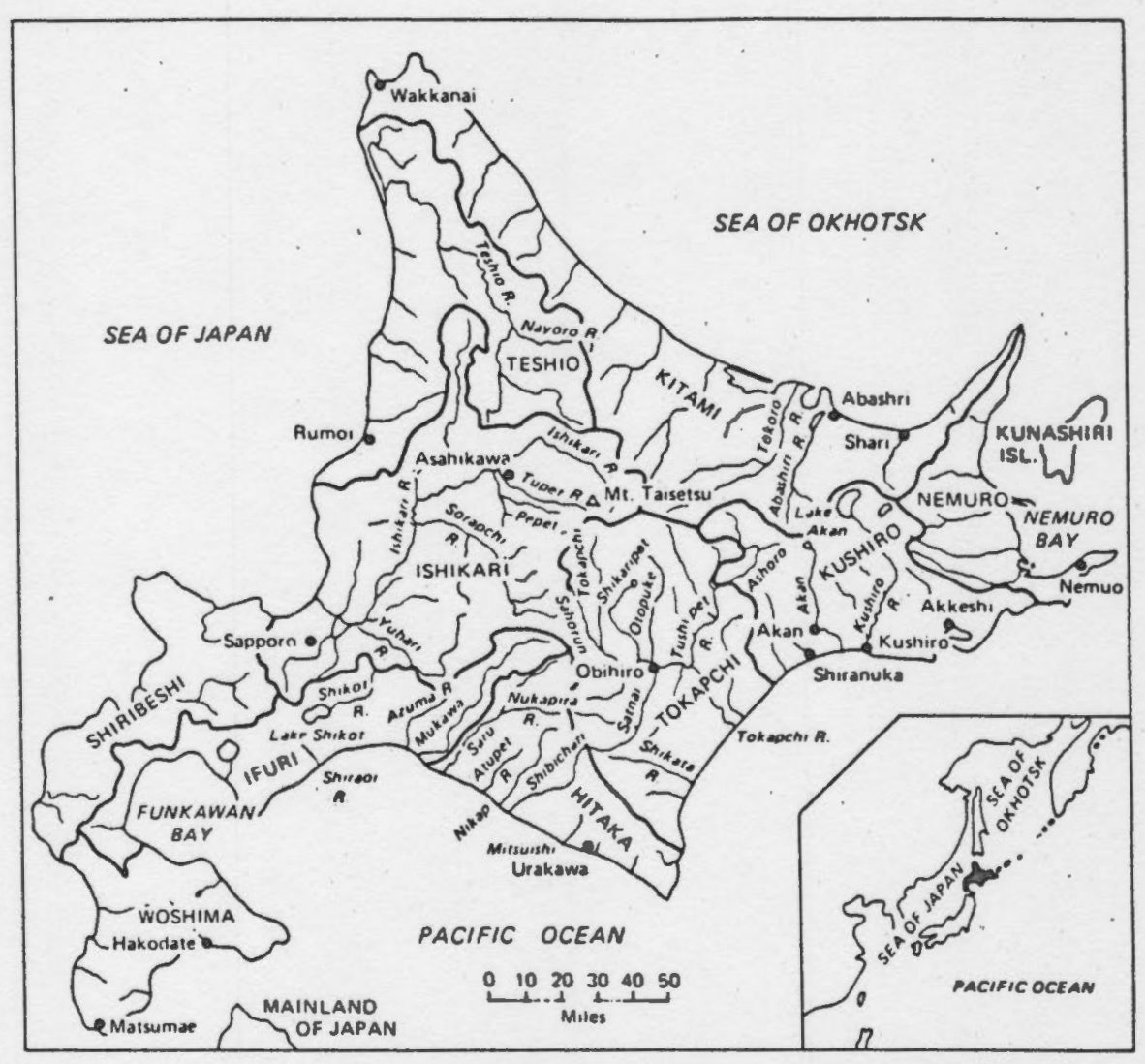

Figure 11-1. Rivers of Hokkaido and old administrative divisions. 

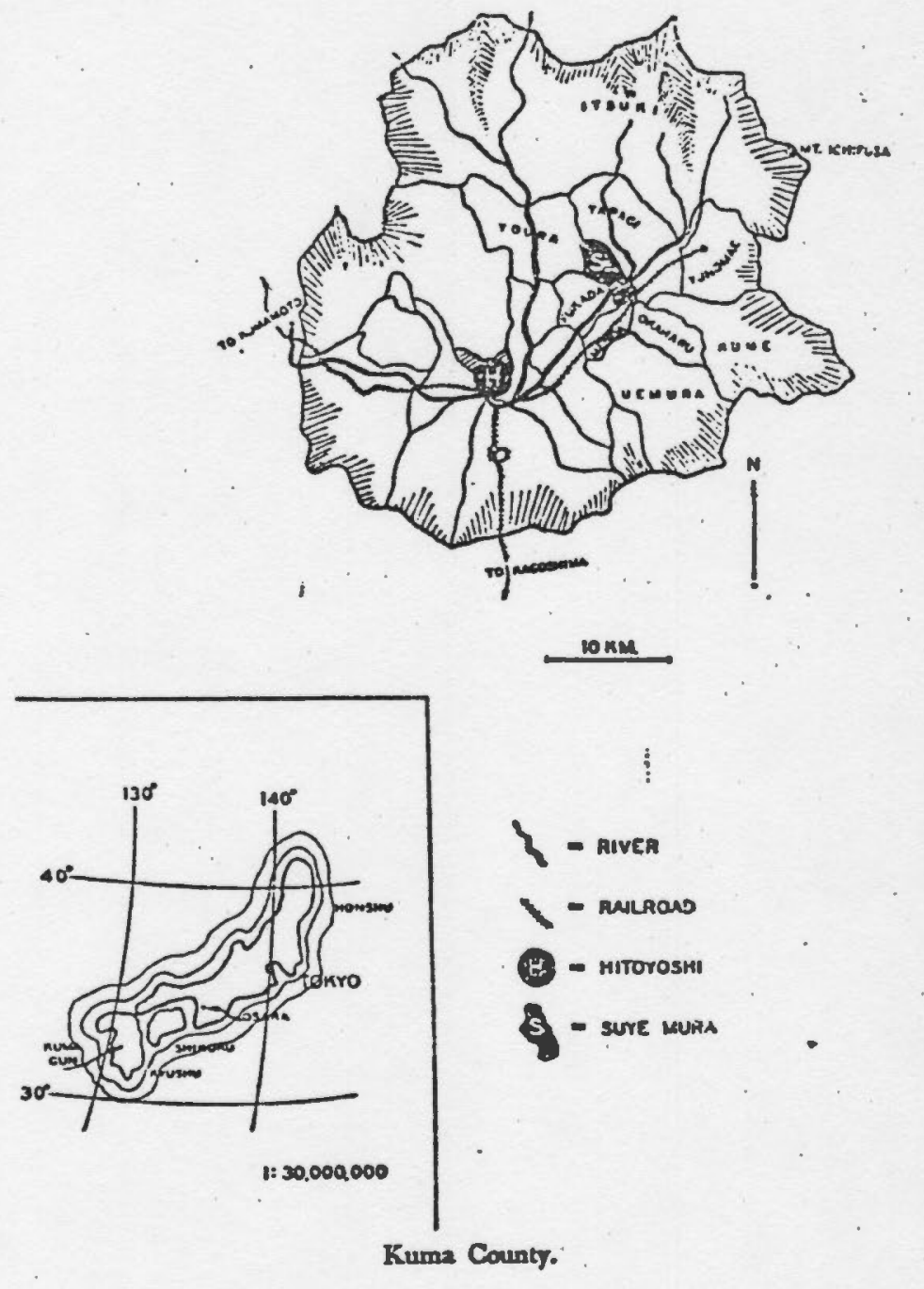


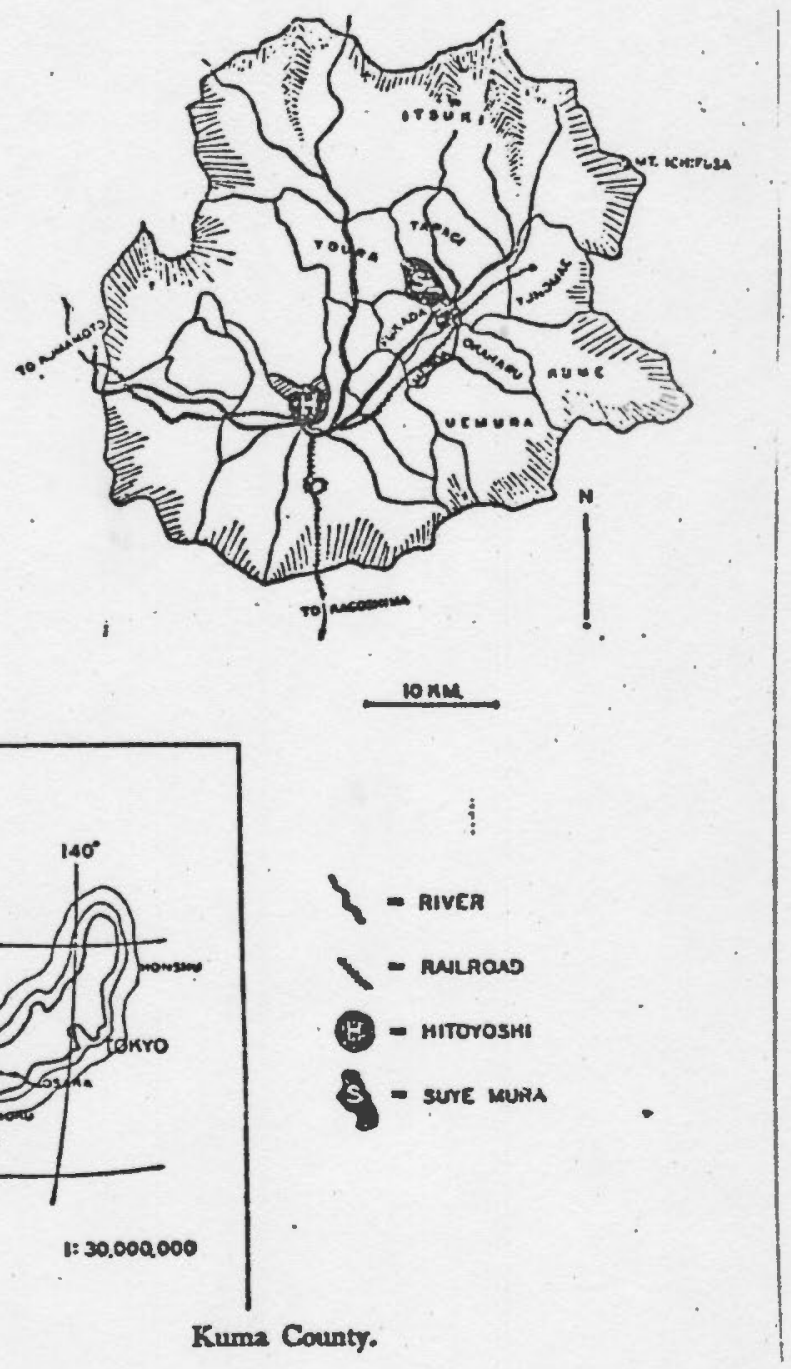




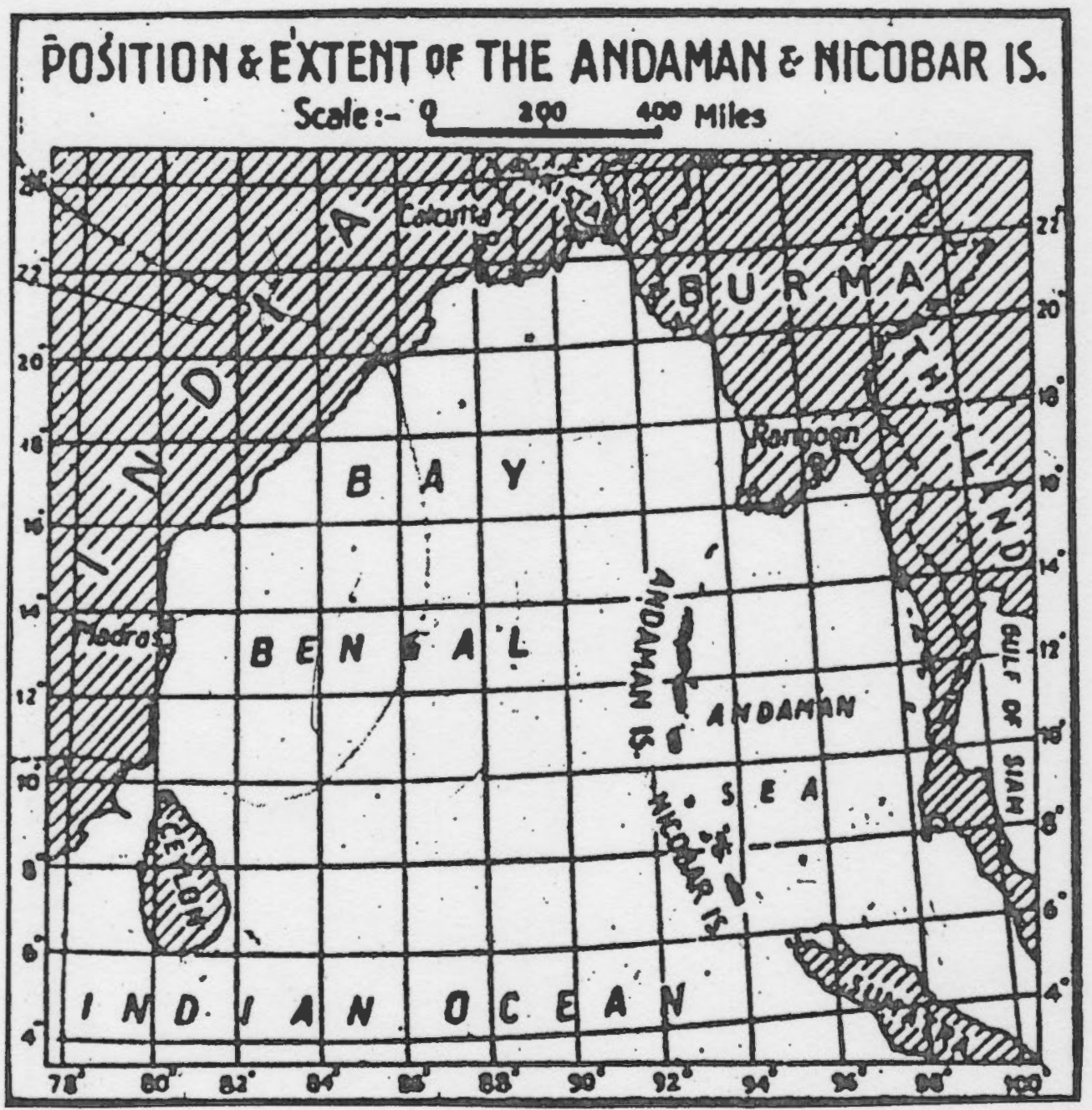




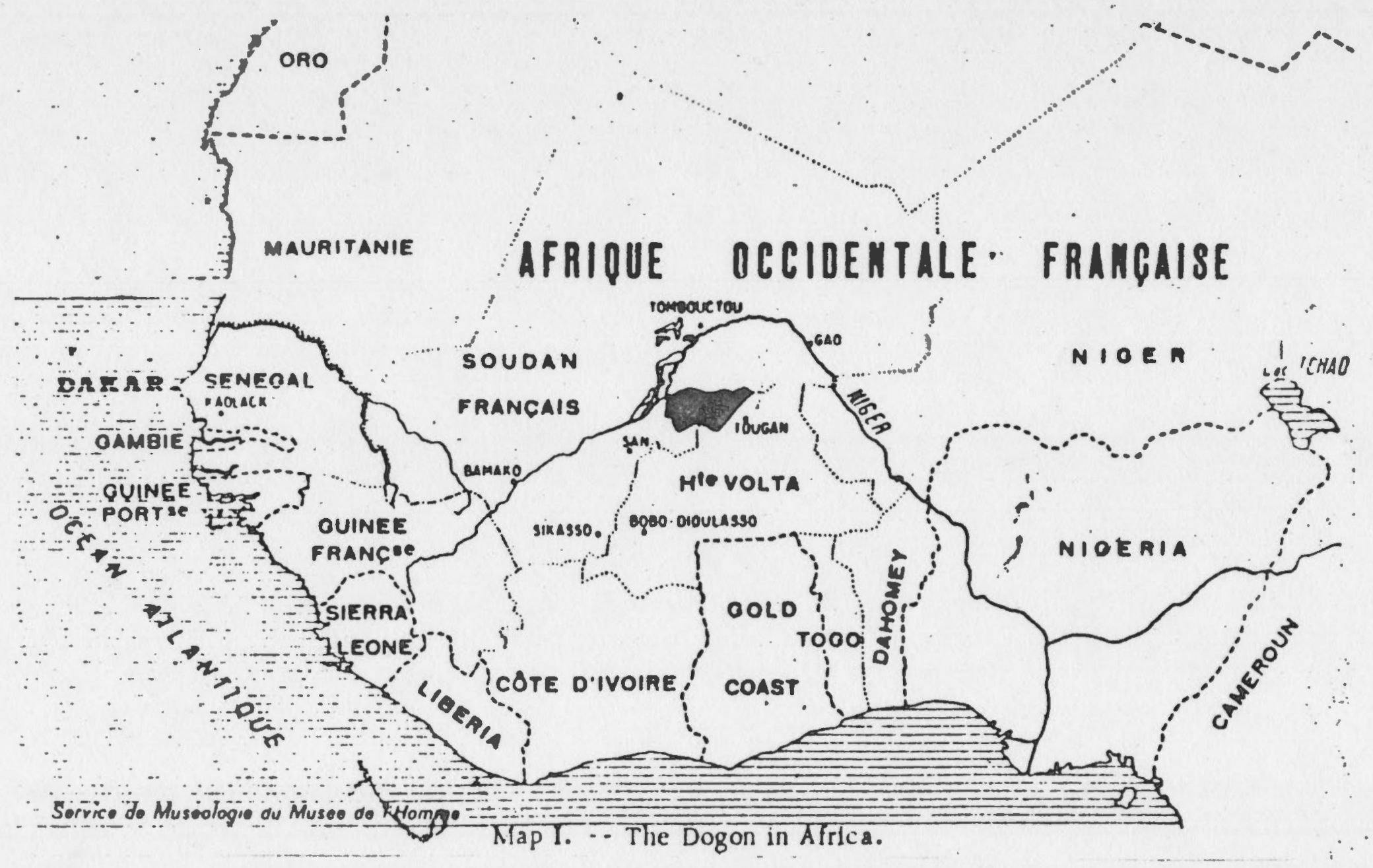


FJ12

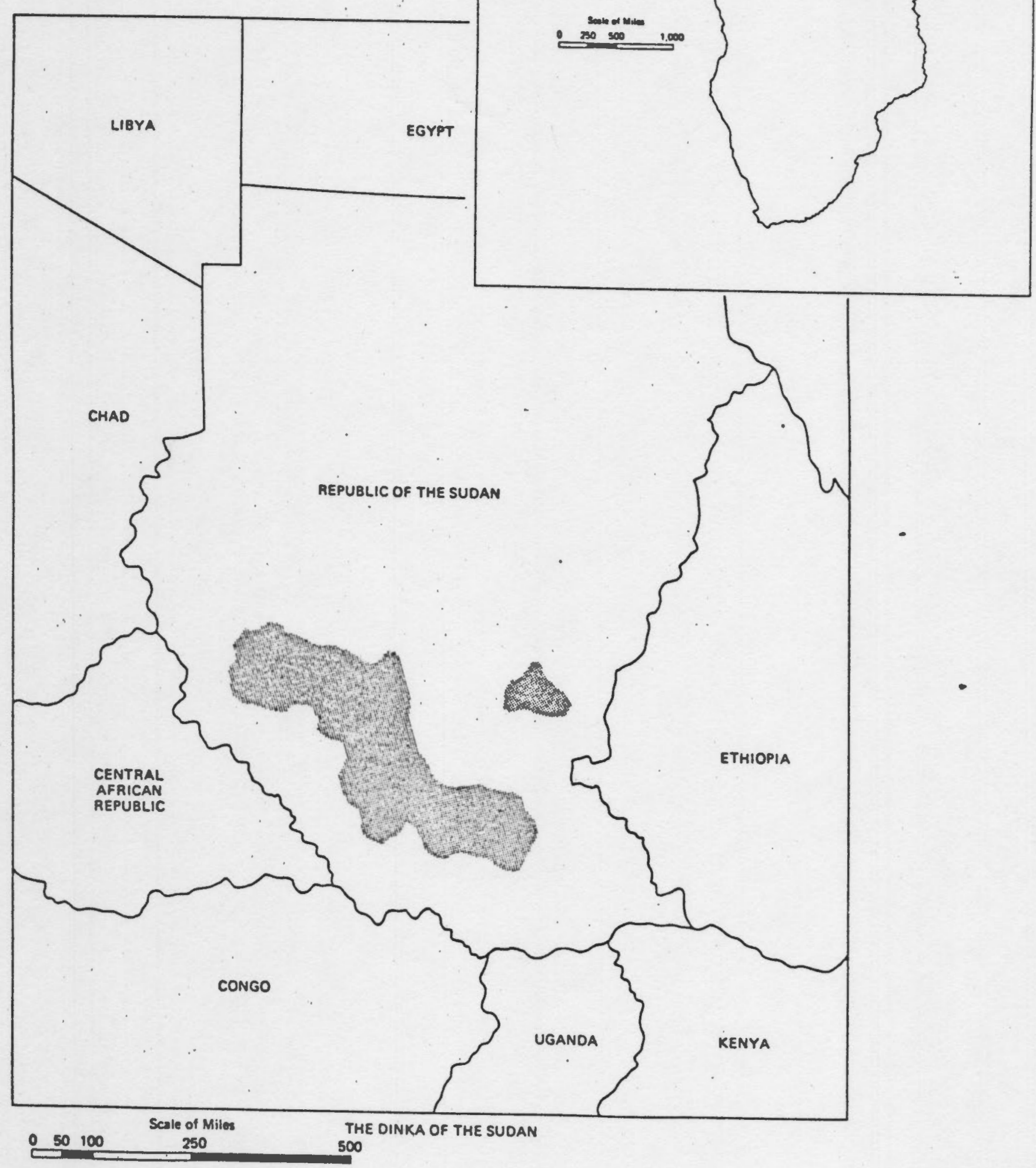


Barukat. Koka

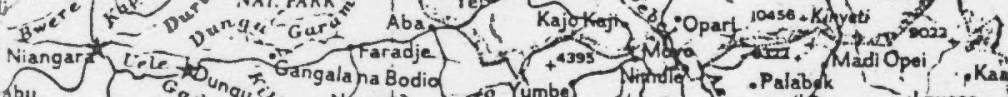
bu mokerarge Rungu

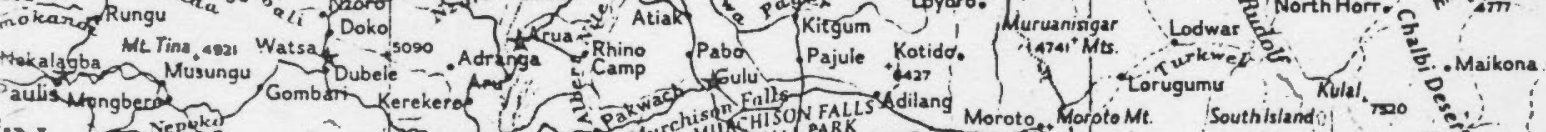

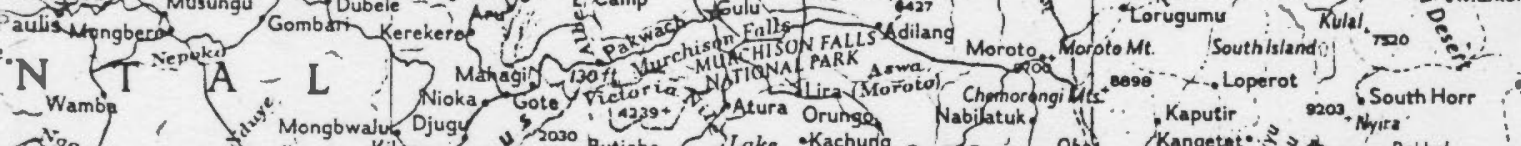

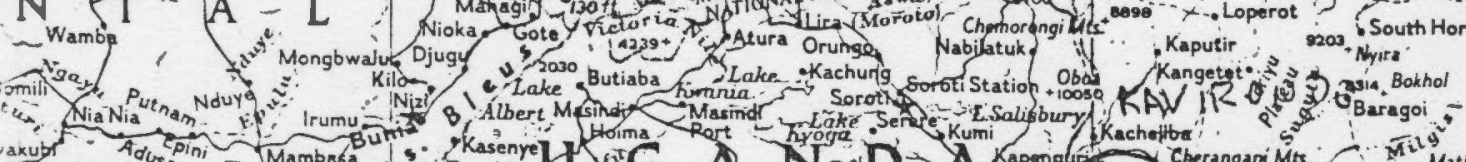

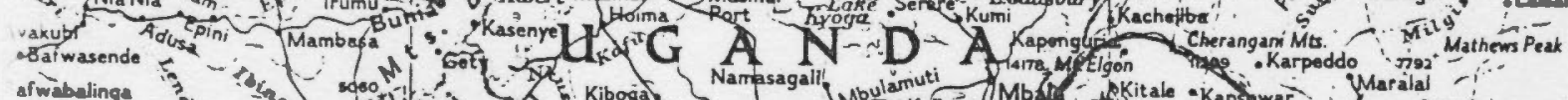

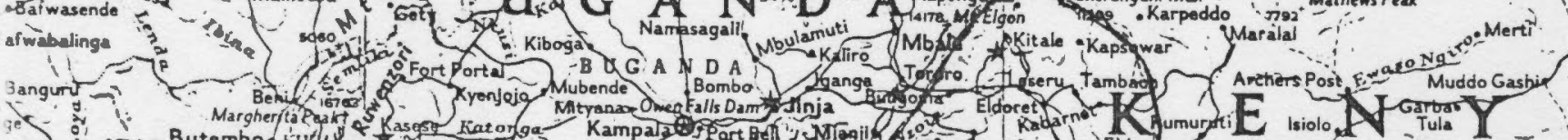

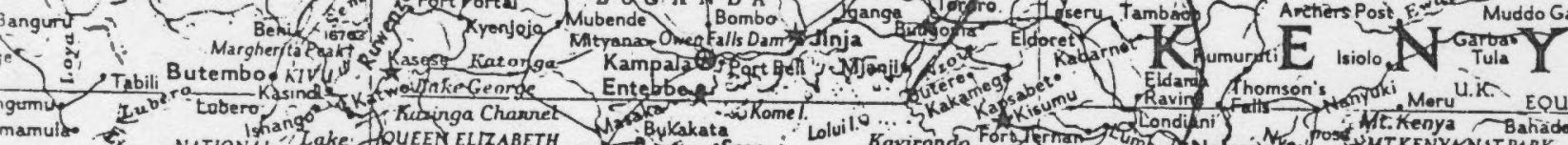

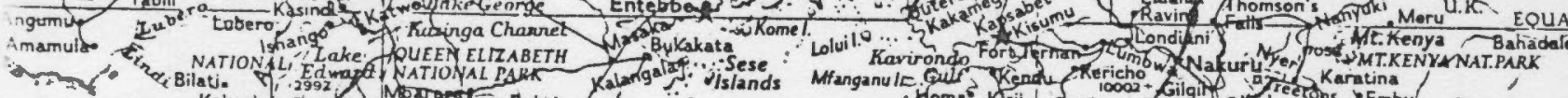

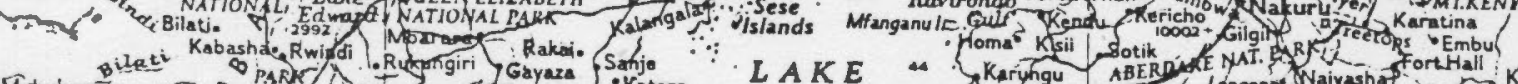

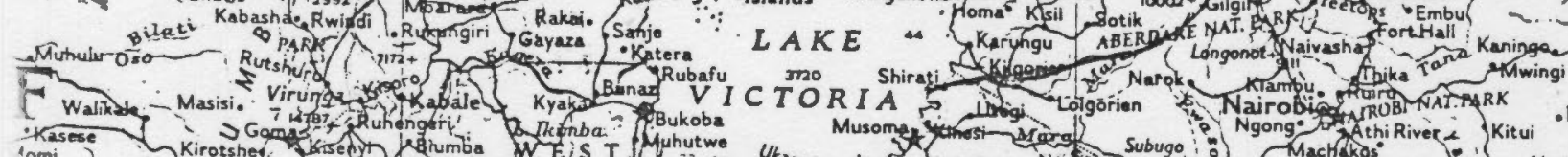

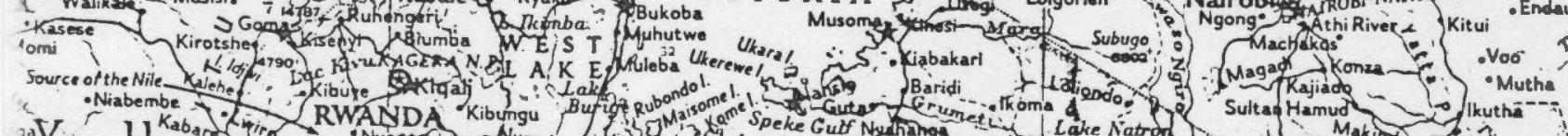

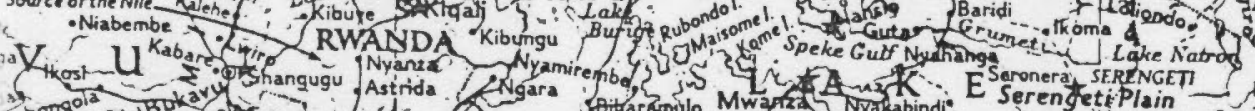

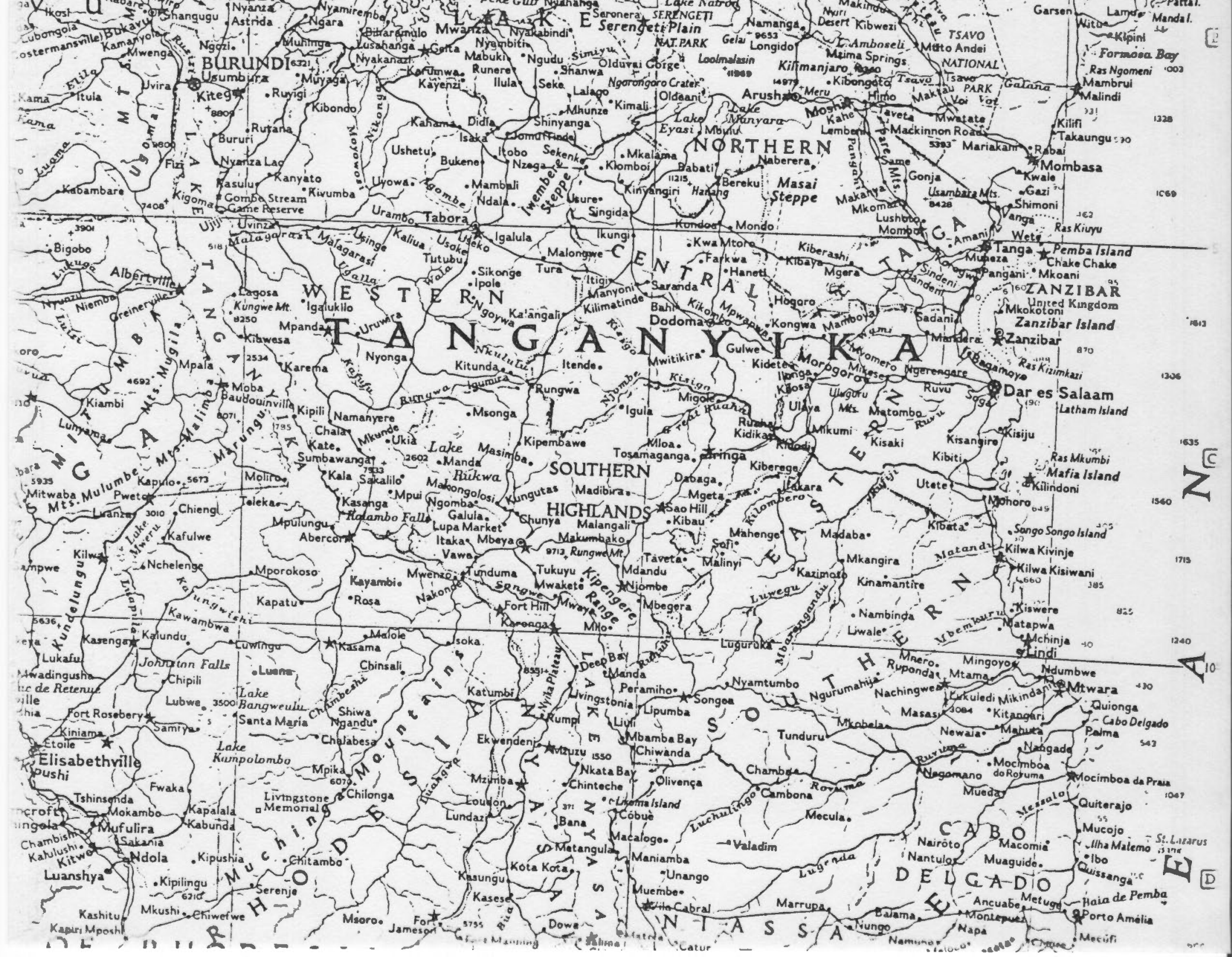




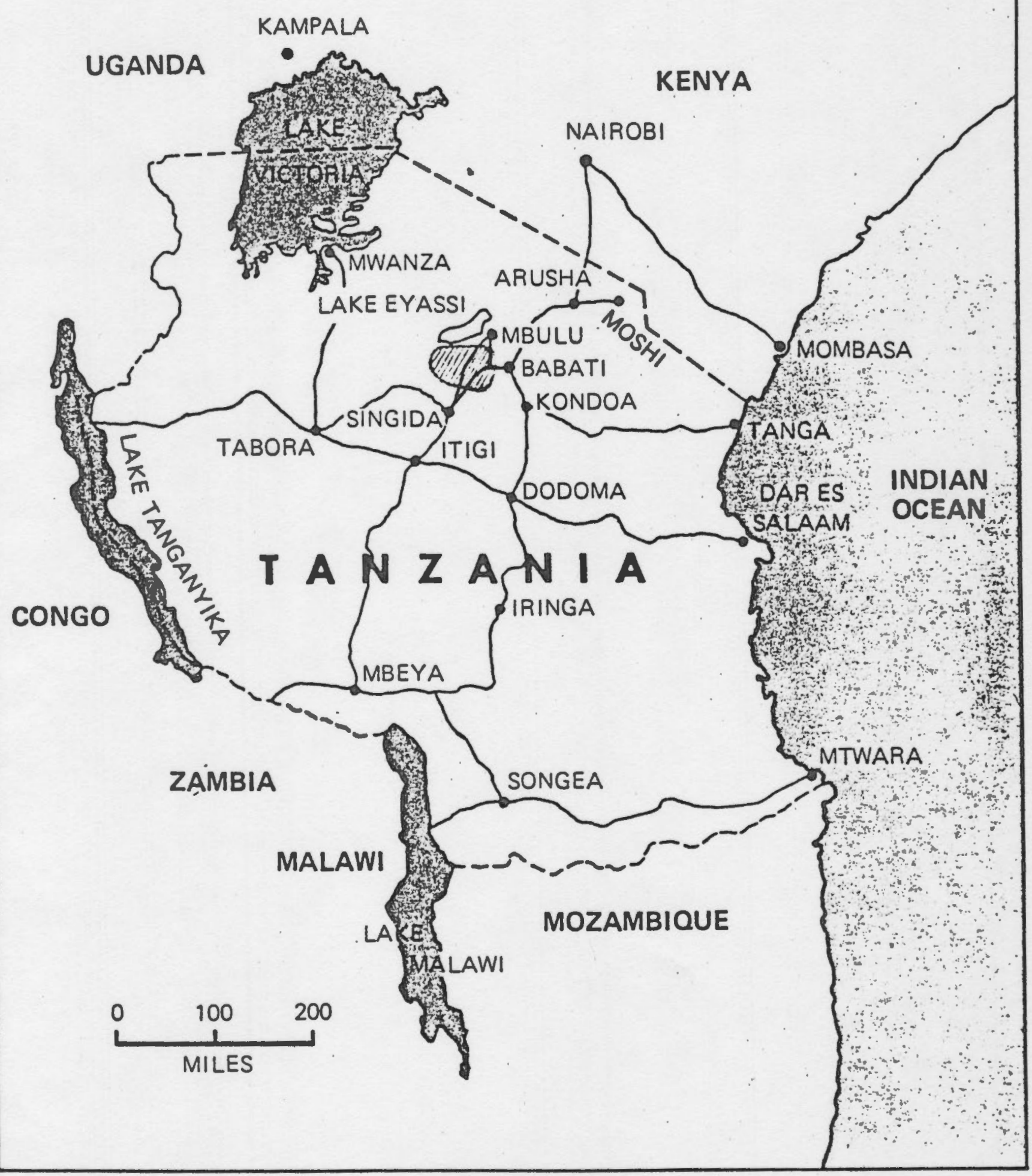

- - Political boundary

Map of Tanzania

Roads (Main connecting)

- Towns and cities 11110 Barabaig territory 


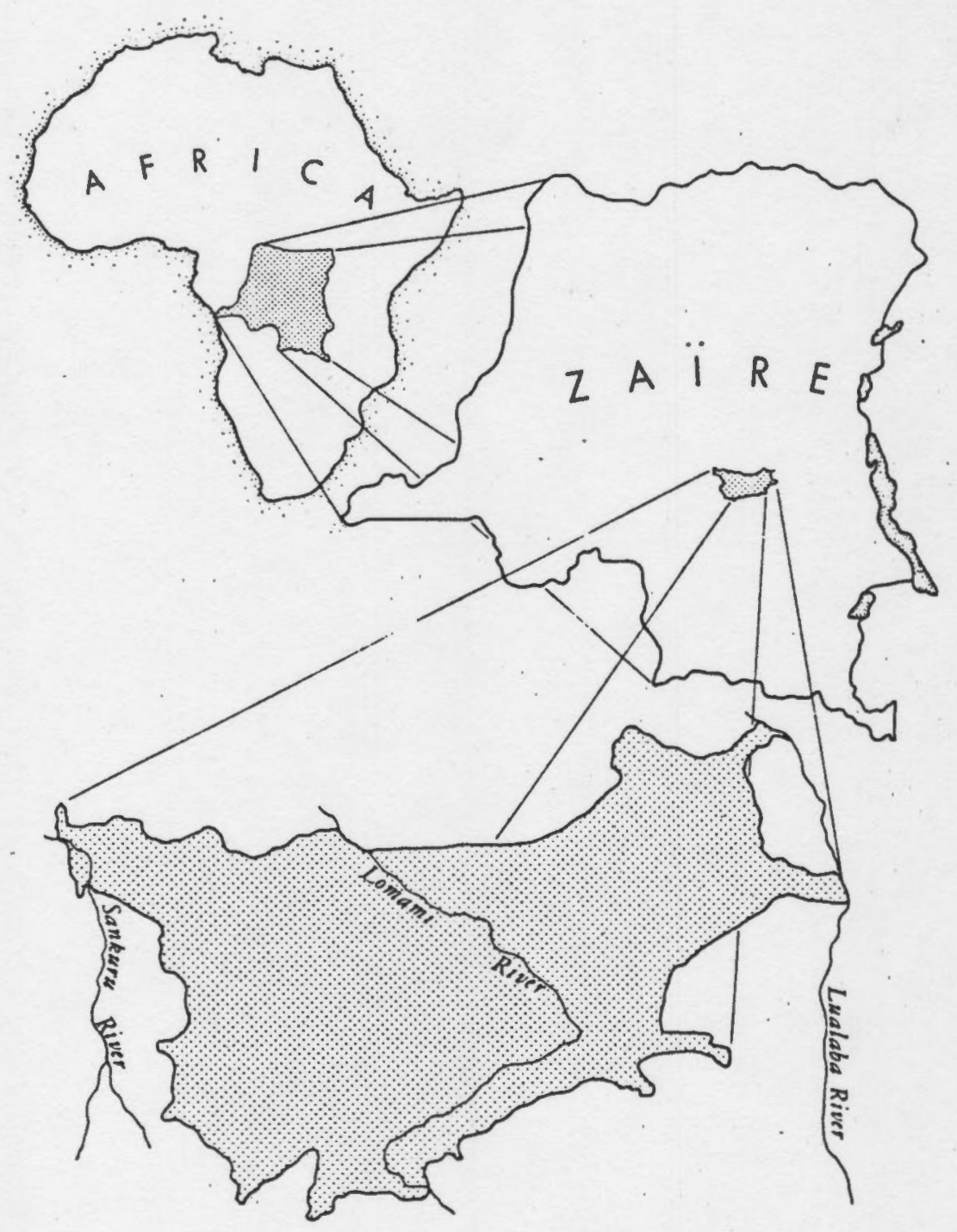

Location of the Basongye
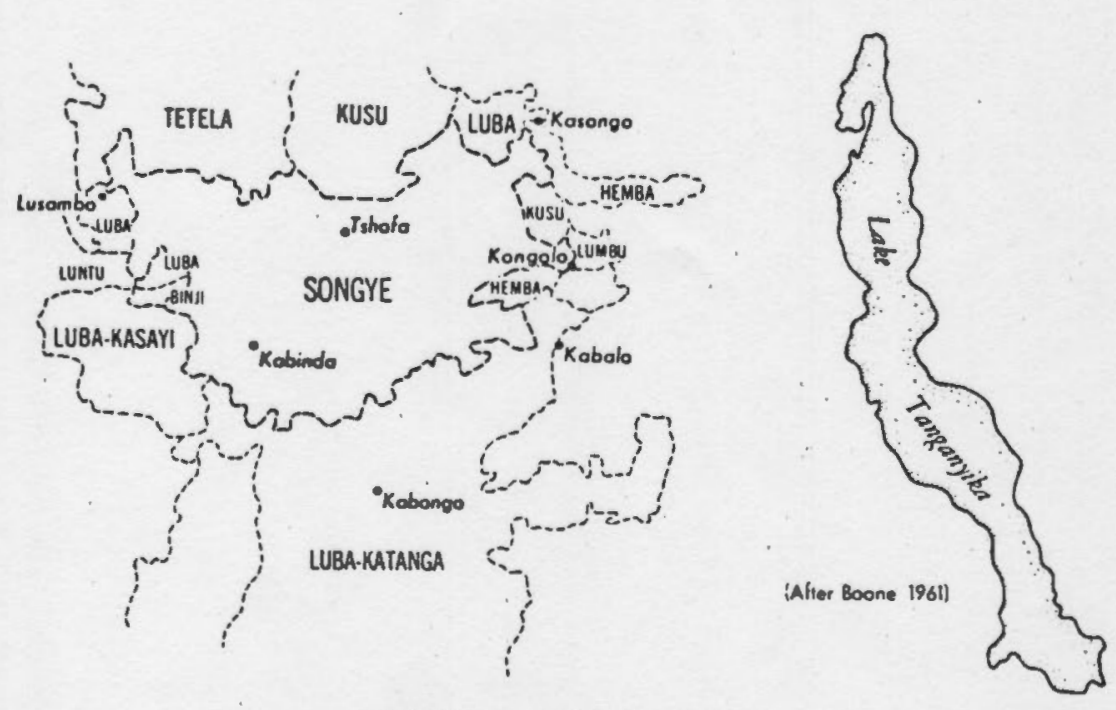

Neighbors of the Basongye 


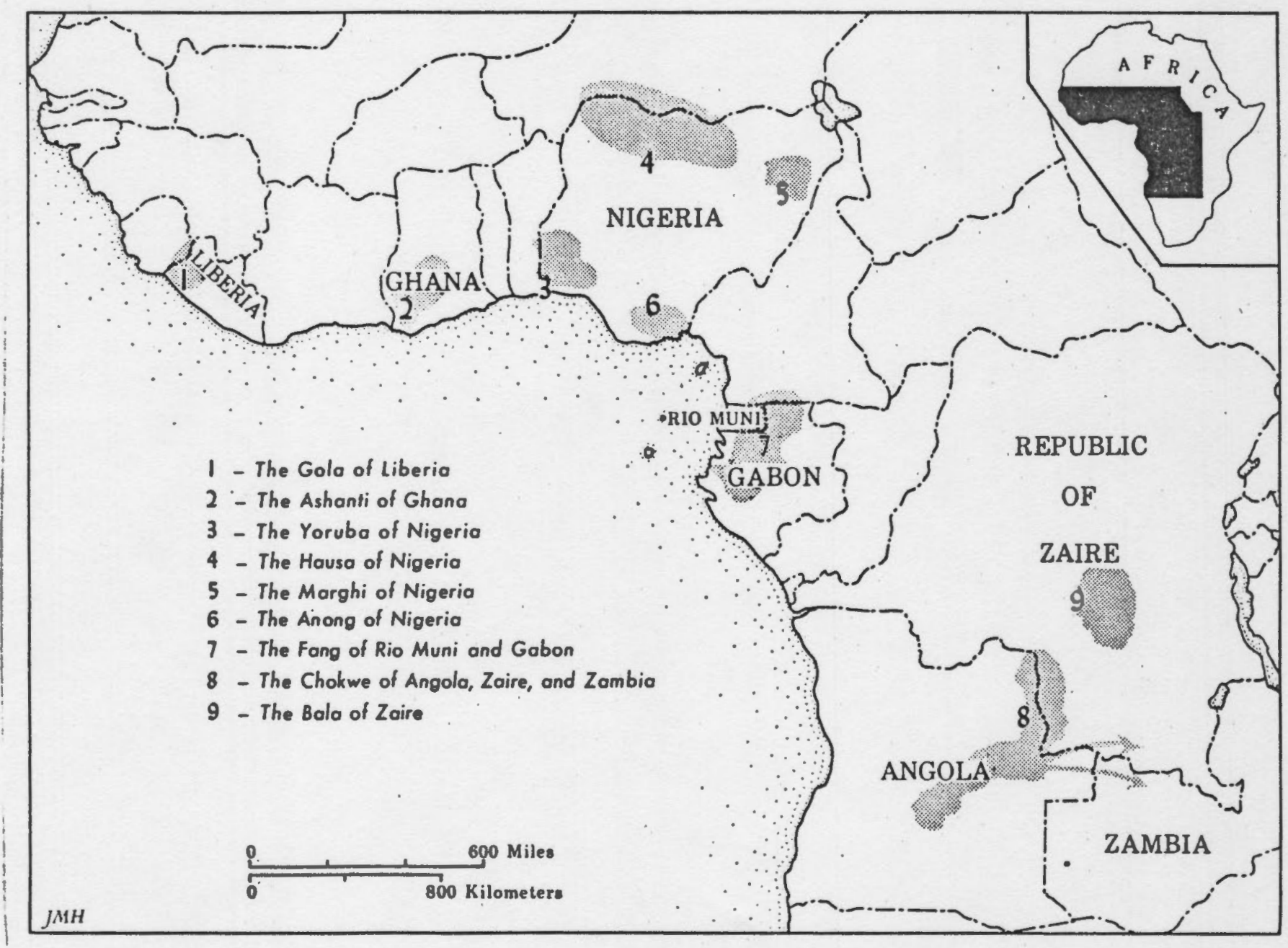




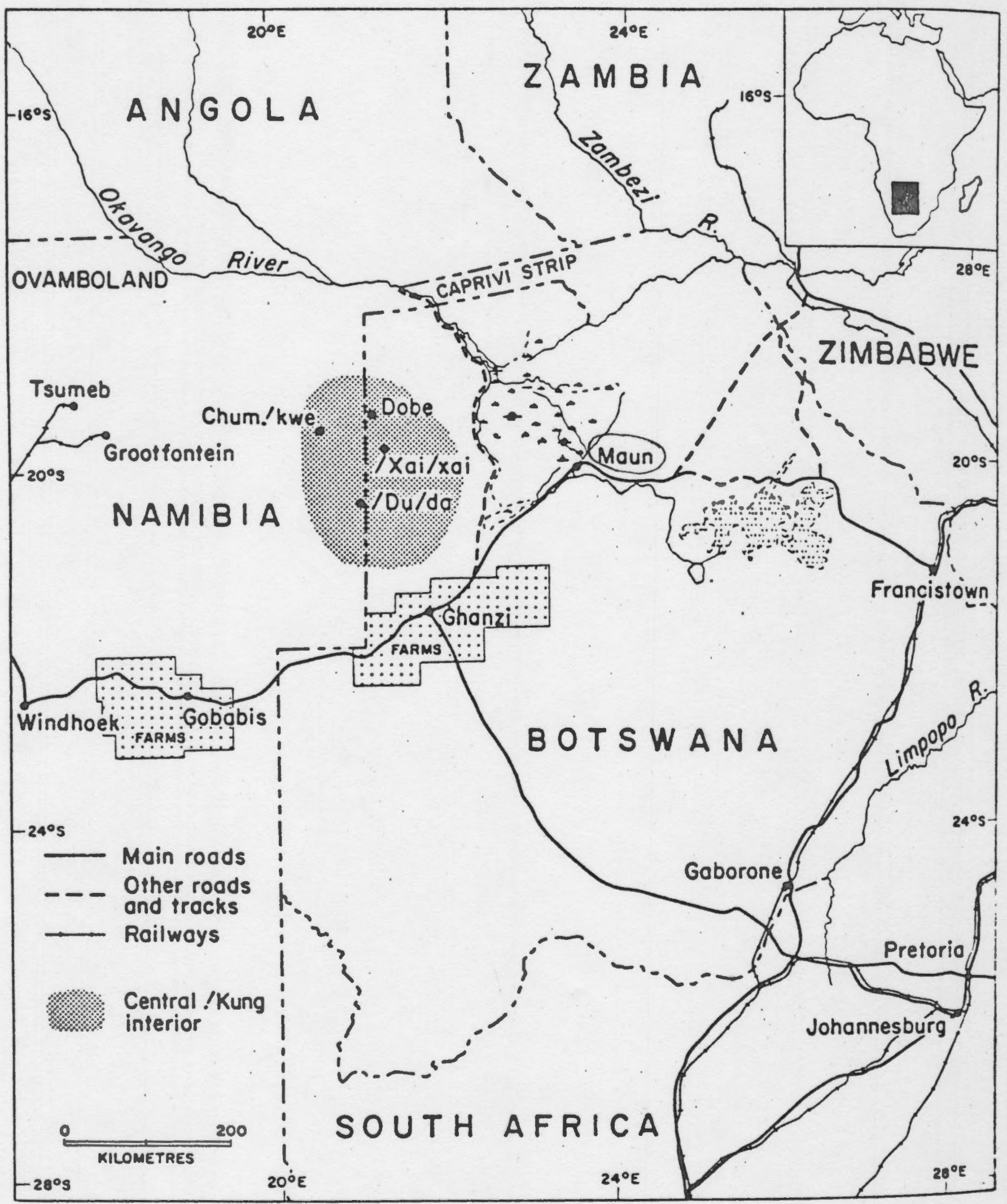

Figure 3.1. The Northwest Kalahari. 


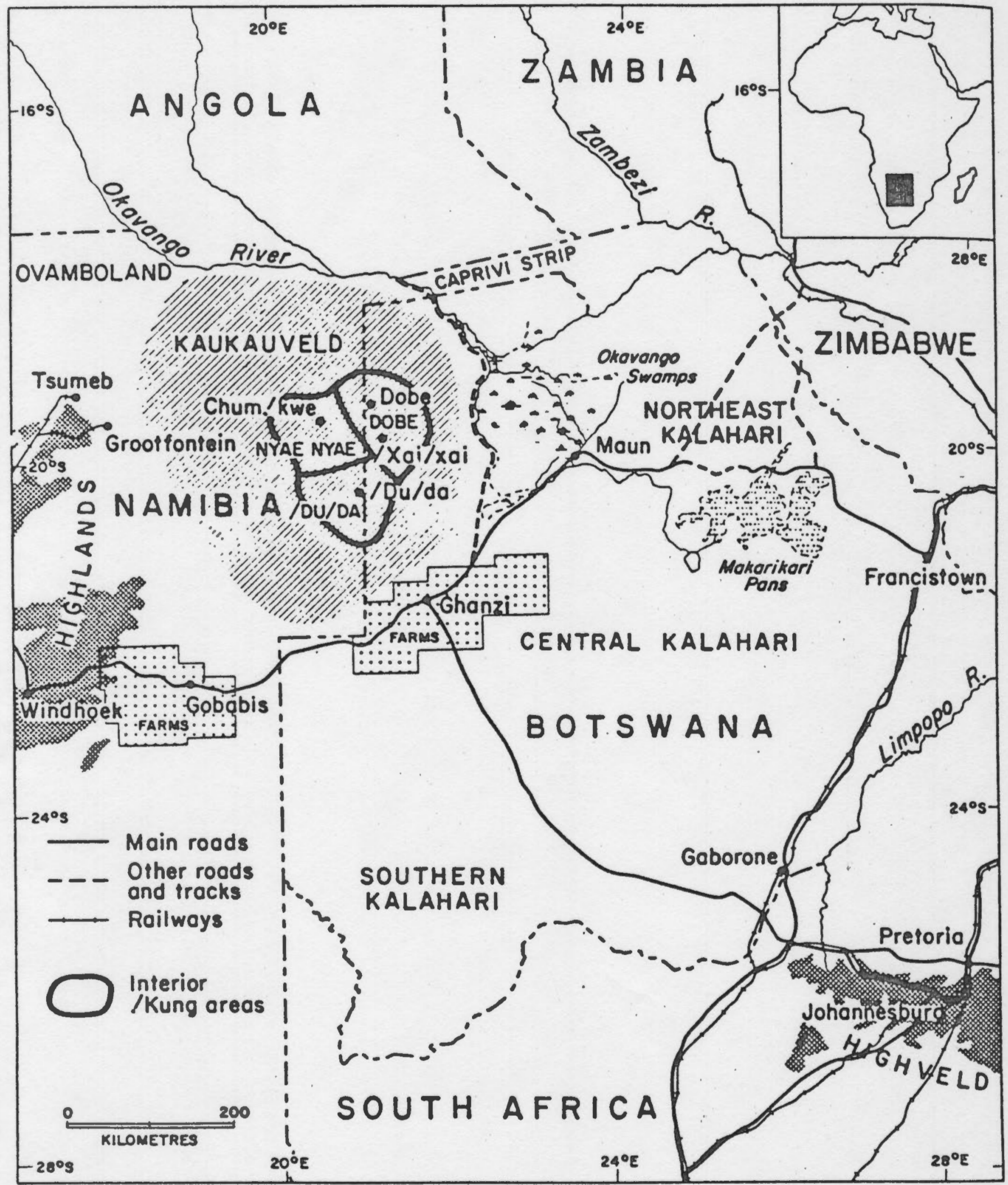

Figure 4.1. The Kaukauveld, showing the Dobe and $/ \mathrm{Du} / \mathrm{da}$ areas. 


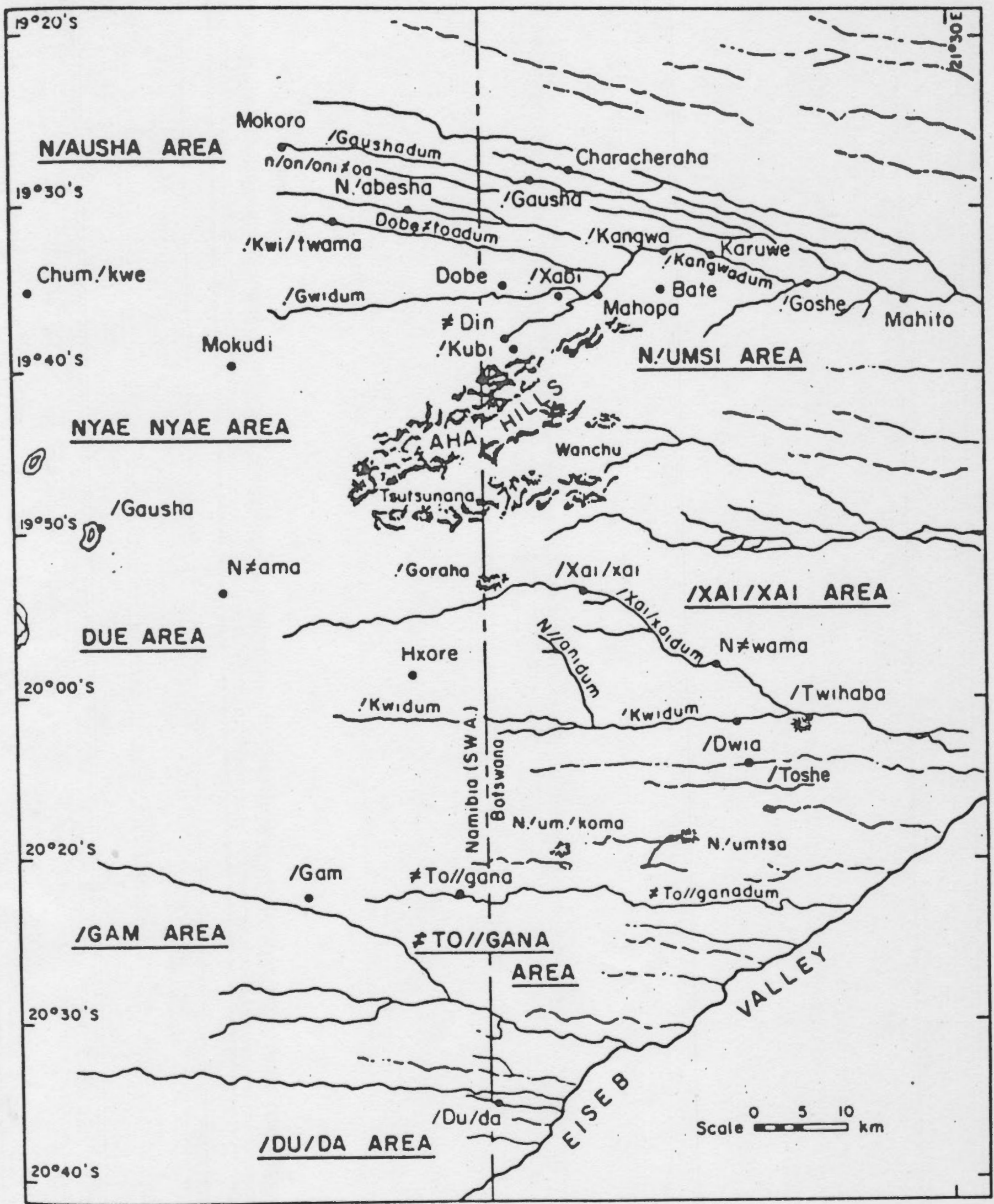

Figure 3.2. The Dobe area. 


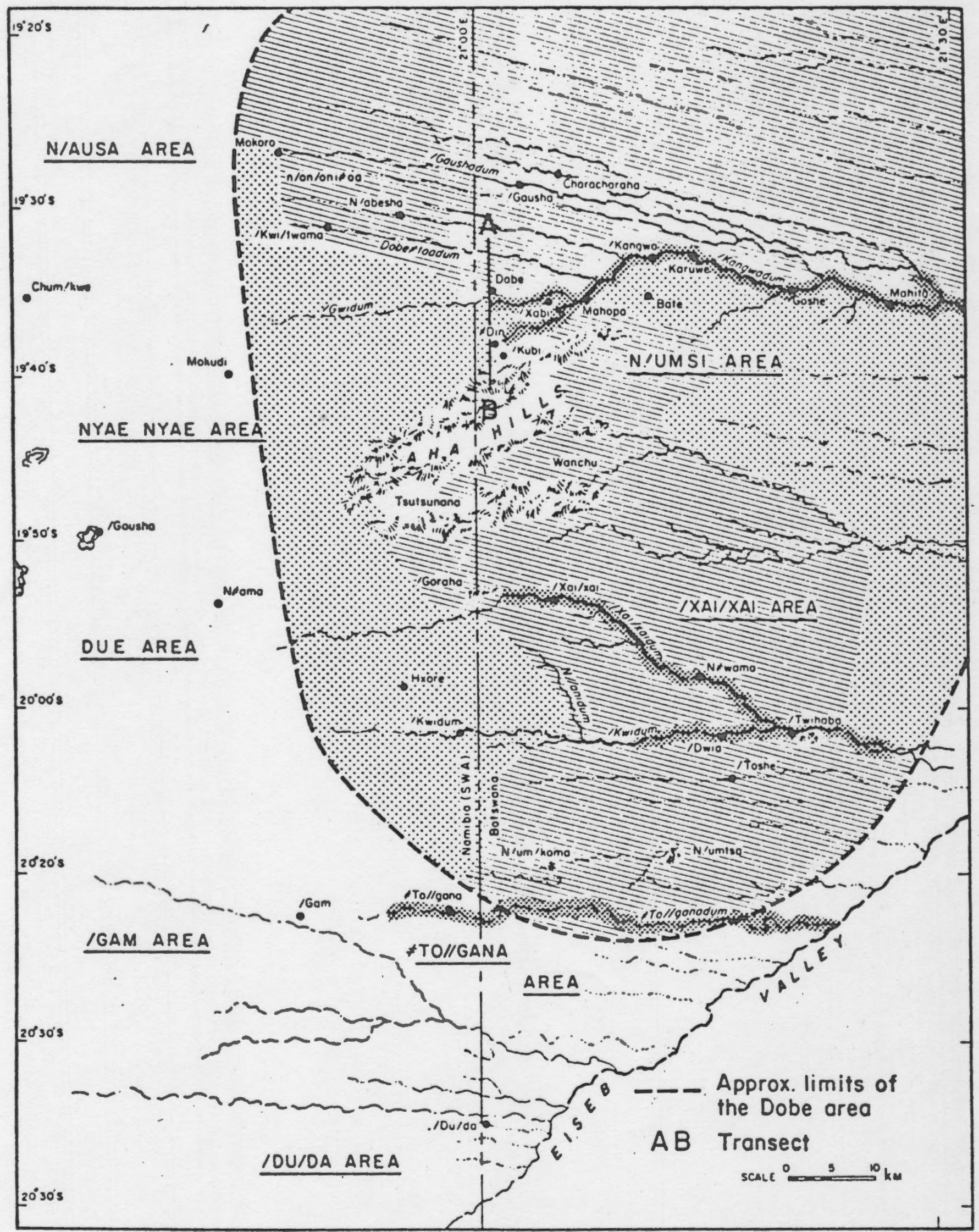

$\approx$ Dune-Molapo

Flots Lower Molopo/ Hardpon river volleys

Figure 4.2. Physiography of the Dobe area. 


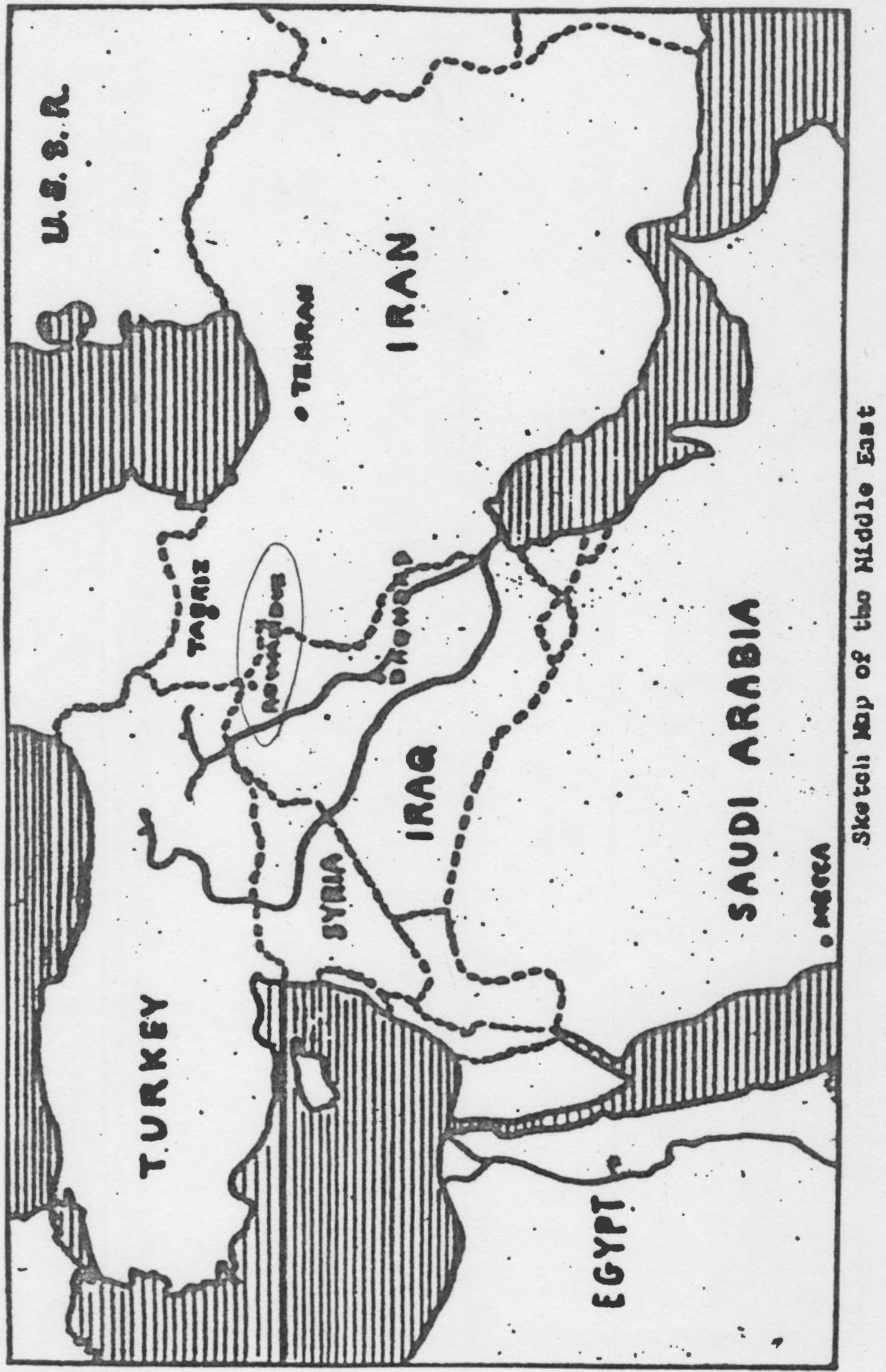




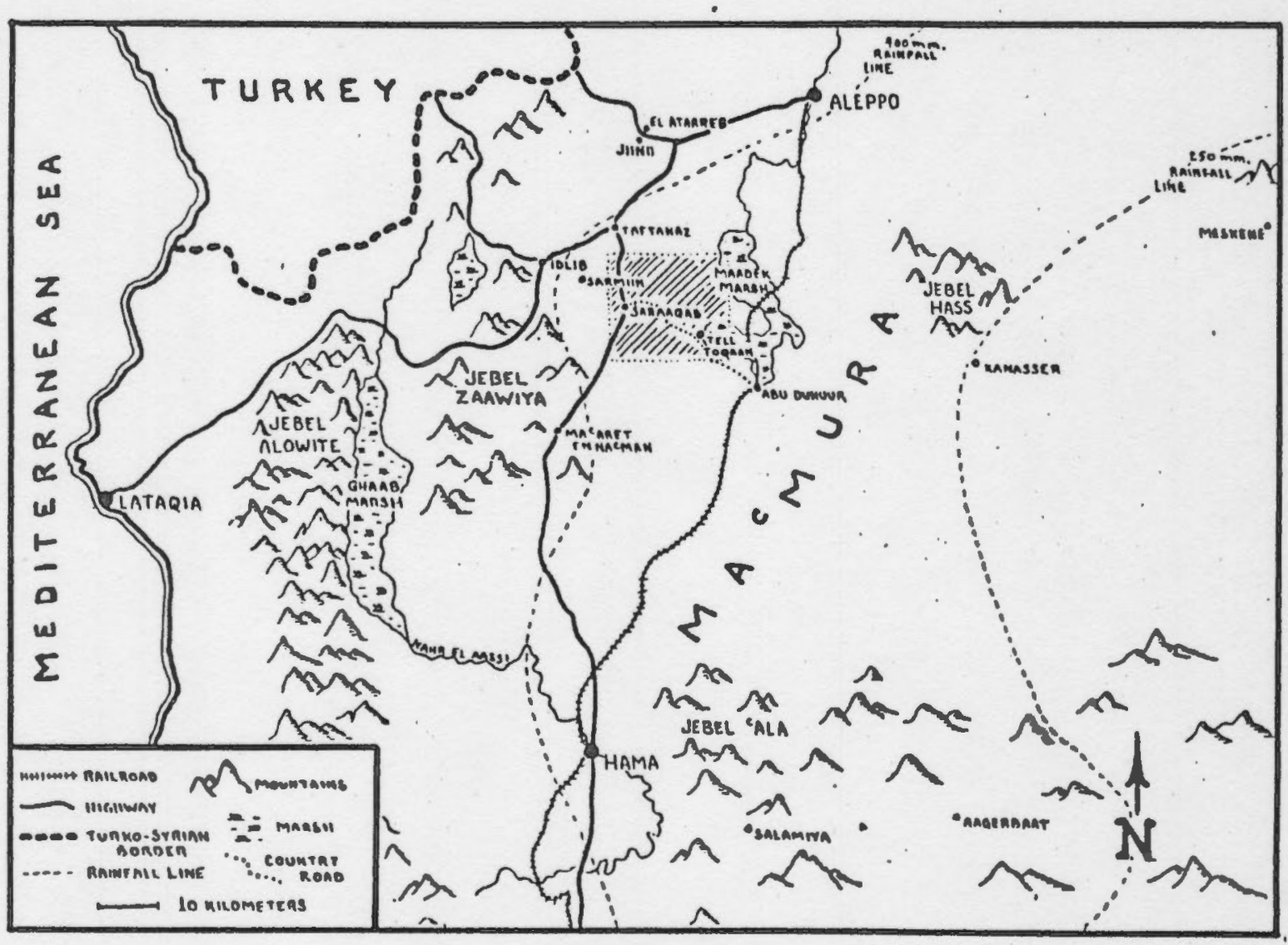

Northwest Syria. 


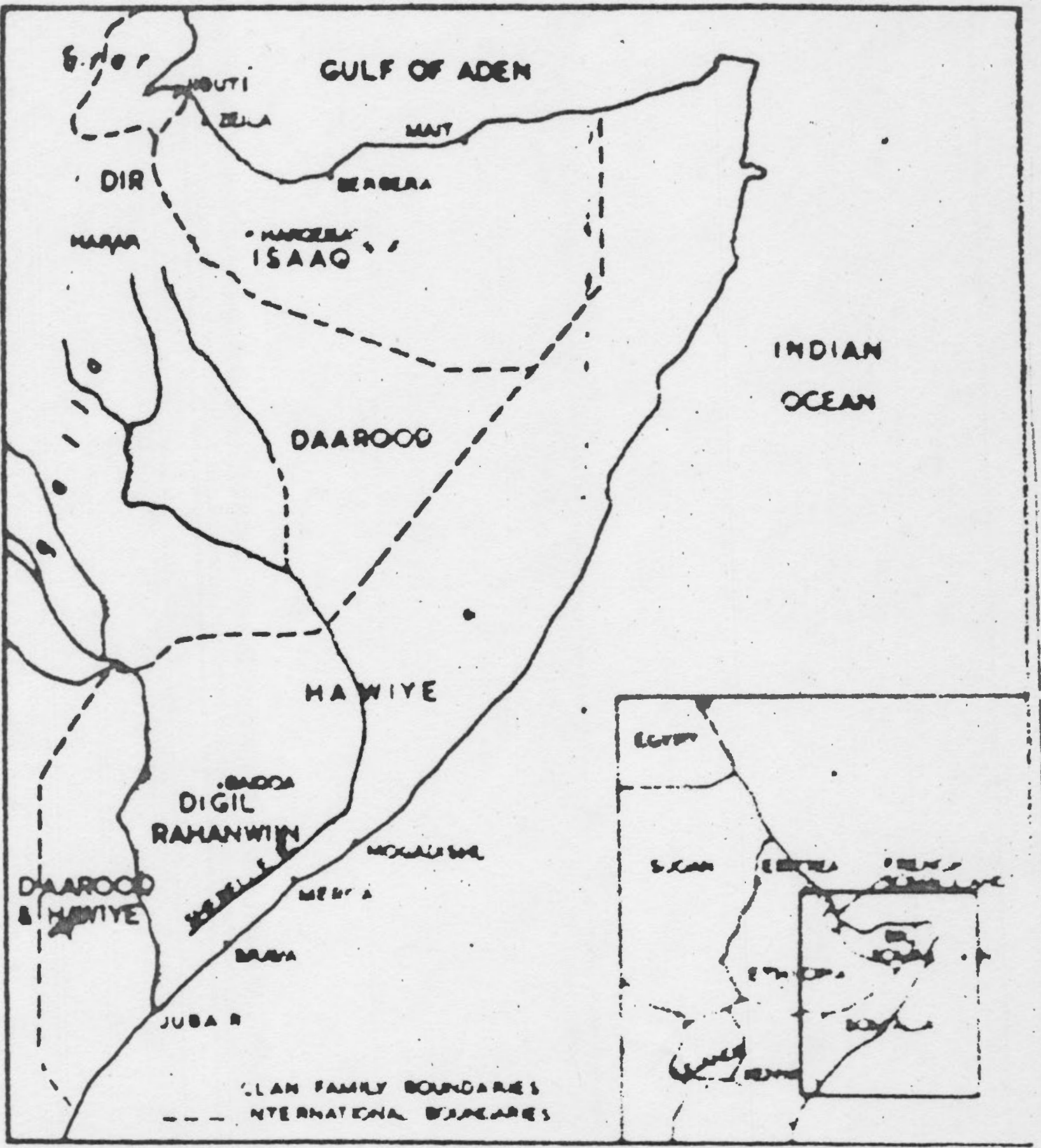

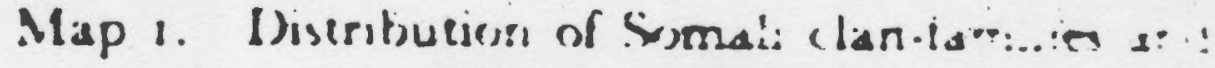
ronesgucuss peupics. 


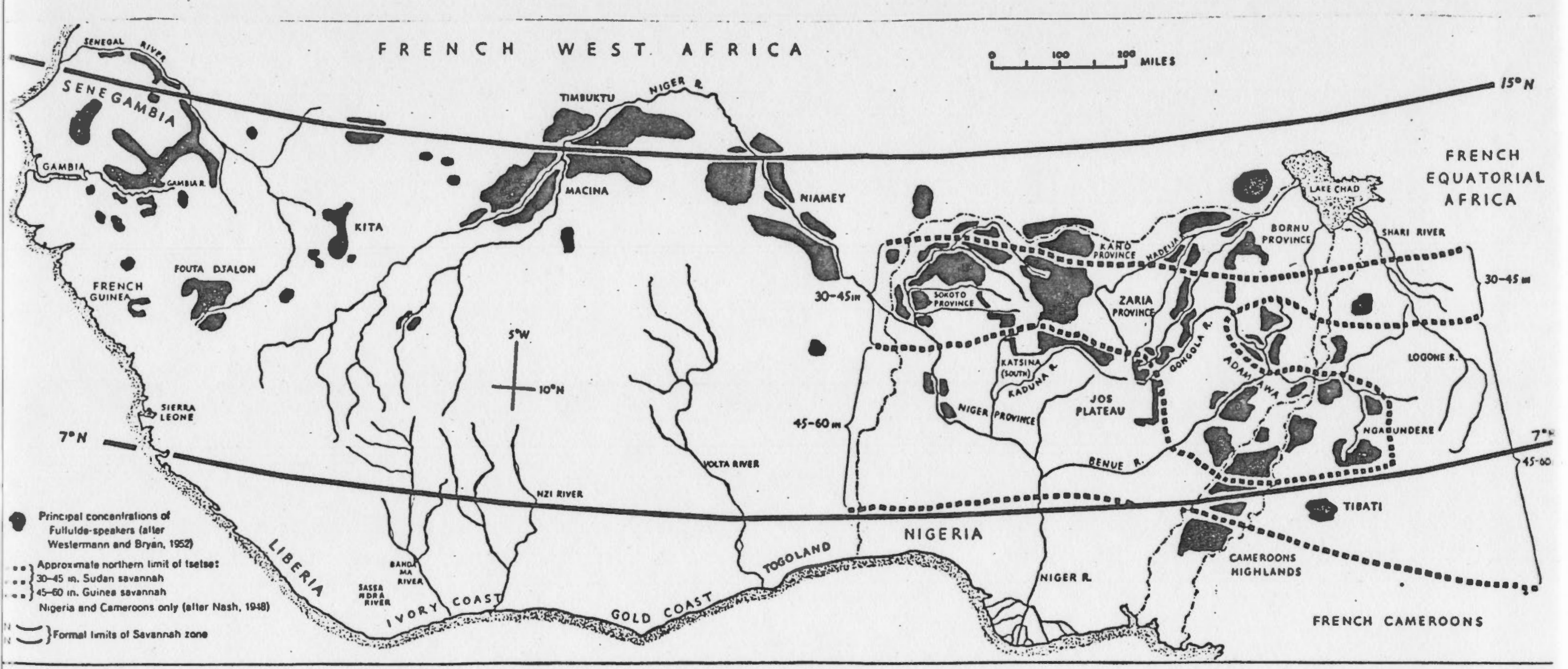

!Fto. 1. Distribution of Fulani in relation to the Savannah Zone of West Africa 


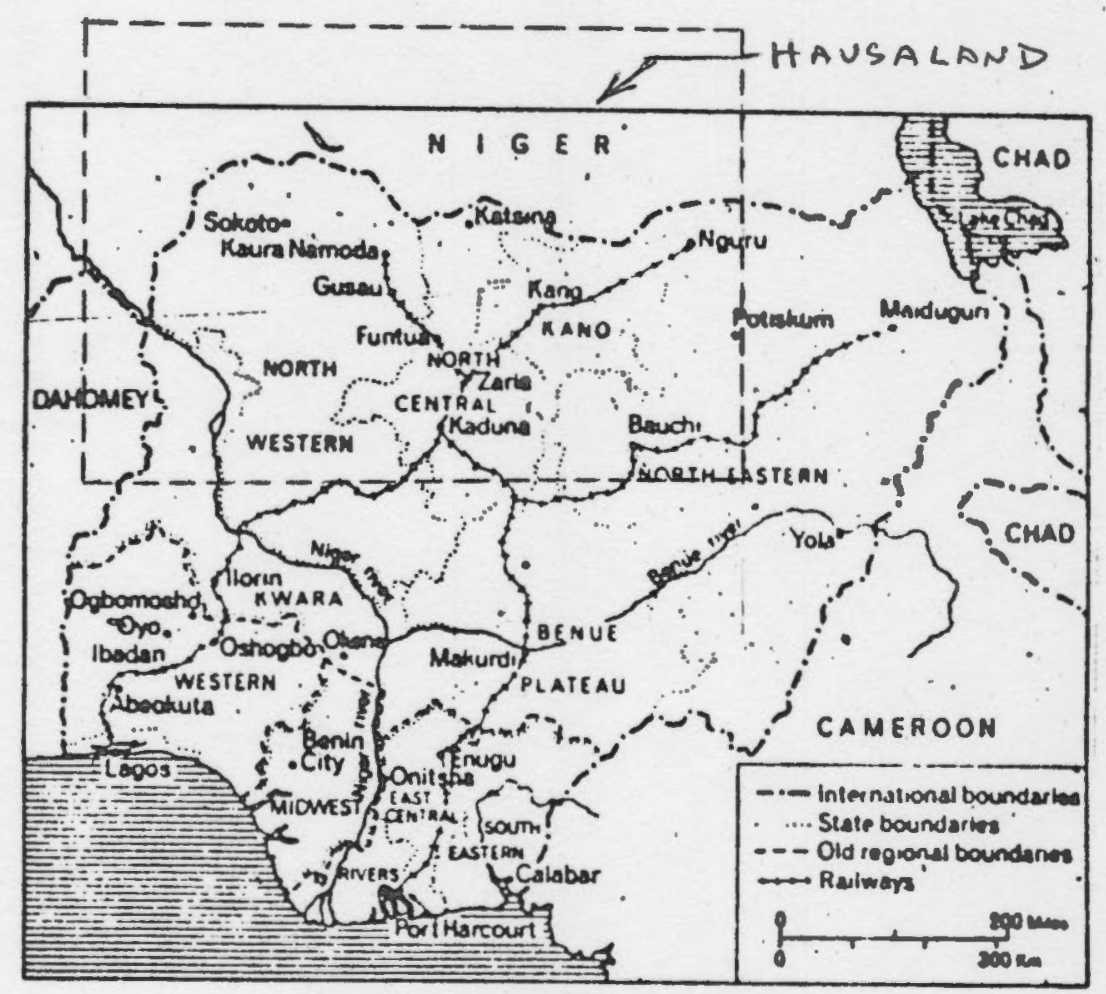

Mep of Nipari, showing atce bounderia 


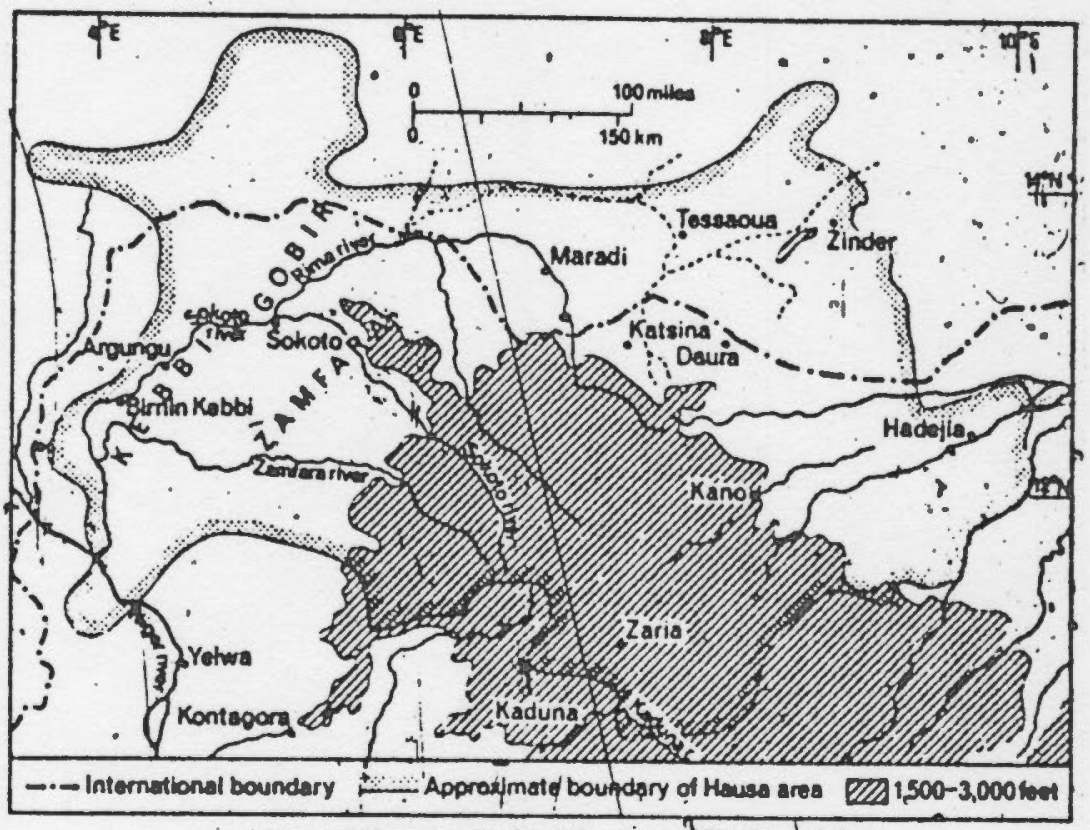

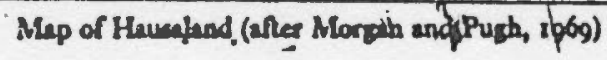




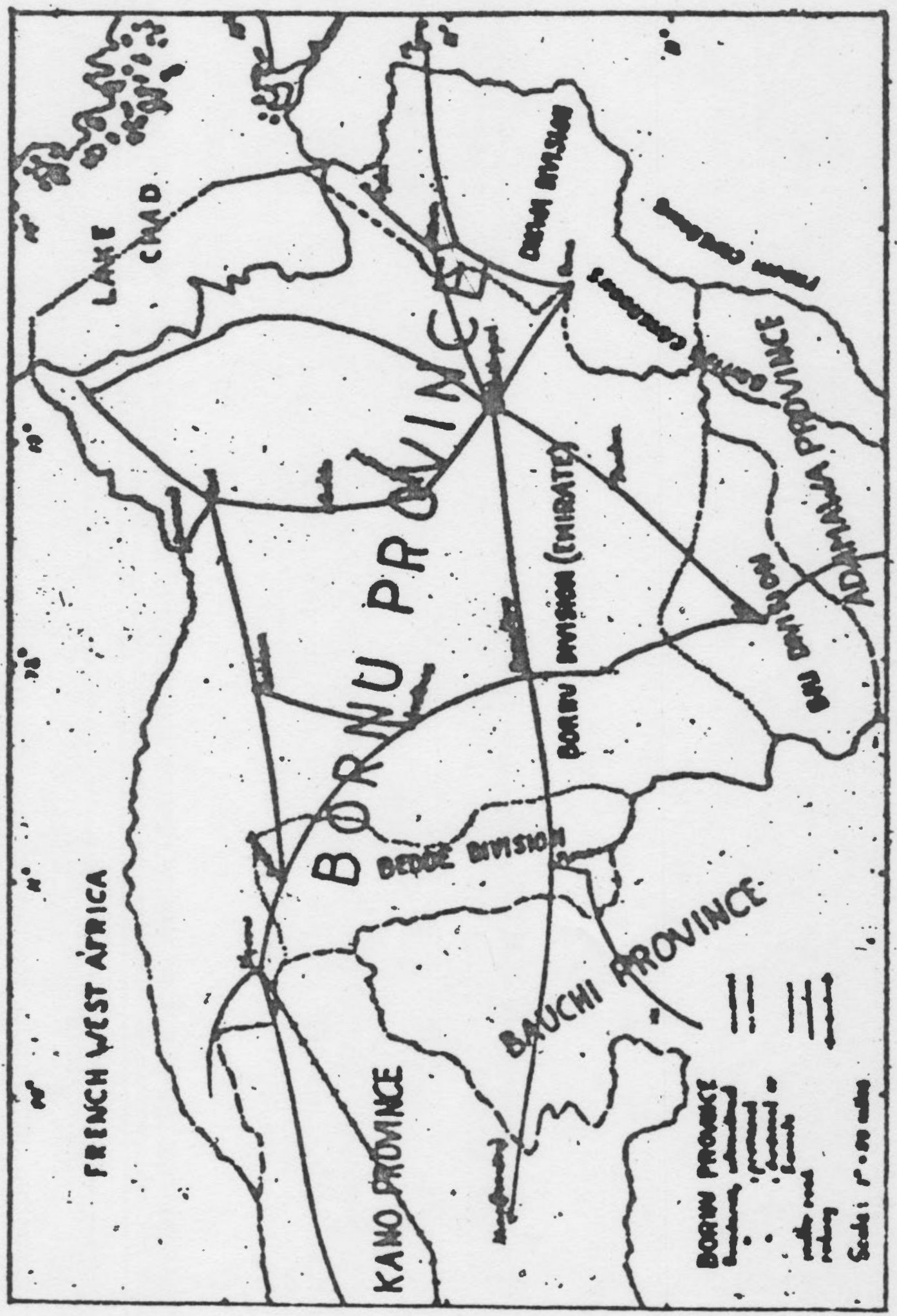




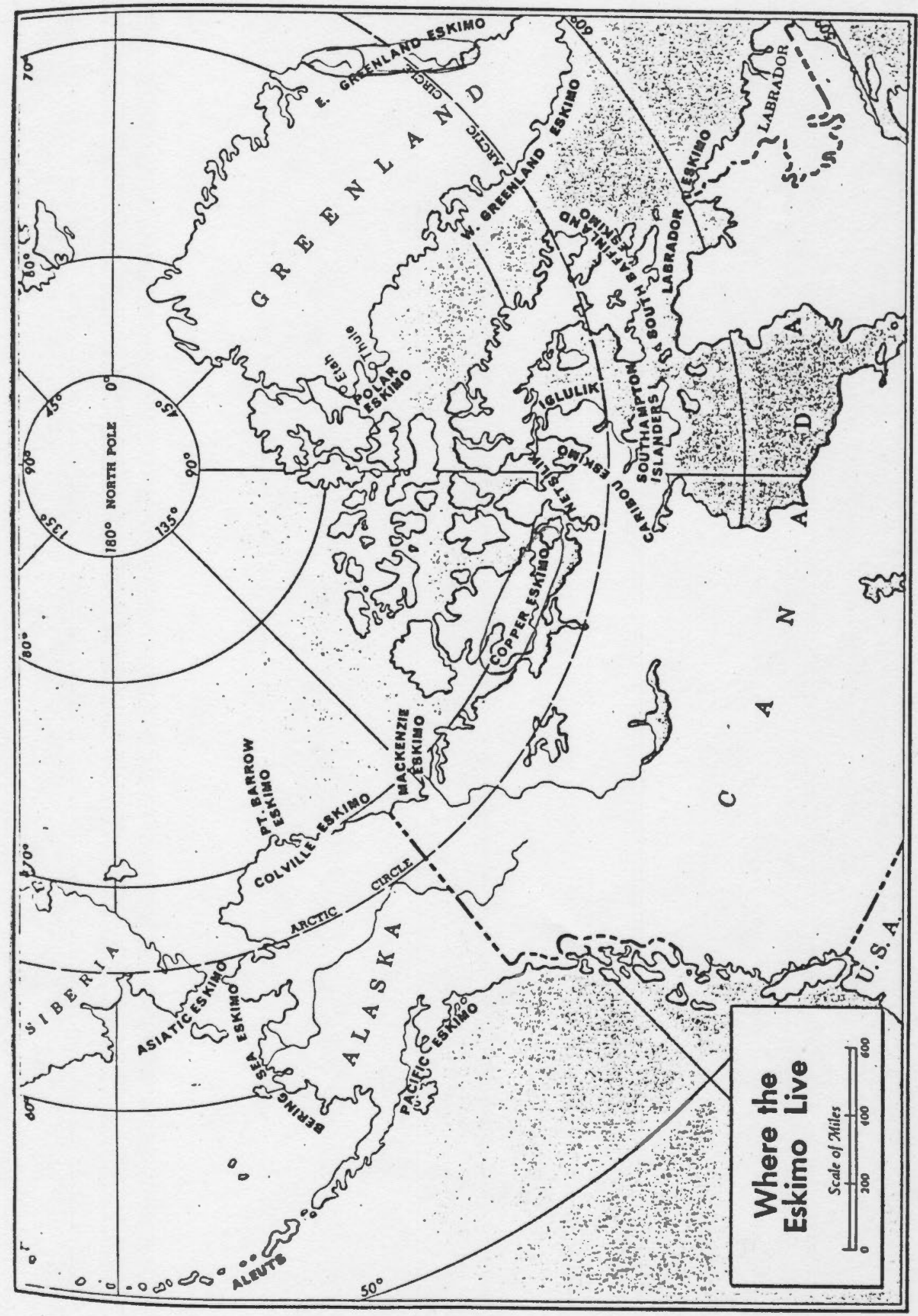




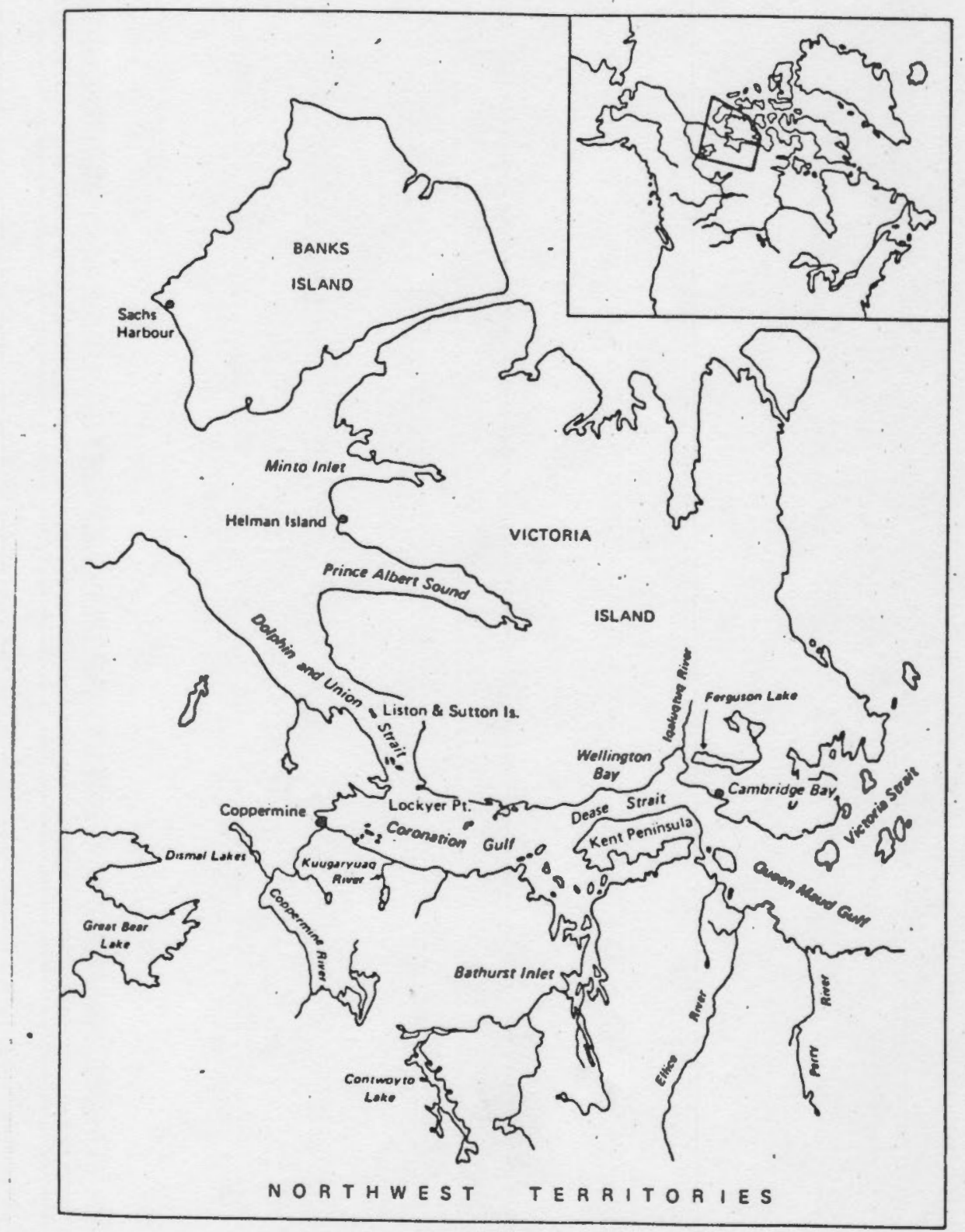

Figure 1-1. Area of the Copper Eskimo. 


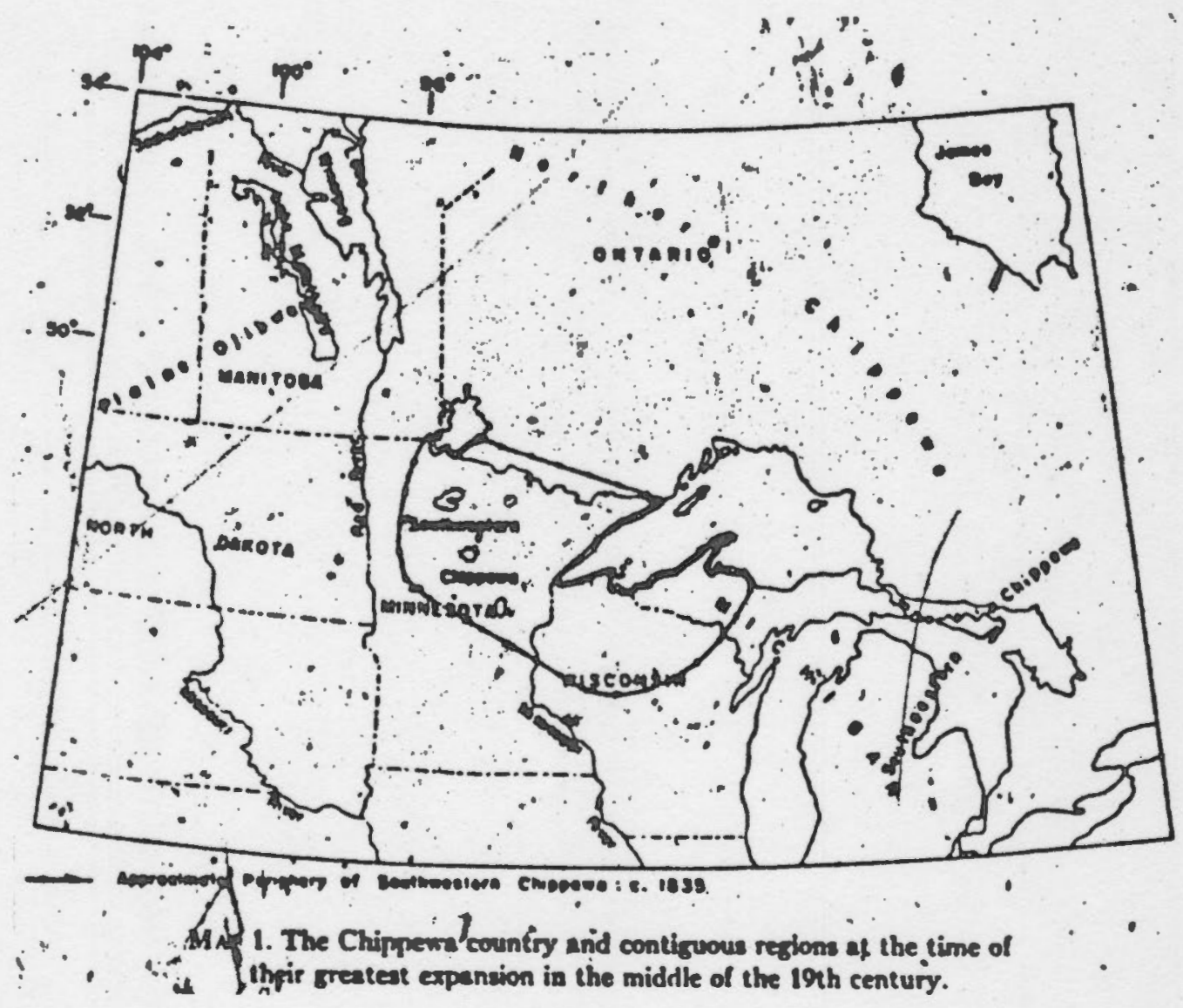




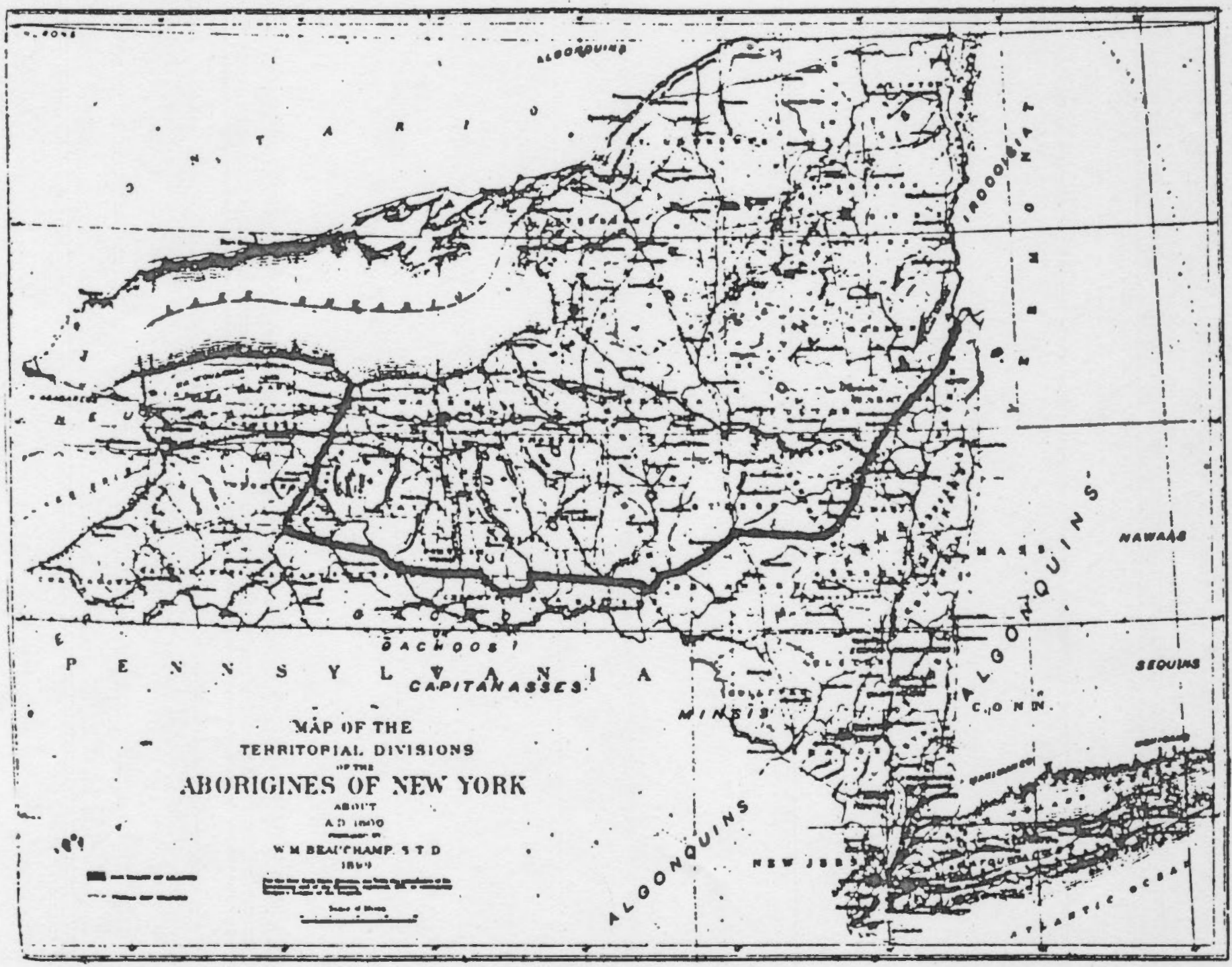




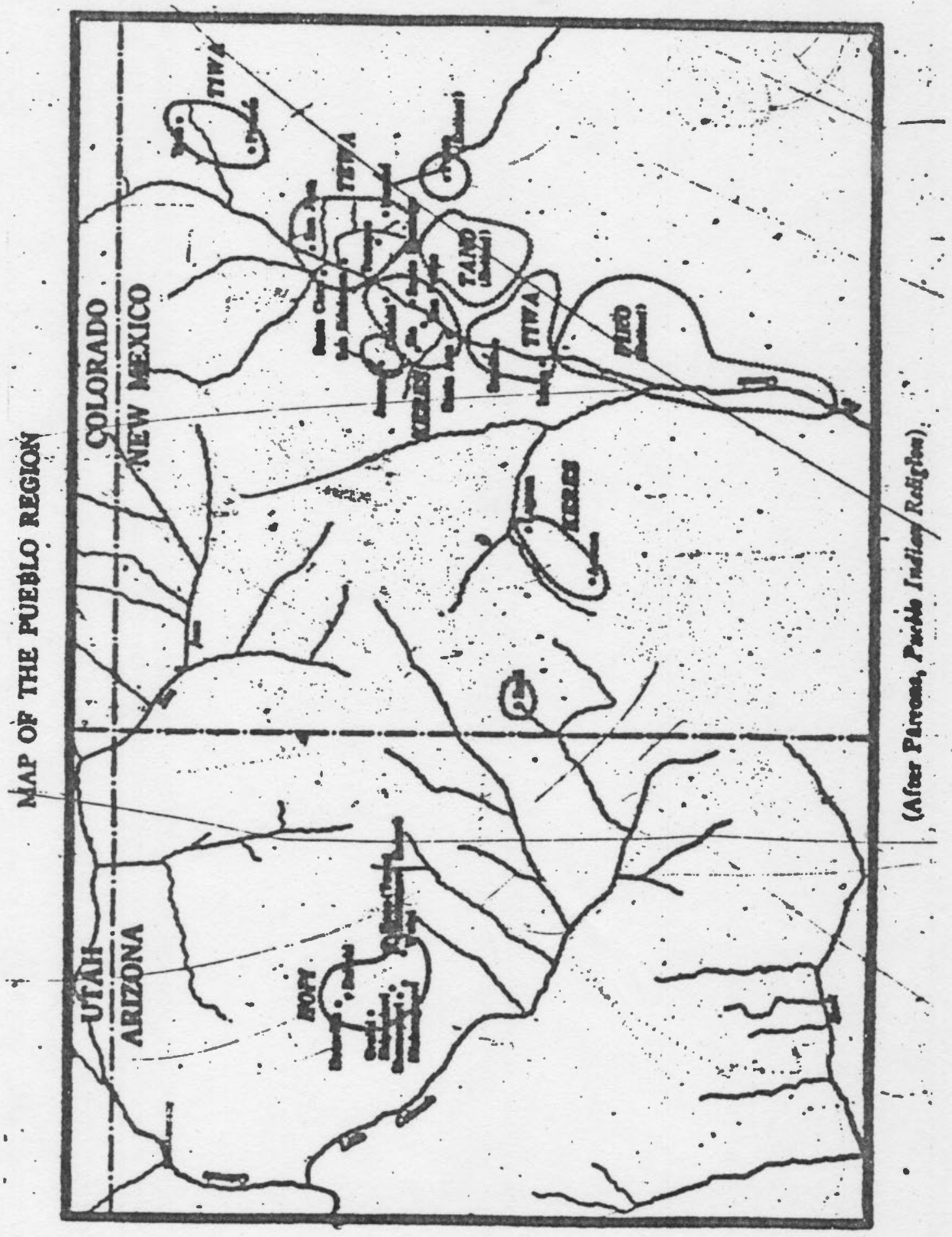




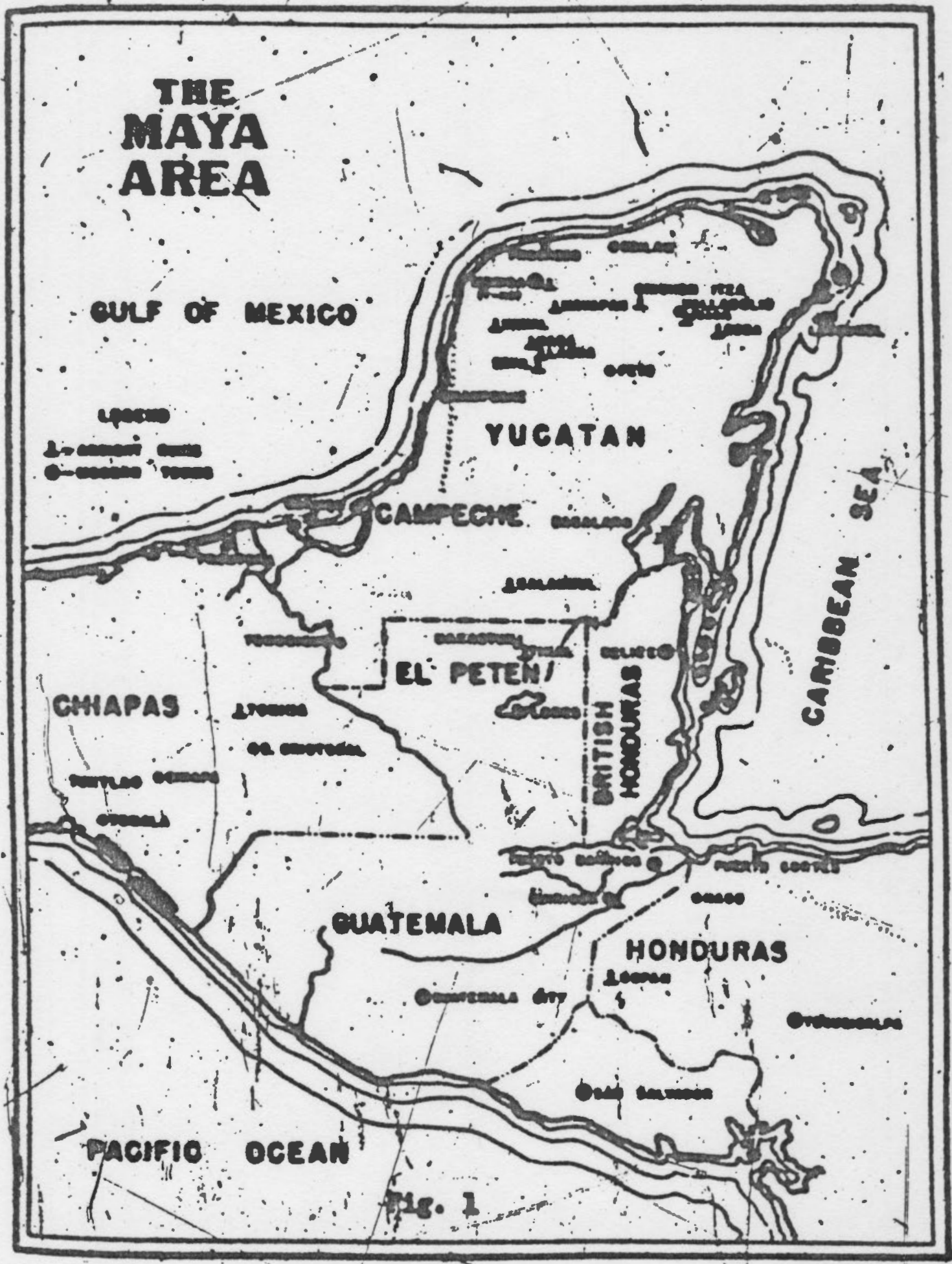




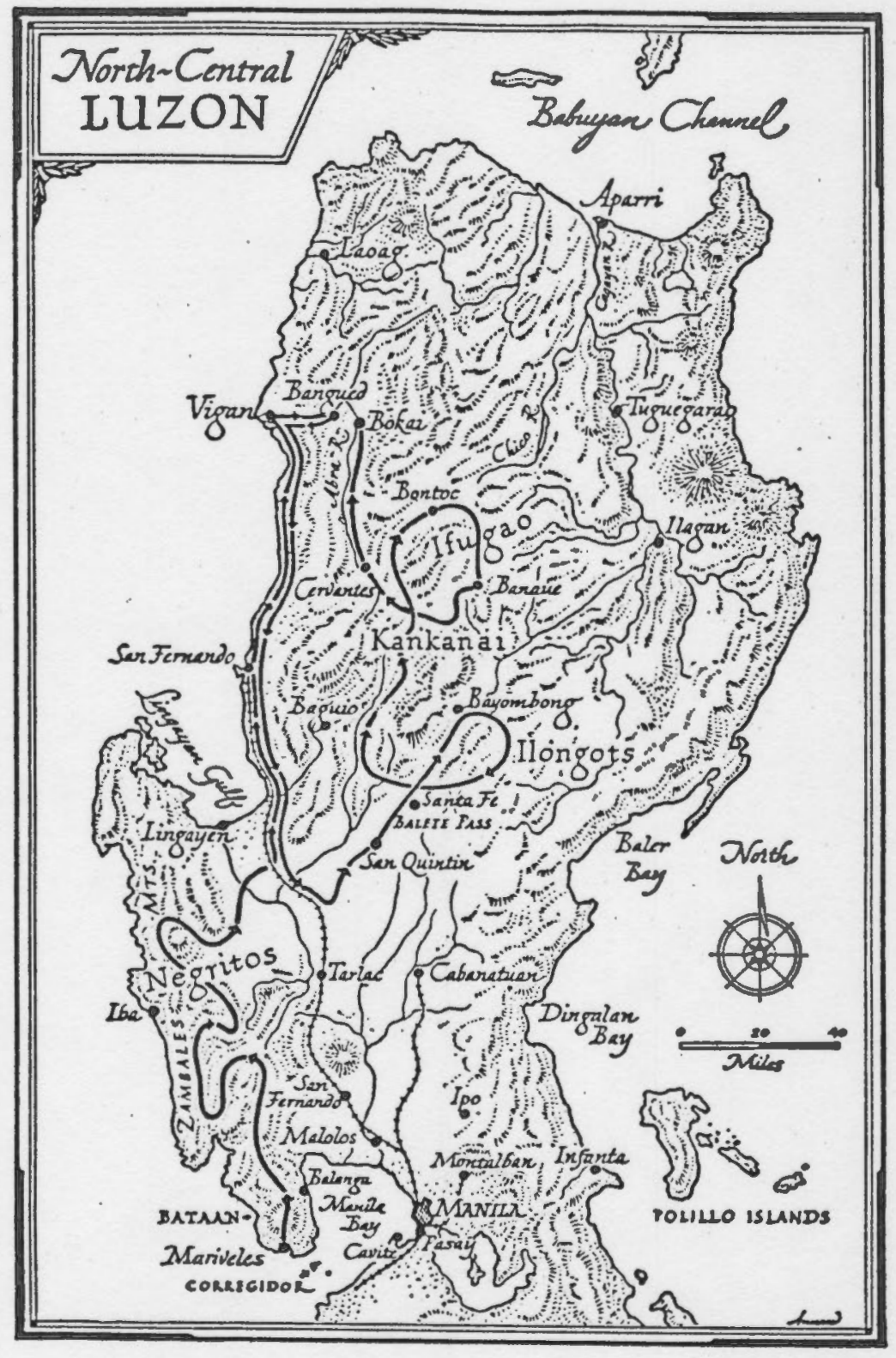




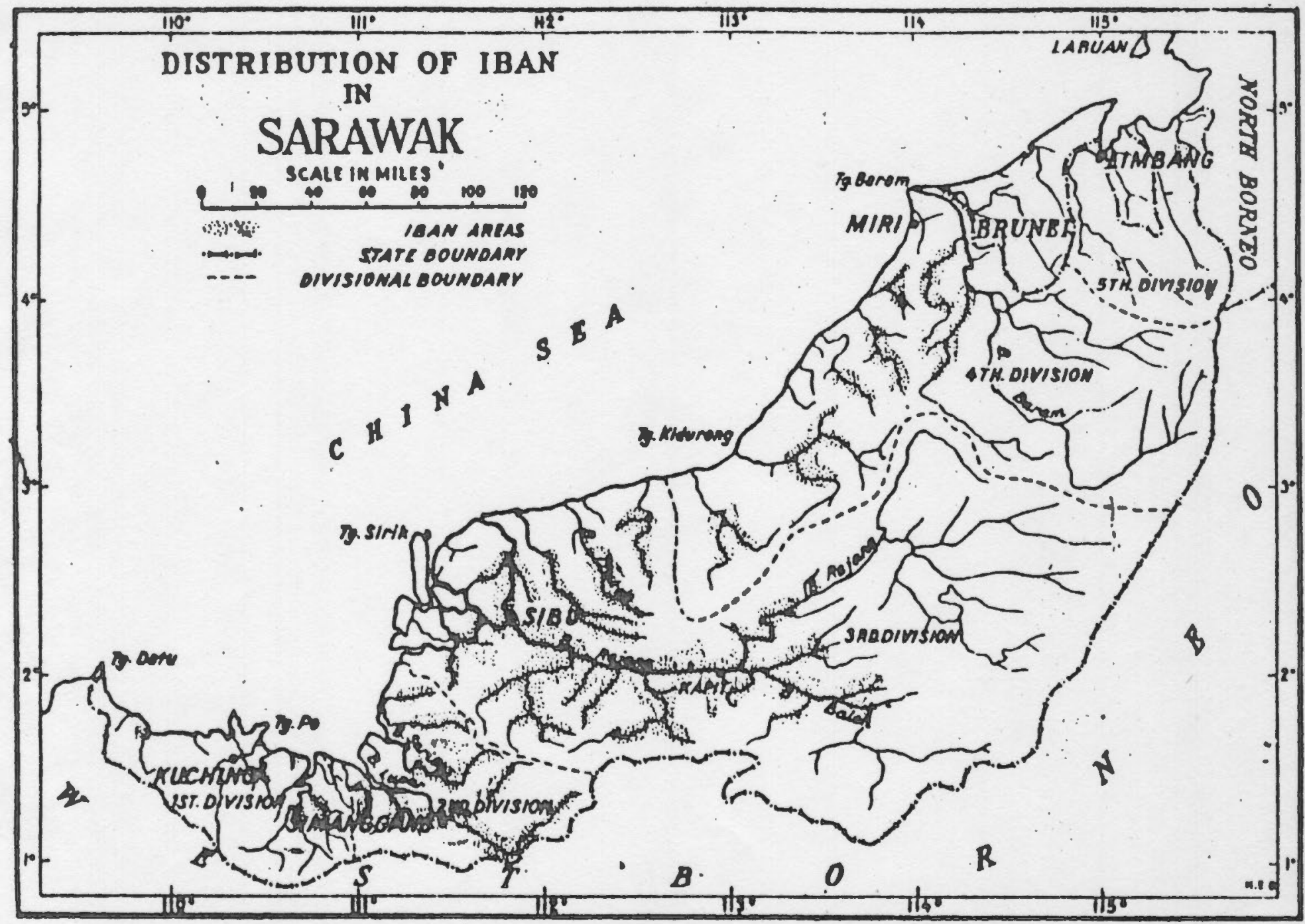

Sketch Map 2. Showing the Distribuicion of the Iber is Surtwit. (Based on the Cearus of 1947) 


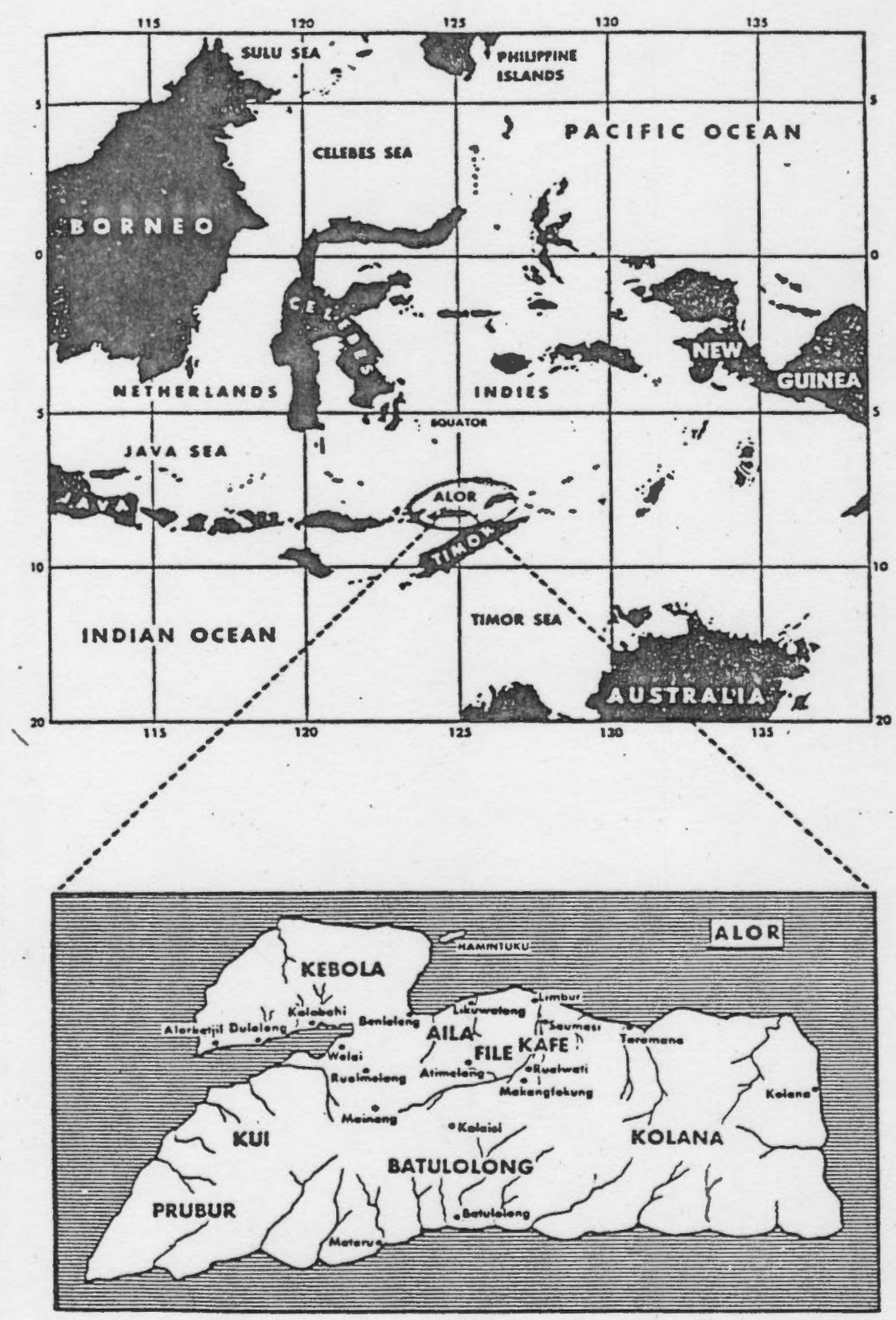




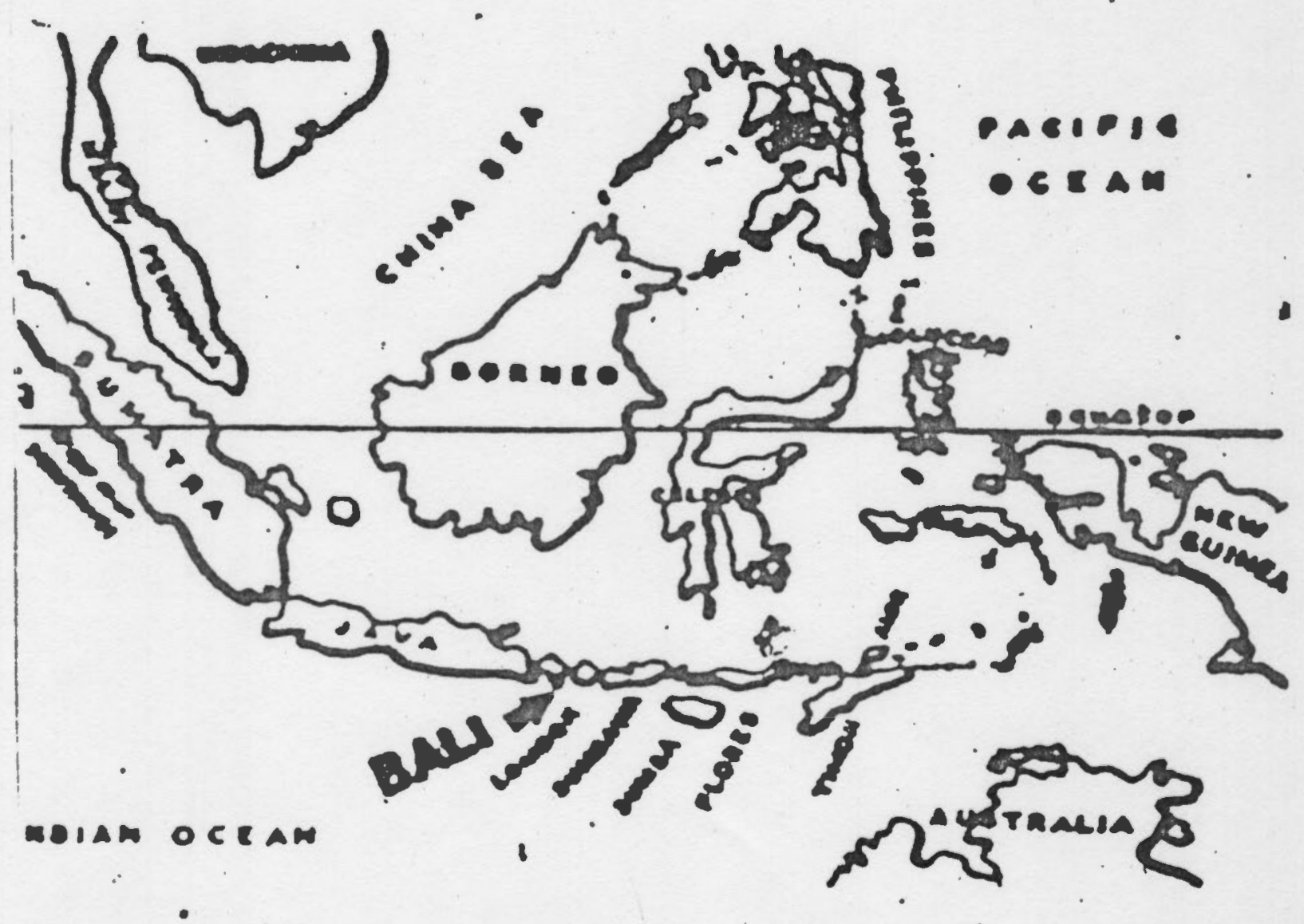




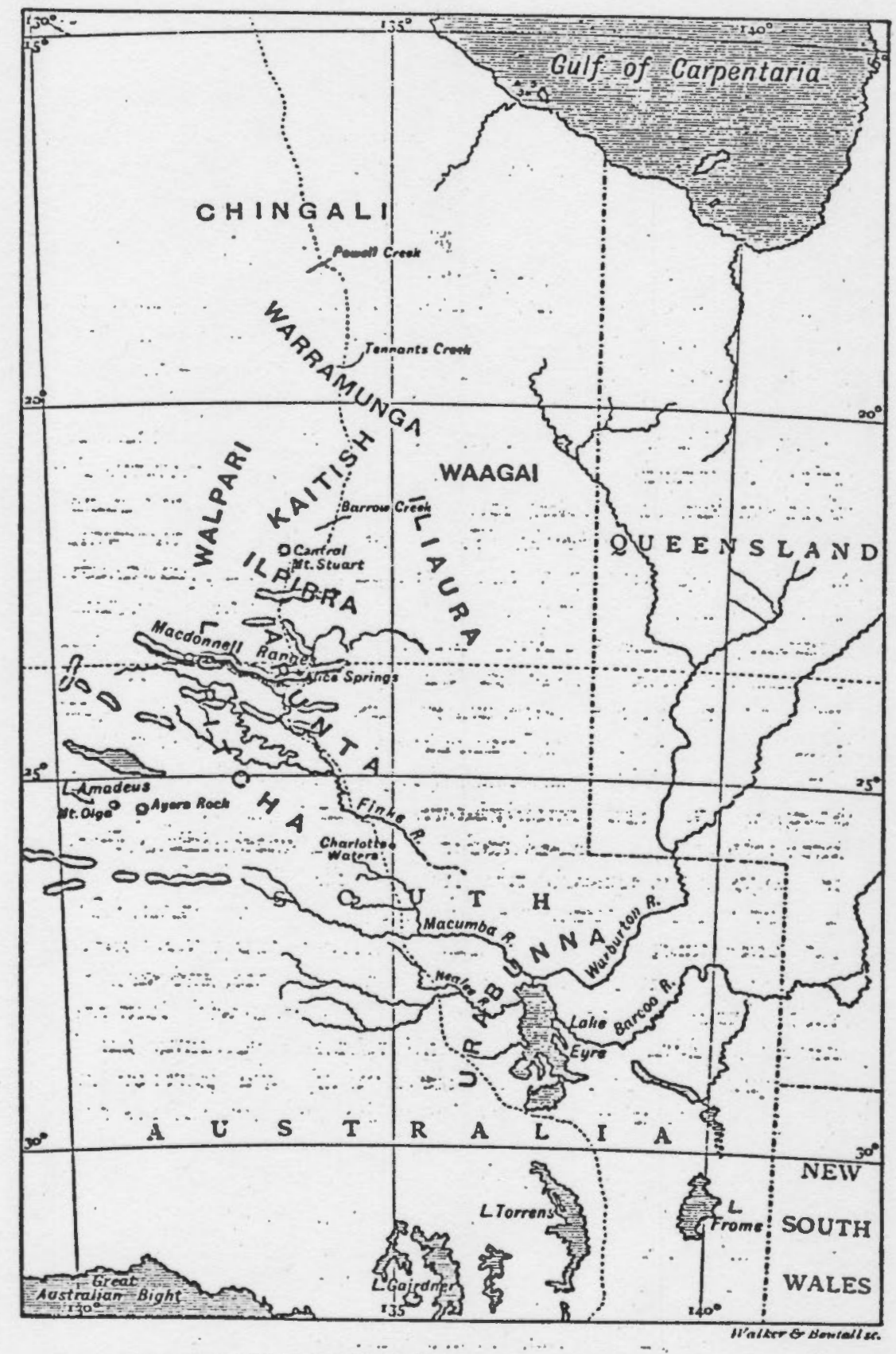

FIG. 1. -OLTLINE MAP OF THE CENTRAC AREA, SHOWING THE DISTRIBUTION OF THE TRIEES REFERRED TO. 


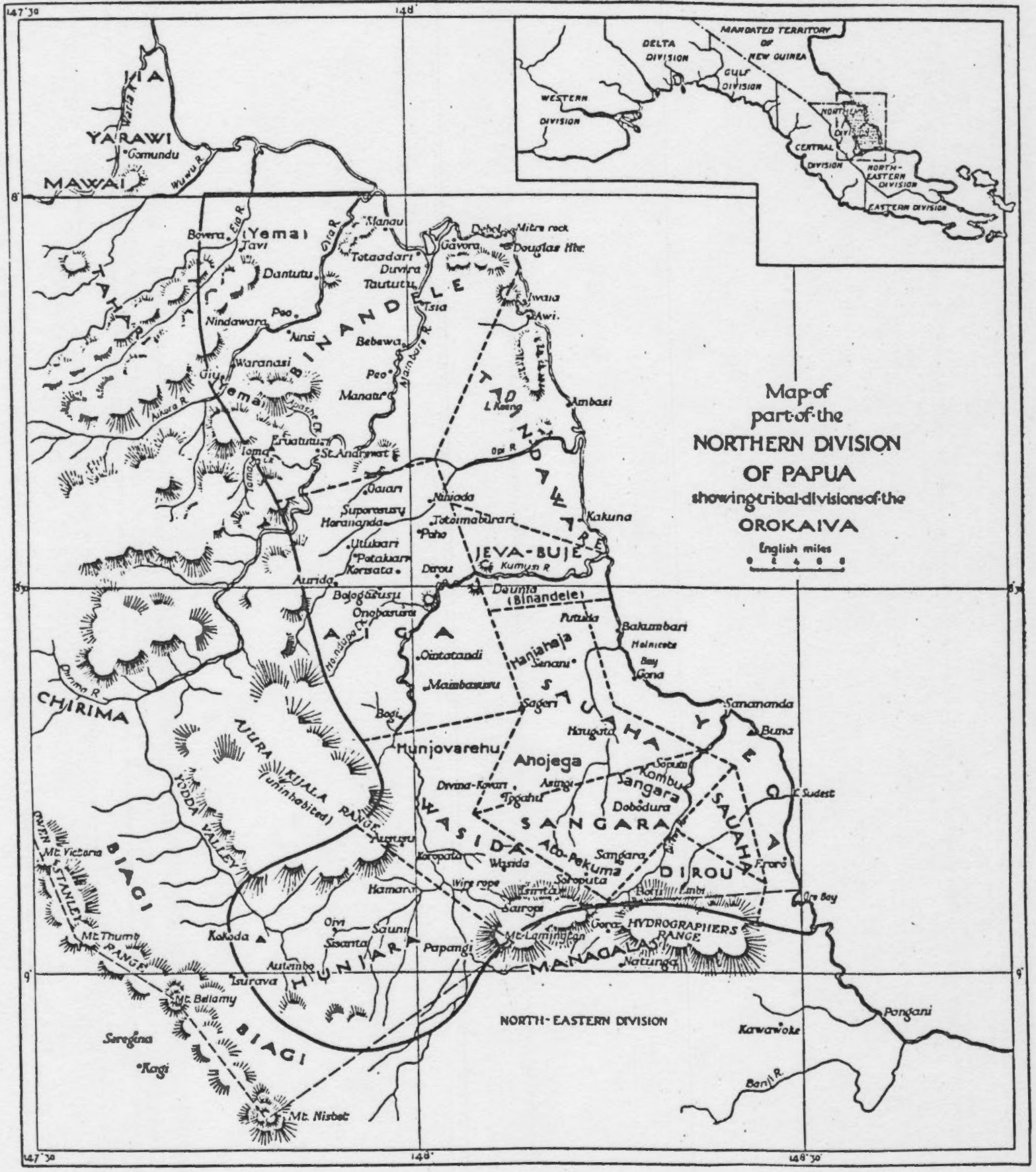




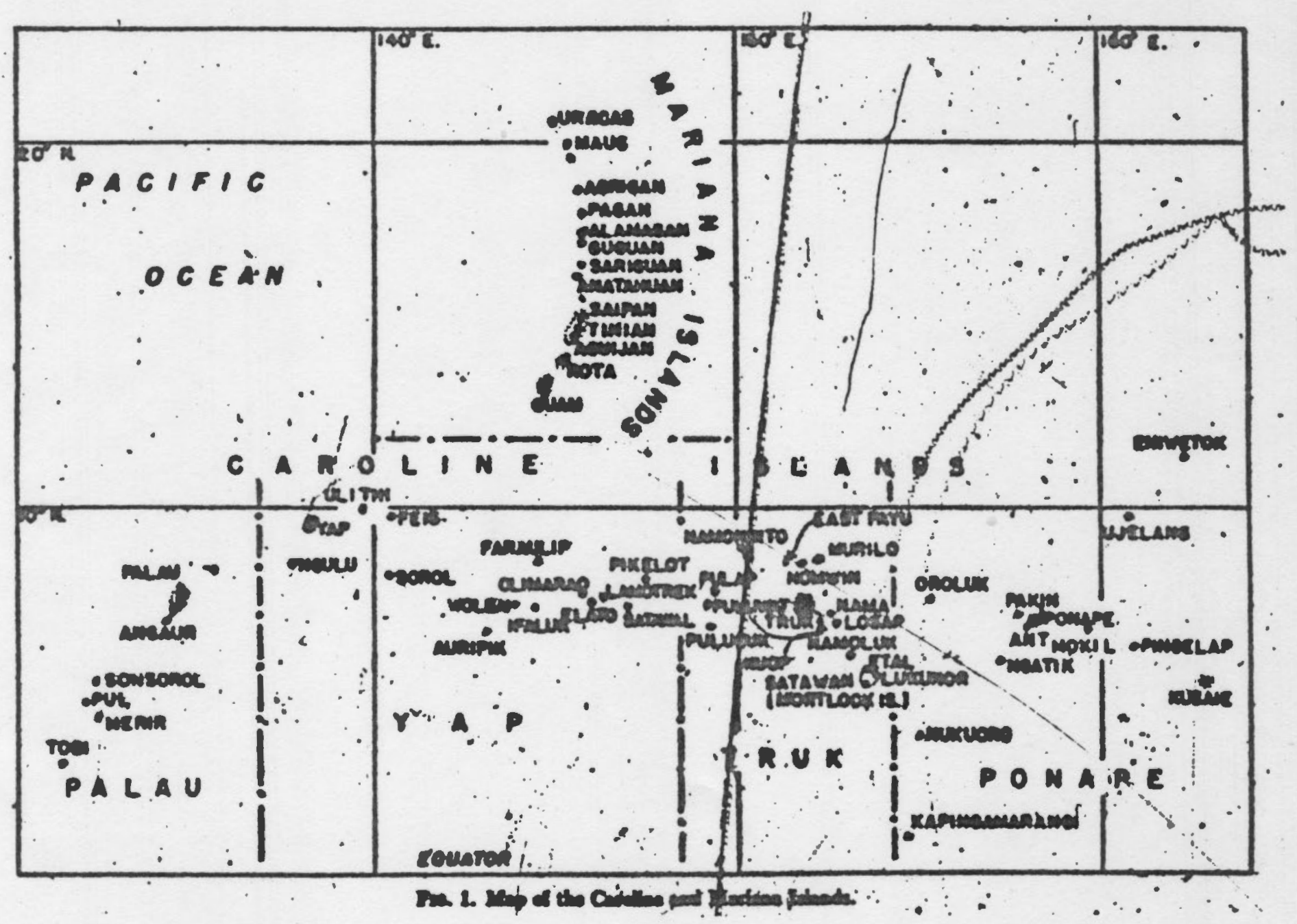




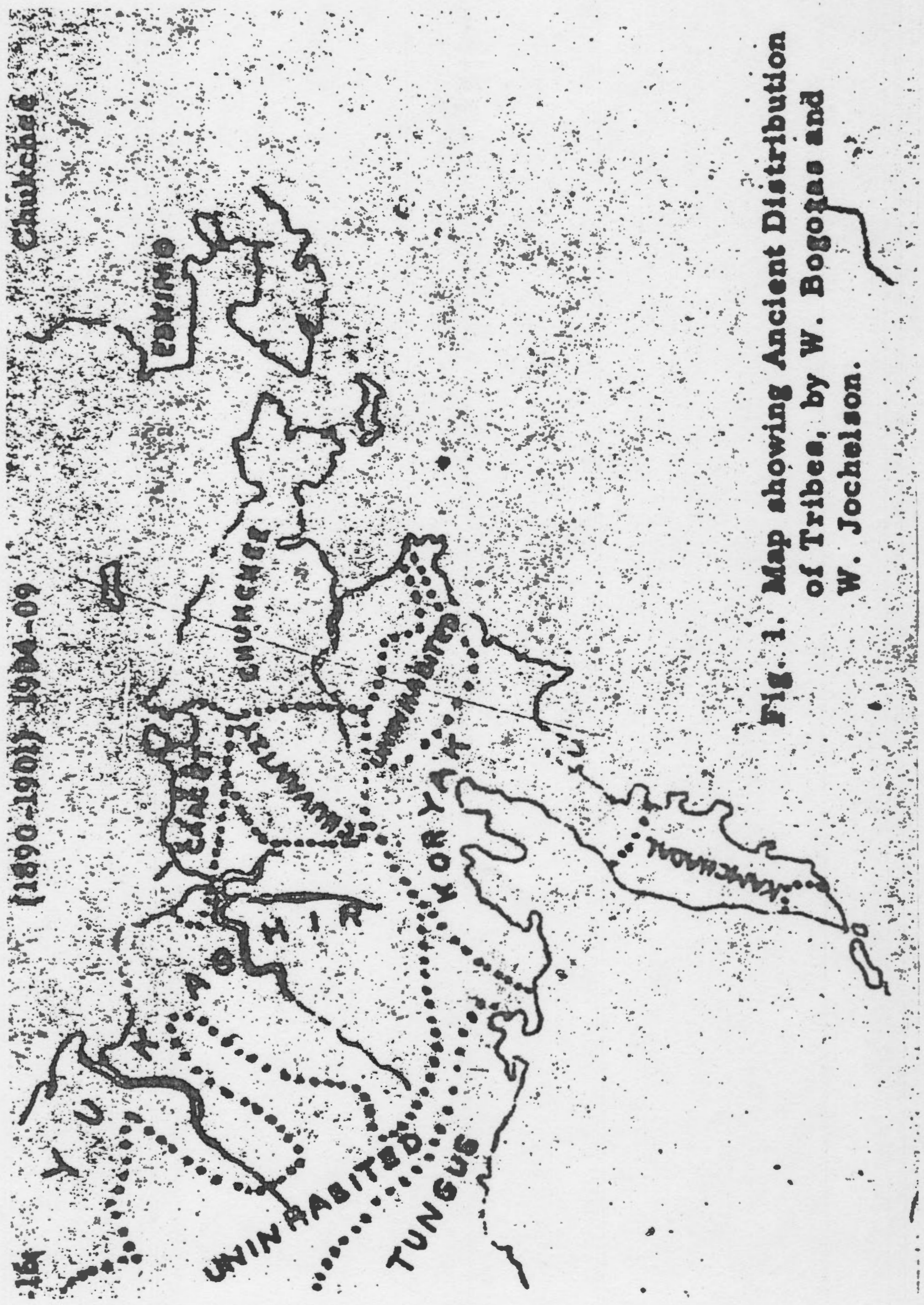




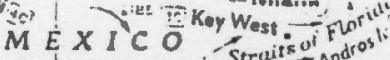

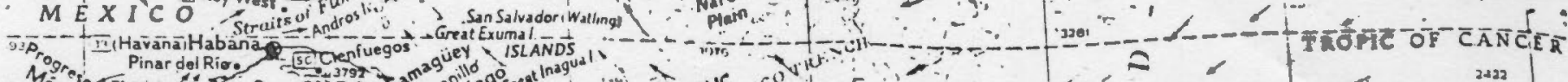

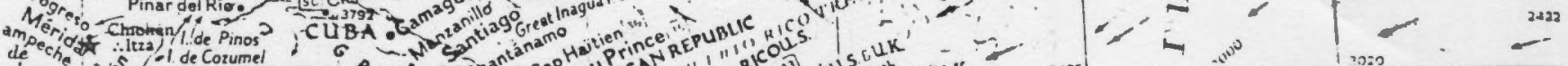

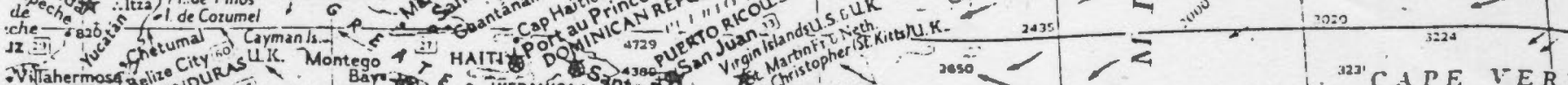

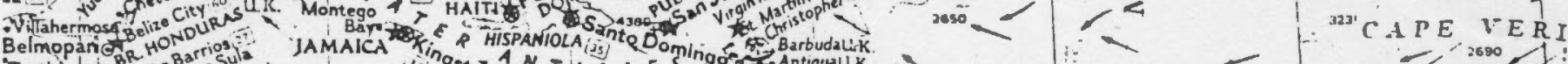
Tuxtlat. L 305. D. TP.5

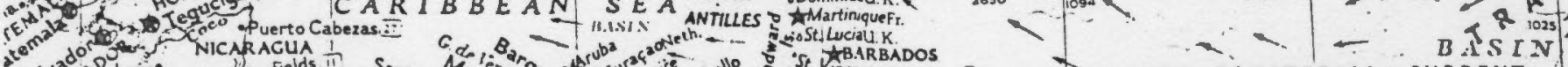

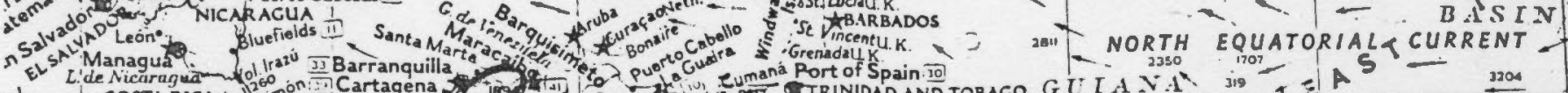

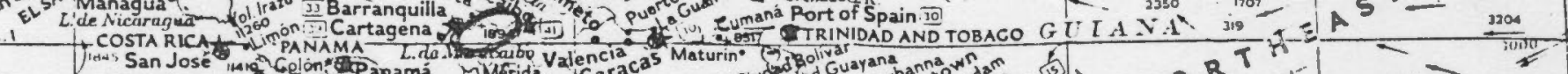

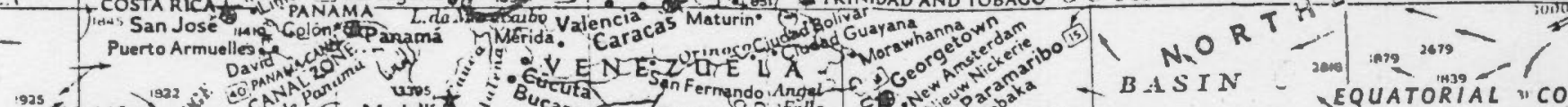

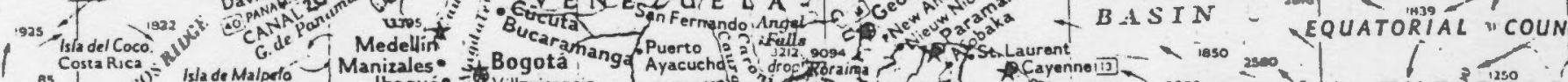

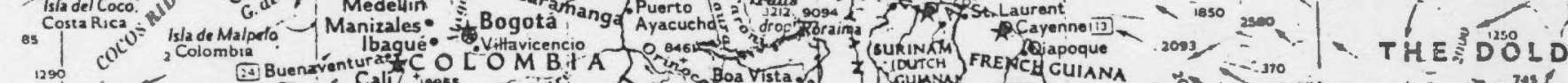

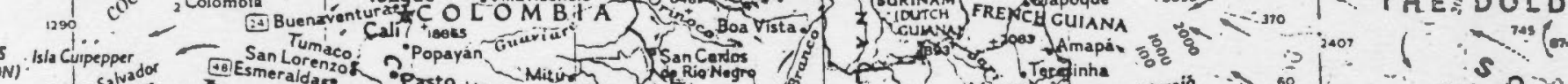
w)

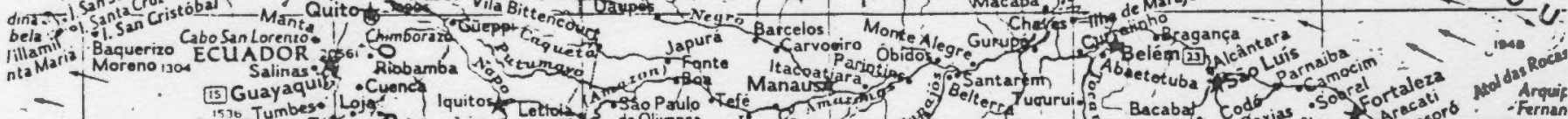

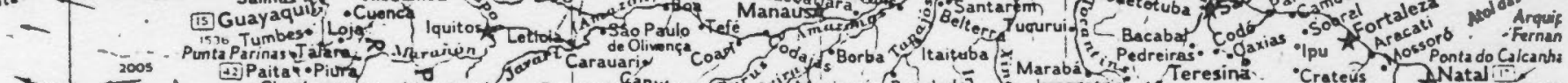

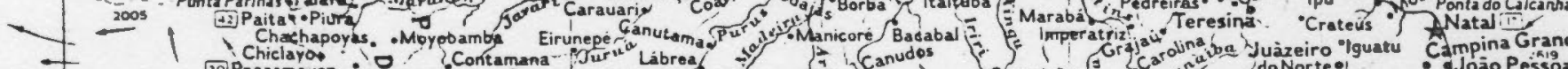

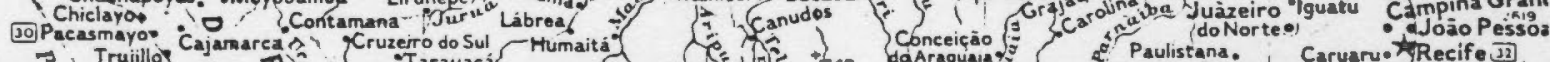

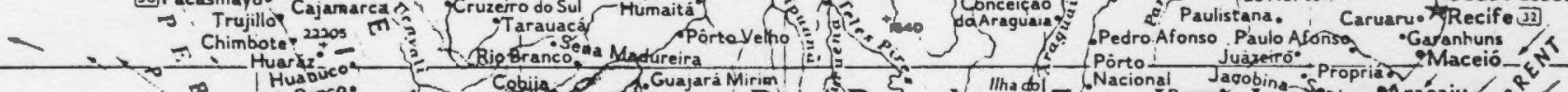

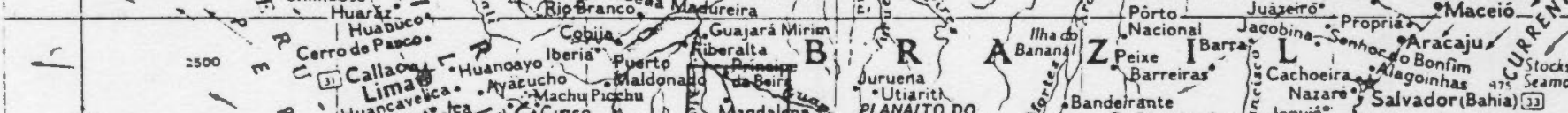

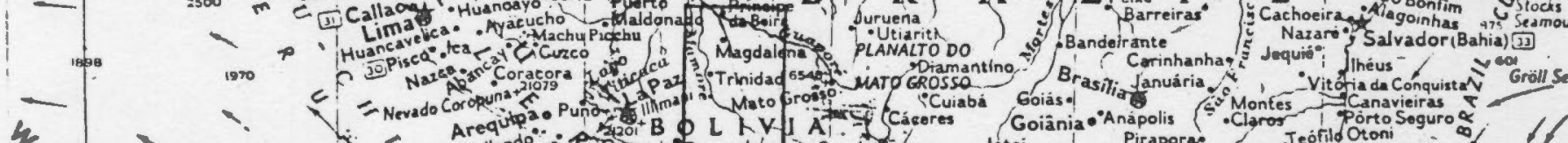

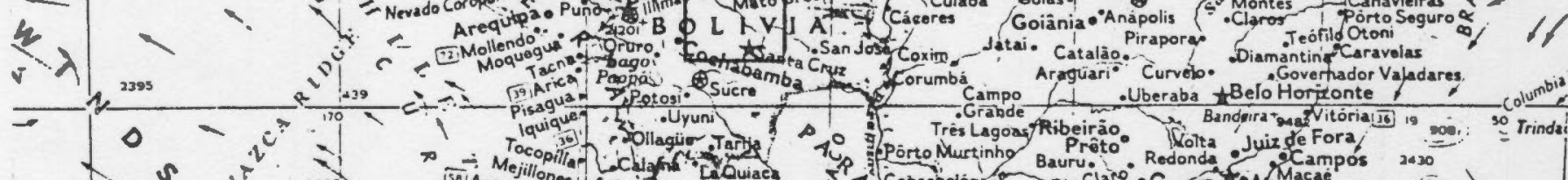

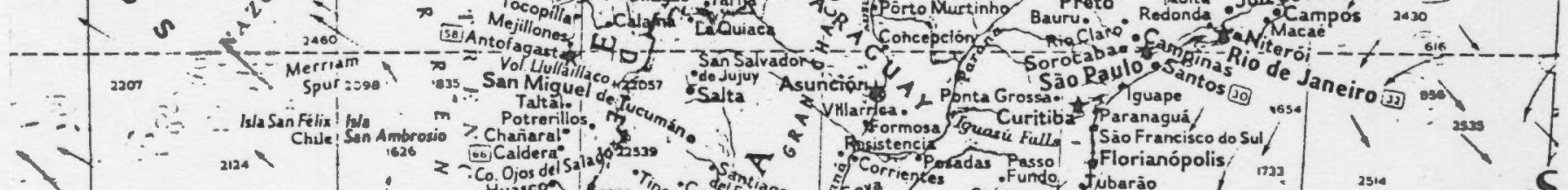

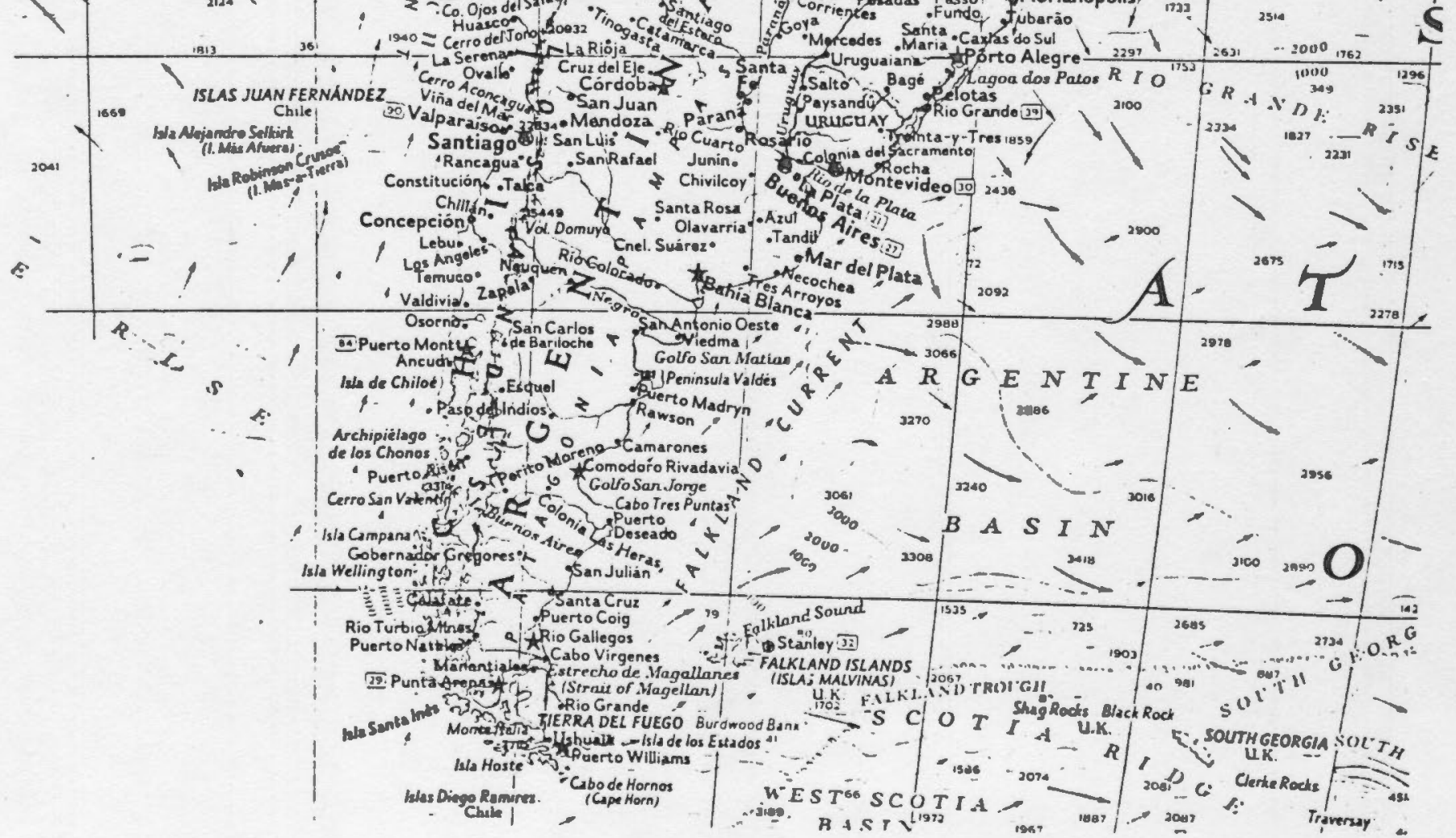


25: Pittier $-\mathbf{- 6 2 8}$

(No arte) 1912

Cuns

116, 101, 102

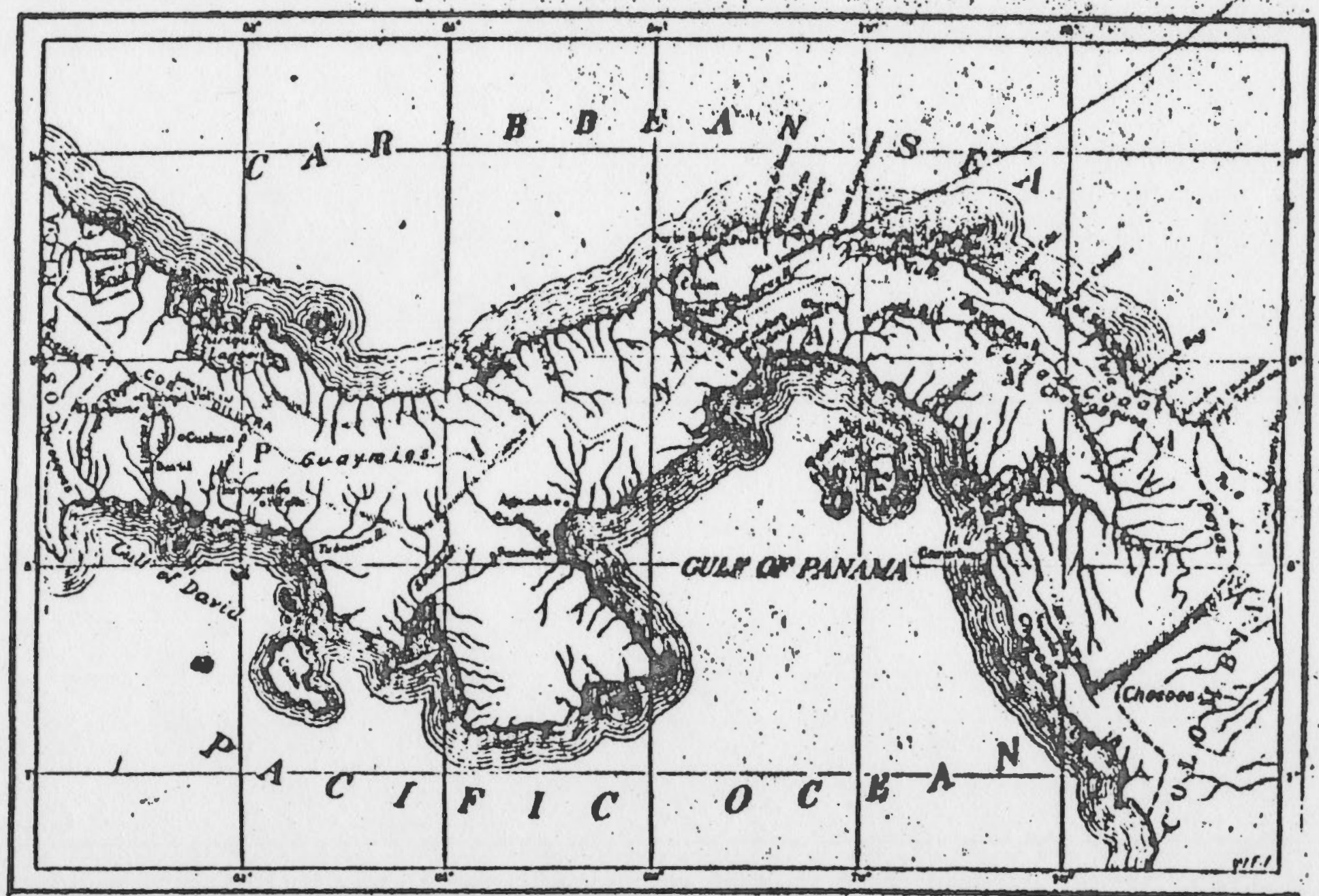

Sketch Map of Panama, Showing General Features and Present Location of Aboriginel; Tribes 


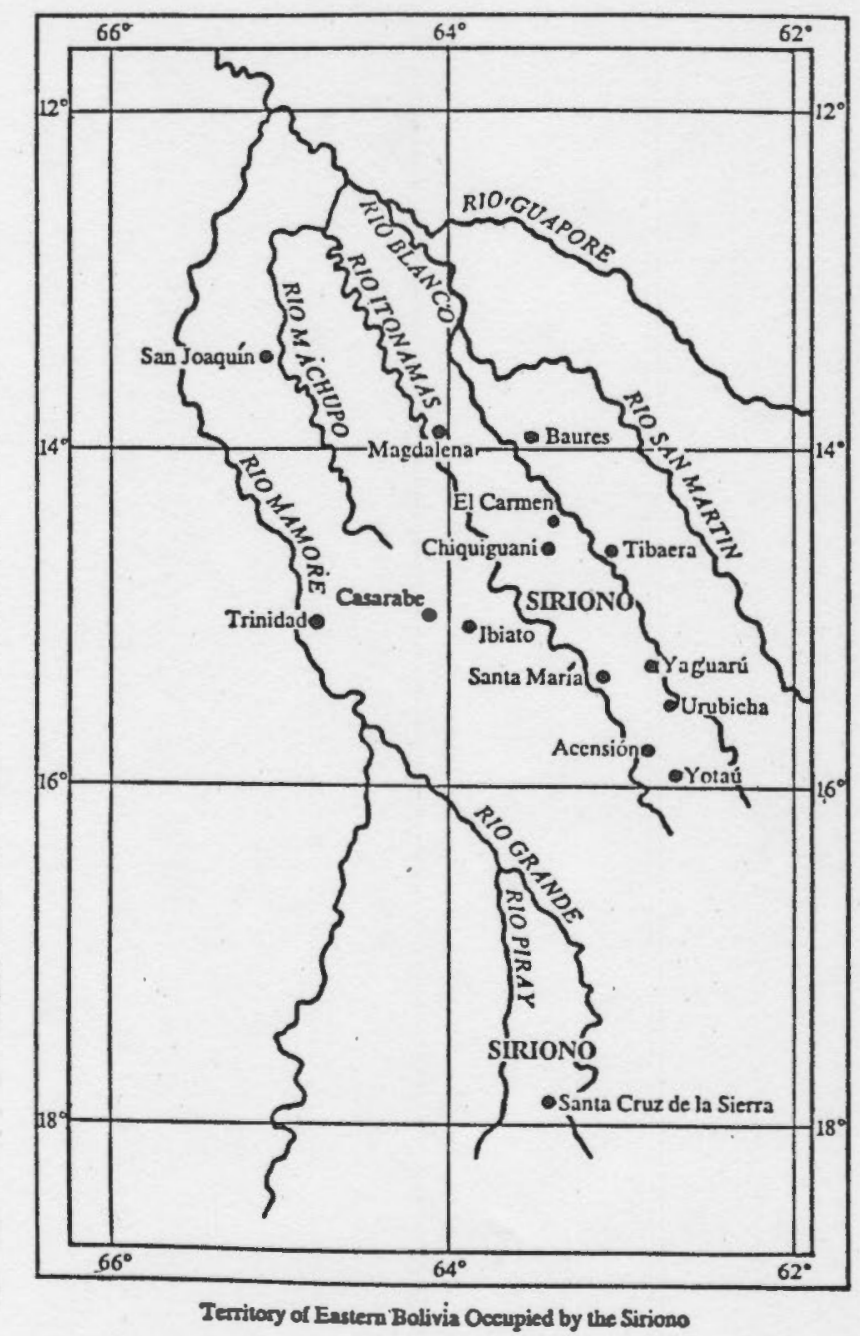




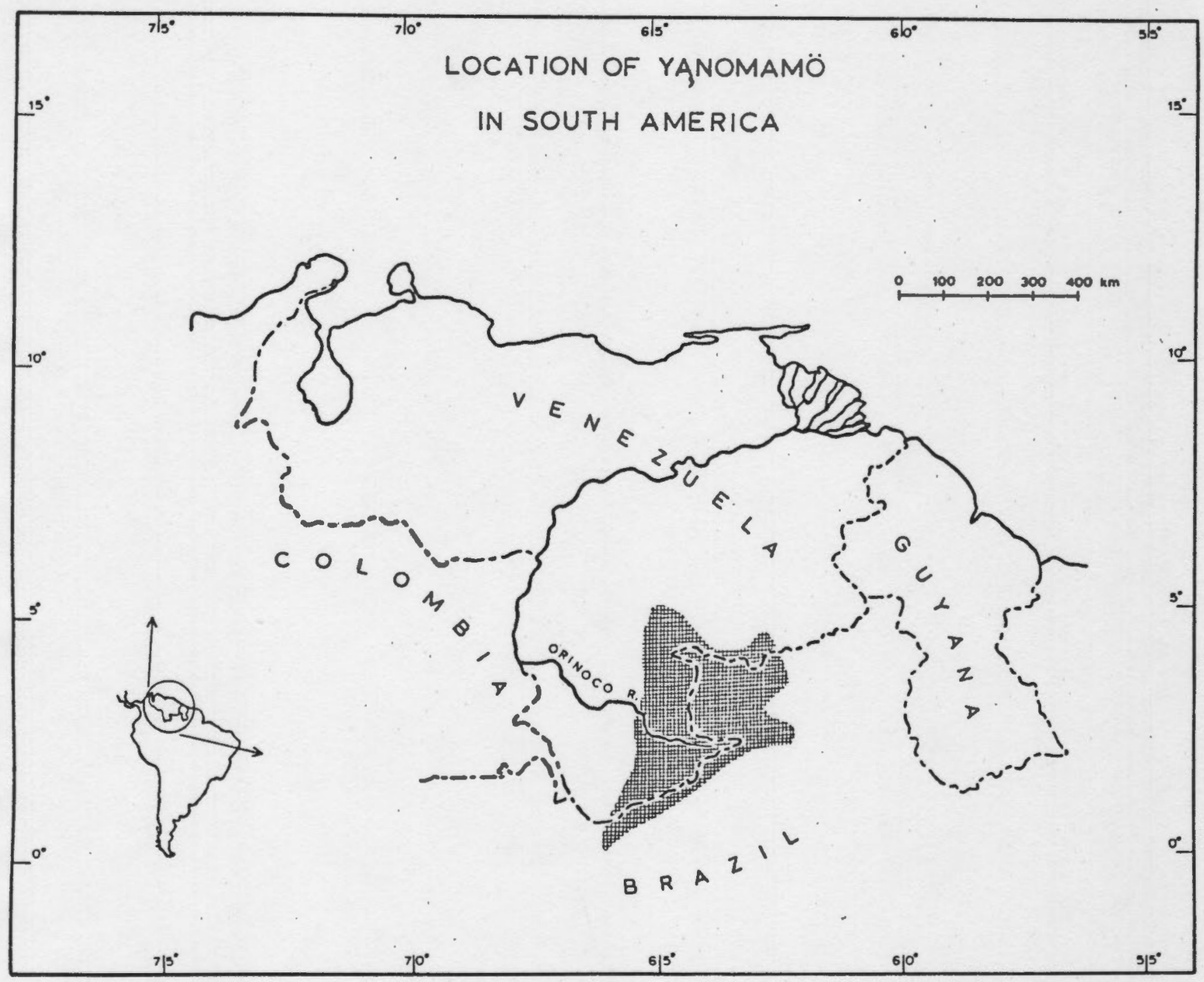

